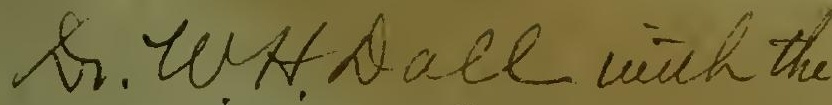

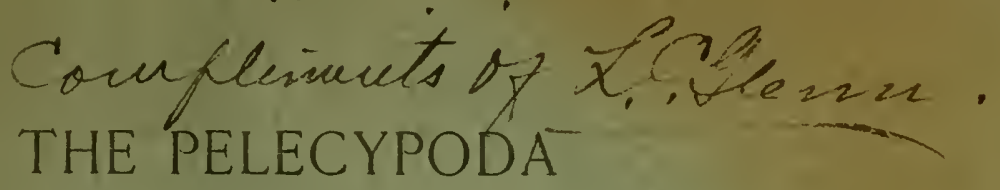

OF

\section{THE MIOCENE OF MARYLAND}

\author{
A DISSERTATION \\ PRESENTED TO THE BOARD OF UNIVERSITY STUDIES \\ OF THE JOHNS HOPKINS UNIVERSITY FOR THE \\ DEGREE OF DOCTOR OF PHILOSOPHY
}

BY

LEONIDAS CHALMERS GLENN

I899

BALTIMORE, MD.

DECEMBER, 1904 



\title{
THE PELECYPODA
}

$\mathrm{OF}$

\section{THE MIOCENE OF MARYLAND}

\author{
A DISSERTATION \\ PRESENTED TO THE BOARD OF UNIVERSITY STUDIES \\ OF THE JOHNS HOPKINS UNIVERSITY FOR THE \\ DEGREE OF DOCTOR OF PHILOSOPHY
}

BY

LEONIDAS CHALMERS GLENN

I899

BALTIMORE, MD.

DECEMBER, 1904 


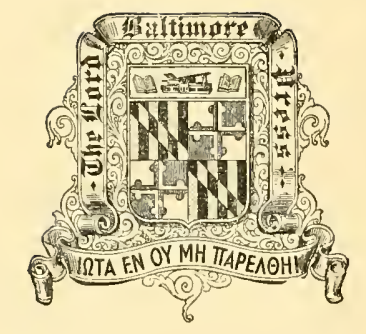

Ebe Jriedentrafo Company BALTIMORE, MD., L. S. A. 


\section{PREFACE}

The following study of the Pelecypoda of the Miocene of Maryland was undertaken at the suggestion of Dr. Wr. B. Clark, and was prosecuted in connection with the anthor's work on the stratigraphy and areal distribution of the Miocene of Maryland under the auspices of the Maryland Geological Siurvey. The summer of 1898 and a part of that of 1899 were spent in the field studying the rarions formations of the Miocene and later overlying deposits and mapping their areal distribution. During this arcal field work the material for this paper was collected and the stratigraphic relationships of each bed collected from ascertained as exactly as was possible. Many points at which fossils were collected afforded excellent stratigraphic sections so that as a result of this combined stratigraphic and paleontologic work no doubt can be left as to either the lithological or faunal sequence.

Since the stratigraphic colmmn of the Atlantic Coast Miocene naturally exposed in Maryland is much longer than that of any otler State, and is usually so abundantly fossiliferons, it affords a most excellent opportmity for the study of paleontological problems. The present monograph is presented as a contribution toward such a study by furnishing the materials on which study must be based.

The classification adopted is that of Dr. WT. II. Dall as presented in various publications but most fully elaborated by him in Tolume III of the Transactions of the Wagner Free Institute of Science of Philadelphia.

The thanks of the author are primarily due to Dr. W. B. Clark, without whose aid as Director of the Maryland Geological Survey the work could never have been undertaken. Acknowledgments are also due to the authorities of Cornell University and of both the Academy of Natural Science and the Wagner Free Institute of Science of Philadelphia for the opportmity to stndy the collections in their charge and 
for the use of certain drawings of fossils belonging to the latter institution. and to 1)r. W. H. Dall. of the Smithsonian Institution, both for access so freely given at all times to the collections of the National Mnseum and especially for his frequent valuable personal assistance and suggestion. The anthor is, however, alone to be held responsible for the opinions expressed herein.

L. C. Glens.

February s, 1904. 


\section{Class PELECYPODA. \\ Order TELEODESMACEA. \\ Superfamily ADESMACEA. \\ Family PHOLADID $Æ$. \\ Subfamily PHOLADINÆ. \\ Genus PHOLAS (Linné) Lamarck. \\ Subgenus THOVANA Gray. \\ Pholas (Thovana) producta Conrad. \\ Plate LXY Fig. 1.}

Pholus oblongata Tuomey and Holmes, 1856, Pleiocene Fossils of South Carolina, p. 103, pl. xxir, fig. 5.

Not Pholus oblongate Say.

Pholas producta Conrad, 1863, Proc. Acad. Nat. Sci. Phila., vol. xiv, p. 571.

Pholas producta Meek, 1864, Miocene Check List, Smith. Misc. Coll. (183), p. I2.

Pholas (Thovana) producta Dall, 189s, Trans. Waguer Free Inst. Sci., vol. ii, pt. iv, p. 815 .

Description.--"Shell oblong-ovate, inflated, transversely and longitudinally striated; striæ muricated, and elevated on the buccal side into ribs; buccal margin acutely rounded; anal margin compressed; dorsal margin anteriorly reflexed, forming a cavity; hinge callous, minutely striated transversely and longitudinally, and with about twelve cells." Tuomey and Holmes, 1856.

Occurrence.-Choptank Formation. Greensboro.

Collection.-Maryland Geological Survey.

Genus BARNEA (Leach MS.) Risso.

Subgenus SCOBINA Bayle.

Barnea (Scobina) arcuata (Conrad).

Plate LXV, Figs. 2, 3.

Pholas arcuata Conrad, 1841, Fossils of the Medial Tertiary, p. 3 of cover of No. 2. Pholas acuminata Conrad, 1845, Fossils of the Medial Tertiary, p. 77, pl. xliv, fig. 2. 
Pholas arcuata Conrad, 1863, Proc. Acad. Nat. Sci. Phila., vol, xiv, p. 571.

Pholas arcuctu Meek, 1S64, Miocene Check List, Smith. Misc. Coll. (183), p. 12.

Barnea (Scobina) arcuta Dall, 1s9s, Trans. Wagner Free Inst. Sci.; vol. iii, pt. iv, p. $\$ 16$.

Description.- "Shell oblong-ovate, with numerous ribs, elevated on the posterior side, and concentric wrinkled striæ, lamelliform on the anterior side; ribs squamose; base arcuated." Conrad, $18+1$.

This species differs from $P$. costata found so abundantly at Cornfield Harbor by being smaller, by having a longer umbonal reflection, and by being thicker and stronger. We have only a few broken valves.

Occurrence.-St. Mari's Formation. St. Mary's River.

Collection.-Maryland Geological Survey.

Genus MARTESIA Leach.

Section ASPIDOPHOLAS Fischer.

Martesia ovalis (Say).

Plate LXV, Figs. 4, 5, 6, 7, 8, 9.

Pholas ovalis Say, 18:20, Amer. Jour. Sci., vol. ii, p. 39.

Martesia (?) ovalis Dall, 1898, Trans. Wagner Free Inst. Sci., vol. iii, pt. iv, p. 820, pl. $x x x v i$, fig. 5 .

Description.—- "Tube equal, entire and rounded at base, and gradually attenuated towards the anterior termination. Shell subovate, dehiscent; valves with crowded, acute, elevated, transverse lines, somewhat decussate with longituaiinal slightly indented ones, a more conspicuous longitudinal indented line before the middle, posterior basal margin smooth; within equal, the posterior basal margin distinguished by a slight undulation." Say, 1820 .

Shell small, oval, elevated, thin, and fragile; a radial furrow extends obliquely across the shell from the beak to a point on the rentral margin slightly posterior to the middle, from this point a fine curved line extends diagonally forward and upward to the upper part of the anterior margin, thus dividing the surface into three portions, the anterior one being smooth, extremely thin and usually entirely broken off, the middle one being covered with fine, close, distinct, minutely crimped lamellæ running parallel to the curved line, bounding them anteriorly; the posterior portion with only rather coarse, irregular, concentric 
growth lines: umbonal reflection small, heary, standing almost rertically and curved posteriorly: within, chondrophore long, curred, narrow; posterior ligament area distinct, elongated, oval; median furrow showing as a slight ridge: umbonal area corered by a large, elongated oral or hour-glass shaped protoplax extending forward to below the middle of the anterior margin, backward nearly to the ends of the valves and corering a third of the side of the shell, being sometimes laterally contracted into a somewhat hour-glass outline: shell enclosed in a calcareons tube or siphonoplax lining the lurrow, thin anteriorly, thickened and contracted posteriorly: other accessory plates absent.

This interesting little shell is found often riddling the ralres of Melina maxillata. There can be no doubt of its identity with Say's species. M. rhomboidea H. C. Lea is, as remarlied by him in describing it, not just identical with $M$. ovalis, although the differences are slight and may not be of specific value,-still it is thought best not to unite them without examining a series of specimens of Lea's species.

Length, $16 \mathrm{~mm}$.; height, $10 \mathrm{~mm}$; d diameter, $5.5 \mathrm{~mm}$.

Occurrence.-St. Mani's Formatrox. Cote Point, St. Mary's River. Choptank Fommation. Jones Wharf, Pawpaw Point, St. Leonard Creek, Governor Run (lower bed). Cordota. Calivert Fonalitiox. Plum Point, White's Isanding, Reeds.

Collections.-Waryland Geological Surrey, Johns Hoplins University, U. S. National Museum.

\section{Superfamily MYACEA. \\ Family SAXICAVIDÆ. \\ Genus PANOPEA Ménard. \\ Panofea whitfeled Dall. \\ Plate JAT, Fig. 10.}

Pemopere Goldfussii Whitfield, 1894, Mon. xxiv, U. S. Geol. Survey, p. 89, pl. xri, figs. $9-13$.

Not Panopea Goldfussii Wagner, 1s:35.

Panopea Thitfeldi Dall, 1s9s, Trans. Wagner Free Inst. Sci., vol. iii, pt. ir, 1. s:?!.

Description.-Shell elongate-orate; beaks approximate. not prominent; anterior and posterior portions of the ralres almost equal: ante- 
rior portion not or but slightly expanded; posterior not or but slightly contracted and produced; surface with irregular, concentric undulations, more or less strongly marked and sometimes lamellar.

It differ's from $P$. goldfussii Wagner in being more equilateral, less expanded anteriorly and less contracted and produced posteriorly.

Length, $90 \mathrm{~mm}$.; height, $51 \mathrm{~mm}$; diameter, $8 \mathrm{~mm}$.

Occurrence-CHoptaxk Fonutiox. Governor Run (lower bed). Calvert Formatiox. Plum Point. Lyon's Creck, White's Landing, Tye Mills, Fairhaven, New Town (?).

Collections.-Maryland Geological Survey, Johns Hopkins University, U. S. National Musenm.

\section{Panopel Goldfussir Wagner.}

\section{Plate LXVI, Fig. 1.}

Panoper Goldfussii Wagner, 1539, Jour. Acad. Nat. Sci. Phila., vol. viii, 1st ser., 1). 5:, pl. i, tig. 3. Probably published privately in 1538.

Penopee porrecta Conlad, 184:, Fossils of the Medial Tertiary, p. 71, pl. xli, fig. 2. Glycimeris Goldfussii Conrad, 1563, Proc. Acad. Nat. Sci. Phila., rol. xir, p. 571.

Punoper Goldfussii Meek, 1864, Miocene Check List, Smith. Misc. Coll. (1S3), p. 12. Punopua porvectu Meek, 1s64, Miocene Check List, Smith. Misc. Coll. (183), p. 12. I'unoper Goldjussii Dall, 1s98, Trans. Wagner Free Inst. Sci., vol. iii, pt. iv. p. 829.

Description._."Shell oblong, subovate, ventricose; disks with concentric, unequal, shallow grooves; lines of growth coarse and prominent; anterior extremity slightly gaping; anterior margin rounded, anterior dorsal margin elevated; posterior side narrowed, somewhat produced, not reflected; posterior dorsal margin nearly rectilinear; cardinal teeth obliquely compressed, united at base to the nympha, short and not very prominent." Wagner, 1839 .

Length, $117 \mathrm{~mm}$; height, is mm.; diameter, $21 \mathrm{~mm}$.

Occurrence.-St. Mary's Formation. Cove Point, St. Mary's River. Choptank Formation. Governor Run (lower bed), Jones Wharf, Pawpaw Point. Calvert Foramion. Plum Point, Wye Mills, New Town (?).

Collections.-Maryland Ceological Survey, Johns Hopkins University, U. S. National Museum. 


\section{Panopea americana Comrad.}

Plate LXVI, Fig. 2.

Panopen thericuna Conrad, 1838, Fossıls of the Medial Tertiary, p.4, pl. ii, fig. 1. Glycimeris Americana Conrad, 1868, Proc. Acad. Nat. Sci. Phila., vol. xiv, p. $5 i 1$. Panopca Imericana Meek, 1s64, Miocene Clieck Jist, Smith. Misc. Coll. (18:3), p. 12. Panopea americana Dall, 1s9s, Trans. Wagner Free Inst. Sci., vol. iii, pt. iv, l. $\$ 30$.

Description._" Shell rhomboidal, flexuous, profoundly gaping at both extremities; surface undulate with coarse lines of growth; anterior margin obliquely truncated, nearly parallel with the posterior margin, which is also oblique and truncated; basal margin contracted in the middle; cardinal process very prominent and slender; nympha profound and very thick, its upper surface transversely striated; right valve with a wide and profound cardinal fosset." Conrad, 1838.

This species is very abundant, large, and well preserved in the Choptank formation.

Length, $190 \mathrm{~mm}$.; width, $102 \mathrm{~mm}$.; diameter, $34 \mathrm{~mm}$.

Occurrence.-Сhорталк Fonmation. Governor Run (upper and lower beds), 2 miles south of Governor Run (upper and lower beds), Flag Pond, St. Leonard Creek, Jones Wharf, Turner, Pawpaw Point, Peach Blossom Creek, Cordova, Greensboro. Calvert Formation. 3 miles south of Chesapeake Beach, Reeds, Wye Mills, Lyon's Creek.

Collections.-Maryland Geological Survey, Johns Hopkins University.

Genus SAXICAVA Fleuriau de Bellevue.

Saxicava Arictica (Linné).

Plate LXVI, Figs. 3, 4, 5, 6.

Mya aretica Linné, 176r, Syst. Nat., 12th Edit., p. 1113.

Mya arctira Fabricius, 1780, Fauna Grönlandica, p. 407.

Saxicuet distorta Say, 18:2:, Jour. Acad. Nat. Sci. Phila., vol. ii, 1st ser., p. 318.

Saxicum bilincata Conrad, 1S3s, Fossils of the Medial Tertiary, p. 18, pl. x, fig. $t$. Saxicave distortu Gould, 1841, luvert. Mass., P. 61, fig. 40.

Saxicam bilinecuta Conrad, 1863, Proc. Acad. Nat. Sci. Pbila., vol. xiv, p. 571.

Saxiraza bilineata Meek, 1864, Miocene Check List, Smith. Mise. Coll. (1\$3), p. 12. Saxicara insite Conrad, 1869, Amer. Jour. Conch., vol. v, 1'. 40.

Saxicura incita Conrad, 1869, Amer. Jour. Conch., vol. v, p. 101.

Suxicare aretica Gould (Binney's), 18\%0, Invert. Mass., p. S9.

Suxicume uretice Dall, 1898, Trans. Wagner Free Inst. sci., vol. iii, pt. iv, p. 834 . 
Description.-This shell varies extremely according to age and position and has received many names; for much fuller synonymy see Binney and Dall (cit. supra).

As most frequently found in Maryland the shell is roughly quadrilateral in outline; inequivalve, the right valve overlapping; beak nearly terminal; from it two ridges extend backward, one near the superior dorsal margin and the other, usually more prominent, to the posterior basal angle; exterior surface irregularly undulated and coarsely marked by lines of growth; anterior an'? posterior margins often almost squarely truncated; anterior basal margin at times contracted; teeth obsolete or at times one in either valve.

Instead of being quadrilateral, the outline may be very greatly modified by the production or curving of some portion of the margin. The ridges running back from the beak are perhaps the most constant character.

Length, $19 \mathrm{~mm}$; height, $9 \mathrm{~mm}$.; diameter, $5 \mathrm{~mm}$.

Occurrence.-St. Mary's Formation. Cove Point, St. Mary's River. Choptank Formation. Governor Run (upper and lower beds), 2 miles south of Governor Run (upper and lower beds), Flag Pond, Jones Wharf, Turner, Pawpaw Point, St. Leonard Creek, Dover Bridge, Greensboro. Calvert Formation. Chesapeake Beach, 3 miles south of Chesapeake Beach, Plum Point, White's Landing, 3 miles west of Centerville.

Collections.-Maryland Geological Survey, Johns Hopkins University, U. S. National Museum.

\section{Family CORBULIDÆ.}

Genus CORBULA (Bruguière) Lamarck.

Section CORBULA ss.

Corbula idonea Conrad.

Plate LXVII, Figs. 1, 2, 3.

Corbula idonea Conrad, 1833, Amer. Jour. Sci., vol, xxiii, p. 341.

Corbula idonea Conrad, 183s, Fossils of the Medial Tertiary, p. 6, pl. $x$, fig. 6 .

Corbula idonea Conrad, 1863, Proc. Acad. Nat. Sci. Phila,, vol. xiv, p. 5 r2.

Corbula idonea Meek, 1864, Miocene Check List, Smith. Misc. Coll. (183), p. 12.

Corbula idoned Whitfield, 1894, Mon. xxiv, U. S. Geol. survey, p. 88, pl. xr, fig. 20.

Corbula (Corbula) idonea Dall, 1898, Trans. Wagner Free Inst. Sci., vol. iii, pt. iv, p. 852. 
Description.-_ "Shell subtriangular, convex, thick, obscurely undulated; with a fold on the posterior submargin and the extremity angular; basal margin acute: cardinal tooth very thick and elevated. Length, one inch." Conrar, 1833.

Surface of left valve with obsolete concentric undulations, angular posteriorly; right valve with irregular, concentric undulations, beak more prominent and strongly curved than in lower valve; posterior submargin ridged, tooth massive.

Length, $34 \mathrm{~mm}$; height, $29 \mathrm{~mm}$; diameter, $13 \mathrm{~mm}$.

Occurrence.-Сhорталк Fonmation. Governor Run, 2 miles south of Governor Run, Flag Pond, Jones Wharf, Cuckold Creek, 'Turner, Pawpaw Point, Dover Bridge, Peach Blossom Creek, Trappe Landing, Cordova, Greensboro, Skipton. Calvert Formation. Chesapeake Beach, 3 miles south of Chesapeake Beach, Plum Point, Reeds.

Collections,-Maryland Geological Survey, Johns Hopkins University.

Section ALOIDIS Megerle von Mühlfeld.

Corbula elevata Comrad.

Plate LIVII, Figs. 4, 5.

Corbula elevata Conrad, 1838, Fossils of the Medial Tertiary, p. 7, pl. iv, tig. :3. Corbula clevata Conrad, 1868 , Proc. Acad. Nat. Sci. Phila., vol. xiv, p. 57:.

Corbula elerata Meek, 1864 , Miocene Check List, Smith. Misc. Coll. (183), p. 12.

Corbula enrta Conrad, 1867, Amer. Jour. Conch., vol. iil, 1) 269, pl. xxi, figs. 6-8.

Corbulu (Aloidis) elevata Dall, 1898, Trans. Wagner Free Inst. Sci., vol. iij, pt. iv, p. 8.5.

Description._" Shell triangular, equilateral, height greater than the length; inferior valve ventricose, with regular numerous concentric impressed lines, which disappear on the posterior slope; umbo profoundly elevated; posterior slope with an obtuse furrow descending from the beak; extremity narrowed, slightly emarginate." Conrad, 1838.

Length, $12 \mathrm{~mm}$; height, $12.5 \mathrm{~mm}$; diameter, $4.5 \mathrm{~mm}$.

Occurrence--CAlvert Formatiox. Fairhaven, Chesapeake Beach, 3 miles south of Chesapeake Beach, Plum Point, Lyon's Creek, 'Truman's Wharf, White's Landing, Reeds, 3 miles west of Oenterville.

Collections.-Maryland Geological Survey, Johns Hopkins University, U. S. National Museum. 
Section CUNEOCORBULA Cossmann.

CORBULA IN.EQUALIS Say.

Plate LIVII, Figs. 6, \%, 8, 9, 10, 11, 12, 13, 14.

Corbula inrequale Say, 1824, Jour. Acad. Nat. Sci. Phila., vol. iv, 1st ser., p. 158, pl. xiii, fig. 2:-not of Conrad, 1838, Fossils of the Medial Tertiary, p. 6.

Corbula euneata Conrad, 1938, Fossils of the Medial Tertiary, p. 5 (excl. diag.), pl. iii, tig. :2.

Corbule inceque Tuomey and Holmes, 1856, Pleiocene Fossils of South Carolina, p. $76, \mathrm{pl} . \mathrm{xx}$, fig. 12.

Corbula incequalis Meek, 1864, Miocene Check List, Smith. Misc. Coll. (183), p. 12.

Corbula subcontracte Whitfield, 1894, Mon. xxiv, U. S. Geol. Survey, p. 58 , pl. xv, figs. $1 \mathrm{l}-14$.

Corbule cuneuta Harris, 1896, Bull. Amer. Pal., No. 5, pp. 329, 346, pl. xiii, fig. 2;not of Say, 1824.

? Corbutu (Cuneocorbuta) Whitfleldi Dall, is9s, Trans. Wagner Free Inst. Sci., vol. jii, pt. iv, p. $\$ 49$, pl. xxxvi, fig. 18.

Corbuta (Cuneocorbula) incqualis Dall, 1898, Trans. Wagner Free Inst. Sci., vol, iii, pt. iv, p. 853.

Corbula (Cuneocorbulu) subcontructa Dall, 1898, Trans. Wagner Free Inst. Sci., vol. iii, pt. iv, p. 854 .

Description._"Shell convex, transversely ovate-trigonal, rough, with unequal coarse wrinkles: anterior margin with a very acute but short rostrum at its inferior termination, separated from the disk by an acute line: base rounded and a little contracted near the anterior angle: umbones not prominent." Say, 1824.

This species is somewhat rariable in size, outline, thickness of shell, and strength of ornamentation. Specimens from Church Hill are quite small and agree with the types of $C$. subcontracta. The upper posterior angle in Thitfield's fig. 11 is not characteristic, his fig. 12 is much more typical. Between the larger Church Hill specimens, some from Plum Point, and specimens of $C$. whitfieldi, there seems to be very little, if any, essential difference. Specimens from the Jones Wharf horizon are often more finely striated than those from the Calvert formation, while those from the St. Mary's formation are largest, thickest and have the most rounded base. All agree in having rather coarse. irregular, concentric undulations.

Length, $10.5 \mathrm{~mm}$; height, $7 \mathrm{~mm}$; diameter, $2.6 \mathrm{~mm}$. -St. Mary's River specimen.

Occurrence.-St. Marr's Formatiox. Cove Point, Langley's Bluff. 
St. Mary's River. Choptank Formation. Governor Run, 2 miles south of Governor Run, Flag Pond, Jones Wharf, Turner, Pawpaw Point, Dover Bridge, Peach Blossom Creek, Trappe Landing, Cordova. Calvert Formation. Fairhaven, Chesapeake Beach, 3 miles south of Chesapeake Beach, Plum Point, Lyon's Creek, White's Landing, Truman's Wharf, Wye Mills, 3 miles west of Centerville, Church Hill.

Collections.-Maryland Geological Survey, Johns Hoplins University, U. S. National Museum.

\section{Corbula cuneata Say.}

Plate I.IVII, Figs. 15, 16, 1\%, 18, 19.

Corbula cuneata say, 1s24, Jour. Acad. Nat. Sci. Phila., vol. iv, 1st ser., p. 152, pl. xỉii, fig. 3.

Corbula incequale Conrad, 1838, Fossils of the Medial Tertiary, p. 6, pl. iil, tig. 3, (left hand one), (diagn. and remarlis excluded.)

Corbula cuneata Meek, 1864, Miocene Check List, Smith. Nlisc. Coll. (153), p. 12.

Corbula (Cuncocorbula) cuncata Dall, 189s, Trans. Wagner Free Inst. Sci., vol. iii, pt. iv, p. 854 .

Jescription.- "Shell transversely ovate-trigonal, acutely angulated or somewhat rostrated before, and depressed on the anterior slope, which is separated from the disk by a subacute line: surface of both valves similarly striate with equal, elevated, equidistant lines, forming grooves between them; the striæ on the smaller valve are rather more distant: umbones not prominent." Say, 1824.

It may be distinguished from $C$. incqualis by having striæ that are much finer and more close set, equal, and equidistant than in $C$. incequalis. It is also much less common. When found at all it is more commonly at the Jones Wharf horizon.

Length, $12 \mathrm{~mm}$; height, $7.5 \mathrm{~mm}$; diameter, $2.5 \mathrm{~mm}$.

Occurrence-ChOPTANK Formatiox. Governor Run, 2 miles south of Governor Run, Flag Pond, Jones Wharf, Pawpaw Point, Turner, Trappe Landing, Greensboro, Cordova. Calvert Cormation. Plum Point.

Collections.-Maryland Geological Survey, Jolns Hopkins University, U. S. National Museum. 
Family MYACID覀.

Genus MYA (Limé) Lanarck.

Mra pRoducta Conrad.

Plate LXVIII, Figs. 1a, 1b, 2.

Myu producta Conrad, 183י, Fossils of the Medial Tertiary, p. 1, pl, i, fig. 1.

Mya prelonga Conrad, 1842, Proc. Nat. Inst., Bull. ii, p. 185,-name only.

Iyu producta Conrad, 1863, Proc. Acad. Nat. Sci. Phila., vol, xir, p. 5\%?.

Mya producta Meek, 1864, Miocene Check List, Smith. Misc. Coll. (183), p. 12.

Mya productu Dall, 1898, Trans. Waguer Free Inst. Sci., vol. iii, pt. iv, p. 858.

Description.—“ Shell profoundly elongated, elliptical, flexuous; surface coarsely wrinkled; beaks prominent, flattened posterior to the middle; base emarginate, corresponding to the furrow on the disk; left valve with obsolete radiating striæ; cardinal tooth profoundly dilated." Conrad, 1838.

"This is a fine and remarkably elongated species, gaping at both extremities, and very rare."

We have but one imperfect valve.

Length, $123 \mathrm{~mm}$.; height, about $50 \mathrm{~mm}$.; diameter, $14 \mathrm{~mm}$.

Occurrence.-Choptank Foriatiox. Jones Wharf.

Collection.-Maryland Geological Survey.

Genus SPHENIA Turton.

Sphenia dubia (H. C. Lea).

Plate LXVIII, Figs. 3, 4, 5, 6.

Panopcea dubia H. C. Lea, 1845, Trans. Amer. Philos. Soc, vol. ix, p. 236, pl. xxxiv, tig. 9.

Glycimeris dubia Conrad, 1863, Proc. Acad. Nat. Sci. Phila., vol. xiv, p. 571.

Panopcea dubia Meek, 1864, Miocene Check List, Smith. Misc. Coll. (183), 1. 12.

Sphenia dubia Dall, 1898, Trans. Wagner Free Inst. Sci., vol. iii, pt. iv, p. 859.

Description.-_" Shell quadrately elliptical, transverse, inequilateral, posteriorly truncate, anteriorly rounded, somewhat inflated, rather thick, striate; striæ concentric, regular; basal margin straight; beaks prominent; nymphæ large, exserted, very long; hinge with a small fosset." Lea, 1845 . 
The shape is quite variable according to the conditions of growth; shell moderately or markedly convex, produced and truncated or attenuated posteriorly; strix not regular but somewhat irregular and changing into shallow undulations, those on the dorsal and posterior slopes meeting at nearly a right angle; left valve with a flat tooth internally smooth, externally slightly grooved and fitting into a well marked fosset in the right valve, which is bounded anteriorly by a slight ridge.

A remarkably fine large specimen from Jones Wharf measures in length, $18 \mathrm{~mm}$; height, $11 \mathrm{~mm}$.; diameter, $4 \mathrm{~mm}$.

Occurrence.-Choptank Formation. Governor Run, Jones Wharf, Pawpaw Point, Greensboro. Calvert Formatiox. Plum Point.

Collections.-Maryland Geologieal Survey, Johns Hopkins University.

Genus PARAMYA Conrad.

Paramya subovata Conrad.

Plate LXVIII, Figs. \%, 8 .

Myalina subovatu Conrad, 1845, Fossils of the Medial Tertiary, p. 65, pl. xxxvi, fig. 4.

Peremye subovetu Conrad, 1860, Proc. Acad. Nat. Sci. Phila., vol, xii, p. 232.

Purumea subouta Conrad, 1863, Proc. Acad. Nat. Sci. Phila., vol. xir, p. 5i:.

Paramya subovata Mcek, 1864, Miocene Check List, Smitlı. Misc. Coll. (153), 1. 12. Paramya suboruta Dall, 1889, Bull. xxxvii, U. S. Nat. Mus., p. ro.

Preramye subonate Dall, 1898, Trans. Wagner Free Inst. Sci., vol. iii, pt. iv, p. 861.

Description.- "Subovate, inequilateral, ventricose orer the umbonal slope, slightly flattened from beak to base; surface with irregular concentric lines; ligament and basal margins straight, parallel; a spoonshaped fosset in each valie, the lateral margins of which are carinated; fosset emarginate at base." Conrad, 1845.

Basal and ligament margins not parallel but divergent posteriorly. Quite rare.

Length, õ.5 mm.; height, $4 \mathrm{~mm}$.; diameter, $1 \mathrm{~mm}$.

Occurrence.-Сhoptank Foratition. 2 miles south of Governor Run, Jones Wharf. Calvert Foracation. Plum Point.

Collection.-Maryland Geological Survey. 


\section{Superfamily MACTRACEA. \\ Family MESODESMATIDÆ. \\ Subfamily MESODESMATINÆ. \\ Genus MESODESMA Deshayes. \\ MEsodesma MARIANA n. Sp. \\ Plate LXIX, Figs. 1, 2, 3.}

Description.- Shell ovate, depressed, inequilateral; anterior end much the longer; beak very low; anterior side straight; anterior end acutely rounded and much above the line of the base; base a regular curve continuous with curve of anterior end; posterior side and end bluntly curved, meeting the base at an angle on the line of the base; posterior adductor scar compact, oval; anterior scar elongated and largest below; pallial line distinct; pallial sinus moderately deep, rounded; exterior surface somewhat polished with some irregular fine concentric growth lines.

Length, $9.75 \mathrm{~mm}$; height, $6.5 \mathrm{~mm}$; diameter, $1.8 \mathrm{~mm}$.

Occurrence.-ST. Marr's Formatiox. Cove Point, St. Mary's River.

Collections.-Maryland Geological Survey. .Johns Hopkins University.

\section{Subfamily ERVILIINA.}

Genus ERVILIA Turton.

Ervilia planata Dall.

Plate J.IIX, Figs. 4, 5. 6.

Ervilia planata Dall, 1898, Trans. Wagner Free Inst. Sci., vol. iii, pt. iv, p. 915.

Description._"Shell small, subtriangular, flattened, smooth or obscurely concentrically ridged, stibequilateral; the beaks low. calyculate; the dorsal slopes slightly rounded, subequal; the base evenly arched, not projecting; hinge well dereloped, the marginal grooves in the right valve almost as long as the dorsal margins; pallial sinus small, rounded in front, falling considerably short of the vertical from the beaks. Lon. 3.25, alt. 2.25, diam. 1.5 mm." Dall, 1898.

Occurrence.-Calvert Formatiox. Church Hill.

Collection.-Maryland Geological Survey. 


\section{Family MACTRIDÆ.}

\section{Subfamily MACTRINÆ}

Genus MACTRA (L.) Lamarck.

mactra clatirodon Lea.

Plate LXIX, Figs. 7, 8, 9.

Muctre cluthodon Lea, 1833, Contrib. to Geology, p. 212, pl. vi, fig. 22:3.

Mactra subcuncate Conrad, 1838, Fossils of the Medial Tertiary, p. 28, pl. xv, fig. 3.

Mactru clathodon Dall, 1898, Trans. Wagner Free Inst. Sci., vol. iii, pt. iv, p. 892.

Description.- "Shell subtriangular, thin, inequilateral, obscurely and transversely striate; beaks somewhat pointed; lateral teeth crossed by equidistant minute striæ; excavation of the pallial impression small and rounded; anterior and posterior cicatrices scarcely visible; cavity of the shell somewhat deep; carity of the beaks rather deep." Lea, 1833.

Lea's type specimens are the young of the same species whose adult form Conrad later described as M. subcuneata.

Length, $33 \mathrm{~mm}$. ; height, $25 \mathrm{~mm}$.; diameter, $7 \mathrm{~mm}$.

Occurrence.-St. Mary's Formation. Cove Point, Langley's Bluff, St. Mary's River. Calvent Fonmation. Plum Point, 3 miles west of Centerville.

Collections.-Maryland Geological Survey, Johns Hopkins University. Genus SPISULA Gray.

Subgenus HEMIMACTRA Swainson.

Section MACTROMERIS Conrad.

Spisula (Hemintatra) delumbis (Conrad).

Plate LXIX, Fig. 10.

Mactra delumbis Conrad, 1832, Fossil Shells of the Tertiary, p. 26, pl. xi.

Mactra delmbis Conrad, 1838, Fossils of the Medial Tertiary, p. :27, pl, xv, fig. 1.

Ifuctru delumbis Conrad, 1863, Proc. Acad. Nat. Sci. Phila., vol, xiv, p. 572.

Muctra delumbis Meek, 1864, Miocene Check List, Smith. Misc. Coll. (183), p. 11.

Nactra Virginiune Conrad, 1867, Amer. Jour. Conch., vol. iii, pp. 188, 269, pl. xxii, fig. 4 .

Wactra (Schizodesma) delumbis Whitfield, 1894, Mon. xxiv, U. S. Geol. Survey, p. S2, pl, $\mathrm{xv}, \mathrm{fig} .10$.

Spisulu (Hemimuctre) delumbis Dall, 1898, Trans. Wagner Free Inst. Sci,, vol. iii, nt. iv, p. $89 \%$, pl. xxvii, ti 2.26 . 
Description.-." Suboval, thin and fragile, with a fold on the posterior submargin; umbo prominent; beaks nearly central, approximate; lunule much elongated, lanceolate, slightly impressed." Conrad, 1832.

Surface nearly smooth, teeth prominent, fosset large, pallial sinus acutely rounded, distinguished from $S$. marylandica by having but one elevated line on upper posterior slope. No specimens obtained were perfect enough to measure.

Occurrence.-St. Mary's Formation. St. Mary's River. Choptank Formation. Governor Run, Jones Wharf. Calvert Formation. Chesapeake Beach.

Collections.-Maryland Geological Survey, Johns Hoplkins University.

\section{Spisula (Hemimactra) matiylandica Dall. \\ Plate LXIX, Fig. 11.}

Spisula (Hemimuctra) marylundica Dall, 1898, Trans. Wagner Free Inst. sci., vol. iii, pt. iv, p. $89 \pi$, pl. xxviii, tig. ร.

Description.- "Shell large, suboval, thin, inflated, with a nearly smooth surface, marked chiefly by incremental and obsolete radiating lines; beaks high, subcentral, adjacent; anterior end excavated above, rounded in front, posterior sloping to a bluntly pointed end behind; anterior dorsal area smooth and deeply impressed; posterior area somewhat depressed, striated, flexuous, with three obscure, elevated lines, extending from the umbo to the margin outside of the area; base arcuate; pallial sinus rather narrow, extending nearly to the middle of the shell, bluntly pointed in front; hinge strong, with a large oblique chondrophore, very short, smooth lateral laminæ, and the anterior arm of the right cardinal tooth coalescent with the ventral lamina.

"This fine species is at once differentiated from $S$. delumbis by its more equilateral and inflated shell, and by having instead of only one three elevated lines radiating backward from the beak." Dall, 1898.

Length, $90 \mathrm{~mm}$.; height, $67 \mathrm{~mm}$.; diameter, $40 \mathrm{~mm}$. (Dall).

Occurrence.-St. Mary's Formation. St. Mary's River. Choptani Formation. Jones Wharf. Calnert Foniration. Plum Point.

Collections.-Maryland Geological Survey, U. S. National Museum. 


\section{Spisula (Heminactra) curtidexs Dall.}

Plate LXIX, Figs. 12, 13.

Syisula (Hemimactra) curtidens Dall, 1s!s, Trans. Wagner Frec Inst. Sci., vol. iii, pt. iv, p. 895 , pl. xxvii, figs. 2,24 .

Description._- Shell large, not heavy, subtrigonal, with low, narrow, rather pointed beaks, the anterior being markedly longer than the posterior end; surface smooth or striated by incremental lines, and near the base loy fine, obscure, irregular Jongitudinal wrinkles; valves moderated, inflated; anterior end produced, depressed abore, rounded in front; posterior end short, flattened in front of the beaks. posterior dorsal area impressed and bounded by a rounded ridge which extends from the beak to the margin; anterior dorsal area impressed, with a somewhat flexuous surface; hinge with a large but not projecting ehondrophore; in the right valve the dorsal laminæ are very short and smooth, the cardinal tooth quite compressed. Lon. (of young shell) 22, alt. 1\%, diam. about $9 \mathrm{~mm}$; but judging from the fragments found, the species reaches when adult a height and length of $90 \mathrm{~mm}$.

"This fine Spisula is sharply distinguished from any other American species by its high and triangular form, short, exeavated hinge-plate, and the inequilaterality of the shell." Dall, 1898.

Occurrence.-Choptank Forantiox. Dover Bridge (Dall). CaLvert Formation. Burch's (Dall).

Collection.-U. S. National Iuseum.

Spisula (Heminactra) subpoxderosa (d'Orbigny).

Plate LXX, Figs. 1, 2, 3. 4.

Wuctra ponderosa Conrad, 1850, Jour. Acad. Nat. Sci. Phila., vol. vi, 1st ser., p. :228, pl. x, fig. 5, -not of Eichwald, 1830, Nat. Skizze von Lith., p. $20 \%$.

Muctru ponderosa Conrad, 1858, Fossils of the Medial Tertiary, p. 25, pl. xir, tig. 1. Mactra subponderosa d Orbigny, 1552, Prod. Pal. Strat., vol. ii, p. 100.

Maction ponderosa Conrad, 186:3, Proc. Acad. Nat. Sci. P’hila., vol. xiv, p. 572.

Muctru ponderosu Meek, 1864, Miocene Check List, Smith. Misc. Coll. (18?), p. 11.

Whactrodesmu ponderosa Conrad, 1869, Amer. Jour. Conch., vol. iv, p. 24i.

Spisule (Hemimactre) subponderose Dall, 189s, Trans. Wagner Free Inst. sci., vol. iii, pt. iv, p. 899, pl, xxvii, figs. 3,16 .

Description. " Shell subtriangular, conrex, thick, concentrically undulated; anterior margin depressed, with an obtuse plication at the angle; beaks nearest the posterior margin. 
"Three and a quarter inches in length and four and a quarter inches in breadth. The cardinal pit is large, thick, and subcordate, and the lateral teeth are short and very robust; when the valves are closed, the depression on the anterior slope forms a slightly concave area." Conrad, 1830.

Length, $108 \mathrm{~mm}$; height, $86 \mathrm{~mm}$.; diameter, $2 \mathrm{Smm}$.

Occurrence.-St. Mary's Formation. Cove Point, St. Mary's River.

Collections.-Maryland Geological Survey, Johns Hopkins University, U. S. National Museum.

\section{Spisula (Hemimactra) confraga (Conrad). Plate LXX, Figs. 5a, 5b.}

Mactra confraga Conrad, 1833, Amer. Jour. Sci., vol. xxiii, p. 340, not spelled confragosa.

Mectra fragosa Conrad, 1838, Fossils of the Medial Tertiary, p. 26, pl. xiv, fig. 2. Mactra incrassata Conrad, 1s38, Fossils of the Medial Tertiary, p. 24, pl. xiii, fig. 2. Mesodesma confraga Conrad, 1863, Proc. Acad. Nat. Sci. Phila., vol. xir, p. 574. Mesodesma incrassata Conrad, 1863, Proc. Acad. Nat. Sci. Phila., vol. xiv, p. 574. Spisula confragosa Meek, 1861, Miocene Check List, Smitl. Misc. Coll. (183), p. 11. Spisula confragosa Dall, 1898, Traus. Wagner Free Inst. Sci., vol. iii, pt, iv, p. 900.

Description.- "Shell subtriangular; narrow, somewhat thick, with coarse concentric lines; umbo oblique; beaks a little elevated, approximate; posterior side longer and less obtuse than the anterior; fosset large cordate, oblique; lateral teeth strong; muscular impressions large. Length two inches." Conrad, 1833.

Occurrence.-St. Mary's Formation. St. Mary's River. Choptank Formation. Governor Run, Jones Wharf, Cordova, Sand Hill. CaLvert Formation. Chesapeake Beach. Reed's.

Collections.-Philadelphia Academy of Natural Sciences, Maryland Geological Survey, Johns Hopkins University.

$$
\begin{gathered}
\text { Spisula (Hemimactra) subparilis (Conrad). } \\
\text { Plate LXX, Figs. 6a, 6b. }
\end{gathered}
$$

Mactra subparilis Conrad, 1841, Amer. Jour. Sci., vol. xli, p. 346, pl. ii, fig. 12.

Mactra subparilis Conrad, 1845, Fossils of the Medial Tertiary, p. 69, pl. xxxis, fig. 4 .

Standella subparilis Conrad, 1863, Proc. Acad. Nat. Sei. Phila., vol. xir, p. 573.

Standella subparilis Meek, 1864, Miocene Check List, Smith. Misc. Coll. (1S3), p. 11.

Spisula (.Mutromeris) subpuritis Dall, 1898, Trans. Wagner Free Inst. Sci., vol. ili, pt. ir, p. 900 . 
Description.- "Triangular, clongated, moderately thick, convex-depressed; posterior side cuneiform; apex hardly oblique, subcentral; fosset wide; lateral teeth transversely striated." Conrad, 1841.

Only young specimens have been obtained in Maryland.

Occurrence.-Choptank Formation. Governor Run, 2 miles sonth of Governor Run, Flag Pond, Jones Wharf, Pawpaw Point. Calvert Formation. 3 miles south of Chesapeake Beach, Plum Point.

Collections.-U. S. National Museum, Maryland Geological Survey.

Spisula (Heminactra ?) chesapeakensis n. sp.

Plate LXXI, Fig. 1.

Description.-Shell large, thim, not inflated, subtrigonal, anterior and posterior sides nearly equal, surface smooth; anterior end well rounded, posterior end rather more sharply rounded; anterior hinge line straight, posterior hinge line gently convex, just posterior to the beak, otherwise straight; angle between anterior and posterior hinge lines about $105^{\circ}$; basal margin strongly curved anteriorly and posteriorly; hinge area hroad; lateral teeth prominent; chondrophore long, narrow, triangular, oblique.

A single right valve of this magnificent species has been obtained. It is in the form of a cast, with a portion of the shell substance preserred and the outline and main hinge features easily distinguishable. It is much larger than any of the other Miocene Spisulas; S. subponderosa is nearest it in size, but is smaller, much heavier, more elevated, and has a curved posterior hinge line and a broader, shorter chondrophore.

Length, $130 \mathrm{~mm}$; height, $95 \mathrm{~mm}$.

Occurrence.-Calnert Foration. 3 miles north of F'lum Point.

Collection.-Maryland Genlogical Survey.

Genus LABIOSA (Schmidt) Moller.

Subgenus RAËTA Gray.

LABIOSA (RÄ̈TA) SP.

Description.-At Reed's marl pit have been found numerous fragments of a Labiosa showing an undular concentric sculpturing much stronger than $R$. alta, in fact as strong as $L$. canaliculata. As this latter species is known only in the Pleistocene and Recent it is very probable that 
the fragments found at Reed's belong to a new species. It is best not to attempt to name or describe a new species from the broken material at hand, but the presence of a species in the Miocene at this locality should be noted in the hope that some later investigator may be fortunate enough to secure material suitable for specific characterization.

Occurrence.-Calvert Formation. Reel's.

Collection.-Maryland Geological Surrey.

\section{Superfamily SOLENACEA. \\ Family SOLENIDÆ. \\ Genus ENSIS Schumacher. \\ ENsis DIRECTUS (Conrad). \\ Plate LXXI, Figs. 2, 3.}

Solen ensis Conrad, 1\$4:, Proc. Nat. Inst., Bull. ii, p. 191 ; not of Liuné.

Solen directus Conrad, 1843, Proc. Acad. Nat. Sci. Phila., vol, i, p. 325.

Solen mugnodtntutus H. C. Lea, 1845, Trans. Amer. Philos. Soc., vol. ix, p. 236, pl. xxxir, tig. S.

Solen ensis T'uomey and Holmes, 1856, Pleiocene Fossils of South Carolina, p. 101, pl. xxiv, tig. 3.

Solen americanus Gould (Binney's), 1870, Invert. Mass., p. 42.

Ensatella americana Verrill, 18т2, Amer. Jour. Sci., ser. iii, vol. ii, pp. 212, 254.

Ensatella umericana Verrill, 1874, Rept. Invert. An. Vin. Sound, 1. 674, pl. xxxii, tig. 245 .

Ensis americana Dall, 1859, Bull. xxxvii, U. S. Nat. Mus., p. 72, pl. liii, tig. 4; pl. Iv, figs. 4,5 .

Ensis directus Dall, 1900, Trans. Waguer Free Inst. Sci., vol. iii, pt. v, p. 954.

Description.- " Linear, straight, except towards the summit, where it is slightly recurved, gradually widening from the hinge downwards; basal margin rounded slightly towards the posterior extremity; anterior margin obliquely truncated, not reflected; cardinal teeth, one in the right valve, compressed, in the opposite ralve two, the superior one rery small and near the extremity, the other somewhat distant, elevated, robust, slightly recurved. Length, four inches." Conrad, $18 \pm 3$.

It is distinguished from $E$. ensiformis by being larger and by its more squarely truncated posterior end. It is almost impossible to secure more than broken pieces in the Maryland deposits.

Occurrence.-St. Mary's Formation. St. Mary's River.

Collection.-Maryland Geological Survey. 
Exsis ensiforinis Conrad.

Plate LXXI, Figs. 4, 5, 6.

Solen ensiformis Conrad, 1845, Proc. Acad. Nat. Sci. Phila., vol. i, p. 326.

Solen ensiformis Conrad, 1845, Fossils of the Medial Tertiary, p. 76, pl. xliii, tig. 8 .

Ensis ensifonmis Courad, 1863, Proc. Acad. Nat. Sci. Plila., vol. xir, p. 5r1.

Ensis ensiformis Meek, 1864, Miocene Check List, Smith. Misc. Coll. (1\$3), 1. 12.

Ensis cusiformis Dall, 1900, Trans. Wagner Free 1nst. Sci., vol. iii, pt. v, p. 955.

Description._" Linear, slightly curved, gradually narrowed from the middle to the posterior extremity, which is subcuneiform; anterior margin obliquely subtruncated." Conrad, 1845.

Shell thin, fragile; teeth two in left valve, separated by a very narrow deep cleft, in right valve one; anterior extremity flaring; posterior extremity tapered, rounded and gaping.

Although quite abundant at Cove Point, it is almost impossible to obtain it except in fragments.

Occurrence.-St. Mary's Fonmation. Cove Point, St. Mary's River. Choptank Formation. Jones Wharf, Sand Hill, Greensboro. Calvert Formation. Fairhaven, Plum Point, Reed's.

Collections.-Maryland Geological Survey, Johns Hopkins Tniversity.

\author{
Superfamily TELLINACEA. \\ Family PSAMMOBIIDÆ. \\ Genus PSAMMOBIA Lamarck. \\ Subgenus PSAMMOBIA s. s. Dall. \\ Psamimobia GUBERnatoria n. sp. \\ Plate LXXI, Figs. \%a, \%b.
}

Description.-Shell long-ovate, thin, fragile, depressed or flat, inequilateral; anterior end being broader and longer than the posterior one; beak very low; anterior side slightly curved and for some distance from the beak nearly parallel with the base; anterior end regularly rounded and broad; posterior side with broad projecting hinge plate; posterior side declining; posterior end rounded and more nearly on line of base than anterior end; base only slightly curved; lateral teeth none, cardinals in right ralve two; posterior addnctor scar oval, anterior one larger and 
somewhat elongated, both distinct; pallial sinus profound, rounded, faint; exterior semi-polished with faint concentric growth lines discernible; dorsal and posterior slopes meeting in an abrupt curve running from beak to base and becoming less marked near the base.

Length, $35 \mathrm{~mm}$; height, $17 \mathrm{~mm}$; diameter, $3.5 \mathrm{~mm}$.

Occurrence.-Choptank Formation. Governor Run, Jones Wharf. Caljert Formation. Plum Point.

Collection.-Maryland Geological Survey.

Genus ASAPHIS Modeer.

Asaphis Centenaria (Conrad).

Plate LXXI, Figs. S, 9.

Peticole centenurie Conrad, 1833, Amer. Jour. Sci., vol, xxiii, p. $3+1$.

Petricole centenuria Courad, 1838, Fossils of the Medial Tertiary, p. 17, pl. x, fig. 1.

Psumacolte ieyiu II. C. Lea, 1845, Trans. Amer. Philos. Soc, vol. ix, p. 284, pl. xxxiv, tig. 17.

Psammocolu pliocenu Tuomey and Holmes, 1856, Pleiocene Fossils of South Carolina, p. 91, pl. xxii, fig. s.

Pliorytis centenariu Courad, 1863, Proc. Acad. Nat. Sci. Phila., vol. xiv, 1'. 5\%6.

Astphis centenurir Dall, 1900, Trans. Wagner Free Inst. Sci., vol. iii, pt. v, p. 981.

Description._ " Shell oblong oval, with numerous prominent radiating striæ, and concentric wrinkles; lunule small, cordate, profoundly impressed; hinge with two teeth in one valve and three in the opposite, the middle one bifid. Length, two inches." Conrad, 1833.

Shell somewhat variable in outline and in proportion of length to altitude; irregular surface undulations quite marked or almost absent; the fine radial ridges usually somewhat undulating and often more distant on the anterior slope; left valve with but two teeth, the anterior one bifid and bounded anteriorly by a deep socket; a well-marked groove backward from the beak across the posterior hinge area; pallial sinus profound and rounded anteriorly; shell slightly gaping posteriorly.

Length, $53 \mathrm{~mm}$.; height, $35 \mathrm{~mm}$.; diameter, $10 \mathrm{~mm}$.

Occurrence.-ChoptanK Formation. Governor Run, 2 miles south of Governor Run, Flag Pond, St. Leonard Creek, Jones Wharf, Pawpaw Point, Dover Bridge, Peach Blossom Creek, Greensboro. Calvert Formation. Fairhaven, Plum Point, Lyon's Creek, Magruder Ferry.

Collections.-Maryland Geological Survey, Johns Hopkins University. 


\section{Family SEMELIDÆ.}

Genus SEMELE Schumacher.

SEMEle Carinata (Conrad).

Plate LXXII, Figs. 1, 2, 3.

Amphidesma curinata Conrad, 1830, Jour. Acad. Nat. Sci. Phila., rol. vi, 1st ser., p. 2:9, pl. ix, fig. 25.

Amplidesma carinatu Conrad, 1838, Fossils of the Medial Tertiary, p. 37, pl, xix [1st ed.], fig. 7 ; [2nd ed.], fig. 11, 1840.

Sinodesmin carinata d'Orbigny, 1852, Prod. Pal., rol. ii, p. 101, No. 1590.

Sinodesmia carinuta Tuomey and Holmes, 1856, Pleiocene Fossils of South Carolina, p. 93 , pl. xxiii, tig. 2.

Abra carinatu Conrad, 1863, Proc. Acad. Nat. Sci. Phila., vol. xir, p. 574.

Abro curinata Meek, 1864, Miocene Check List, Smith. Misc. Coll. (183), 1) 11.

Abre Holmesii Conrad, 1875, Rept. N. Car. Geol. Survey, vol. i, app. A, p. 19, pl. iii, tig. $s$.

Semele carinuta Dall, 1900, Trans. Wagner Free Inst. Sci., vol, iii, pt. v, p. 988, pl. xxxi, tigs. $23,26$.

Description.- "Shell transversely orate, with concentric, rather distant, elevated, acute strix; intervals transversely striated; anterior side with a slight fold; heaks rather prominent, with the aper acute; lateral teeth none." Conrad, 1830.

Fine concentric striæ between the distant. elevated ones; posterior side with a slight fold; posterior basal margin obliquely truncated; lateral laminæ in left valve small, in right valve lateral lamina and sockets distinct : muscle impressions subequal; pallial simus profound.

Length, $22 \mathrm{~mm}$. ; height, $16 \mathrm{~mm}$. ; diameter, $4 \mathrm{~mm}$.

Occurrence.-St. Mary's Formation. Core Point, St. Mary's River. Choptank Formation. Cordova. Calvert Formation. Chesapeake Beach, 3 miles sonth of Chesapeake Beach, Plum Point. Truman's Wharf.

Collections.-Waryland Geolngical Survey, Johns Hopkins University, U. S. National Museum.

Semele carinata var. compacta Tall.

Plate LXXII, Figs. 4, วa, 5̆b.

Semele curinata var. compacta Dall, 1900, Trans. Wagner Free Inst. Sci., vol. iii, pt. v, pp. 988, 989, pl. xxxvi, figs. 23,26 .

Jescription.-This variety, to which the figures given by Dr. Dall for S. curinuta (cited above) more directly belong. is discriminated by him 
from the $S$. carinata by having " a somewhat more elongated form and more uniform and close-set sculpture, especially over the posterior dorsal area. The size of those collected is also smaller than that of the fullgrown Miocene specimens."

Occurrence-St. Marr's Fonmation. St. Mary's River. Choptaxk Foralition. Jones Wharf.

Collection.-Maryland Geological Surrey.

\section{Seliele subovata (Say).}

Plate LAxII, Figs. 6, \%. S.

Amphidesma subocuta Say, 1824, Jour. Acad. Nat. Sci. Phila., vol. iv, 1st ser., 1. 152, pl. $x$, fig. 10.

Amphidesmu subovutu Conrad, 1840, Fossils of the Medial Tertiary, p. 36. Syndosmya subobliqua Conrad, 1854, Proc. Acad. Nat. Sci. Phila., vol. vii, p. 29.

Abra ovulis Conrad, 1862, Proc. Acad. Nat. Sci. Phila., vol. xir, p. 288.

Abra suboutu Conrad, 1863, Proc. Acad. Nat. Sci. Phila., vol. xiv, p. 574.

Abra subouta Meek, 1864, Miocene Check List, Smith. Misc. Coll. (183), p. 11.

Semele subovate Dall, 1900, Trans. Wagner Free Inst. Sci., rol. iii, pt. v, p. 990.

Description.- "Shell transversely ovate-oval, with somewhat prominent and regular concentric strix.

"Shell compressed: beaks rather before the middle, but little prominent; anterior submargin with an obsolete, obtuse undulation; lunule lanceolate; cardinal and lateral teeth prominent." Say, $182 t$.

This species may be distinguished from $S$. carinata by having all of its concentric striæ of about equal prominence and by having a somewhat more elongated and thinner shell. Lateral teeth in left valve not prominent, in the right prominent.

Length, $20.5 \mathrm{~mm}$.; height, $14 \mathrm{~mm}$.; diameter, $3 \mathrm{~mm}$.

Occurrence.-St. Mary's Formatiox. Cove Point, St. Mary's River. Chortaxk Fordation. Govermor Run, 2 miles south of Governor Run, Jones Wharf, Peach Blossom Creek, Dover Bridge, Greensboro, Cordora. Calvert Formatiox. Fairhaven, 3 miles west of Centerville, Church Hill.

Collections.-Maryland Geological Surrey, Johns Hopkins University. 
Genus ABRA Leach.

Abra longicallus (Scacchi).

Plate LXXII, Figs. 9a, 9b.

Tellinu longicallus Scacchi, 1836, Notizie intorno alle Conchiglie ed a zoofiti fossili, p. 16, pl. i, tig. 7 .

Description.-Shell ovate, thin, convex or vaulted; beak not prominent; anterior and posterior sides straight, meeting at an angle; anterior end broad and regularly rounded; posterior end very acutely rounded, much above the line of the base and gaping; base regularly curved; posterior adductor scar rounded; anterior one elongated; pallial sinus long and irregularly curved; in right valve the lateral lamina on either side rather short and bordered by a moderately deep groove; cardinals two, minute; chondrophore elongated, narrow, oblique, closely grown to the posterior hinge line; exterior surface smooth.

Length, $11.5 \mathrm{~mm}$; height, $7.1 \mathrm{~mm}$. ; diameter, $2 \mathrm{~mm}$.

Occurrence.-Сhoptank Formation. Jones Wharf.

Collection.-Cornell University.

\section{ABRA MARYLANDICA n. sp.}

Plate LXXIT, Fig. 10.

Description.-Shell small, compact, stout, vaulted; anterior end produced and rounded; posterior end shorter, more pointed; and nearer the line of the base; anterior and posterior dorsal margins nearly straight, anterior one nearly parallel to the basal margin, posterior one much more declining; beak not prominent, but angular; exterior polished and smooth except for a few feeble concentric growth lines near the margin, muscle impressions and pallial line faint, interior polished; in left valve a narrow fosset directed posteriorly and close set against the posterior margin; anterior to it is a small triangular cardinal tooth, posterior to it the margin is slightly raised as if into a faint lamina and slightly flaring or reflexed near the beak.

Length, $7 \mathrm{~mm}$.; height, $4.5 \mathrm{~mm}$.; diameter, $1.6 \mathrm{~mm}$.

Occurrence.-Calvert Formation. Phum Point.

Collection.-Maryland Geolngical Survey. 


\section{Genus CUMINGIA Sowerby.}

\section{Cumingta medialis Conrad.}

\section{Plate LXXII, Figs. 11, 12.}

Cumingia tellinviles Conrad, 1838, Fossils of the Medial Tertiary, p. 28, pl. xv, fig. 4 .

Not Cumingin telinuides Conrad, 1831.

Anutine tellinoides 11. C. Lea, 1845, Traus. Amer. Philos. Soc., vol. ix, p. 233\%, pl. xxxiv, tig. 1:.

Lreignon tellinoides d'Orbigny, 185:, Prod. Pal. Strat., vol, iii, p. 101, No. 1891.

Lavignon tellinoides Tuomey and Holmes, 1856, Plejocene Fossils of south Carolina, p. 9:, pl. xxiii, fìg. 1.

Cumingia tellinoides Conrad, 1863, Proc. Acad. Nat. Sei. Phila, vol. xiv, 1. 5it.

Cumingia tellinoides Meek, 1864, Miocene Check List, Smitl. Misc. Coll. (183), p. 11.

Cumingir medialis Conrad, 1866, Amer. Jour. Conch., vol, ii, p. 106.

Cumingir mediulis Dall, 1900, Trans. Wagner Free Inst. Sci., vol. iii, pt. v, p. 999.

Description.-"Shell ovate-trigonal, thin, with numerous prominent concentric wrinkled striæ; anterior side ventricose; the posterior side contracted, subcuneiform; the base near the extremity slightly emarginate; cardinal fosset large ; lateral teeth very prominent." Conrad, 1838.

The anterior side is inflated, the posterior side depressed, this depression extending to the base and producing a slight emargination near the posterior extremity; within, chondrophore prominent, projecting, spoonshaped. Two left valves in some material belonging to the Johns Hopkins University are labeled from Jones Wharf, but their state of preservation and coloration makes it seem more probable that they are from Virginia.

Length, $25 \mathrm{~mm}$.; height, $18 \mathrm{~mm}$.; diameter, $5.5 \mathrm{~mm}$.

Occurrence.-Choptank Formation (?). Jones Wharf (?).

Collection.-Johns Hopkins University.

\section{Family TELLINIDÆ.}

Genus TELLINA (Linné) Lamarck.

Section MERISCA Dall.

TELEINA AEqUISTRIATA Say.

Plate LXXII, Fig. 13.

Tellinu aquistricter Say, 1824, Jour. Acad. Nat. Sci. Phila,, vol, iv, 1st ser., p. 145, pl. x, fig. \%. Reprint, Bull. Amer. Pal., rol. i, No. 5, 1. 321, pl. sxix, fig. 7.

Telline (Aeriser) requistriutu Dall, 1900, Trans. Wagner Free Inst. Sci., vol. iii, pt. v, p. 1020 . 
Description._." Shell transversely ovate-orbicular, with an elevated line or fold on the anterior margin : surface with fine, somewhat elevated, concentric, nearly equal, numerous strix, forming grooves between them: apex nearly central, acute: cardinal teeth deeply grooved: lateral teeth two; edge within, simple.

"Length seven-tenths, lreadth nineteen-twentieths of an inch.

"In general outline, this species has a resemblance to T. ostracea, Lam. In one specimen the apex is central, and $j n$ another it is placed before the middle." Say, 1824.

This is one of Finchis collection, purporting to be from Maryland, but some of which were undoubtedly from Virginia. I am inclined to believe the reference of this species to Maryland probably incorrect, but give it on Finch's uncertain authority. A specimen in the collection of Johns Hopkins University labelled "Jones Whart" is stained like the Yorktown. Va., material, and I think is most likely from there.

Occurrence.-Choptaxk Formatios (?). Jones ITharf (?).

Collection.-Johns Hopkins University.

Subgenus ANGULUS Megerle.

Tellina (Angulus) decioivis Comrad.

Plate LXXII, Fig. 14.

Tellina declivis Conrad, 1834, Jour. Acad. Nat. Sci. Phila., vol. vii, 1 st ser., p. 131. Tellinu declivis Courad, 1840, Fossils of the Medial Tertiary, p. 35, pl. xix, fig. 1.

Tellinu declivis Conrad, 1863, Proc. Acad. Nat. Sci. Phila., vol. xiv, p. 573.

Tellinu [Angulus] declivis Meek, 1864, Miocene Check List, Smith. Misc. Coll. (1S3), p. 10.

Tellinu (Angulus) declivis Dall, 1900, Trans. Wagner Free Inst. Sci., vol. iii, pt. v, p. $10: 29$

Description.-" Shell somewhat elliptical, with the anterior" side short, and the margin obliquely truncated; posterior end regularly rounded; beaks hardly prominent; lateral teeth distinct.

"It resembles in ontline the Amphidesma subreflexa, nobis; and might, viewing the exterior only, be mistaken for that shell." Conrad, 1834.

'The posterior dorsal margin of this species is more abruptly or angularly declining than in T. producta. The anterior dorsal margin is also less nearly parallel to the base, and hence the beak is more prominently angular. 
Length, $13.4 \mathrm{~mm}$; height, $\mathrm{S} \mathrm{mm}$; diameter, $1.95 \mathrm{~mm}$.

Occurrence.-Choptank Formatron. Jones Wharf. Calvert Formation. Plum Point.

Collections.-U. S. National IIuseum. Maryland Geological Survey.

Tellina (Axgulus) producta Comrad.

Plate LXXII, Figs. 15, 16.

Tellina productu Conrad, 1840, Fossils of the Medial Tertiary, p. 36, pl. xix, fig. 5.

Tellina (Pevoncederma) producta Conrad, 1863, Proc. Acad. Nat. Sci. Phila., vol. xiv, p. 573.

Tellina (Peroneodernert) producta Meek, 1864, Smith. Yisc. Coll. (183), p. 10.

Telline (Angulus) producte Dall, 1900, Trans. Wagner Free Inst. Sci., vol. iii, pt. v, p. 1029 .

Iacome (Psammacome? producta Dall, 1900, Trans. Wagner Free Inst. Sci., vol. iii, pt. $\nabla$, p. 1054 .

Description._"Shell narrow-elliptical, compressed; posterior side pointed, extremity obtuse; fold submarginal, obscure; basal margin straight opposite the beak; lateral teeth none." Conrad, $18 \pm 0$.

Anterior dorsal margin is more nearly parallel to the base than in A. declivis and posterior portion is more produced, posterior dorsal margin being less declining.

Length, $11 \mathrm{~mm}$; height, $6 . \pm \mathrm{mm}$; diameter, $1.4 \mathrm{~mm}$.

Occurrence.-St. Marr's Formation. Cove Point, St. Mary's River (Meek: fide Dall). Calrert Formation. Plum Point. Blake's (fide Dall).

Collections.-U. S. National Museum, Maryland Geological Survey.

Tellina (Axgulus) dupliniaxa Dall.

Plate LXXIII, Fig. 1.

Tellina (Angulus) dupliniana Dall, 1900, Trans. Wagner Free Inst. Sci., vol. iii, pt. v, p. 1032, pl. xlvi, fig. 17.

Description._- Shell small, solid, rather convex, inequilateral, dorsal margins rectilinear, diverging at an angle of about one hundred and eight degrees, anterior end longer, rounded evenly into the base, which is nearly parallel with the anterior dorsal margin; posterior end much shorter, pointed, the terminal angle slightly decumbent and the basal margin in front of it slightly incurved; beaks inconspicnous, hinge normal, the right 
adjacent lateral short and the anterior hinge-margin in front of it grooved for the edge of the opposite valve; middle of the disk smooth, the beaks, posterior dorsal area, and the portions of the disk near the basal margin more or less concentrically striated; interior with the pallial sinus rising to a small angle under the umbo, then descending in a somewhat wavy line to a point on the pallial line considerably short of the anterior adductor scar; in the left valve the sinus is not angulated above and extends somewhat nearer the adductor; the interior is marked with some faint radiations near the adductors, but no thickened ray appears.

"There is some little difference in the proportional height in different individuals, in the amount of inflation, and in the arcuation of the posterior dorsal margin; the posterior fold, or ridge bounding the posterior dorsal area, is not strongly marked. Compared with T. tenella Terrill, this species is a heavier and higher shell, with the posterior end more pointed and decurved. The dorsal margin of the right valve is not grooved in T. tenella, and the adjacent lateral is longer than in $T$. dupliniana of the same size." Dall, 1900.

Length, $12.5 \mathrm{~mm}$. ; height, $8 \mathrm{~mm}$.; diameter, $4 \mathrm{~mm}$.

Occurrence.-Calvert Forination. Plum Point (fide Dall).

Collection.-U. S. National Museum.

\section{Tellina (Axgulus) unbra Dall.}

Plate LXXIII, Fig. 2.

Tellinu (Angules) nmbru Dall, 1900, Trans. Wagner Free Inst. Sci., vol. iii, pt. v, p. 1033, pI. xlvi, fig. 13 .

Description.- " Shell small, solid, markedly flexuous, moderately convex, inequilateral, nearly equivalve; anterior end longer, rounded; posterior end shorter, attenuated, bluntly pointed; beaks inconspicuous; whole surface covered with (lose-set, regular, even, concentric threads; hinge normal, right anterior lateral short and stout, posterior lateral small but prominent; pallial sinus long, slightly convex above, reaching to the anterior ray (which is obviously thickened), nearly similar in both valves, and wholly confluent below.

"This species is nearest to T. sybaritica. Dall, but is a larger and less slender shell, with a less angular posterior end. It is doubtless the precursor of that species." Dall. 1900. 
Length, $12.5 \mathrm{~mm}$.; height, $6.5 \mathrm{~mm}$; diameter, $3.5 \mathrm{~mm}$. (Dall). Occurrence.-St. Marr's Fonmation. St. Mary's River (fide Dall). Calvert Formation. Plum Point.

Collections.-U. S. National Museum, Maryland Geological Surrey.

Genus METIS H. and A. Adams.

Mietis biplicata Conrad.

Plate LXXIII, Figs. 5, 6.

Telline biplicata Conrad, 1834, Jour. Acad. Nat. Sci. Phila., vol, vii, 1st ser., p. 152. Tellina biplicate Conrad, 1840, Fossils of the Medial Tertiary, p. 36, pl. xix, fig. 4; not of Tuomey and Holmes or Emmons.

Metis biplicute Conrad, 1863, Proc. Acad. Nat. Sci. Phila., vol. xiv, p. 573.

Metis biplicata Meek, 1864, Miocene Check List, Smith. Misc. Coll. (183), p. 11.

Metis biplicuta Dall, 1900, Trans. Wagner Free Inst. Sci., vol. iii, pt. v, p. 1042.

Description._" Shell suboval, inequivalve, slightly ventricose, with obscure radiating lines, and prominent filiform striæ, much elevated over the folds of the posterior side; folds two, one on each valve angular; cardinal teeth two in the right valve, much compressed, posterior one profoundly bifid; one similar bifid tooth in the opposite valve; hinge margin profoundly sulcated posteriorly; lateral teeth none." Conrad, $183 \pm$.

Length, $60 \mathrm{~mm}$.; height, $51 \mathrm{~mm}$.; diameter, $12 \mathrm{~mm}$.

Occurrence.-St. Mary's Formation. Cove Point. Choptank Formation. Governor Run, 2 miles south of Governor Run, Flag Pond, Cuckold Creek, St. Leonard Creek, Jones Wharf, Sand Hill, Dover Bridge, Cordova. Calvert Formation. Plum Point, White's Landing, Wye Mills.

Collections.-Maryland Geological Survey, Johns Hopkins University.

Genus MACOMA Leach.

Macoma lenis (Conrad).

Plate LXXIII, Figs. 3, 4.

Tellina lenis Conrad, 1843, Proc. Acad. Nat. Sci. Phila., rol. i, p. 506.

Tellina lenis Conrad, 1845, Fossils of the Medial Tertiary, 1'. 72, pl. xli, tig. 9.

Tellina (Peroncederma) lenis Conrad, 1863, Proc. Acad. Nat. Sci. Phila., rol. xiv, p. 578 .

Tellina (Peroncooderma) lens Meek, 1\$64, Miocene Check List, Smith. Misc. Coll. (183), p. 10 (typ. er.).

Iracoma lenis Dall, 1900, Trans. Wagner Free Iust. Sci., vol. iii, pt. v, p. 1047. 
Description._" Subelliptical: beaks medial; anterior margin obliquely truncated, the extremity acutely rounded; dorsal margins equally oblique; posterior basal margin obliquely subtruncated; basal margin nearly straight in the middle and towards the anterior extremity where it is arched; the extremity considerably above the line of the base; posterior side with an oblique narrow fold." Conrad, $18+3$.

Shell very thin; surface crossed by fine concentric lines of growth; within, a well-defined ridge extending from the beak obliquely backward to the lower part of the posterior margin and there becoming obsolete.

Length, $50 \mathrm{~mm}$. ; height, $32 \mathrm{~mm}$. ; diameter, $7.5 \mathrm{~mm}$.

Occurrence.-Choptank Formation. Jones Wharf (rare). CaLvert Formation. Three miles south of Chesapeake Beach, Lyon's Creek (?).

Collection.-Maryland Geological Surrey.

Hacoma marilandica n. sp.

Plate LXXIII, Fig. $\%$

Description.--Shell rery thin and fragile; basal and anterior dorsal margins nearly parallel; anterior side produced and anterior end rounded; anterior basal margin regularly arched; posterior dorsal margin declining and meeting basal margin much ahove the line of the base: anterior portion of shell convex and eapacious, especially under the beak and anterior dorsal margin; posterior portion of shell contracted and somewhat pointed and posterior end gaping; exterior smooth except for faint growth lines; cardinal teeth two; beak not prominent.

Length, $15 \mathrm{~mm}$; ; height, $7.9 \mathrm{~mm}$.; diameter, $1.8 \mathrm{~mm}$.

Occurrence.-St. Mary's Formation. St. Mary's River.

Collection.-Naryland Geological Survey.

\section{Superfamily VENERACEA. \\ Family PETRICOLIDÆ. \\ Genus PETRICOLA Lamarck. \\ Section RUPELLARIA Fleuriau. \\ Petricola harrisit Dall. \\ Plate LXXIII, Figs. 8, 9.}

Peticolu (Rupelluriu) Harrisii Dall, 1898, Trans. Wagner Frec Inst. Sci., vol. iii, pt. v, p. 1060, pl. xliii, tig. 1. 
Description._- "Shell solid, ovate, distorted more or less by the irregularities of its situs; posterior end blunt, longer; anterior end shorter, rounded; sculpture of fine, nearly uniform radial rounded threads with wider interspaces, crossed by fine, rounded, slightly elevated incremental lines; beak moderately elevated, hinge short, with, in the left valve, one strong, apically grooved cardinal between two simple narrow diverging teeth; ligamentary nymph short, strong, deeply grooved; basal margin feebly crenulated by the external sculpture; pallial sinus wide, shallow." Dall, 1900.

Length, $20 \mathrm{~mm}$.; width, $23 \mathrm{~mm}$.; diameter, $7 \mathrm{~mm}$.

Occurrence.-ChOPtank Formation. Governor Run, 2 miles south of Governor Run, Jones Wharf, Dover Bridge.

Collection.-Maryland Geological Survey.

\section{Section PETRICOLARIA Stoliczka. \\ Petricola calvertensis Dall. \\ Plate LXXIII, Figs. 10, 11, 12.}

Petricola (Petricolaria) calvertensis Dall, 1900, Trans. Wagner Free Inst. Sci., vol. iii, pt. v, p. 1060 , pl. xliv, fig. 14.

Description.- "Shell elongate-oval, with the beaks near the anterior" third, solid, closely regularly sculptured with fine radiating threads, the interspaces wider, the threads a little stronger towards the ends of the shell, concentric sculpture only of fine somewhat irregular incremental lines; beaks rather elevated: shell moderately inflated, more or less irregular from nestling among rocks, sculpture near the beaks quite faint; hinge short, a spur from the lunular region extending over and past the cardinal teeth behind the beaks; hinge normal; margins entire; pallia] sinus deep and rounded." Dall, 1900.

Height, $9 \mathrm{~mm}$.; width, $17 \mathrm{~mm}$.; diameter, $3.5 \mathrm{~mm}$.

Occurrence.-St. Mary's Formation. Cove Point. Choptank Foruation. Jones Wharf, Calvert Cliffs (Burns and Harris).

Collections.-Maryland Geological Survey, U. S. Nätional Museum. 


\title{
Family VENERIDÆ.
}

\author{
Subfamily VENERINA. \\ Genus VENUS (Linné) Lamarck. \\ Venus duCATELLI Conrad. \\ Plate LXXV, Figs. ‘, 8.
}

Teuns Ducretli Conrad, 1sas, Fossils of the Medial Tertiary, p. s, pl. iv, fig. 2. Tenus Ducatelli; Conrad, 1863 , Proc. Acad. Nat. Sce. Phila., vol, xiv, p. 5it.

Venus Incatellii Meek, 1S6t, Miocene Check List, Smitl. Misc. Coll. (18:3), p. 9.

Tems Ducuteli Whitfield, 1894, Mon. xxiv, U. S. Feol. Survey, p. $6 \%$ (in part), pl. xi, figs. $1-3$.

I'enus Inecateli Dall, 1903, Trans. Wagner Free Inst. Sci., vol. iii, pt. vi, p. 1309.

Description. - "Shell suborbicular, convex, thick; disks with numerous approximate, recurved ribs, laminar and much elevated towards the posterior margin; extremity obtuse; beaks distant from the anterior margin; umbo not inflated; lunule defined by an impressed line, not very profound; posterior margin rectilinear; two of the cardinal teeth in the left valve remote, thick, bifid; anterior tooth much compressed.

"This shell is related to T. Mortoni, but is much smaller, less ventricose, and has more prominent ribs. It is obtained in fragments only, but those are abundant. It is named in compliment to the state Geologist of Maryland, Professor Ducatel." Conrad, 1838.

Length, $70 \mathrm{~mm}$. ; height, $56 \mathrm{~mm}$; diameter, $20 \mathrm{~mm}$.

Occurrence.-Calverit Fornatiox. Church Hill.

Collections.-Maryland Geological Survey, Johns Hopkins University.

Venus RILeyi Conrad.

Plate LXXVI, Figs. 4, 5.

T'enus Rileyi Conrad, 1s3s, Fossils of the Medial Tertiary, p. 9, pl. vi, fig. 1.

I'enus Rileyi Tuomey and Ifolmes, 1856, Pleiocene Fossils of South Carolina, p. 7S, pl. xxi, fig. s.

Tenus Rileyi Emmons, 1858, Rept. N. C. Geol. Survey, p. 292.

Meremurir Rileyi Conrad, 1863, Proc. Acad. Nat. Sci. Phila., vol, xiv, p. 574.

Mercenarin Rileyi Meek, 1864, Miocene Check List, Smith. Misc. Coll. (183), p. 9.

Tenus triducnoides var. Rileyi Dall, 1903, Trans. Waguer Free Inst. Sci., vol. iii, pt. vi, pp. $1310,1811$.

Description._" Shell obliquely ovate, slightly ventricose, thick, very inequilateral; disks with small crowded reflected concentric ribs; anterior 
side narrowed; umbo very oblique, prominent; posterior margin arcuate; inner margin deeply crenulated.

"This shell has probably been confounded with $V$. tridacnoides, but it is much thinner, not undulate on the disk, and the cardinal teeth are much less robust. Its narrowed and compressed anterior side will distinguish it from the other fossil species, and its ribs from the recent $V$. mercenaria. Young shells are compressed or plano-convex. The disks are generally worn, showing the radiating striæ common to all these large fossil species when the surface becomes decomposed. It is named in compliment to my scientific friend, Dr. William Riley of Baltimore." Conrad, 1838.

This species as found at Plum Point is not notably thick. The hinge area is narrow, and the teeth rather small. The umbo can scarcely be consiclered prominent. The great proportionate length of the shell distinguishes this species readily from the others of the Miocene. None of the Plum Point specimens slow the great thickening or undulations on the disk so characteristic of the tridacnoides as found at numerous Virginia localities. For this reason, and because the Virginia beds in which thickened shells are found are much higher stratigraphically in the Miocene than the Plum Point beds the writer prefers to retain the name rileyi for a distinct species.

Length, $115 \mathrm{~mm}$; height, $80 \mathrm{~mm}$; diameter, $22 \mathrm{~mm}$.

Occurrence.-Calvert Formation. Plum Point.

Collections.-Maryland Geological Survey, Johns Hopkins University.

VENUS Mercenaria Iimné.

Plate LXXVIII, Figs. 1, 2.

Venus mercenuria Linué, 1758, Syst. Nat., Edit. x, p. 686.

Venus mercenrria Tuomey and Holmes, 1856, Pleiocene Fossils of South Carolina, p. s1, pl. xxi, tig. 6.

Ienus mercenuia Emmons, 1858, Rept. N. Car. Geol. Survey, p. 292.

Merceuria violacea Holmes, 1558, Post-Pleiocene Fossils of South Carolina, p. 33, pl. vi, fig. 11.

Mercenaria mercenuria Conrad, 1863 , Proc. Acad. Nat. Sci. Phila., vol. xiv, p. 5 it. Venus mercenaria Gould (Binuey's), 1870, Invert. Ilass., 1. 133, fig. 445.

Mercenuria conrellate Whitfield, 1894, Mon. xxiv, U. S. Feol. Survey, p. 68, 1. xii, figs. 2-3.

Tenus merenarin Dall, 190:3, Trans. Wagner Free Inst. Sci., vol. iij, pt. vi, 1) 1311. 
Description.-Shell solid, ovate cordate; beak curved well forward, not very prominent; outer surface with close-set, concentric lamellæ; lunule marked, cordate; hinge area rather short, broad; cardinal teeth strong, two in right valve strongly bifid; posterior margin arched; a broad, shallow impressed area or groove from beak to posterior margin just above its point of meeting with the base; muscle impressions large and distinct; pallial sinus acutely angular; inner margin crenulated.

Length, $96 \mathrm{~mm}$. ; height, $79 \mathrm{~mm}$.

Occurrence.-C.hoptank Foralation. Governor Run. Calvert ForMation. Plum Point.

Collections.-Maryland Geological Survey, Johns Hopkins University.

$$
\begin{aligned}
& \text { Venus PLena (Conrad). } \\
& \text { Plate LXXIX, Figs. 1, } 2 .
\end{aligned}
$$

Mercentrie plenu Conrad, 1569, Amer. Jour. Conch., vol. v, p. 100.

Verus Ducateli Whitfield, 1594, Mon. xxiv, U. S. Geol. Survey, p. 67 (in part), pl. xi, figs. $4-\tilde{i}$.

Mercenarin plenc Whitfield, 189t, Mon. xxiv, U. S. Gieol. Survey, p. 69, pl, xij, figs. $4-6$.

Venus plenu Dall, 190\%, Trans. Wagner Free Inst. Sci., vol. iii, pt. vi, p. 1309.

Description.-- Cordate, inequilateral, ventricose, oblique, with close concentric rugose lines; posterior side subcuneiform; lunule ovate; inner margin densely crenulated.

". . . It approximates $M$. capax Conrad, but is shorter, less ventricose, more oblique; the hinge character differs, and the pallial sinus is deeper and more angular." Conrad, $18 \% 0$.

In the type specimen the shell is rather thin and very colvex or vaulted. The posterior end is not blunted as in $V$. capax. The hinge area in large specimens becomes broad and bears a striking resemblance to that of $V$. cuneata, as does also the general outline of the shell. It may be only the immature form or a variety of $V$. cuneata.

Length, $90 \mathrm{~mm}$. ; height, $78 \mathrm{~mm}$. ; diameter, $2 \% \mathrm{~mm}$.

Occurrence.-Сhoptank Formation. Governor Run, 2 miles south of Governor Run, Flag Pond, Jones Wharf, Pawpaw Point, Peach Blossom Creek, Dover Bridge, "Eastern Shore" (Cope). Calvert ForMation. Plum Point (Dall).

Collections.-Maryland Geological Survey, Johns Hopkins University, Academy of Natural Sciences of Philadelphia (type). 
Venus campechiensis var. tetrica (Conrad). Plate LXXX, Fig. 2, Plate LXXXI, Fig. 2.

Venus tetrica Conrad, 1838, Fossils of the Medial Tertiary, p. 7 , pl. iv, fig. 1. Mercenaria tetrice Conrad, 1863, Proc. Acad. Nat. Sci. Phila., vol. xiv, p. 574.

Mercenaria tetica Meek, 1\$64, Miocene Check List, Smith. Misc. Coll. (1\$3), p. 9. Tenus campechiensis Dall, 1903, Trans. Wagner Free Inst. Sci., vol. iii, pt. vi, pp. $1315,131 \%, 1318$ (in part).

Description. - "Shell triangular, cordate, ventricose, moderately thick, with crowded concentric very prominent laminæ; posterior side subcuneiform, extremity angulated; summits very prominent; lunule defined by a deeply impressed line.

"This shell has nearly the outline of $V$. mercenaria, but may be distinguished by its very prominent laminæ of nearly equal elevation on every portion of the disk." Conrad, 1838.

Length, $122 \mathrm{~mm}$. ; height, $100 \mathrm{~mm}$; diameter, $27 \mathrm{~mm}$.

Occurrence.-St. MarY's Formation. St. Mary's River.

Collections.-Maryland Geological Survey, Johns Hopkins T'nirersity.

Venus Campechiensis tar. mortoni (Conrad).

Plate LXXVII, Figs. 1, 2.

Venus _Tortoni Conrad, 1837, Jour. Acad. Nat. Sci. Phila., vol. vii, 1st ser., p. 251.

Venus Mortoni Conrad, 183s, Fossils of the Medial Tertiary, p. s, pl. v, fig. I.

Venus submortoni d'Orbigny, 1552, Prod. Pal. Strat., vol. iii, p. 108.

Mercenurin Mortoni Holmes, 1858, Post-Pleiocene Fossils of Sonth Carolina, p. 34, pl. vi, fig. 1:.

Mercentrit submortoni Conrad, 1863, Proc. Acad. Nat. Sci. Phila, vol. xiv, p. 574.

Mercenarit submortoni Heek, 1864, Miocene Check List, Smith. Misc. Coll. (183), p. 9.

Venus cumpechiensis DaII, 1903, Traus. Waguer Free Inst. Sci., vol. ii, pt. vi, pp. $1315,131 \%, 1318$ (in part).

Description.- "Shell cordate, inflated, thick and ponderous, with prominent recurved concentric laminæ, more elevated on the anterior and posterior margins; ligament margin arcuate; umbones prominent; lunule large, cordate, defined by a deep groove; posterior extremity slightly emarginate; cavity of the cartilage profound; teeth large, prominent, grooved; muscular impressions very large; inner margin regularly crenulated." Conrad, $183 \%$.

The shape and width of the hinge area and the elevation of the beak and general shape of the shell are much like var. cuneata of the older deposits at Jones Wharf. 
Length, $88 \mathrm{~mm}$; height, $7 \mathrm{~s} \mathrm{~mm}$. ; diameter, $27 \mathrm{~mm}$.

Occurrence.-St. Mary's Formation. St. Mary's River, Cove Point.

Collections.-Maryland Geological Survey, Johns Hopkins University.

Venus CAMPECHIENSis Var. CUNeata (Comrad).

Plate LXXXI1, Fig. 3, Plate LXXXIII, Fig. 2.

Mercemrir emente Conrad, 1565, Proc. Acad. Nat. Sei. Phila., vol. xix, p. 13s (name only).

Hercentrie cunente Conrad, 1s6s, Amer. Jour. Conch., vol, iv, p. 2is, pl. xx, fig. 1.

Vents compechiensis Dall, 1903, Trans. Waruer Free Inst. Sci., vol. iii, pt. vi, pl. $1315,131 \%, 13$ Is (in part).

Description.-." Subtriangular, ventricose medially, slightly flattened or contracted above the umbo; outline of the disk nearly straight below the middle; surface with coarse concentric lines; posterior side cuneiform, lower half of posterior margin nearly rectilinear, extremity subacute; inner margin minutely crenulated.

"This species may be distinguished from $M$. mercenaria in being less oblique, proportionally shorter and more acute at the posterior extremity, and in having a more elongated anterior cardinal tooth." Conrad, 1868.

This species is readily distinguished by its short, massive and broad hinge area, its great proportionate height, its massiveness, and its nearly symmetrical triangular outline. The dorsal and posterior slopes meet in an abrupt curve.

Length, $112 \mathrm{~mm}$; height, $102 \mathrm{~mm}$. ; diameter, $3 \% \mathrm{~mm}$.

Occurrence.-St. Mary's Formation. Cove Point, St. Mary's River. Choptank Formation. Governor Rum, 2 miles south of Governor Rum, Flag Pond, Jones Wharf, Pawpaw Point, Peach Blossom Creek, Dover Bridge, Greensboro, Cordova. Calvert Formation (?). Charles county (fide Cope).

Collections.-Maryland Geological Survey, Johns Hopkins University.

Venus Campechiensis tar. CApax (Conrad).

Plate LXXX, Fig. 1, Plate LXXXI, Fig. 1.

Temens copes Conrad, 1848 , Proc. Acad. Nat. Sci. Phila., vol. i, 1. 3:34.

Teums equmx Conrad, 18tin, Fossils of the Medial Tertiary, p. 6s, pl. xxxviii, fig. 4 .

Meremarie cupux Conrad, 1868 , Proc. Acad. Nat. Sci. Phila., vol. xiv, 1. irt.

Mercenarin crumx Meek, 186t, Miocene Cheek List, Smith. Misc. Coll. (1^3), p. 9.

I'enus cumpechienses Dall, 190:, loc. cit. supra.

Description._" Cordate, suborbicular, ventricose, with concentric lamelliform prominent lines; posterior margin curved, extremity trun- 
cated, direct, and remote from the line of the base; basal margin profoundly curved; lunule dilated, cordate, defined by a groove, and not distinctly impressed; inner margin finely crenulated.

"This shell is of a more rotund, tumid form than any of the species allied to $V$. mercenaria, and much more capacious; the lunule is shorter and wider." Conrad, 1843.

The markedly anterior position of the beak, the compact, rounded outline and the prominent, square truncation of the posterior extremity serve to distinguish this from other forms.

This variety is probably the ancestor of var. mortoni of the St. Mary's formation as it is practically indistinguishable from the young of that form.

Length, $62 \mathrm{~mm}$.; height, $43 \mathrm{~mm}$; diameter, $18 \mathrm{~mm}$.

Occurrence.-Choptank Formation. Governor Run, 2 miles south of Governor Run, Flag Pond, Jones Wharf, Turner, Pawpaw Point, Peach Blossom Creek, Cordova, Greensboro, Dover Bridge.

Collections.-Maryland Geological Survey, Jolnns Hopkins University.

Genus CHIONE Megerle von Mühlfeld.

Chione latilirata (Conrad).

Plate LXXVII, Figs. 3, 4, 5, 6.

Tenens lutilirate Courad, 18t1, Proc. Acad. Nat. Sci. Phila., vol. i, p. 2s

Not renus latilirata Tuomey and Holmes, 1856.

Veuns latilimtu Conrad, 18+5, Fossils of the Medial Tertiary, P. 68, Pl. xxxviii, tig. 3.

Circumplulus letilivutus Conrad, 1863, Proc. Acad. Nat. Sci. Phila., vol. xiv, p. 575.

Chione (Lirophora) latilirutu Meek, 186t, Miocene Check List, Smitb. Misc. Coll. (183), p. 9.

Chione (Lirophom) latilirutu Dall, 1908, Traus. Wagner Free Inst. Sci., vol. iif, pt. vi, p. 1:298, pl. xlii, tig. :3.

Description.- "Trigonal, convex depressed, ribs concentric, about 5 or 6 in number, flattened, reflected, irregular, one of them generally very wide; ribs irregularly sulcated on the posterior slope; inner margin finely crenulated. Smaller than I. alveata, and with broader, less prominent ribs, which do not diminish in size on the posterior margin." Conrad, $18 \pm 1$.

Often the reflected portion is broadly adherent or well plastered to the 
valve, and has a comparatively small groove beneath the reflected edge; ribs quite irregular in size and variable in number, usually about five.

Length, $23 \mathrm{~mm}$. : height, $18 \mathrm{~mm}$.; diameter, $6.5 \mathrm{~mm}$.

Occurrence.-Choptank Formation. Greensboro. Calvert Formation. Fairhaven, Chesapeake Beach, 3 miles south of Chesapeake Beach, Plum Point, Lyon's Creek, Reed's, Jewell.

Collections.-Mraryland Geological Survey, Johns Hopkins University.

Chione parkeria n. sp.

Plate LXXVI, Figs. 9, 10, 11.

Description.-Shell triangular, depressed, posteriorly somewhat cuneiform, anteriorly rounder; bealis projecting, acute, approximate; lunule distinct, cordate; base posteriorly emarginate; dorsal surface with about five to eight concentric ribs so perfectly flattened and closely appressed to the valve and each other as to become almost obsolete and be marked only by faint undulations and fine concentric impressed or laminated lines; ribs crossed from beak to base by numerous distinct, regular, radiating lines; cardinal teeth three in each valve; laterals none; muscle impressions deep; pallial sinus a slight notch; margin minutely crenulated. This species seems to be closely related to C. ulocyma Dall.

Length, $29 \mathrm{~mm}$; height, $23 \mathrm{~mm}$. ; diameter, $8 \mathrm{~mm}$.

Occurrence.-Calvert Formation. Parker Creek, 2 miles south of Parker Creek.

Collections.-Maryland Geological Survey, Johns Hopkins University.

Chione alveata (Conrad).

Plate LXXVI, Figs. 1, 2, 3.

Tenes alveuta Conrad, 1831 , Jour. Acad. Nat. Sci. Phila., vol. vi, 1st ser., p. :64, pl. xi, tigs. 14,15 .

Tenus aleeate Conrad, 1835, Fossils of the Medial Tertiary, p. 9, pl, v, tig. :.

Circumpluelus aleentes Conrad, 1863, Proc. Acad. Nat. Sci. Phila., vol. xiv, p. 575.

Chione (Lirophore) aleutus Meek, 1864, Miocene Check List, Smith. Misc. Coll. (183), 1. 9.

Chione (Lirophora) alveata Dall, 1903, Trans. Wagner Free Inst. Sci., vol. iii, pt. vi, p. 1298 .

Description.- " Shell subtriangular, thick, with about six, much elevated, very thick and profoundly reflected concentric ribs, remote, and 
becoming smaller towards the posterior end; margin crenulated." Con$\mathrm{rad}, 1831$.

Ribs well spaced, almost uniformly thin, but not uniformly recurred; deeply grooved beneath the recurved portion; beak profoundly curved anteriorly; muscle impressions small, subequal; pallial sinus a mere notch; marginal crenulation minute.

Length, $29 \mathrm{~mm}$. ; height, $26 \mathrm{~mm}$; diameter, $10 \mathrm{~mm}$.

Occurrence.-St. Mary's Formation. St. Mary's River.

Collections.-Maryland Geological Survey, Johns Hopkins University.

Subfamily MERETRICIN $Æ$.

Genus MACROCALLISTA Meek.

Macrocallista marylandica (Conrad).

Plate LXXIV, Figs. 1, 2.

Cytherea Marylandica Courad, 1833, A mer. Jour. Sci., vol. xxiii, p. 343.

Cytherea Marylandica Conrad, 1838, Fossils of the Medial Tertiary, p. 15, pl. ix, fig. 1.

Dione Ifarylandica Conrad, 1863, Proc. Acad. Nat. Sci. Phila., vol. xiv, p. 575.

Dione marylandica Meek, 1864, Miocene Check List, Smith. Misc. Coll. (183), p. 9.

Dione Marylandica Whitfield, 1894, Mou. xxiv, U. S. Geol. Survey, p. 74, pl. xiii, fig. 1.

IFacrocallista albaria Dall, 1903, Trans. Wagner Free Inst. Sci., vol. iii, pt. vi, p. 1253 (in part?).

Macrocallista (Chionella) marylandica Dall, 1903, Trans. Waguer Free Inst. Sci., vol. iii, pt. vi, p. 1255.

Description.-_" Shell obtusely ovate, smooth, thick; umbo obtusely rounded posteriorly; lunule ovate-acute and slightly impressed; hinge with the anterior tooth very robust." Conrad, 1833.

Shell thick, ponderous, moderately inflated; surface polished, crossed by faint concentric undulations; anterior extremity gently rounded, posterior extremity acutely rounded; hinge area ponderous; anterior muscle impression profound; pallial margin distinct; pallial sinus not profound.

The young of this species is much thinner, flatter and longer in proportion to the height than the adult forms, having in fact the shape of M. albaria, and in Maryland at least has often been called $M$. albaria. Whether M. albaria from Virginia be really merely the young of $M$. marylandica or not I have no means of telling. I know of no authentic specimens of $M$. albaria from Maryland. 
Length, $112 \mathrm{~mm}$. ; height, $90 \mathrm{~mm}$. ; diameter, $34 \mathrm{~mm}$.

Occurrence.-St. Marix's Foramation (?). Cove Point (?). Choptank Formation. Governor Run, 2 miles south of Governor Run, Flag Pond, Jones Wharf, 'Turner, Cuckold Creek, St. Leonard Creek, Dover Bridge, Peach Blossom Creek, Greensboro. Calvent Fonaration. Chesapeake Beach, 3 miles south of Chesapeake Beach, Plum Point, Church Hill.

Collections.-Maryland Geological Survey, Johns Hopkins University.

Genus CALLOCARDIA A. Adams.

Subgenus AGRIOPOMA Dall.

Callocardia (Agriopoma) subnasuta (Conrad).

Plate LXXV, Figs. 1, 2, 3.

Gytherea subuasuta Conrad, 1841, Proc. Acad. Nat. Sci. Phila., vol. i, p. 2s.

Cytherel subursute Conrad, 1S42, Jour. Acad. Nat. Sci. Phila., vol. viii, 1st ser., p. 183.

Cuthereu subnasuta Conrad, 1845, Fossils of the Medial Tertiary, p. 7\%, pl. xli, fig. 3. I'emes subnesuta d'Orbigny, 1852, Prod. Pal. Strat., vol, iii, p. 108, No. 2024.

Vems suburuta Tuomey and Holmes, 1556, Pleiocene Fossils of South Carolina, p. So, pl. xxi, fig. 3 .

Dione submasute Conrad, 1863, Proc. Acad. Nat. Sci. Phila, vol. xiv, p. 575.

Dione subutsuta Meek, 1864 , Miocene Check List, Smith. Misc. Coll. (183), p. 10.

Callocurdia (Agriopoma) subnusuta Dall, 1908, Trans. Wagner Free Inst. Sci., vol. iii, pt. vi, 1) 1264 .

Description.- "Trigonal, thin, ventricose; anterior side narrowed, slightly produced and subangulated at the extremity; surface with rather prominent concentric wrinkles; posterior margin obliquely arched; beaks distant from anterior extremity, and not nearly central; length $1 \frac{1}{8}$ inch. Allied to C. Sayana, but is proportionally longer, less ventricose, narrowed, and more produced anteriorly." Conrad, 1841.

See also remarks under $C$. sayana for additional distinctions between the two species.

Length, $30 \mathrm{~mm}$. ; height, $24 \mathrm{~mm}$. ; diameter, $8.5 \mathrm{~mm}$.

Occurrence.-St. Mary's Formation. Cove Point, Langley's Bluff, St. Mary's River. Choptank Formation. Jones Wharf, Dover Bridge, Calvert Formation. 3 miles south of Chesapeake Beach, Plum Point. Collections.-Maryland Geological Survey, Johns Hopkins University. 


\section{Callocardia (Agrioponja) prujexsis n. sp.}

Plate LXXV, Figs. 4, 5, 6.

Description.-Shell small, oval, convex or vaulted; heak elevated, projecting; anterior sicte nearly straight; anterior end regularly rounded; posterior side gently couvex; posterior end somewhat more acutely rounded than the anterior end; base regularly arched; teeth normal; carđinal area rather broad; ligament impressions and pallial sinus distinct; exterior polished, with a few shallow, concentric growth striæ here and there.

It differs from $C$. elevata H. C. Lea in its shape, in being polished and in lacking the gentle, irregular undulations or slight ridges characteristic of the elevata.

Occurrence.-Calvert Formation. Plum Point.

Collection.-Maryland Geological Survey.

\section{Callocardia (Agriopona) SaYaia (Conrad).}

Plate LXXIII, Figs. 13a, 14.

Cytheren conexa say, 1S24, Jour. Acad. Nat. Sci. Phila., vol. iv, 1st ser., p. 14!, pl. xii, tig. 3 ; not of Broguiart, 1811.

Cytherer Styanu Conrad, 1833, Amer. Jour. Sci., vol. xxiii, p. 345.

Cytherea Sayana Conrad, 1s38, Fossils of the Medial Tertiary, p. 13, pl. vii, tig. 3.

Cytheren comexu Gonld, 18+1, Invert. Mass., p. 84, fig. 49.

leuus Sayana d'Orbigny, 1852, Prod. Pal. Strat., vol. iii, p. 10S, No. 2011.

Venus suyum Tromey and Holmes, 1856, Pleiocene Fossils of Sonth Carolina, p. 83 , pl. xxi, tig. 9.

Cytheren Suyam Emmons, 1558, Rept. N. Car. Geol. Survey, p. 294, tig. 221.

Dione Sayum Conrad, 1863, Proc. Acad. Nat. Sci. Phila., vol. xir, p. 575.

Dione Sayana Meek, 1864, Miocene Check List, Smith. Misc. Coll. (183), p. 10.

Cytherea concexa Gould (Binney's), 1870, Invert. Mass., p. 131, fig. 444.

Dione Sayunu Whitfield, 1894 , Mon. xxir, U. S. Geol. Survey, p. 75 , pl. xii, tìg. 1.

Cullocerdia (Agriopoma) sayunu Dall, 1903, Trans. Wagner Free Inst. Sci., vol. iii, pt. vi, p. $1: 261$, pl. lvi, tig. 16.

Description. - Shell subcordate; elevated convex, concentrically wrinkled, inequilateral; posterior tooth and fosset not striated; edge not crenated; umbo rather prominent; lunule dilated, cordate, marked by a simple line." Say, 1824.

As compared with $C$. subnasuta, the only species with which it is apt to be confused, the sayana, has a thicker shell, is more highly conver, has a 
more projecting and more acute beak, is somewhat more acutely triangular in outline and within has a much more massive cardinal area and larger teeth.

Length, $40 \mathrm{~mm}$; height, $34 \mathrm{~mm}$; diameter, $12 \mathrm{~mm}$.

Occurrence.-St. Mary's Fonmation. Cove Point, St. Mary's River. Chioptank Formation. Jones Wharf, Peach Blossnm Creek.

Collection.-Maryland Geological Surrcy.

Genus CYTHEREA Bolton.

Subgenus ANTIGONA Schumacher.

Cytherea (Antigona) staminea Conrad.

Plate LXXVI, Figs. 6, r\%, 8.

Cytherea strminea Conrad, 183s, Fossils of the Medial Tertiary, p. 46 (name only).

Cytherea stuminea Conrad, 1539, Fossils of the Medial Tertiary, cover of No. 1, p. 3, pl. xxi, fig. 1.

Dione staminet Conrad, 1s68, Proc. Acad. Nat. Sci. Phila., vol. xir, p. 575.

Dione stuminea Meek, 1S64, Miocene Check List, Smith. Misc. Coll. (1S:3), p. 10.

Artena staminea Conrad, 1871, Amer. Jonr. Conch., vol. vi, p. 76.

Yenus (Artena) staminea Whitfield, 1894, Mon. xxiv, U. S. Geol. Survey, p. ro, pl. xiii, figs. $3-10$.

Cythered (Artena) staminea Dall, 1903, Traus. Wagner Free Inst. Sci,, vol. iii, pt. vi, p. 1279.

Description.- "Shell subtriangular, thick, with about ten very prominent acute slightly reflected concentric ribs, with an intermediate carina, and crowded minute lamellar striæ; anterior tooth very small; margin crenulated. Length 1 inch." Conrad, 1839.

Form compact, rounded, triangular; valves convex; beak not prominent; ribs perpendicular to the surface and at times as many as sixteen; posterior edge of dorsal slope often marked by a slight ridge causing a slight posterior basal emargination; cardinal teeth three in each valve; anterior lateral tooth in left valve very small and rounded and fitting into a correspondingly small socket in right valve; muscular impressions subequal; pallial sinus a mere notch.

Length, $27 \mathrm{~mm}$. ; height, $22 \mathrm{~mm}$. ; diameter, $8.5 \mathrm{~mm}$.

Occurrence.-Caldvert Formation. Chesapeake Beach, 3 miles south of Chesapeake Beach, Plum Point, Lyon's Creek, Reed's, Church Hill.

Collection.-Maryland Geological Survey. 


\section{Subfamily DOSINIINÆ.}

Genus DOSINIA Scopoli.

Dosinia acetabulum Conrad.

Plate LXXXIII, Fig. 1, Plate LXXXIY, Fig. 1.

Artemis acetubutum Conrad, 183:2, Fossil shells of the Tertiary, p. 20, pl. vi, fig. 1.

Artemis acetublum Conrad, 1838, Fossils of the Medial Tertiary, p. 29, pl. xvi, fig. 1.

Dosinia acetabultum Conrad, 1863, Proc. Acad. Nat. Sci. Phila, vol. xiv, p. $5 \pi 5$.

Dosinia acetabulum Neek, 1S64, Miocene Check List, Smith. Misc. Coll. (183), p. 10.

Dosinia wetubutum Whittield, 1894, Mon. xxiv, U. \&. Geol. Survey, p. 73, pl. xiil, fig. 2.

Dosinia (Dosinidia) ucetubulem Dall, 1903, Trans. Wagner Free Inst. Sci., vol. iii, pt. vi, p. 1230.

Description.- "Lentiform, with numerous concentric striæ, which are rather sharp and elevated on the anterior and posterior sides; cardinal fosset large, oblong, profound; with age, almost obliterating the posterior tooth; right valve with three teeth, the posterior one long and sulcated longitudinally; two anterior teeth approximate; left valve with four teeth, three of them distant; the anterior tooth somewhat pyramidal and entering a groove formed by two slight elevations in the opposite valve." Conrad, 1832 .

Length, $76 \mathrm{~mm}$. ; height, $77 \mathrm{~mm}$. ; diameter, $22 \mathrm{~mm}$.

Occurrence.-St. Mary's Formation. Cove Point, Langley's Bluff, St. Mary's River. Choptank Formation. Governor Run, 2 miles south of Governor Run, Flag Pond, Jones Wharf, Turner, Pawpaw Point, St. Leonard Creek, Sand Hill, Cordova, Greensboro, Trappe Landing, Peach Blossom Creek, Dover Bridge. Calvert Formation. 3 miles south of Chesapeake Beach, Plum Point, White's Landing, Lyon's Creek, Reed's.

Collections.-Maryland Geological Survey, Johns Hopkins University.

Genus CLEMENTIA Gray.

Clementia inoceriforums (Wagner).

Plate LXXXII, Figs. 1, 2.

Venus inoceriformis Wagner, 1839, Jour. Acad. Nat. Sci. Phila., vol. viii, 1st ser., p. 51 , pl. i, fig. 1 .

Tenus inoceriformis Conrad, 1845, Fossils of the Medial Tertiary, p. 70, pl. xl, fig. 1. Clementiu inoceriformis Conrad, 1863, Proc. Acad. Nat. Sci. Phila., vol. xir, p. 575. Clementia inoceriformis Meek, 1864, Miocene Check List, Smith. Misc. Coll. (1\$3), p. 10. 
Description.- "Shell oblique, suborbicular, thin and fragile, ventricose; disks with unequal, concentric undulations, forming prominent angulated carinæ; concentric striæ numerous, prominent; beaks prominent; no distinct lunule; cardinal teeth lamellar." Wagner, 1839.

Posterior hinge area marked by an angular ridge, posteriorly cuneiform and overlapping a deep, narrow groove and a shallow furrow rumning backward from the beak; concentric undulations prominent in interior of young thin shells; but obsolescent or obsolete in older thickened shells; pallial sinus large, profound and acutely teıminated.

Length, $61 \mathrm{~mm}$.; height, $64 \mathrm{~mm}$.; diameter, $19 \mathrm{~mm}$.

Occurrence.-St. Marr's Formation. Cove Point, St. Mary's River (fide Wagner). Choptank Formation. Governor Run, Sand Hill. Calvert Formation. Hollin Clift, Wye Mills, Plum Point (Dall).

Collections.-Maryland Geological Survey, Cornell University.

\section{Superfamily ISOCARDIACEA. \\ Family ISOCARDIIDÆ. \\ Genus ISOCARDIA Lamarck. \\ ISOCARDIA MARKö̈I Comrad. \\ Plate LXXXIV, Figs. 2, 3.}

Isocurdia Murkoëi Conrad, 1842, Proc. Nat. Inst., Bull. ii, p. 193, pl. ii, fig. 1 (right hand figures only and diagnosis in part).

Isocardia Mrorkof Conrad, 1845, Fossils of the Medial Tertiary, p. 70, pl. xl, fig. "z (right hand figures only and diaguosis in part).

Bucerdiu Murkoei Conrad, 1865, Proc. Acad. Nat. Sci. Phila., vol. siv, p. 5 б6.

Glossus Mrrkoci Meek, 1864, Miocene Check List, Smith. Misc. Coll. (1s:), p. S.

Isocardia Murkoei Dall, 1900, Trans. Wagner Free Inst. Sci., vol. iii, pt. v, p. 1067.

Description._" Suborbicular; length and height nearly equal; inflated; umbo very prominent, and the beaks profoundly incurved ; posterior mar. gin direct, arched above, nearly straight below, and obtusely angulated at its junction with the base; base regularly, not profoundly arched; posterior slope slightly sinuous." Conrad, $18+2$.

Conrad has figured in each case cited above two forms that on comparison of a number of specimens show constant differences, and his description applies partly to one and partly to the other. It becomes necessary, therefore, to restrict his name, and as the remarkable elevation and pro- 
found incurvature of the beaks seem to have been perhaps the most prominent characteristics in his mind-just as they produce the more striking of the two forms - the name $I$. markoëi will here be used to designate the species with highly elevated, narrow, prolonged, profoundly incurved beaks, a feature well represented in the right hand drawing of each of his figures. It is about as high as long; posterior margin quite or almost entirely arched; dorsal slope crossed by two or three broad, deep, concentrie undulations marking resting stages during growth.

Length, $48 \mathrm{~mm}$.; height, $46 \mathrm{~mm}$; diameter, $27 \mathrm{~mm}$.

Occurrence.-Calvent Foraration. Phum Point (rare).

Collection.-Marylend Geological Survey.

ISOCARD1A MAZLEA 12 . sp.

Plate JAXXIT, Figs. 4, 5.

Isocurdiu Ifrekoëi Conrad, 184؛, Proc. Nat. Inst., Bull, ii, p. 193, pl. ii, tig. 1 (left band drawing only and diagnosis in part).

Isocarliu Murkoei Conrad, 1\$45, Fossils of the Medial Tertiary, 1. 70, pl. xl, tig. : (left hand drawing only and diagnosis in part).

Description.-Shell rounded, inflated; length greater than height; umbo elevated, broad, short, only moderately incurved, not strongly projecting: dorsal slope crossed by several shallow and at times indistinct concentric undulations; posterior margin eurved above, straight below and meeting the base at an obtuse angle to which there extends a flattened ridge which is bordered on the posterior slope by a broad, gently depressed or grooved area. See also remarks under 1 . markiöi.

Length. $52 \mathrm{~mm}$; height, $46 \mathrm{~mm}$.; diameter, $2 \% \mathrm{~mm}$.

Occurrence.-Calvert Foranatox. Plum Point (rare).

Collection.-Maryland Geological Survey.

IsOcardia Fraterna Say.

Plate LXXXT, Figs. 3, 4.

Isocardin froterua Say, 18:24, Jour. Acad. Nat. Sci. Plila., vol, iv, 1st ser., p. 143, pl. xi, tig. 1 a aud b.

Iscourlir rustica Con rad, 1838, Fossils of the Medial Tertiary, p. 20, pl. xi, fig. 1.

Isocardie Comrali d'Orbigny, 1852, Prod. Pal. Strat., rol. ii, p. 1:21.

Glossus rusticus Conrad, 1854 , Proc. Acad. Nat. Sci. Phila., vol. vii, p. 29.

Bucordia freternu Conrad, 1863, Proc. Acad. Nat. Sci. Phila., vol. xiv, p. 5 r6. Glossus fraternu Meek, 1864, Miocene Check List, Smith. Misc. Coll. (18:3), 1\%. А.

Isocardia fiatema Dall, 1900, Trans. Wagner Free Inst. Sci., vol. iii, pt. v, p. 1066. 
Description.- "Cordate-globose, slightly oblique, with rather large concentric wrinkles, and lines of growth; an elevated undulation on the anterior submargin, marking the greatest length of the shell; umbones not very prominent, apex rather suddenly incurved, acute; impressed space behind the beaks, dilated and rather profound; anterior tooth striated externally, and placed on the middle of the anterior margin." Say, 1824.

Say had the anterior and posterior ends transposed so that for each reference to direction in the above description the opposite direction is to be understood. From the drawing and description, Say's large specimen was very probably a Virginia form. Specimens from Maryland are smaller and less rounded and have a more pronounced ridge and a basal angle where the dorsal and posterior slopes and margins meet. 'These differences seem constant but are not deemed of. sufficient importance to justify separating the Maryland forms from thase from Virginia.

Length, $73 \mathrm{~mm}$. ; height, $59 \mathrm{~mm}$. ; diameter, $29 \mathrm{~mm}$.

Occurrence.-St. Marís Formation. Cove Point (?), St. Mary's River. Choptank Formation. Governor limn, 2 miles south of Governor Run, Flag Pond, Jones Wharf, Pawpaw Point. Calvert FormaTION. Plum Point.

Collections.-Maryland Geological Survey, Jolns Hopkins University.

ISOCARDIA IGNOLEA n. sp.

Plate LXXXV, Figs. 1, 2.

Description.-Shell oval, moderately elevated anteriorly, gently depressed posteriorly; beak depressed, moderately incurved; surface of shell with numerous gentle, somewhat irregular, close-set, concentric mndulations most prominent on the marginal two-thirds of the surface; meeting of posterior and umbonal slopes marked by a ridge, of posterior and basal margins by an angle; posterior margin bluntly rounded; a cardinal and a posterior lateral tooth in left valve, two cardinals in right valve; ligament area curved, ridged, and grooved; interior smooth; muscle impressions and pallial margin distinct.

It is unfortunate that the locality from which this species comes is in some doubt. The only specimens - the two valves of the same individual-were found in a case of University material from Cove Point, but the color of the weathering, state of preservation, and incrusting material 
seem more characteristic of Plum Point than of Cove Point, so that while I am inclined to believe them to be from the latter place, the matter must be left undecided until further search shall perhaps reveal other specimens at one locality or the other.

Length, $67 \mathrm{~mm}$. ; height, $47 \mathrm{~mm}$. ; diameter, $26 \mathrm{~mm}$.

Occurrence.-ST. Mary's Formation. Cove Point (see above). Collection.-Johns Hopkins University.

\section{Superfamily CARDIACEA. \\ Family CARDIIDÆ. \\ Genus CARDIUM Linné. \\ Subgenus CERASTODERMA Mörch.}

Cardium (Cerastoderaia) l.aqueatum Conrad.

Plate LXXXVI, Fig. 1.

Curdium luqueutuin Conrad, 1831, Jour. Acad. Nat. Sci. Phila., vol. vi, 1st ser., p. 255 .

Cardium laqueutum Conrad, 1838, Fossils of the Medial Tertiary, p. 31, pl. xvii, tig. 1.

Curdium ingens Wagner, 1839, Dall, 1598, Trans. Wagner Free Inst. Sci., vol. v, p. 10, pl, iii, fig. 2 .

Curdium (Cerestoderma) lequeutum Conrad, 1863, Proc. Acad. Nat. Sci. Phila., vol. xiv, p. $5 \% 6$.

Curdium (Cerastoderma) laqueatum Meek, 1564 , Miocene Check List, Smith. Misc. Coll. (183), p. 9.

Cardium (Cerastoderma) laquentum Dall, 1900, Trans. Wagner Free Inst. Sci., vol. iii, pt. v, p. 109:.

Description.- "Shell cordate, ventricose, thin, with about 33 subtriangular, transversely wrinkled ribs; umbones prominent; lunule not profoundly impressed and somewhat lanceolate; cardinal tooth subulate." Conrad, 1831.

The ribs vary in number from thirty-three to thirty-six. The number given in description published in 1838 (forty-three) is doubtless an error in copying. Cardinal tooth prominent, lateral teeth distinct; anterior and posterior muscle impressions and pallial line distinct; margin strongly dentate in harmony with the ribbing; shell almost always broken and so perfect specimens are rare.

Length, $116 \mathrm{~mm}$. ; height, $97 \mathrm{~mm}$. ; diameter, $38 \mathrm{~mm}$. 
Occurrence.-St. Mars's Formation. Cove Point, Langley's Bluff, St. Mary's River. Choptank Formation. Governor Run, 2 miles south of Goveruor Rum, Flag Pond, Jones Wharf, Turner, Pawpaw Point, Cuckold Creek, St. Leonard Creek, Dover Bridge, Greensboro, Sand Hill. Collections.-Maryland Geological Survey, Johns Hopkins University.

\section{Cardium (Cerastoderma) leptopleurum Conrad. \\ Plate LXXXVI, Fig. 2.}

Conclime leptoplenru Conrad, 1841, Proc. Acad. Nat. Sci. Phila., vol. i, p. 29.

Curdium leptopleur Conrad, 1842, Jour. Acad. Nat. Sci. Phila., vol. viii, 1st ser., p. 184.

Curlium leptopleum Conrad, 1845, Fossils of the Medial Tertiary, p. 66, pl. xxxvii, fig. 5.

Cardimm (Cerustoderma) leptoplenra Conrad, 1863, Proc. Acad. Nat. Sci. Phila., vol. xiv, p. $5 \% 6$.

Cardium (Cerastoderma) leplopleur Meek, 1864, Miocene Check List, Smith. Misc. Coll. (183), 1). 9.

Cardium (Cerustodermu) leptopleura Dali, 1900, Trans. Wagner Free Inst. Sci, vol. iii, pt. r, 1095 .

Description._"Subtrigonal, rentricose; ribs about 31 , prominent, distant, angular, carinater ; umbo prominent, oblique; lateral teeth very prominent; inner margin widely and deeply creuate." Conrad, $18+1$.

Ribs vary in number from twenty-eight to thirty-one; in transverse section, profile of each rib rounded and as broad across the base as tall, becoming in older specimens eren broader and more flatly rounded or even flat: distance from beak to base rather short as compared with length of shell; hinge line proportionally long:

Length. $48 \mathrm{~mm}$; height, $4 \% \mathrm{~mm}$. ; diameter, $17 \mathrm{~mm}$.

Occurrence-Calvert Foratatiox. Plum Point, near Jewell (rare). Collections.-Maryland Geological Survey, U. S. National Musemm.

Cardium (Cerastoderma) craticuloide Conrad.

Plate LXXXV1, Fig. 3.

Curdium creticuloides Conrad, 1845, Fossils of the Medial Tertiary, p. 66, pl. xxxvii, fig. 3 .

Curdium (Cesustudermu) erutiruloides Conrad, 1863, Proc. Acad. Nat. Sci. Phila, vol. xiv, p. 5iti.

Curdimm (Cerustodermu) rmticuloides Meek, 1864, Miocene Check List, Smith. Misc. Coll. (183), p.s.

Curdium (Cerastodermu) couticmloides Whitfield, 1894, Mon. xxir, U. S. Genl. Survey, p. 66, pl. $x$, figs. $16-19$. 
Description.-."Suborbicular, ventricose; ribs about 29, very much compressed, profoundly elevated, the summits reflected on both sides, consequently the ribs are as wide on the back as at base; summit of the umbo very prominent.

"Remarkable for the compressed form and great eleration of the ribs which are most remote on the anterior side; ribs not very regular, but somewhat sinuous." Conrad, $18+5$.

Ribs sometimes as many as thirty-two, in transverse section anginlar, very narrow, highly elevated, and wider on top than just beneath; distance from beak to base proportionally greater as compared with length than in $C$. leptopleurum; hinge line proportionally short; shell thin, easily broken; beaks approximate.

Length, $52 \mathrm{~mm}$.; height, $62 \mathrm{~mm}$; diameter, $18 \mathrm{~mm}$.

Occurrence.-CaLvert Forication. 3 miles south of Chesapeake Beach, Plum Point (rare).

Collection.-Maryland Geological Survey.

\section{Cardium (Cerastoderala) calvertensiuar n. sp.}

Plate LXXXVI, Fig. 4.

Description.-Shell elevated, rounded; beak prominent; ribs seventeen to twenty-two, rounded, rather distant, the interspaces as broad as, or broader than, the ribs; on anterior and posterior dorsal submargin ribs small to almost obsolete; entire interior of shell strongly grooved in harmony with the ribbing; cardinal and lateral teeth small, not prominent.

It may be readily distinguished from other species by its much fewer ribs, rounded form, strong internal grooving and small teeth. It is abundant as casts in the basal clays, but is very rare in the later deposits of the Miocene.

Length of shell broken along growth line, $3 \% \mathrm{~mm}$; height, $38 \mathrm{~mm}$.; diameter, $14 \mathrm{~mm}$.

Occurrence.-Calvert Fonmation. Fairhaven, Plum Point, Gorernor Run (at base of cliff), White's Landing.

Collection.--Maryland Geological Survey. 


\section{Cardium (Cerastoderma) patuxentium n. $\mathrm{sp}$.}

Plate LXXXVI, Fig. 5.

Description.-Shell large, moderately thick, elevated; beak elevated, prominent; ribs fine, rounded to flattened, close set and separated by a narrow groove, normally fifty-two or somewhat more-one specimen with but forty-five; cardinal tooth strong, elevated;'lateral teeth prominent; interior smooth; interior margin not known.

This species may be easily distinguished by its large number of ribs.

Approximate measurements are: length, $55 \mathrm{~mm}$; height, $50 \mathrm{~mm}$; dianeter, $20 \mathrm{~mm}$.

Occurrence.-Calvert Formation. Truman's Wharf, White's Landing (as well-preserved casts of the exterior in the siliceous beds), New Town, Wye Mills.

Collection.-Maryland Geological Survey.

Subgenus FRAGUM Botten.

Cardiuar (Fragum) medium Linné.

Plate LXXXVI, Figs. 6a, 6b.

Cardium medium Linné, 1758, syst. Nat., ed. x, p. 678.

Cưdium medium Linué, 1768, Syst. Nat., ed. xii, p. 1122.

Hemiandium eolumbe Heilprin, 1887, Trans. Wagner Free Inst. Sci., vol. i, 1. 95, pl. xi, fig. 26.

Curdium (Frengun) medium Dall, 1900, Trans. Wagner Free Inst. Sci., vol. iii, pt. v, 1. 1101.

Description.- "C. testa subcordata subangulata; valvulis angulatis sulcatis lævibus." Linné, 1758.

This species is distinguished by the amount of impression of the posterior area and the elevation of the upper part of the posterior margin projecting from the central part of the depression of the closed valve. The amount of depression varies very much and the range of variation is so complete that this characteristic is difficult to rely upon.

The Pliocene form of this species was deseribed by Professor Heilprin as Hemicardium columba. He had only two specimens and they happen to be end members of the gradation series.

Occurrence.-St. Mary's Formation. St. Mary's River.

Collection-U. S. National Museum. 
Subgenus LÆVICARDIUM Swainson.

Cardiuli (Levicardium) mortoni Conrat.

Plate LXXXVI, Figs. \%a, \%b.

Cardium Mortoni Conrad, 1831, Jour. Acad. Nat. Sci. Phila., vol. vi, 1st ser., p. 259, pl. $x$, figs. 5, 6, 7 .

Cardium Mortoni Gould, 1841, Invert. Mass., p. 91.

Liocardinm Mortoni Stimpson, 1860, Check List E. Coast Shells, p. 2.

Levicardium Mortoni Perkins, 1869, Proc. Bost. Soc. Nat. Hist., vol. xiii, p. 150.

Liocardium Mortoni Dall, 1889, Bull, xxxvii, U. S. Nat. Mrus., p. 54, pl. lviii, tig. 8. Cudium (Lrevicardinin) Mortoni Dall, 1900, Trans. Wagner Free Inst. Sci., vol. iii, pt. v, p. 1111.

Description._." Shell subovate, oblique, slightly" rentricose, thin, destitute of ribs or radiating striæ; white, covered with a pale brown epidermis darker towards the base and wrirkled at the ends; within striated, and of a yellow colour; margin entire or obsoletely serrated, whitish, with generally an oblong black or dark purple spot on the posterior side.

"This shell has not the polish nor distinctly serrated margin of $C$. serratum to which it is nearly allied; the striæ are occasionally obsolete or only slightly serrate: the margins towards the anterior end, and the young shells are marked with angular fulvous spots, similar to the young of C. lavigatum and several other shells." Conrad, 1831.

Occurrence.-Choptank Fonmation. Jones Wharf (fide Dall).

Collection.-U. S. National Museum.

\section{Superfamily LEPTONACEA.}

Family GALEOMMATIDÆ.

Genus SOLECARDIA Conrad.

Subgenus SPANIORINUS Dall.

Solecardia (Spantorinus) cossmanni Dall.

Plate LXXXVII, Figs. 1, 1a, 2, 3, 4.

Solecardiu (Spaniorinns) Cossmumi Dall, 1900, Trans. Wagner Free Inst. Sci,, vol, iii, pt. v, p. 1125, pl, xlv, figs. 27, 27a.

Description.- " Shell thin, nearly equilateral, rounded at both ends, the posterior end blunter, shorter, and higher than the anterior; surface with rather irregular obvious incremental lines, smoother near the 
beaks; base nearly straight, posterior dorsal slope arcuate, descending; anterior arcuate. beaks low, inconspicnous; right valve with the tooth narrow. slender, in a transwerse rertical plane, the anterior dorsal margin expanded slightly just in front of it, the sear of the resilium strong, narrow, oblique: left valve with the toorh flattened in a horizontal plane, the anterior part longer; interior with faint, obsolete radiations: adductor scars rather large, ovate: margins entire." Dali. 1900 .

Length, 8 mm.: height, 5 $11 m$.

Occurrence.-St. Mary Forantios. Cove Point. Choptaxk Formation. 2 miles south of Governor Run. Calnert Formation. Plum Point.

Collection.-Maryland Geological Survey.

Family SPORTELLIDÆ.

Genus SPORTELLA Deshayes.

SPortella whitfieldi Dall.

Plate LXXXVII, Figs. 5a, 5b.

Syndosinga? nuculoides Whitfield, 1894, Mon. xxiv, U. S. Geol. Survey, p. s1, pl. xr, figs. $\mathbf{7}-\mathbf{9}$; not of Courad.

Sportella Whitfieldi Dall, 1900, Trans. Wagner Free Inst. sci., vol. iii, pt. v, p. 1128.

Description. - "The shell is rather elongate-ovate, and moderately convex, and extremely thin and delicate in texture. The beak is small, situated rather within the anterior third of the length, behind which the shell is narrowed, the fosterior end being more narrowly rounded than the anterior; basal and cardinal margins subparallel; surface with rery fine concentric lines only, and with a very faintly defined, oblique, mesial sulcns. Internally there is a single, moderately strong, direct tooth beneath the beak, with a deep, wirle pit in front, in the right valve, and a slight projecting lamellar tooth near its extrenity. No appearance of a posterior lateral tooth can be seen. Muscular imprints very faint, and a pallial sinus shallow and obscure. It is not an Abra, as there are no lateral teeth." Whitfield, 1894.

Length, $7.9 \mathrm{~mm}$.; height, $5 \mathrm{~mm}$.

Occurrence.-Calnert Foruation. Plum Point.

Collection.-Maryland Geological Survey. 


\section{SPortella PELex Dall.}

Plate LXIXYII, Fig. 6.

Sportella pelex Dall, 1900, Trans. Wagner Free Inst. Sci, vol. iii, pt. v, p. 1131, pl. xliv, fig. 10 .

Description. - "Shell small, solid, compressed, inequilateral, the posterior side quite short and blunt; beaks low, surface seulptured with fine, regular incremental lines, of which a few at wide intervals are more conspicuous; basal margin nearly straight, anterior end produced, rounded, posterior bluntly rounded; left ralve with a strong hinge, the anterior lamella obsolete, but the one behind it prominent and strong, socket of the resilimm deep, the hinge plate above it obscurely thickened, a narrow but distinct groove for the external ligament; interior polished, the adductor sears rather high up, the disk faintly radially striated, the margin entire.

"This species has a good deal the shape of a small Mesodesma and is nearest to $S$. yorkensis, compared with which it is higher and more inequilateral and with a more ol,Iique anterior dorsal slope." Dall, 1900.

Length, $\% .3 \mathrm{~mm}$.; height, $5.5 \mathrm{~mm}$.; diameter, 2 mm. (Dall).

Occurrence.-St. Marr's Foratition. St Mai'y's River.

Collection.-Maryland Geological Survey.

\section{Sportelat petropolitana Dall.}

Plate LXXXTII, Fig. \%.

Sportella petropolitana Dall, 1900, Trans. Wagner Free Inst. Sci., vol. iii, pt. v, p. 1130 , pl. xlv, fig. 10.

Description._- Shell small, oblong, subequilateral, moderately convex, the dorsal slopes evenly arched, the base ncarly straight, and the ends rounded; beaks low and inconspicuous; outer surface nearly smooth or senlptured with incremental lines: hinge with the cardinal tooth single, smooth and conical, the pit small, triangular, and the ligamentary ridge obscure. Lon. 5.75, alt. 3.75, dian. 2 mm." Dall, 1900.

Occurrence.-Camert Formation. Plum Point.

Collection.-U. S. National Museum. 


\section{SHORTELLA RECESSA n. sp.}

Plate LXXXVII, Figs. 8, 9, 10.

Description.-Shell blunted-ovate, not greatly infiated; inequilateral, anterior part the longer; beak slightly projecting; anterior dorsal margin nearly straight, posterior one curved; posterior end more blunted than anterior one; basal margin gently eurved; pallial line faint; addnctor scars very faint, anterior one elongated, posterior one more rounded; external surface with fine, irregular, concentric, incremental lines.

Length, $4.6 \mathrm{~mm}$.; height. $3.8 \mathrm{~mm}$.; diameter, $1.1 \mathrm{~mm}$.

Occurrence.-St. Mary's Formation. Cove Point. Calvert ForMATION. Reed's.

Collection.-Maryland Geological Survey.

\section{SPORTELLA PATUXENTIA n. sp.}

Plate LXXXVII, Fig. 11.

Description.-Shell triangular, depressed. thick, inequilateral; anterior side the longer; anterior side declining, slightly curved; anterior end acutely rounded; posterior side very short; posterior end bluntly rounded; teeth strong; muscle impressions distinct; anterior one elongated and narrow, posterior one rounded; pallial line distinct, ragged, somewhat irregular; exterior surface with irregular concentric lines or grooves.

Length, $8 \mathrm{~mm}$; height, $6 \mathrm{~mm}$; diameter, $1.65 \mathrm{~mm}$.

Occurrence.-St. MarY's Fonmatiox. Cove Point.

Collection.-Maryland Geological Survey.

Genus HINDSIELLA Stoliczka.

IIINDsiella ACUTA Dall.

Plate LXXXT11, Figs. 12a, 12b, 13.

Hindsielle achta Dall, 1900, Trans. Wagner Free Inst. Sci., vol. iii, pt. v, p. 1138, pl. xlv, fig. 9.

Description._. Shell small, cuneate, inflated, subequilateral, the posterior side broader and rounded, the anterior narrower, more pointed and decurved; anterior dorsal margin declining. posterior areuate; 
middle of the base conspicuously insinuate; surface sculptured with crowded, rather prominent incremental lines, feebler towards the anterior end, which shows some faint radial markings; hinge-plate narrow, left valve with a prominent subumbonal tooth and a feeble lamella a little in front of it, a strong resiliary scar, and a minute, obsolete, very distant posterior lamella; right valve with an arcuate, short, umbonal lamina, a deep pit for the opposite cardinal above it, and a short, distant, sharp groove corresponding to the posterior lamella of the opposite valve; interior of the valves polished, faintly radially striate, the adductor scars rather low down.

"This species is especially characterized by its relatively acute anterior end, which, in all the individual variations noted, is still preserved." Dall, 1900.

Length, $6 \mathrm{~mm}$.; height, $4 \mathrm{~mm}$.: diameter, $3 \mathrm{~mm}$ (Dall).

Occurrence.-St. Maru's Formation. St. Mary's River.

Collection.-Maryland Geological Survey.

\section{Family LEPTONIDÆ.}

Genus ERYCINA Lamarck.

Ertoina Caltertensis n. sp.

Plate LXXXVII, Fig. 16

Description.- Shell nearly orate, base well arched and meeting posterior margin in a curve above the line of the base; anterior side slightly prochuced, beak rather prominent; anterior and posterior dorsal margins declining from the beak at an obtuse angle; teeth prominent; interior with muscle impressions and pallial line distinct; exterior smooth; shell depressed, thin.

Length, $4 \mathrm{~mm}$.: height, $3 \mathrm{~mm}$; diameter. $0.8 \mathrm{~mm}$.

Occurrence.-Cilvert Fonmation. Plum Point.

Collection.-U. S. National Museum.

ERTCINA PRUNA n. sp.

Plate LXXXVII, Fig. 1\%.

Description.--Shell small, short, ovate, depressed; beak slightly projecting; inequilateral, anterior end the longer; anterior and posterior 
sides and ends forming with the base regular curves; anterior end more acutely rounded and narrower than posterior one; lateral lamellæ short, strong and standing ont from the linge area well into the interior of the shell; lateral grooves short and deep; ligament impressions high up and elongated, the posterior being the larger and broader; pallial line indistinct; onter surface with light, meven concentric lines and here and there a deeper, stronger groove marking, perhaps, a resting stage.

Length, $4.5 \mathrm{~mm}$.; height. $3.8 \mathrm{~mm}$; diameter, $0.9 \mathrm{~mm}$.

Occurrence.-Calvert Formation. Plum Point.

Collection.-Maryland Geological Survey.

Ertcina Marthandica n. sp.

Plate IXXXYIII, Figs. 1, 2, 3.

Description.- Shell small, ovate, depressed, beak very low; anterior and posterior sides straight near the beak and meeting in an angle there; anterior end regularly rounded: posterior end blunted; base regularly arched; lateral lamella distinct, rather long; posterior adductor sear rounded and not so high up as the narrower, elongated anterior one; pallial line well away from the margin; onter surface with irregular, concentric grooves or undulations here and there stronger than elsewhere.

Length, $3.9 \mathrm{~mm}$; height, $3.1 \mathrm{~mm}$.; diameter, $0.9 \mathrm{~mm}$.

Occurrence.-CaLVERT Formation. 3 miles south of Chesapeake Beach, Plum Point.

Collection.-Maryland Geological Survey.

ERTCINA RICKARDIA n. sp.

Plate LXYXVIII, Figs. 4a, $4 \mathrm{~b}$.

Description.- Shell ovate-quadrate, thick, depressed; beak low but projecting slightly; rery inequilateral, the anterior side being much the longer; anterior side concave near the beak; anterior end bluntly rounded, its curve being continuous with the base; posterior side and end a regular curve meeting the base at an angle and on a line with the base lateral laminæ and grooves quite prominent: adductor scars distinct, the anterior one the higher up; pallial line rather broad and 
remote from the basal margin; outer surface ornamented with fine, regular, close set concentric grooves, the narrow ridges between being rounded.

Length, $6.25 \mathrm{~mm}$; height. $5.1 \mathrm{~mm}$; diameter, $1 \mathrm{~mm}$.

Occurrence.-Calvert Foracition. Plum Point.

Collection.-Cornell University.

\section{ERYCINA SPECIOSA n. sp. \\ Plate LXXXYIII, Fig. 5.}

Description.- Shell almost elliptically rounded, sare for the slight projection of the beak; anterior end slightly longer; anterior basal margin slightly prolonged before curving upward; shell flattened with a lenticular slope or surface curvature near margins; teeth very strong and prominent, projecting: exterior smooth; interior polished.

Length, 4 mm.; height, $3.2 \mathrm{~mm}$; diameter, $0.9 \mathrm{~mm}$.

Occurrence.-Choptaxk Formation. Governor Run. Calrert ForMation. Plum Point.

Collections.-Maryland Creological Survey, U. S. National Museum.

\section{Subgenus PSEUDOPYTHINA Fischer.}

Erycina (Pseudoptithina?) AMERichina Dall.

Plate LXXYVII, Figs. 14, 15.

Erycind (Isendopythind ?) americane Dall, 1900, Trans. Wagner Free Inst. Sci., vol. iii, pt. r, p. 1146, pl. xliv, figs. $21,25$.

Description.- "Shell large, moderately convex, inequilateral, rounded at both ends, the posterior side shorter; beaks low, surface sculptured only with rather conspicuous incremental lines: anterior dorsal margin nearly parallel with the base, posterior dorsal margin arcuate: hingemargin narrow, feebly chamnelled, edentulous, adductor scars small, narrow, high up; pallial line wide and radially striated." Dall, 1900.

Length, $16 \mathrm{~mm}$; height, $10.5 \mathrm{~mm}$; diameter, \% $\mathrm{mm}$.

Occurrence.-Calvert Forination. "Calvert Cliffs" (= Plum Point?), (Burns).

Collection.-U. S. National Museum. 
Genus BORNIA Philippi.

BorNia MACTROIDES (Conrad).

Plate TXXXVIII, Figs. 6, \%, 8.

Lepton mectmides Conrad, 1854, Jour. Acad. Nat. Sci. Phila. vol, vii, 1st ser., p. 151.

Lepton mectroides Conrad, 1838 , Fossils of the Medial Tertiary, p. 19, pl. x, tig. 5.

Leptom mutroides Conrad, 1863, Proc. Acad. Nat. Sci. Phila., rol, xiv, p. 57 .

Lepton murtivides Meek, 1864, Miocene Check List, Smith. Misc. Coll. (183), p. S.

Borniu matroides Dall, 1900, Trans. Wagner Free Inst. Sci., vol. iii, pt. v, p. 1150.

Description._- Shell triangtlar, subequilateral, thin, convex, smooth and polished; beaks prominent; central; basal margin straight; posterior extremity less obtusely rounded than the anterior. Length less than half an inch." Conrad, 1834.

Length, $10 \mathrm{~mm}$.; height, $7.2 \mathrm{~mm}$; ; diameter, $2 \mathrm{~mm}$.

Occurrence.-Choptank Fonstion. Governor Run, 2 miles south of Governor Rum, Jones Wharf, Peach Blossom Creek, Dover Bridge.

Collections.-Maryland Geological Survey, Tohns Hopkins University.

Bornia TRIANGULA Dall.

Plate LXXXVIII, Figs. 9a, 9b.

Kellia triangula H. C. Lea, MS., in Coll. Acad. Nat. Sci. Phila.

Bornia triangula n. sp. ? Dall, 1900, Trans. Wagner Free Inst. Sci., vol. iii, pt. v, p. 1151.

Description.-- Shell compact, elevated, triangular; anterior and posterior dorsal margins declining at an obtuse angle from the beak; beak distinctly prosocolous and situated anterior to the middle of the shell; anterior and posterior margins rounded: shell inflated just beneath the beaks but mesially compressed near the basal margin; teeth distinct, shell thin, polished; faint growth lines visible.

Length, $5 \mathrm{~mm}$.; height. $4.45 \mathrm{~mm}$.

Occurrence.-Chlovert Foruntion. 3 miles west of Centerville.

Collection.-Maryland Geological Survey.

BORNIA MARTLANDICA n. sp.

Plate LXXXVII, Fig. 10.

Description.-Shell triangular depressed; inflated dorsally; gently compressed mesially near basal margin; beak low, very markedly proso- 
cœlous; anterior dorsal margin direct, declining; posterior dorsal margin strongly arched or rounded; anterior side rounded cuneate; posterior side longer, more inflated and ovate; posterior end slightly truncate; teeth prominent; muscle impressions and pallial line distinct; interior radial striæ distinct, especially near basal margin; exterior polished; basal margin direct.

Length, 8 mm.; height, r mm.; diameter, $1 . \approx \mathrm{mm}$.

Occurrence.-Choptaxk Formation. Greensboro. Calverí Formation. Plum Point (U. S. National Museum).

Collections.-Maryland Geological Survey, U. S. National Musemm.

Bornia DEPRESSA n. sp.

Plate LXXXYIII, Fig. 11.

Description.-Shell rounded ovate; anterior side slightly produced; anterior end somewhat more sharply rounded than posterior end; base very gently curved; beak not prominent, rising very little above profile of dorsal margin; shell thin and only moderately convex; outer surface smooth, inner surface with rery distinct muscle impressions and pallial line; teeth prominent, anterior one set almost transverse to hinge line, posterior one more declining.

Length, $4.6 \mathrm{~mm}$; height, $3.2 \mathrm{~mm}$; diameter, $0.9 \mathrm{~mm}$.

Occurrence.-Calvert Formation. Plum Point.

Collection.-U. S. National Musenm.

Genus KELLIA Turton.

KELLiA ROTUNDULA n. sp.

Plate LIXXVIII, Figs. 12, 13.

? Kellia sp. indet. Dall, 1900, Trans. Wagner Free Inst. Sci., vol. iii, pt. v, p. 1154.

Description.-Shell delicate, rounded, elliptical: highly inflated; beak almost medial, not prominent; posterior end slightly truncated squarely; binge area prominent; teeth distinct, moderately stout; muscle impressions and pallial line faint; faint interior radial markings visible; exterior polished, smooth.

Length, $7 \mathrm{~mm}$; height, $6 \mathrm{~mm}$; diameter, $1.4 \mathrm{~mm}$. 
Occurrence.-Сhoptank Fondation. Governor Run, Dover Bridge (?) (Dall).

Collections.-Maryland Geological survey, U. S. National Museum (?).

Cenus THECODONTA A. Adams.

Subgenus DICRANODESMA Dall.

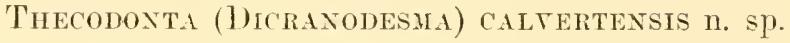

Plate LXXXTII, Figs. 14, 15, 16, 1\%, 18.

Therodontu! (Dicranodesma) culvertensis (Glenn) Dall, 1900, Trans. Wagner Free Inst. Sci., vol, iii, pt. v, p. 1157 , pl, xlv, tigs. 23, 24, listed.

Description.- Shell compact, stout, ovate-triangular, vaulted, very inequilateral; beak acute, slightly projecting and very far anterior; anterior side and end continuous, nearly straight above but meeting the base in a regular curve; posterior side slightly convex; posterior end rounded; base gently curved; musele impressions rounded, small, nearly equal in size and situated high up; pallial line broad and ragged; exterior polished, with fine, faint, irregular, concentric growth strix or with stronger, more remote, concentric undulations; hinge strong, broad; teeth, anterior conical, posterior flattened.

Length, $4.6 \mathrm{~mm}$. : height, $3.5 \mathrm{~mm}$.; diameter, $1.2 \mathrm{~mm}$.

Occurrence.-Calvert Formation. Plum Point.

Collection.-Maryland Geological Survey.

Genus MONTACUTA Turton.

Montacuta Mariana Dall.

Plate LXXXVIII, Fig. 19.

Montacuta meriane Dall, 1900, Trans. Wagner Free Inst. Sci., vol, iii, pt. v, p. 1173, pl. xly, tig. 18.

Description.-"Shell small, ovate, moderately convex, sculptured chicfly by ineremental lines and faint coneentric wrinkles; beaks conspicuous, showing the prodissoconch, but not high, nearly central, the dorsal margin sloping almost equally each way from the beaks, the ends rounded, the base evenly arcuate; hinge with a single, small, subtrigonal anterior lamina in each valve, a small, oblique submarginal sulcus in each valve behind the beaks; interior of the ralves smooth. muscular impressions faint but normal." Dall, 1900. 
Length, $4 \mathrm{~mm}$; height. $3.25 \mathrm{~mm}$.; diameter, $1.5 \mathrm{~mm}$.

Occurrence.-ST. Marr's Formation. St. Mary's River. Calrert Foricatiox. Plum Point.

- Collections.-U. S. National Museum, Maryland Geolngical Survey.

Genus Aligena H. C. Lea.

Aligexa equata (Comrad).

Plate LXXXVIII, Figs. 20, 21: Plate LXXXIX, Figs. 1, 2a, 2b, 3.

Amphidesma requeta Conrad, 1843, Proc. Acad. Nat. Sci. Phila., vol. i, p. 307.

Amphidesma requeta Conrad, 1845, Fossils of the Hedial Tertiary, 1. 65, pl. xxxvi, fig. 5.

Aligeru striute H. C. Lea, 1845, Trans. Amer. Philos. Soc., vol. ix, p. 238, pl. xxxir, fig. 13.

Amphidesma cequet Tuomey and IIolmes, 1856, Pleiocene Fossils of South Carolina, p. 95, pl. xxiii, fig. 5 .

Abru cequete Conrad, 1863, Proc. Acad. Nat. Sci. Phila., vol. xiv, p. 574.

Abre cequatu Mleek, 1864, Miocene Check List, Smith. Mise. Coll. (18:3), p. 11.

Aligene requatu Dall, 1898, Trans. Wagner Free Inst. Sci., vol. iii, pt. iv, pl. xxiv, tigs. $8,8 \mathrm{a}, 8 \mathrm{~b}$.

Aligene requate Dall, 1900, Trans. Wagner Free Inst. Sci., vol. iii, pt. v, p. 1175.

Description.- " Longitudinally oval, convex, with about 17 laminated concentric striæ; anterior and posterior margins nearly equally rounded; basal margin very regularly rounded; beaks slightly prominent; one cardinal tooth in the right valve, and no lateral teeth. Length less than one-third of an inch." Conrad, $18+3$.

The strong concentric laminæ stand nearly perpendicular to the surface, are somewhat inequidistant and between them are numerous fine, close set striæ; main and subordinate striæ at times of nearly equal strength; within smooth, pallial margin and muscle impressions often, though not always, distinet; shell fragile.

Length, $12 \mathrm{~mm}$; height, $9.8 \mathrm{~mm}$; diameter, $3.1 \mathrm{~mm}$.

Occurrence.-Choptank Fonutaton. Governor Run, 2 miles sonth of Governor Run, Flag Pond, Turner, Jones Wharf, Greensboro.

Collections.-Maryland Geological Survey, Johns Hopkins University.

Aligena æquata rar. NUDA Dall.

Plate LXXXIX, Fig. 1.

Aligend cquete vur. mude Dall, 1900, Trans. Wagner Free Inst. Sci., vol. iii, pt. v, p. 1175-6, (informe).

"Occasional specimens [of A. aquata] are found in which the laminæe fail to develop, forming the variety nuda, Dall." Dall, 1900. 
Occurrence.-Calveqt Formation. Plum Point.

Collection.-Maryland Geological Survey.

Aligena pustulosa Dall.

Plate LXXXIX, Figs. 5a, 5b.

Aligene pustulosa Dall, 1898, Trans. Wagner Free Inst. Sci., vol. iii, pt. iv, p. 928, 1). xxxiii, tigs. $18,22$.

Aligena pustulosa Dall, 1900, Trans. Wagner Free Inst. Sci., vol, iii, pt. v, p. 1176.

Description.- "Shell small, thin, subtrigonal, moderately inflated, subequilateral, with small, pointed, inconspicuous beaks; valves with a well-marked carina extending downward and forward to the anterior angle of the basal margin, in front of which keel the surface is slightly impressed; surface sculptured with feeble incremental lines, along which are irregularly distributed, small, pointed, pustular elevations; beaks anteriorly twisted with a minute obscure tooth below them on the cardinal margin; ligamentary sulcus long and well marked; scars and pallial line much as in Diplodonta; margin entire, inner surface faintly radially striated. Alt. 6, lat. 5.2, diam. 4 mm." Dall, 1900.

Occurrence.-Calvert Formation. "Calvert Cliffs" (= Plun Point?).

Collection.-U. S. National Museum.

\section{Superfamily LUCINACEA. Family DIPLODONTIDÆ. Genus DIPLODONTA Brown. \\ Diplodonta acchints Conrad. \\ Plate LXXXIX, Figs. 6a, 6b.}

Lucina acclinis Conrad, 1832, Fossil Shells of the Tertiary, p. 21, pl. vi, tig. 2.

Mysin americana Conrad, 1838, Fossils of the Medial Tertiary, 1. 30, pl. xvi, fig. 2. Diplodontre arelinis Conrad, 185s, Proe. Acad. Nat. Sci. Phila., vol. ix, p. 166.

Nysin acclinis Conrad, 1863 , Proc. Acad. Nat. Sci. Phila., vol. xiv, p. 57\%.

Nysiu arelinis Meek, 1864, Miocene Check List, Smith. Misc. Coll. (183), p. 8.

Diplodontu acclinis Dall, 1898, Trans. Wagner Free Inst. Sci,, vol, iii, pt, iv, pl. xxviii, figs. 2, 13 .

Diplodonta acelinis Dall, 1900, Trans. Wagner Free Inst. Sci., vol. iii, pt. v, p. 11 s6.

Description.—. Suborbicular, or lentiform, a Little oblique, with strong lines of growth; hinge with 2 diverging teeth in each valve; posterior 
tooth of the right valve bifid; anterior muscular impression not profoundly elongated." Conrad, 1832.

Length, $33 \mathrm{~mm}$.; height, $31 \mathrm{~mm}$.; diameter, $8 \mathrm{~mm}$.

Occurrence.-St. Mary's Formation. St. Mary's River. Choptank Foratation. Governor Run, 2 miles sonth of Governor Run, Flag Pond, Jones Wharf, Turner, Dover Bridge, Greensboro. Calvert Foniation. Church Hill, Reed's, Fairhaven.

Collections.-Maryland Geological Survey, Johns Hopkins University.

\title{
Diplodonta shilomensis Dall.
}

Plate IXXXIX. Figs. 7, 8.

Hysia paritis Conrad, 1866, Amer. Jour. Conch., vol. ii, p. 71, pl. iv, fig. 1.

Not Mysia parilis Conrad, $1860,1865$.

Mysia paritis Whitfield, 1895, Mon. xxir, U. S. Geol. Survey, p. 61, pl. ix, figs. 9-13.

Diplodonta shilohensis Dall, 1900, Trans. Wagner Free Inst. Sci., vol. iii, pt. v, p. 1184 .

Description.- "Equilateral, nearly circular, ventricose, thin and fragile; basal and anterior margin regularly rounded." Conrad, 1866.

Beaks not prominent, situated just slightly nnterior to the middle of the valve; shell very globular; curvature of margin very nearly circular; curvature of surface almost spherical.

Length, $10 \mathrm{~mm}$; height, $9 \mathrm{~mm}$; diameter, $4 \mathrm{~mm}$.

Occurrence.-Сhорталк Forication. Jones Wharf, Dover Bridge.

Collections.-Maryland Geological Survey, Johns Hopkins University.

\author{
Section SPHÆRELLA Conrad. \\ Diplodonta subtexa (Conrad). \\ Plate LXXXIX, Figs. 9, 10.
}

Spherella subvexa Conrad, 183s, Fossils of the Medial Tertiary, p. 18, pl. x, fig. 2.

Erycina subconiexa d'Orbigny, 1852, Prod. Pal. Strat., vol. iii, p. 115.

Spherella subvexa Conrad, 1863, Proc. Acad. Nat. Sci. Phila., vol. xiv, p. 57 .

Sphrevella subvexa Meek, 1864, Miocene Check List, Smith. Mise. Coll. (183), p. 8.

Diplodonta (Sphcerella) subvexa Dall, 1900, Trans. Wagner Free Inst. Sci., vol, iii, pt. v, p. 1186.

Description.- "Shell globose, thin and fragile; disk with fine lines of growth; umbo very prominent, slightly oblique, nearly central; lunule undefined; margins rounded." Conrad, 1838. 
Shell nearly hemispherical. length slightly greater than height; cardinal teeth small, projecting, in right valve three, in left valve two, ligament area narrow; muscular impressions sometimes indistinct; external surface nearly smooth. Rare and very difficult to obtain entire.

Length, $34 \mathrm{~mm}$.; height, $32 \mathrm{~mm}$; diameter, $14 \mathrm{~mm}$.

Occurrence.-Сhoptank Fonmation. Goternor Pun, Flag Pond, Jones Wharf. Calvert Formatios. Phum Point.

Collections.-Maryland Geological Survey, Johns Hopkins University.

\section{Family LUCINIDÆ.}

Genus PHACOIDES Blainville.

Subgenus PSEUDOMILTHA Fischer.

Pilacoides (Pseudoniltifa) forejaxi (Conrad).

Plate XC, Figs. 1, 2.

Lueinu Foremani Conrad, 1841, Proc. Acad. Nat. Sci. Phila., vol. i, 1. 29.

Luciue Fomemani Conrad, 1842, Jour. Acad. Nat. Sci. Phila., vol. viii, 1st sel., p. 184.

Lmine Foremuni Conrad, 1845, Fossils of the Medial Tertiary, p. 71, pl, xI, fig. 4.

Lueina Foremuni Conrad, 1st3, Proc. Acad. Nat. Sci. Phila, rol, xiv, p. 5\%;.

Lucinu foremuni Meek, 1864, Miocene Check List, Smith. Misc. Coll. (183), p. 8.

Phacoides (Psendomiltha) Foremani Dall, 1903, Trans. Wagner Free lnst. Sci., vol. iii, pt. vi, p. $13 \%$.

Description.- - Orbicular, rentricose, moderately thick: surface with irregular shallow groores, and rather distant prominent strix, with intermediate, fine, concentric lines; posterior margin subtruncated obliquely outwards; beaks prominent, not central; hinge edentulous. Length, $1 \frac{1}{2}$ inch." Conrad, $18+1$.

It may be distinguished from $P$. anodonta by being smaller and much more convex; as found in Maryland, the interior, prismatic portion of the shell is often badly decayed. while the exterior portion is msually well preserved; it is at times quite thick.

Jength, 35.5 mm.; height, $3.1 \mathrm{~mm}$.; diameter, $8.5 \mathrm{~mm}$.

Occurrence.-Cinoptank Fonmation. Governor Rum. Calvent Formation. Phum Point.

Collections.-Maryland Geological Survey, Jolms Hopkins Unirersity. 


\section{Phacoides (Pseudomiltha) anodonta (Say). Plate XC, Figs. 3, 4.}

Lucine unodonte Say, 18:4, Jour. Acad. Nat. Sci. Phila., vol. iv, p. 146, pl. x, fig. 9. Lucinc unodontu Conrad, 1840, Fossils of the Medial Tertiary, p. 39, pl. xx, fig. 4.

Lucine anodontu Tuomey and Holmes, 1856 , Pleiocene Fossils of South Carolina, P. 55, pl. xviii, fig. 2.

Lusine Americana Conrad, 1863, Proc. Acad. Nat. Sci. Phila., vol. xir, p. 5rr.

Lucinu Americun Meek, 1864, Miocene Check List, Smith. Misc. Coll. (183), p. 8.

Phacoides (Pseudomiltha) anodonta Dall, 1903, Trans. Wagner Free Inst. Sci., vol, iii, pt. vi, p. $13 \pi 8$.

Description.- "Orbicular, slightly transverse, compressed; teeth obsolete.

"Shell with elevated wrinkles; orbicular, a little transverse, with a very slight impressed longitudinal line on the anterior margin; anterior and posterior ends equally curred; apices not prominent beyond the general curve of the shell, with a very short, deep emargination behind them; teeth obsolete; both the cardinal and lateral ones are generally altogether wanting; lunule short, cordate, profound. . . .

"The impressed line on the anterior part of the shell is hardly visible in many specimens, and is sometimes only a very slight undulation, not observable but on close inspection. . . ." Say, 1824.

Distinguished readily by its being flat, toothless and usually thick, with distinct pallial line and muscle impressions.

Length of very large specimen, $69 \mathrm{~mm}$; height, $6.5 \mathrm{~mm}$.; diameter, $10 \mathrm{~mm}$.

Occurrence.-St. Mary's Formation. Cove Point, St. Mary's River. Choptank Foriation. Governor Run, 2 miles south of Governor Run, Flag Pond, Jones Wharf, Turner, Dover Bridge, Peach Blossom Creek. Calvert Formation. Chesapeake Beach, 3 miles south of Chesapeake Beach, Plum Point.

Collections.-Maryland Geological Survey, Johns Hopkins University.

Subgenus HERE Gabb.

Section CAVILUCINA Fischer.

Phacoides (Here) trisuldatus (Comrad).

Plate XC, Figs. \%, 8, 9.

Lucina trisuleate Conrad, 1S41, Amer. Jour. Sci., vol. xli, p. 346.

Lncine trisuleata Conrad, 1845, Fossils of the Medial Tertiary, p. rl, pl. xl, tig. 12. 22 
Lucim trisulcata Tuomey and Holmes, 1856, Pleiocene Fossils of Sonth Carolina, p. 6*2, pl. xviii, figs. 18,19 .

Lucinu trisuleuta Conrad, 1863, Proc. Acad. Nat. Sci. Phila., vol. xiv, 1. 57т.

Lucint trisulenta Meek, 1864, Miocene Check List, Smith. Misc. Coll. (183), p. 8.

Lurinu trisulcata Whittield, 1s94, Mon. xxiv, U. S. Geol. Survey, r. 64, pl. x, figs. $1-4$.

Lucina crenulate Whitfield, 1894, Mon. xxiv, U. S. Gcol. Survey, p. 63, pl. x, figs. 7-15 (not of Conrad).

Phacoides (Cavilucina) trisulcutus Dall, 1903, Trans. Wagner Free Inst. Sci., vol. iii, pt. vi, p. 1369.

Description.- "Obovate, convex; with concentric lines, and two or three distinct concentric furrows; lunule profound. Differs from $L$. alveata of the lower tertiary in being less ventricose, and in the much more profoundly impressed lunule; the cardinal teeth are also very different." Conrad, 1841.

Shell inequilateral, being somewhat produced anteriorly; beak, consequently not medial; moderately convex or more usually rather flattened, especially anteriorly; a small, flattened groove or depressed band extending from the beak backward along the posterior submargin; the two or three concentric iurrows very distinct or, again, very indistinct or entirely wanting; or at times only one furrow present, being either distinct or indistinct; margin crenulated.

Specimens that are rather elevated and ornamented by fine concentric ridges only approach rather closely to the form of $P$. crenulatum, but may be distinguished from it by having a heavier hinge area and a more profound lunule and by being somewhat produced anteriorly and not quite so elevated. Whitfield has figured as $P$. crenulatum the smoother form of $P$. trisulcatum from New Jersey.

Length of large specimen, $8 \mathrm{~mm}$; height, $8.5 \mathrm{~mm}$; diameter, $2 \mathrm{~mm}$.

Occurrence-Choptank Formation. Greensboro, Cordova. CaLvert Formation. Chesapeake Beach, 3 miles south of Chesapeake Beach, Plum Point, Truman's Wharf, 3 miles west of Centerville, Church Hill.

Collections.-Maryland Geological Survey, Johns Hopkins University, U. S. National Mruseum. 
Subgenus LUCINOMA Dall.

\section{Phacoides (Lucinoma) contractus (Say).}

Plate XC, Figs. 5, 6.

Lucinu contractu Say, 18:24, Jour. Acad. Nat. Sei. Phila., rol. iv, 1st ser., P. 145 , pl, $x$, fig. 8 .

Lucinc contrute Conrad, 1840 , Fossils of the Medial Tertiary, p. 40, pl. xx, tig. 5. Lucina subplamata Conrad, 1841, Proc. Acad. Nat. Sci. Phila., vol. i, p. 29 (young). Lucinu subplerutu Conrad, 184:, Jour. Acal. Yat. Sci. Phila., vol. viii, 1st ser., p. 184.

Lucine contructe Tuomey and Holmes, 1856, Pleiocene Fossils of South Carolina, 1. 54 , pl. xviii, fig. 1.

Lueina contrerte Conrad, 1863, Proc. Acad. Nat. Sei. Phila., vol. xis, p. 57\%.

Lurinu subplanutu Conrad, 1863, Proc. Acad. Nat. Sei. Phila,, vol. xiv, p. 5r

Lnciur contructa Meek, 1864, Miocene Check List, Smith. Misc. Coll. (183), p. \&.

Lucim, subplum Meek, 1864, Niocene Check List, Smith. Misc. Coll. (183), p. 8.

Phucoilles (Lucinome) contruetus Dall, 1903, Traus. Wagner Free Inst. Sci., vol. iii, pt. ri, p. 1380.

Description.- "Shell convex, suborbicular, with numerous, concentric, regular, equidistant, elevated, membranaceous striæ, and intermediate smaller transverse lines: umbones not very prominent: apices proximate, nearly central: anterior hinge margin rectilinear, to an obtuse angle near the middle of the anterior margin: anterior submargin with a very slightly impressed line: posterior margin rounded: cardinal teeth one in the left valve, and two in the right, the posterior one of which is subbifid at tip: latcral teeth none: within obsoletely striated towards the margin: posterior muscular impression perfectly rectilinear, elongated, and oblique." Say, $182 \pm$.

Easily distinguished by the elevated, concentric lamellæ. An impressed line extends from the beaks to the posterior margin; shell thin and rather fragile.

Len.rth, $42 \mathrm{~mm}$; height, $39 \mathrm{~mm}$; diameter, $5.9 \mathrm{~mm}$.

Occurrence.-St. Mary's Formation. St. Mary's River. Choptaxk Foruration. Governor Run, 2 miles south of Governor Run, Flag Pond, Pawpaw Point, Jones Wharf, Greensboro, Cordova. Calvert ForuaTion. Fairhaven, Lyon's Creek, 3 miles south of Chesapeake Beach, Plum Point, Jewell.

Collections.-Maryland Geological Survey, Johns Hopkins University. 


\section{Subgenus PARVILUCINA Dall. \\ Phacoides (Parvilucina) crenulatus (Conrad).}

Plate XC, Figs. 10, 11, 12.

Lurime cremelte Conrad, 1840, Fossils of the Medial Tertiary, p. 39, pl. xx, tig. 2.

Leciue leus H. C. Lea, 1845, Trans. Amer. Philos. Soc., vol, ix, P. 240, pl. xxxiv, tig. 19.

Lincine cremlatu Tuomey and Holmes, 1856 , Pleiocene Fossils of Sonth Carolina, 1. 60, pl. xviii, figs. 14,15 .

Luciue cremutate Emmons, 1858, Rept. N. C. Geol. Snrvey, p. 291, tig. 217 (fig. poor).

Lucine crenulata Conrad, 1863, Proc. Acad. Nat. Sei. Phila,, vol. xiv, p. 57\%.

Lucinu remulatu Heek, 1864, Miocene Check List, Smith. Misc. Coll. (183), 1) \&.

Not Lucimu cremelate Whitield, 1s94, Mon. xxiv, U. S. Geol. Survey, p. 63, pl, x, figs. $7-15$.

Phecoides (Pamilurime cremelutus Dall, 1903, Trans. Wagner Free Inst. Sci., vol. iii, pt. vi, p. 1383, pl. lii, tig. 12.

Description.-... Shell lenticular, with numerous concentric laminæ; a submarginal fold on the posterior side; posterior extremity truncated; cardinal line straight, oblique; beaks central; cardinal and lateral teeth distinct; margin minutely crenulated." Conrad, 1840.

Shell orbicular in ontline and highly convex or elevated; usually rather thin; hinge area not heavy or broad; anterior side not produced. For distinction from $P$. trisulcatus see remarks under that speeies.

Whitfield has figured as L. crenulata some of the smoother and more rounded forms of $P$. trisulcatus.

Length, $6.2 \mathrm{~mm}$; height, $6 \mathrm{~mm}$; diameter, $1.8 \mathrm{~mm}$.

Occurrence.-ST. MarY's Formation. Cove Point, Langley's Bhuft, St. Mary's River. Choptank Fonutaton. Governor Rum, 2 miles south of Grovernor Run, Flag Pond, Jones Wharf, Turner, Pawpaw Point, Trappe Landing, Peach Blossom Creek, Dover Bridge, Greensboro, Cordova. Cilvert Formatios. Chesapeake Beach, 3 miles south of Che a jeake Beach, Plum Point, Reed's.

Collections.-Maryland Geological Survey. Tohns Hopkins University.

\section{Phacoides (Parvilucina) prunus Dall.}

Plate XC, Fig. 13.

Phacoides (Pervilucine premes Dall, 1903, Trans. Wagner Free Inst. Sci., vol, iii, It. vi, p. 1384, pl. lii, fig. 8 .

Description.-"Shell resembling $P$. crenulutus but flatter, more inequilateral, with thicker and more regular concentric ribs, no radial 
sculpture, the inner margins more finely crenulate or even smooth, lunule shorter and wider, and the posterior dorsal area narrower and more ventrical than in $P$. crenulatus. Alt., 6.5, lon., \%.0, diam., $4.0 \mathrm{~mm}$.

"The beaks are much more prominent and more recurved over the small globular lunule, the ribs are wider than their interspaces, and the radial structure is seen only when the shell is decoricated." Dall, 1903.

Occurrence.-St. Mary's Formation. St. Mary's River. Calvert Formation. Plum Point.

Collection.-U. S. National Museum.

Subgenus LUCINISCA Dall.

Phacoides (Lucinisca) cribrarius (Say).

Lucina cribraria Say, 1824, Jour. Acad. Nat. Sci. Phila., vol. iv, 1st ser., p. 147, pl. xiii, fig. 1.

Lucina cribruria Conrad, 1842, Proc. Nat. Inst., Bull. ii, p. 187.

Phacoides (Lucinisca) cribrurius Dall, 1903, Trans. Wagner Free Inst. Sci., vol, iii, pt. vi, p. 1372.

Description.-The type specimen of this species has been generally thought to come from St. Mary's County, Maryland. The anthor knows of no authentic specimen from Maryland in any collection, notwithstanding the extensive collections which have been made by the Maryland Geological Survey. He is of the opinion that Say's type really came from Virginia.

Occurrence.-St. MarY's Formation. St. Mary's River. (Conrad).

Genus DIVARICELLA von Martens.

Divaricella quadrisulcata (d'Orbigny).

Plate XCV, Fig. 8.

Tellina divaricate Dillwyn, 1817, Cat. Rec. Sh., i, p. 102 (ex parte), and of many other authors.

Lucina quadrisuleata d'Orbigny, 1846, Voy. Am. Mér., p. 584.

Divaricella quadrisuleuta Dall, 1903, Trans. Wagner Free Inst. Sci., vol. iii, pt. vi, p. 1389, pl. li, fig. 1 .

Description.-This species has been listed from Maryland but the author knows of no anthentic specimen in any collection and has failed to find it himself. Say's specimen of this species is also believed to have come from Virginia. 
Dr. Dall says of it: "The chief characteristies of this species are the long. narrow, somewhat sinuous lunule, the straight hinge-line with the shell margin at its ends subangulate, the fine crenulation of the margin of the valves, and the absence dorsally of the rude denticulation due to the surface sculpture from which $D$. dentata. Wood derives its name.

Occurrence.-Calvert Forulaton. "Prince George Comnty and elsewhere." (Dall).

Collection.-U. S. National Museum.

\section{Superfamily CHAMACEA. \\ Family CHAMIDÆ. \\ Genus CHAMA Linné. \\ CHAMA CONGREGATA C'OMrad. \\ Plate XCI. Figs. 1, 2, 3.}

Chermu congregutu Conrad, 1s33, Amer. Jour. Sci., vol, xxiii, p. 341.

Cherme congregatu Conrad, 1835, Fossils of the Medial Tertiary, p. 32, pl. xvii, fig. 2.

Chama congregata Tuomey and Holmes, 1855, Pleiocene Fossils of sonth Carolina, 1. 23, pl. vii, figs. $7-10$.

Chame congregate Conrad, 1868, Proc. Acad. Nat. Sei. Phila., vol. xiv, p. 5ib.

Chame congregute Meek, 186t, Miocene Check List, smith. Mise. Coll. (183), 1. S.

Chema fongreguta Whittield, 1894, llon. xxiv, U. S. Geol. Survey, p. 65, pl. ix, figs. $14-18$.

Chama congregutu Dall, 1903, Trans. Wagner Free Inst. Sci., vol. iii, pt. ri, p. 1400.

Description._" Shell sessile, dextral; superior valve a little convex, with numerous, ereet, elevated, arched seales; beaks occasionally rostrated; apex subspiral; scales on the inferior valve broarler and more elevated; inner margin crenulated." Conrad, 1833.

The shape of the lower valve is more or less modified by the surface to which it is attached; within, anterior and posterior muscle impressions and pallial line distinct. The curving of the beak to the right as well as the smaller size and much less massive character of the shell, readily separate it from $C$. corticosa.

Length, $32 \mathrm{~mm}$.; height, $33 \mathrm{~mm}$; diameter, $12 \mathrm{~mm}$.

Occurrence.-CALVERT Formation. Chureh Hill, abundant, and rare at the following localities: 3 miles west of Centerville. 3 miles south of Chesapeake Beach, Plum Point, Truman's Tharf.

Collections.-Maryland Geological Survey, Johns Hopkins University. 


\section{Superfamily CARDITACEA. \\ Family CARDITID Æ. \\ Genus CARDITA (Bruguière) Lamarck. \\ Section CARDITAMERA Conrad. \\ Cardita protracta (Conrad). \\ Plate XCI, Figs. 4, 5, 6 .}

Carditamera protracta Conrad, 18+3, Proc. Acad. Nat. Sci. Phila., vol. i, p. 305.

Carditamera protracta Courad, 1845, Fossils of the Medial Tertiary, p. 65, pl. xxxrii, fig. 2.

Cardite protracte d'Orbigny, 1852, Prod. Pal. strat, vol. iii, p. 114, No. 2134.

Carditamera protracta Conrad, 1863, Proc. Acad. Nat. Sci. Pbila., vol. xiv, p. 579.

Carditamera aculeata Conrad, 1863, Proc. Acad. Nat. Sci. Phila., pp. 578, 585.

Carditamera protracta Meek, 1864, Miocene Check List, Smith. Misc. Coll. (183), p. ‡. Carditamera aculeata Meek, 1864, Miocene Check List, Smitl. Misc. Coll. (183), p. 7. Carditamera recta Conrad, 1869, Amer. Jour. Concl., vol. ir, p. 279, pl. xx, fig. 2.

Carditamera aculenta Whitfield, 1894 , Mon. xxir, U. S. Geol. Survey, p. 58, pl. ix, figs. $7,8$.

Cardita (Carditumera) recta Dall, 1903, Trans. Wagner Free Inst. Sci., vol. iii, pt. vi, p. 1413.

Cardita (Carditamera) protructe Dall, 1903, Trans. Wagner Free Inst. Sci., vol. iii, pt. vi, p. 1414.

Description._- "Trapezoidal, elongated, compressed, widely contracted from beak to base; dorsal and basal margins nearly parallel; ribs about 15, the middle ones triangular and crenated; posterior ribs rounded and having distant, arched, squamose, coarse striæ; summit of the beaks scarcely prominent above the linge line." Conrad, 1843.

There seems to be no sufficient ground for separating the Maryland Miocene Carditameras. They show a gradual decrease in the number of ribs from forms with about nineteen to twenty-one in the earlier deposits, as at Church Hill, to forms with fifteen to seventeen in later deposits, as at Jones Wharf. Occasionally a specimen is rather prolonged, or slightly thicker, or is not so widely contracted from beak to base, but these variations all seem too slight to be considered of even varietal value. The $C$. aculeata is merely a young form. C. recta is not more prolonged than many a Governor Run specimen of C. protracta. C. carinata, first described from Newbern, N. C., is listed by Conrad from Dover Bridge-the Choptank near Easton. If his identification were not wrong, then it is probable that $C$. carinata should be united with $C$. protracta and take precedence of the latter name. 
C. arata was described by Conrad from Newbern, N. C. and from Dover Bridge (near Easton), Md. The figure and description fit the stouter, shorter southern Miocene species with its fewer ribs and short hinge-line, but does not fit the forms found by the writer at Dover Bridge or any other Maryland Miocene horizon. He believes that the Maryland forms referred by Conrad in 1832 to $C$. arata were different from the common Carolina form, $C$. arata, of which $C$. carinata is a synonym merely, and belonged to the then undifferentiated species $C$. protracta. which occurs abundantly at Dover Bridge and was first described by Conrad in 1843. The latter is proportionally longer, thinner, with more numerous ribs and has more nearly linear and parallel dorsal and ventral margins.

Length, $39 \mathrm{~mm}$.; height, $18 \mathrm{~mm}$.; diameter, $7 \mathrm{~mm}$.

Occurrence.-Сногталк Fonunton. Governor Rum, 2 miles south of Governor Run, Flag Pond, Jones Wharf, Dover Bridge, Greensboro. Calvert Formatiox. Fairhaven, Plum Point, Magruder's Ferry, Church Hill, 3 miles west of Centerville.

Collections.-Maryland Geological Survey, Johns Hopkins University.

Genus VENERICARDIA Lamarck.

Teneric.irdia granulata Say.

Plate XCI, Figs. \%, s, 9, 10.

Venericerdia grameletr Say, 18:24, Jour. Acad. Nat. Sci. Phila., vol. iv, 1st ser., p. 142, pl, xii, fig. 1 .

Curdita gramelutu Conrad, 1835, Amer. Jour. Sci., vol. xxviii, p. 110.

Curditu gremelete Conrad, 1838 , Fossils of the Medial Tertiary, 1. 12, pl. vii, tig. 1.

Carditu granulutu Tuomey and Holmes, 1856, Pleiocene Fossils of South Carolina, 1. 66, pl, xix, figs. 7,8 .

Cerditu tridentatu Emmons, 1858, Rept. N. C. Geol. Survey, p. 302, fig. 2364; not of Say, $18: 6$,

Actimobolus (Cardita) gratenlute Conrad, 1863, Proc. Acad. Nat. Sci. Phila., vol, xiv, 1. 578.

Venericurdi" (Cardiomatrs) gramlata Meek, 1S64, Miocene Check List, Smith. Mise. Coll. (183), p. ז.

Fenericurdia borealis ear. granuluta Dall, 1859, Bull, xxxvii, U. S. Nat. MI s., p. 46.

Curdite grametute Whitfield, 1894, Mon. xxiv, U. S. Geol. Survey, p. 5i, pl. ix, figs. $1-4$.

Tenericurdia (Cyclocardin) granulatu Dall, 1903, Trans. Wagner Free Inst. Sci., rol. iii, pt. vi, p. 1431. 
Description.—"Suborbicular, with about twenty-five convex ribs, and wrinkled across; inner margin crenate.

"Beaks nearly central, a little prominent, curved backward: ribs granulated on the umbones, and transversely wrinkled near the base, convex: apices somewhat prominent beyond the general curve of the shell: inner margin and edge crenate: cardinal teeth two.

"Length from the apex to the base four-fiftls of an incli, breadth nearly the same.

"Rather proportionally longer than the decussata and more oblique." Say, $182 \pm$.

None of the Maryland specimens have as many as twenty-five ribs. Those from the Calvert formation have eighteen to twenty-one, those from the Choptank formation sixteen to eighteen, and those from St. Mary's formation, serenteen to nineteen. They approach V. granulata, therefore, in number of ribs.

From Calvert formation, length, $16 \mathrm{~mm}$; height, $17 \mathrm{~mm}$.; diameter, $6.5 \mathrm{~mm}$. From St. Mary's River, length $26 \mathrm{~mm}$; height, $28 \mathrm{~mm}$; diameter, $9.5 \mathrm{~mm}$.

Occurrence.-St. Marr's Formation. Cove Point, St. Mary's River, Choptank Formation. Governor Rum, 2 miles south of Governor Run, Flag Pond, Jones Wharf, Cuckold Creek. Calvert Formation. Chesapeake Beach, 3 miles south of Chesapeake Beach. Plum Point, Truman's Wharf.

Collections.-Maryland Geological Survey, Johns Hopkins University, U. S. National Museum, Academy of Natural Sciences of Philadelphia.

\section{VENERICARDiA CASTRANA n. sp.}

Plate XCI, Figs. 11, 12.

Description.-Outline suborbicular, beaks acute, prominent, curved forward; shell depressed or flattened; ribs twenty-four to twenty-seven, finely granulated and slightly conver near the beak and without granulations but crossed by fine concentric wrinkles or growth lines over the rest of the shell; the impressed lines between the ribs distinct near the beak but almost obsolete on the outer part of the shell; ribs almost perfectly flat on outer part of shell; teeth strong; muscle impressions and pallial line distinct; inner margin crenated. 
The much greater flatness of the shell, the absence of granulations on the ribs exeept very near the umbo, the very slight eonvexity of the ribs themselves giving the surface an almost smooth appearance, as well as the number of the ribs, readily distinguish this speeies from any of the Maryland specimens of Venericardia granulata.

Length, $20 \mathrm{~mm}$; height, $21 \mathrm{~mm}$.; diameter, $4.5 \mathrm{~mm}$.

Occurrence.-Calvert Formation. Church Hill, Reed's.

Collections.-Maryland Geologieal Survey, Johns Iopkins University.

\section{Superfamily ASTARTACEA. \\ Family CRASSATELLITID Æ. \\ Genus CRASSATELLITES Kruger. \\ Crassatelitites arelindos (Conrad). \\ Plate XCII, Figs. 1, 2.}

Corassetella melina Conrad, 1882, Fossil Shells of the Tertiary, p. 23, 11. ix, fị. 2.

Corssatella melina Conrad, 1838, Fossils of the Medial Tertiary, p. 22, pl. xii, tig. :2. Crassutella metina Conrad, 1863 , Proc. Acad. Nat. Sci. Phila., vol. xiv, p. 578.

Crassatella melina Meek, 1864, Miocene Check List, Smith. Mise. Coll. (188), 1. 7.

Crassatella melina T'hitfield, 1894, Mon. xxiv, U. S. Geol. Survey, p. 60, pl. viii, figs. 11-15.

Crossutellites (Scambula) melinus Dall, 1903, Trans. Wagner Free Inst. Sci., vol. iii, pt. vi, p. 1473.

Description.—"Ovate, thick, not eompressed; anterior margin obtusely rounded; posterior margin oblique and angular; dorsal margin nearly straight; coneentric lines coarse; umbonial slope subangular and scarcely eurved; beaks with concentrie grooves; inner margin entire." Conrad, 1832.

This species, as found in Maryland, is more properly described as subovate, convex-depressed, and rather thin exeept in old specimens, which are somewhat thicker and more convex. It is somewhat more produced posteriorly and henee is proportionally narrower along the obliquely truncated posterior margin than is represented in Conrad's figure. The dorsal slope has regular, well marked, angular, concentric undulations near the beak that become obsolete during later stages of growth; posterior and dorsal slopes separated by a distinctly angular line; posterior slope somewhat flattened; posterior dorsal margin but 
slightly concave; hinge area rather narrow, not massive; muscular impressions and pallial margin very distinet.

Iength, $88 \mathrm{~mm}$.; height, 4 r mm.; diameter, $15 \mathrm{~mm}$.

Occurrence.-Chlvert Formation. Fairhaven, Lyon's Creek, Chesapeake Beach, 3 miles south of Chesapeake Beach. Plum Point, Church Hill.

Collections.-Maryland Geological Survey, Jolns Hopkins University, U. S. National Mruseum.

\section{Crassatelitites marylandious (Conrad).}

Plate XCIII, Figs. 1, 2, 3.

Crassatella Marylandica Conrad, 1832, Fossil Shells of the Tertiary, p. 22, pl. viii, tig. 1.

Crassatella Marylandicu Conrad, 1538, Fossils of the Medial Tertiary, P. 21, pl. xii, tig: 1.

Crassatella Marylandica Conrad, 1868 , Proc. Acad. Nat. Sci. Phila., vol. xiv, p. 5 \%s. Crassatella marylandica Meek, 1864, Miocene Check List, Smith. Misc. Coll. (183), p. $\%$.

Crecsatellites (Scambula) murylandicus Dall, 1903, Trans. Wagner Free Inst. Sci., vol. iii, pt. vi, p. 1473 (in part).

Description._- Ovate oblong, thick and ponderous; posterior side narrowed and produced, with the extremity angular or obtusely rounded; umbonial slope subangular; inner margin entire." Conrad, 1832.

Shell convex; umbo elevated and prominent; regular concentric undulations on umbonal slope very slightly developed or obsolescent; surface marked by somewhat irregular growth lines; posterior basal margin often slightly emarginate; posterior and dorsal slopes meet in an angular line or ridge; posterior slope crossed by a slightly obtuse ridge extending from the beak to the upper end of the obliquely truncated posterior margin; posterior dorsal margin deeply concave, anterior one straight; hinge area broad; teeth robust; muscular impressions deep; pallial line distinct.

The young are convex, thick and massive also, with prominent beaks and but slightly produced posterior extremity, giving the shells a triangular outline. The regular, concentric undulations on the umbonal slope are small and not profound and are confined to the portion of the surface in the immediate vicinity of the umbo. 
This species is likely to be confused in the adult stage with $C$. turgidulus, with which it is doubtless closely related. For distinctions between the two, see remarks under C. turgidulus.

Length, $84 \mathrm{~mm}$; height, $57 \mathrm{~mm}$; diameter, $17 \mathrm{~mm}$.

Occurrence.-Сhoptank Formation. Govemor Run (upper bed only), Flag Pond (upper bed only), Turner, Peach Blossom Creck, Dover Bridge.

Collections.-Maryland Geological Survey, Johns Topkins University, U. S. National Museum, Philadelphia Academy of Natural Sciences.

\section{Crassatellites turgidulus (Conrad).}

Plate XCTI, Figs. 3, 4, 5.

Cressutella turyidula Conrad, 1843, Proc. Acad. Nat. Sci. Phila., vol. i, p. 307.

Cressutella turgidula Conrad, 1845, Fossils of the Medial Tertiary, p. 69, pl. xxxix, fig. $\because$.

Cirssatelle turgidula Conrad, 1S63, Proc. Acad. Nat. Sci. Phila., vol. xix, p. 5is.

Crassutellu trogitula Meek, 1864, Miocene Check List, Smith. Mise. Coll. (1s3), p. 7

Crassatellites (Scambula) marylundicus Dall, 1903, Trans. Wagner Free Inst. Sci., vol. iii, pt. vi, p. 1473 (in part).

Description.-_ Oblong-ovate, slightly ventricose; surface with coarse lines of growth, and concentric undulations obsolete except on the umbones, where they are strongly marked and wide; beaks submedial; umbones flattened; anterior dorsal margin straiglit; posterior extremity truncated and nearly direct, more oblique in young shells; basal margin swelling a little anteriorly, posteriorly straight to the extremity which is obliquely angulated." Conrad, 1843.

Shell thick, convex, and not strongly produced posteriorly; umbo not prominently elevated; posterior dorsal margin slichtly concave or nearly straight; hinge area broad; teeth robust; muscular impressions deep; pallial line distinct.

The young are long-ovate in outline, thin and flat; surface with rery prominent, regular, angular, concentric undulations on the umbonal slope and extending over a large portion of the entire surface of the shell; posterior dorsal margin straight or convex.

This species is likely to be confused with $C$. marylandicus, but may be separated in the adult stage by having a less prominent, broader, and more flattened umbo and a more profoundly and widely undulated um- 
bonal slope, by being less produced posteriorly and by having a much less concave posterior dorsal margin. The young of the two species are quite distinct and need never be confused with each other.

This species seems to be confined to the lower of the two fossiliferous beds at Governor Run, Jones Wharf and that horizon elsewhere, and characterizes it just as the $C$. marylandicus seems confined to, and is characteristic of, the upper of these fossiliferous beds.

Length, $87 \mathrm{~mm}$.: height, $55 \mathrm{~mm}$.; diameter, $17 \mathrm{~mm}$.

Occurrence.-Choptaxk Fonmation. Governor Rum (lower bed), 2 miles south of Governor Rum (lower bed), Flag Pond (lower bed). Jones Wharf, Pawpaw Point, Cuckold Creek, Greensboro.

Collections.-Maryland Geological Survey, Johns Hopkins University, U. S. National Museum, Philadelphia Academy of Natural Sciences.

\section{Crassatellites undulatus (Say).}

Crassutella meluelute Sas, 18:24, Jour. Acad. Nat. Sci. Phila., vol. iv, 1st ser., p. 142, pl. xii, tị. 2 .

Coessutelle unduluta Conrad, 1832, Fossil shells of the Tertiary, p. 23, p]. ix.

Crassatellites (Scambula) undulutus ver. cyclopterus Dall, 1903, Trans. Wagner Free Inst. Sci., vol. iii, pt. vi, p. $147 t$.

Description.-This species is believed to be another of the Tirginia forms given to Say by Finch and erroneously described as coming from Maryland. No authentic Maryland specimens of this species are known by the writer.

Occurrence._-"Maryland" (Dall).

Subgenus CRASSINELLA Guppy.

Crassatellites (Crassinella) duplinianes Dall.

Plate XCIT, Fig. 12.

Crossatellites (Crussimellø) dupliniumus Dall, 190:, Trans. Wagner Free Inst. Sci., vol. iii, pt. ri, p. 14is, pl. 1, tigs. 5, 6.

Description._- Shell small, subtriangular, solid, with markedly accute beaks, which incline backward; anterior slope convexly arcuate, long; posterior slope nearly a straight or slightly concave line, shorter; lunule and escutcheon extending the whole length of their respective slopes, long and narrow, the latter more excavated than the former and wider; 
both are smooth; base arcuate; disk sculptured with rather close-set, regular, subequal, flattish, concentric ridges with narrower interspaces; these are sometimes feebly elevated, but preserve their general close-set, regular character; hinge well developed, the posterior cardinal in the left valve often conspicuous. Height, 3.2 , breadth, 3.2, diameter, 1.7 nm.

"This species is especially characterized by the closeness, regularity, and smoothness of its concentric ridges and the long and narrow lumule and escutcheon." Dall, 1903.

I.ength, $3.4 \mathrm{~mm}$. ; height, $3.24 \mathrm{~mm}$. ; diameter, $0.75 \mathrm{~mm}$.

Occurrence.-Сhoptank Formation. Greensboro. Calvert Formaтton. Plum Point (U. S. Nat. Mus.).

Collections.-Maryland Geological Survey, U. S. National Museum.

Crassatellites (Crassinella) galvestonensis (Harris).

Plate XCIV, Figs. 13, 14.

Eviphyle galeestonensis Harris, 1895, Bull. Amer. Pal., vol. i, p. 90, pl. i, figs. 2, a, b. Cressatellites (Crossinelle) gulestonensis Dall, 1903, Trans. Wagner Free Inst. Sci., vol. iii, pt. vi, p. 1478, pl. xlix, fig. 14.

Description.- " Form as indicated by the figures; hinge as in E. Tunulata; exterior smooth, slightly undulating concentrically near the beaks; beaks, as in many species of Astarte and Crassatella, slightly flattened at the very apex but very gibbous just below." Harris, 1895 .

Length, $7.2 \mathrm{~mm}$. ; height, $6.65 \mathrm{~mm}$.

Oecurrence.-St. Mary's Forantion. St. Mary's River.

Collection.-Maryland Geological Survey.

\section{Family ASTARTIDÆ. \\ Genus ASTARTE Sowerby. \\ Astarte vicisa Say. \\ Plate XCIII, Figs. 10, 11.}

Isturte virine Say, 1824, Jour. Acad. Nat. Sci. Phila., vol. iv, 1st ser., p. 151, pl. ix, tig. 6.

Astarte virim Conrad, 1840, Fossils of the Medial Tertiary, p. 41.

Astarte exultata Conrad, 1841, Proc. Acad. Nat. Sci. Phila., vol. i, p. 29.

Asterte exaltate Conrad, 1842, Jour. Acad. Nat. Sci. Phila., vol. viii, 1st ser., p. 185.

Asturte exaltata Conrad, 1845 , Fossils of the Nedial Tertiary, 1. 66, pl. xxxiii, fig. 6. 
Astarte vicina Con rad, 1863, Proc. Acad. Nat. Sci. Phila., vol. xir, 1. 578. Astarte exaltata Conrad, 1868, Proc. Acad. Nat. Sci. Phila., vol. xiv, p. 578. Astarte vicina Meek, 1864, Miocene Check List, Smith. Misc. Coll. (183), p. т. Astarte cxaltata Nleek, 1864, Miocene Check List, Smith. Nisc. Coll. (183), p. 7. dstarte vicina Dall, 1903, Traus. Wagner Free Inst. Sci., vol. iii, pt. vi, P. 1459. Astarte exultute Dall, 1903, Trans. Wagner Free Inst. Sci., vol. iii, pt. vi, p. 14s!.

Description._"Trigonal, with a distant, somewhat regular, impressed line; lunule much excavated; apices acute.

"Apices prominent: lunule dilated, deeply excavated, subcordate, separated from the disk, particularly near the beaks, by a subacute angle: beaks prominent, approximate, acute, curved backwards: ligament margin concave: umbones convex." Say, 182t.

Margin posterior to the beak nearly straight, anterior to the beak profoundly concave. The sulcations of the umbo gradually change into obscure undulations over the rest of the surface. Margin crenulated or smooth. The anterior, basal, and posterior margins form a nearly symmetrical curve. Umbonal region thick; cardinal teeth strong.

Length, $18 \mathrm{~mm}$; height, $18 \mathrm{~mm}$.: diameter, $5 \mathrm{~mm}$.

Occurrence.-St. Mary's Formation. St. Mary's River. Calvert Forintion. 3 miles south of Chesapeake Beach, Plum Point.

Collections.-Maryland Geological Survey, Johns Hopkins University.

\section{Astarte thonasil Conrad.}

Plate XCIV, Figs. 1, :.

Astarte Thomasii Conrad, 1855, Proc. Acad. Nat. Sci. Phila., vol. vii, p. 267. Astarte Thomasii Conrad, 186:, Proc. Acad. Nat. Sci. Phila., vol. xiv, 1) 578. Astarte Thomasii Meek, I864, Miocene Check List, Smith. Misc. Coll. (183), p. $\tilde{\imath}$. Astarte Thomasii Conrad, 1866, Amer. Jour. Conch., vol, ii, p. 72 , pl. ir, fig. 16. Astarte Thomasii Whitfield, 1894, Mon. xxiv, U. S. Geol. Survey, p. 55, pl. viii, fịss. $3-\tau$.

Asturte Coheni Dall, 1903, Trans. Wagner Free Inst. Sci., vol. iii, pt. ri, p. 14s!) (in part).

Description._" Triangular, not ventricose, inequilateral; ribs concentric, robust, recurved; concentric lines more or less marked, minute; toward the posterior end the ribs suddenly become obsolete; extremity truncated, nearly direct, or sloping inwards; inner margin crenulated; lumnle large, ovate, acute, deeply excavated." Conrad, 1855. 
Shell rather thick and solid, especially in the umbonal region: cardinal teeth well developed; margin crenulated or smooth.

Length, 22 mm.; height, $19 \mathrm{~mm}$.: diameter, $6 \mathrm{~mm}$.

Occurrence. - Calnert Formation. Plum Point, Lyon's Creek (rare).

Collections.-Maryland Geological Survey, Johns Hopkins University, Academy of Natural Sciences of Philadelphia.

Astarte calvertensis n. sp.

Plate XCIV, Figs. 3, 4.

Asturte culvertensis (Glenn) Dall, 1908, Trans. Wagner Free Inst. Sci., vol. iii, pt. vi, pp. 1492,1494 (listed)..

Description.- T'riangular; shell nearly flat, with about forty-five regular, nearly equal concentric lines; apex moderately prominent, right angled or obtuse; anterior side shorter than posterior; lunule not deeply excarated; anterior basal margin a well rounded curve, posterior basal margin straight or slightly emarginate; posterior extremity above the line of the base and sharply rounded; posterior side straight; ligament areas impressed: teeth moderately prominent; basal margin crenate or smooth.

This species differs from A. bella, A. concentrica and A. compsonema (all three synonymous?) to which it seems most closely related by being thinner, much flatter. less equilateral, more emarginate posteriorly and with less prominent and less projecting beaks.

Length, $25 \mathrm{~mm}$; height, $20 \mathrm{~mm}$; dianneter, $4.5 \mathrm{~mm}$.

Occurrence.-Caldert Fornation. Plum Point.

Collection.-Maryland Geological Survey.

\section{Astarte symmetrica Conrad.}

Astarte symmetrica Conrad, 1834, Jour. Acad. Nat. Sci. Phila,, vol, vii, 1st ser. p. 134 .

Astarte symmetrica Dall, 1903, Trans. Wagner Free Inst. Sci., vol. iii, pt. vi, p. 1488.

Description.-This species has not been found by the author among Maryland materials.

Occurrence.-St. Mary's Formation (?). St. Mary's River.

Collection.-U. S. National Museum. 


\title{
Astarte cuneiformis Conrad.
}

\author{
Plate XCIII, Figs. 4, 5, 6.
}

Astarte cuneiformis Conrad, 1840, Fossils of the Medial Tertiary, 1. 4:, pl. xx, fig. 9. Astarte varians Conrad, 1841, Proc. Acad. Nat. Sci. Phila., vol, i, p. 29.

Astarte variares Conrad, 1842, Jour. Acad. Nat. Sci. Phila., vol. viii, 1st ser., p. 184. Asturte variuns Conrad, 1845, Fossils of the Medial Tertiary, p. 67, pl. xxxvii, fig. 7 . Astarte runeiformis Conrad, 1863, Proc. Acad. Nat. Sci. Phila., vol. xiv, p. 578.

Astarte euneiformis Meek, 1864, Miocene Check List, Smith. Misc. Coll. (183), p. 7. Astarte variuns Meek, 1864, Miocene Check List, Smith. Misc. Coll. (183), p. 7.

Astarte meneiformis Whitfield, 1894, Mon. xxiv, U. S. Geol. Survey, p. 52, pl. viii, fig. 10 only.

Astarte (Ashtarotha) cuneiformis Dall, 1903, Trans. Waguer Free Inst. Sci., vol. iii, pt. vi, p. 1494.

Description.—" Shell trigonal, much compressed; umbo flat, with distant, shallow undulations, and acute little prominent ridges; apex very acute; lunule very profound, with a sharply carinated margin; posterior side produced, cuneiform, acutely rounded at the extremity; cardinal teeth long and rather slender; margin crenulated." Conrad, 1840.

This shell is quite variable. The undulations near the beak may be either coarse or quite fine and may extend over a good portion of the surface, or they may be almost obsolete. The posterior side may be much produced and acutely rounded, giving the shell a distinctly cuneiform shape; or it may be only very slightly, if at all, produced, when the shell becomes more compact and triangular in outline. 'This shortening may continue until some specimens approach A. vicina in outline. The inner margin may be smooth. The base may be regularly arched or may be emarginate posteriorly.

Length, $33 \mathrm{~mm}$.; height, $23 \mathrm{~mm}$; diameter, $6 \mathrm{~mm}$.

Occurrence.-CaLVert Foriration. Chesapeake Beach, 3 miles south of Chesapeake Beach, Plum Point, 'Truman's Wharf, Lyon's Creek.

Collections.-Maryland Geological Survey, Johns Hopkins University, U. S. National Mruseum, Academy of Natural Sciences of Philadelphia, Cornell University.

Astarte castrana n. sp.

Plate XCIII, Figs. 7, 8, 9.

Asterte (Ashturotha) obrutu Dall, 1903, Trans. Wagner Free Inst. Sci., vol. iii, pt. vi, p. 1490 (in part).

Description.-Shell triangular, nearly equilateral, with rounded base; beak acute, turned slightly forward; shell flat or depressed; outer surface 
with small, shallow concentric grooves near the beak, slightly undulated over the rest of the shell by obscure and irregular growth lines, or in some specimens almost perfectly smooth over this outer part; teeth robust; ligament areas impressed; pallial line distinct; margin smooth or crenulated.

This species is doubtless the ancestor of Astarte thisphila from which it may be readily separated by its much smoother surface, much flatter form and thinner shell, as well as by its lacking the flattening or depression near the umbo so characteristic of thisphila. It has a less prominent beak, is flatter, less symmetrically rounded, thinner and much less smooth on the surface than Astarte obruta. It is found only at a lower horizon than either of the other two species mentioned above.

Length, $25 \mathrm{~mm}$; height, $21 \mathrm{~mm}$; diameter, $4 \mathrm{~mm}$.

Occurrence.-Calvert Formatios. Plum Point, Church Hill, Reed's. Collections.-Maryland Geological Survey, Johns Hopkins University.

\section{Astarte obruta Conrad.}

$$
\text { Plate XCIV, Figs. 5, } 6 .
$$

Astarte obrute Conrad, 1834, Jour. Acad. Nat. Sci. Phila, vol. vii, 1st ser., p. 150. Asturte obruta Conrad, 1840 , Fossils of the Medial Tertiary, p. 48, pl. xxi, fig. 2.

Asterte obmute Conrad, 1863 , Proc. Acad. Nat. Sei. Phila., vol. xiv, 1). 578.

Asturte obretu Meek, 1st5t, Miocene Check List, Smith. Misc. Coll. (183), p. 7.

Asturte (Ashturotha) obrutu Dall, 1903, Trans. Wagner Free Inst. Sci., rol. iii, pt. vi, 1). 1490 (in part).

Description._" Shell triangular, convex, smooth, with a few obsolete undulations; beaks prominent, sulcated, margin crenulated. . . .

"Allied to A. undulata Say, but is more convex and not profoundly undulated; the umbo is not flattened." Conrad, 183 .

Shell nearly equilateral, moderately tinick; the sulcations on the beak usually not prominent and extending but a very short distance from the tip of the beak; the rest of the gently convex surface smooth except for a few broad, almost obsolete, undulations; surface occasionally crossed from beak to base by exceedingly faint, slightly impressed, radial lines; beak projecting, acute, with its rery tip curved somewhat forward.

The gently rounded outline, and moderately convex, almost smooth surface serve to distinguish this species from any other. It is characteristic of the horizon of the upper fossiliferous bed at Governor Run, having been found, so far, at no other horizon. 
Length, $27.5 \mathrm{~mm}$; height, $23.5 \mathrm{~mm}$.; diameter, $6 \mathrm{~mm}$.

Occurrence--Снортахк Fonмatiox. Gorernor Run (upper bed), 2 miles south of Governor Run (upper bed), Flag Pond (upper bed), Turner, Dover Bridge, Peach Blossom Creek, Trappe Landing, Sand Hill.

Collections.-Maryland Geological Survey, Johns Hopkins University, Academy of Natural Sciences of Philadelphia.

\section{Astarte thisphila n, sp. \\ Plate XCIV, Figs. 7, 8, 9.}

Asturte uredulatu Conrad, 1542, Proe. Nat. Inst., Bull. ii, p. $1 \mathrm{s5}$ (listed only); not of sas, 1s:2t.

Asturte melulatu Conrad, 156\%, Proc. Acad. Nat. Sci. Phila., vol. xix, 1) 139 (listed only).

Asturte obrutu wu. Harris, 1s93, Amer. Jour. Sci., ser. iii, rol. xlv, pp. 26,27 (listed only).

Asturte (Ashtarotha) undulata Dall, 1903, Trans. Wagner Free Inst. Sci, vol. iii, pt. vi, p. 1491 (in part).

Description.-Shell triangular; moderately thick, convex, but depressed or flattened near the beak; angular undulations on the beak prominent, becoming broader farther from the beak and extending well toward, or in some cases entirely to, the basal margin; tip of beak curved forward, producing a convex curve or shoulder on the dorsal margin just posterior to the apex; anterior margin regularly rounded; basal margin rounded anteriorly, straight or slightly emarginate posteriorly; posterior extremity above the line of the base and obtusely rounded; interior smooth except in quite young specimens, when it is sometimes slightly undulated; teeth strong.

This species is quite common at the horizon of yellowish sands so well exposed at Jones Wharf and has often been listed as A. undulata or as A. obruta, or A. obrutu var. It differs from $A$. undulata Say by being usually less convex, by having coarser, broader undulations and a greater flattening near the beak, by being much less variable in its proportion of length to height-the height being less than the length while in undulata it is often greater-and by having a much more curved basal margin than the undulata.

It differs from the $A$. obruta by having a less symmetrically curved surface and outline, by being strongly undulated and by the characteristic 
convex curve or shoulder just posterior to the tip of the beak. Stratigraphically its occurrence is distinct from that of obruta since it has only been found in beds lower in the Miocene series than those containing the obruta.

It differs from A. distans by being thicker and more convex, by having more numerous and more angular undulations, by having a beak that is less acute and prominent and more abruptly and strongly curved forward. The 1. distans cammot, moreover, be considered as the young of this species.

The few specimens obtained from Plum Point agree with the typical ones from Jones Wharf except that they have a somewhat less strongly undulated surface. They were found at Plum Point only in a very sandy stratum close to tide level. From this sand-loving characteristic it receives its name.

Length, $30 \mathrm{~mm}$. ; height, $26 \mathrm{~mm}$; diameter, $7 \mathrm{~mm}$.

Occurrence.-Choptank Fonmation. Governor Run (lower bed), 2 miles south of Governor Run (lower bed), Flag Pond (lower bed), Jones Wharf, Pawpaw Point, Cuckold Creek, Cordova, Greensboro. CaLvert Formation. Plum Point.

Collections.-Maryland Geological Survey, Johns Hopkins University, U. S. National Museum, Philadelphia Academy of Natural Sciences.

\section{Astarte. perplana Conrad.}

Plate XCIV, Figs. 10, 11.

Asturte perpluna Conlad, 1840 , Fossils of the Medial Tertiary, p. 43, pl. xxi, fig. 3. Astarte plenututu [sic.] Conrad, 184\%, Proe, Nat. Inst., Bull. ii, p. 187, (listed only). Astarte perplomu Conrad, 1s63, Proc. Acad. Nat. Sci. Phila., rol. xir, p. 5 s.

Asturte plemulute Conrad, 1863 , 'roc. Acad. Nat. Sci. Phila, vol. xir, p. 575.

Asturte perplunu Meek, 1864, Miocene Check List, Smith. Misc. Coll. (183), p. $\tau$.

Astarte plumulutu Meek, 186it, Miocene Check List, Smith. Mise. Coll. (183), p. 7.

Asturte (Ashtarotha) perplune Dall, 1903, Trans. Wagner Free Inst. Sci., rol. ii, pt. vi, p. 1493.

Description._."Shell triangular, inequilateral, much compressed; disks coarsely wrinkled and obscurely undulated; posterior side subcuneiform; extremity rounded; beaks prominent, acute, with angular grooves; lunule long, elliptical; inner margin crenulated." Conrad, 1840.

The strength of the undulations is somewhat variable; shell rather thick and solid; inner margin crenulated or smootl.

Length, $36 \mathrm{~mm}$. ; height, $29 \mathrm{~mm}$. ; diameter, $6 \mathrm{~mm}$. 
Occurrence.-St. Mary's Formation. St. Mary's River.

Collections.-Maryland Geological Survey, Johns Hopkins University, U. S. National Museum.

\section{Astarte Parma Dall:}

Plate XCIV, Fig. 15.

Asturte (Ashtarotha) purma Dall, 1903, Trans. Wagner Free Inst. Sci., vol. iii, pt. vi, p. 1493, pl. 1vii, fig. 22.

Description._. "Shell very flatly compressed, inequilateral, rostrate, the beaks at the anterior third low, acutely pointed, slightly recurved; lunule narrow, deeper than wide; escutcheon, narrow, deep, as long as the posterior slope, which is almost straight; sculpture of the beaks with about five small, fine ribs, close together, followed by three or four very distant, much wider ripples, obsolete towards the ends and ventral margin, with a few irregularly spaced linear concentric sulci beyond; posterior dorsal profile slightly arcuate, basal margin slightly emarginate behind; anterior end rounded, posterior end pointed; inner ventral margins crenate; hinge-plate broad and flat with two long, narrow cardinals in each valve. Height, 25.0, length, 28.5, diameter, $7.0 \mathrm{~mm}$.

"This curious form differs from perplana by its more compressed, flatter, and more acutely pointed valves, and by its umbonal sculpture." Dall 1903.

Occurrence.-Calvert Formation. Skipton, Plum Point. Collection.-U. S. National Museum.

\section{Order ANOMALODESMACEA. Superfamily ANATINACEA. \\ Family PANDORIDÆ. \\ Genus PANDORA Hwass.}

Subgenus CLIDIOPHORA Carpenter.

Pandora (Clidiophora) crassidens Comrad.

Plate XCV, Figs. 1, 2.

Pendora rrussidens Comrad, 1S38, Fossils of the Nedial Tertiary, p. 2, pl. i, fig. 2. Pandora cretsidens Conrad, 1863, Proc. Acad. Nat. Sci. Phila., vol. xiv, p. 5 \%2.

Pandora crussidens Meek, 1864, Miocene Clieck List, Smith. Misc. Coll. (183), p. 12. 
D)escription.- "Shell perlaceous, concentrically wrinkled; the large valve extending much beyond the posterior base of the lesser; anterior side very short, margin widely subtruncate; posterior obtusely rounded inferiorly, terminating above in a very short and obtuse rostrum; dorsal stibmargin of the larger valve with two approximate carinæ; lesser valve with only one distinet carina placed very near the margin; anterior cardinal tooth of the larger valve very long, thick, and slightly oblique, the posterior one very near the dorsal line, sulcate or fosset shaped; the middle one short and linear; in the flat valve, two oblique, very thick and prominent teetls, anterior to which is a shallow groove, bounded anteriorly by a rudizentary linear tooth; muscular impressions impressed; pallial impressen punctate." Conrad, 1838.

Length, $20 \mathrm{~mm}$.; height, $15 \mathrm{~mm}$.; diameter, $4 \mathrm{~mm}$.

Occurrence.--St. Marr's Formation. Cove Point, St. Mary's River. Collection.--Maryland Geolngical Survey.

Subgenus KENNERLEYIA Carpenter.

Paxdora (Kennerteyia) lata Dall.

Plate XCV, Fig. $\therefore$.

Pendore (Kennerleyir) Zutu Dall, 1908, Trans. Wagner Free Inst. Sci., vol. iii, pt, ri, 1. $15: 0$, , ll. 1vii, fig. $1 \mathrm{~s}$.

Description.- "Shell small, left valve very convex, patulous below behind, with a rather broad escutcheon bounded by a strong carina; anterior area short, posterior area very narrow; rostrum very short and blunt, slightly recurved; surface concentrically striated; hinge-teeth short and small; lumule rery decp, compressed, so as to appear linear; right valve slightly concare, concentrically striated, with traces of the usual impressed radiating lines. Length 19.0, height 10.5, diameter $3.5 \mathrm{~mm}$.

This species is shorter and thicker than $P$. arenosa and much less acute. Its exact provenance is not known, as it was received from the old National Institute, but the specimens have the livid purple color characteristic of many of the St. Mary's fossils, and it is possible it was collected in that region." Dall, 1903.

Occurrence.-St. Ifari's Formatiox (?). St. Mary's County (?).

Collection.-U. S. Xational Inseum. (Xational Institute Collection). 


\title{
Family PERIPLOMATID Æ.
}

Genus PERIPLOMA Schumacher.

Periploma peralta Comrad.

Plate XCV, Fig. 3.

Periplome alta Conrad, 1863, Proc. Acad. Nat. Sci. Phila., vol. xiv, pp. 572, 585.

Not Ametina alta C. B. Adams, 1852.

Periploma alta Meek, 1864, Miocene Check List, Smitb. Misc. Coll. (183), p. 11.

Periplome alta Conrad, 1866, Amer. Jour. Conch., vol. ii, p. r0, pl. iv, fig. 10.

Periplome peralta Conrad, 186\%, Amer. Jour. Conch., vol. iii, p. 1s.

Periplome perulta Dall, 1903, Trans. Wagner Free Inst. Sci., vol. iii, pt. vi, p. 1529.

Description - "Suborbicular, subequilateral, anterior side subrostrated, end truncated, direct; basal margin profoundly rounded medially and posteriorly; anteriorly obliquely truncated or very slightly emarginate.

"A much larger species than P. (Anatina) papyracea, Say, but closely allied." Conrad, 1863.

Shell large, depressed, thin; valves subcircular; external surface minutely pustulose.

Length, $63 \mathrm{~mm}$; height (of fragment), $55 \mathrm{~mm}$.

Occurrence.-St, Marr's Formation. Cove Point.

Collection.-Maryland Geological Survey.

\author{
Family THRACIIDÆ. \\ Genus THRACIA Leach. \\ Tinracia conradi Couthouy. \\ Plate XCV, Fig. 4.
}

Thracia declivis Conrad, 1831, Amer. Nar. Conch., p. 44, pl. ix, fig. 2; not of Pennant, 177\%, Brit. Zool., vol. iv, p. 15; nor of Donovan (fide Couthouy) Conrad's synonymy excluded.

Thracia Conradi Couthouy, 1839, Bost. Jour. Nat. Ilist., vol. ii, p. 153, pl. iv, fig. 怘

Thracia Conradi Gould, 1841, Invert Mass., p. 50.

Thracia Conradi DeKay, 1843, Nat. Hist. N. Y., Zoology vol. i, p. 237, pl. xxviii, fig. :284.

Threcie Comradi Gould (Binney's), 1870, Invert. Mass., 1', 69, fig. 384.

Thruciu Conradi Dall, 1889, Bull. xxxrii, U. S. Nat. Ius., p. 64, pl. Ixix, fig. 9.

Thracin Conradi Dall, 1903, Trans. Wagner Free Inst. Sci., vol. iii, pt. vi, p. 1524.

Description.- "Shell transversely ovate, rentricose, very light, brittle and thin, rather faintly diaphanous by reason of its want of thickness, 
subequilateral, slightly gaping at both extremities, inequivalve, the right valve being the more convex, its whole margin projecting considerably beyond that of the left; beaks protuberant, large and cordiform, inclining a little backwards, the summit of the right one excavated or emarginate to receive the opposing one; incremental striæ" numerous and distinct, occasionally forming feeble concentric ridges; the anterior portion of the shell is regularly rounded and its superior margins very thin; the posterior extremity is rather narrower and somewhat truncated, with an obtuse carination extending obliquely from the beaks to the angle of the basal and posterior margins; between this carination and the superior and posterior margins the shell is slightly compressed. The basal margin is sinuous, curving outwardly in its central portion, correspondent to the most convex part of the shell. Ligament externally very prominent, and prolonged in a thin membrane the whole length of the corselet which is strongly marked and extends from the beaks to the extremity; the internal portion of the ligament is attached to a strong, thick nymphal callosity, projecting obliquely along the cardinal edge in each valve, wider toward the beaks and having its surface but slightly hollowed. Hinge destitute of a cardinal ossiculum. External color a pale, ashy-white surface covered with a thin, light, cinereous epidermis, strongly adherent and forming numerous irregular, minute corrugations at the extremities, especially on the posterior one, but not shagreened as in T. corbuloides. Interior color a chalky white, not glassy, but somewhat inclining to nacre near the cardinal edge. Muscular impressions tolerably large, remote, the anterior narrow, elongated, contracted and tapering to a point towards the hinge margin; the posterior subtriangular or pyriform; pallial impression very superficial, like the others, with a profound, subangular excavation posteriorly.

"Length two and eighteen-twentieths, height two and four-twentieths, diameter one and six-twentieths inches." Couthouy, 1839.

The fossil shell seems usually to be larger than Couthouy's living ones. Although often abundant, all specimens the writer has seen have been more or less broken and flattened. Because of this distortion their exact shape is difficult to determine and the writer prefers to retain until more perfect material is obtainable the name conradi. When such 
material is secured it will very probably show the fossil to be at least varietally different from the living species. In this event Dr. Dall's proposed varietal name harrisi will apply.

Length, $75 \mathrm{~mm}$; height, $60 \mathrm{~mm}$.; diameter, about $14 \mathrm{~mm}$.

Occurrence.-Calvert Formation. Fairhaven, Lyon's Creek, Plum Point, Chesapeake Beach.

Collection.-Maryland Geological Survey.

\author{
Family PHOLADOMYACIDÆ. \\ Genus MARGARITARIA Conrad. \\ Margaritaria abrupta (Conrad). \\ Plate XCV, Figs. 5, 6.
}

Pholudomya abrupta Conrad, 1832, Fossil Shells of the Tertiary, 1. 26, pl. xii.

Pholadomya abrupta Conrad, 1838, Fossils of the Medial Tertiary, p. 3, pl. i, fig. 4.

Pholadomya abrupta Tuomey and Holmes, 1856, Pleiocene Fossils of South Carolina, p. 101, pl. xxiv, fig. 2.

Pholadomya ubrupta Emmons, 1858, Rept. N. Car. Geol. Survey, p. 300, fig. 231.

Pholadomya (Margaritaria) abrupta Conrad, 1863, Proc. Acad. Nat. Sci. Phila., vol. xiv, p. $5 \% 2$.

Margaritaria abrupta Meek, 1864, Miocene Check List, Smith. Misc. Coll. (183), p. 12.

Margavitaria abrupta Dall, 1903, Trans. Wagner Free Inst. Sci., vol. iii, pt. vi, p. 1532.

Description.- "Oblong oval, much compressed, with from three to five subacute distant ribs or ridges diverging from the apex; one side rather thick and strong, rounded at the extremity; the opposite side extremely thin, and reflected, with a truncated margin; muscular and pallial impressions distinct." Conrad, 1832.

The shell is pearly and fragile and is readily identified by the radial ridges crossing the dorsal portion of the shell from the beak to the base. The Survey possesses only some fragments.

Occurrence.-St. Mary's Formation. Cove Point, St. Mary's River. Calvert Formation. White's Landing.

Collection.-Maryland Geological Survey. 


\title{
Order PRIONODESMACEA.
}

\author{
Superfamily MYTIL/ÆEA.
}

Family MYTILID E.

Genus MYTILUS Bolten.

\section{Mytilus conradinus d'Orbigny.}

Plate XCVI, Figs. 1a, 1 b.

Wytilus incressatus Conrad, 1841, Amer. Jour. Sci., vol. xli, p. 347; not of Deshayes 1830.

Mytilus incrasutus Conrad, 1845, Fossils of the Medial Tertiary, p. 7t, pl. xlii, tig. 4.

Mytilus Conralinus d'Orbigny, 1552, Prod. Pal. Strat., vol. iii, 1. 12\%.

Nytilus incrasstus Tuomey and Holmes, 1856, Pleiocene Fossils of South Carolina, 1. 32, pl. xiv, figs. 1, 2.

Mytiluroncha ineressete ('on rad, 1862, Proc. Acad. Nat. Sci. Phila., rol. xiv, 1) 291.

Mytiloconcha incressate Conrad, 1863, Proc. Acad. Nat. Sci. Phila., vol. xiv, p. 5r9.

Nytiloconcha incrussate Meek, 1s64, Miocene Check List, Smith. Misc. Coll. (1\$3), p. $\tau$.

Mytilus Conmelimes Dall, 1s98, Trans. Wagner Free Inst. Sci, vol. iii, pt. iv, p. isi.

Description.- "Thick, much inflated; anterior margin slightly incurved near the middle; basal margin not obtusely rounded; hinge thick, with slightly prominent robust teeth." Conrad, $18+1$.

A remarkably large and almost perfect left valve from Plum Point shows the following characters: Shell highly convex, apically acute, laterally curved and posteriorly rounded in outline; external surface marked by distinct, inequidistant, concentric undulations with finer subordinate ones between; dorsal margin a convex curve; ventral margin a gently concave curve; beak heavy, solid; posterior portion of shell moderately thin; interior dull pearly; hinge or tooth ridge long, narrow, curved and prolonged on the beak as a marginal groove; beak not medially grooved.

The apical portions are msnally the only part preserved. When young and badly worn, as is ofteu the case, jt becomes rery difficult to separate $M$. conradinus from $M$. incurvus.

Length, $180 \mathrm{~mm}$.; width, $78 \mathrm{~mm}$.; diameter, $3 \pm \mathrm{mm}$.

Occurrence.-Choptank Formation. Governor Rum, Flag Pond, Jones Wharf, Peach Blossom Creek, Dover Bridge, Greensboro. CaLvert Formation. Chesapeake Beach, 3 miles south of Chesapeake Beach, Plum Point, Church Hill. 
Collections.-Maryland Geological Surrey, Johns Hopkins University, U. S. National Mruseum, Philadelphia Academy of Natural Sciences.

Subgenus MYTILOCONCHA Conrad.

Mrtilus (Mrtiloconcha) incurvus Conrad.

Plate XCVI, Figs. 2, 3, 4.

Myoconcha incurva Conrad, 1839, Fossils of the Medial Tertiary, p. 3 of cover of No. 1; p. 52, pl. xxriii, fig. 1, 1840.

Mytilus incurvus Conrad, 1854, Proc. Acad. Nat. Sci. Phila., rol. viii, p. 29.

Wytilus (Nyoconchu) incurves Conrad, 1861, Fossils of the Medial Tertiary, No. 4 , p. 88 .

Mytiloconche incurva Conrad, 1862, Proc. Acad. Nat. Sci. Phila., vol. xir, p. 291.

Nytiloconcha incurve Conrad, 1863, Proc. Acad. Nat. Sci. Phila,, rol. xiv, p. 579.

Mytituconche incurva Meek, 1864, Miocene Check List, Smith. Misc. Coll. (183), p. 7.

Mytiloconcha incressatu Whittield, 1894, Mon. xxiv, U. S. Geol. Survey, p. 38, pl. T, figs. 10, 11; not of Conrad.

Mytilus (Mytiloconcha) iurmens Dall, 1598, Trans. Wagner Free Inst. Sci., vol. iii, pt. iv, p. 789.

Description. - "Shell incurved, thick, narrowed towards the apex; posterior side with a submarginal furrow; hinge with a narrow straight groore for the cartilage, and a broad furrow on the posterior side." Conrad, 1839 .

This shell is heavier, more sharply curved, has a longer and more massive cardinal area and more nearly equidistant dorsal and ventral margins than $M$. conradinus; teeth strong, two in left and one in right ralve, becoming obsolete in old age. As the cardinal area increases in length with growth the teeth are prolonged apically as ridges with a furrow on each side; area otherwise flat except for a marginal ligament groove extending along the posterior side of the area to the apex.

Length of imperfect valve, $120 \mathrm{~mm}$.; width, about $35 \mathrm{~mm}$.

Occurrence.-Choptank Foramatox. Greensboro, Cordova, neal Skipton, Dover Bridge (Dall). Calrert Formation. Church Hill, Truman's Wharf. Also at an unknown horizon in Calvert County (Conrad).

Collections.-Maryland Geological Survey. U. S. National Musemm, Philadelphia Academy of Natural Sciences. 
Genus LITHOPHAGA Bolten.

Lithophaga subalveata Conrad.

Plate XCVII, Fig. 1.

Lithophaga subulecute Conrad, 1866, Amer. Jour. Conch., vol. ii, p. 7:, pl. iv, tig. 4. Lithophuga subulecute Whittield, 1894, Mon. xxiv, U. S. Geol. Survey, p. 40, [pl. v, fig. 9.

Description.—" Oblong, very thin and fragile, ventricose, posterior side produced, a slight wide furrow marks the umbonal slope, on and behind which are concentric grooves and lines; basal line slightly emarginate or contracted." Conrad, 1866.

A single broken valve shows a produced posterior side with a slight, wide, flat furrow on the umbonal slope crossed by concentric grooves with posterior end narrow and somewhat bluntly rounded. From a comparison with Conrad's broken and poorly patched type in the Academy of Natural Sciences, the two shells seem to be the same.

Occurrence.-Calvert Formation. 3 miles west of Centerville.

Collections.-Maryland Geological Survey, Philadelphia Academy of Natural Sciences.

\section{LithopHAGA IONENSIS n. sp.}

Plate XCVIT, Figs. 2, 3.

Description.- Shell very thin and fragile, anterior end rounded, posterior region broadened, posterior end rounded; external surface either smooth or concentrically wrinkled across the umbonal slope; ventral margin slightly convex; dorsal margin straight to the posterior end of the hinge line, then rounded and declining; within, a slight submarginal dorsal thickening or ridge just beneath, and extending the length of, the hinge and minutely grooved for the ligament; beak not prominent; no sulci.

Some specimens are less inflated and posteriorly broadened and more cylindrical with nearly straight ventral margin, and dorsal margin at posterior end of hinge line more angular than the type. These differences, however, do not seem to be of enough value to warrant varietal distinction. Specimens are found in the shells of Melina, Ostrea and Pecten, at times riddling these shells by their boring. 
Length, $13 \mathrm{~mm}$.; width, $6 \mathrm{~mm}$.; diameter, $2 \mathrm{~mm}$.

Occurrence.-ChOp'TaNK Formation. Jones Wharf, Dover Bridge, Greensboro, Cordova.

Collections.-Maryland Geological Survey, Johns Hopkins University.

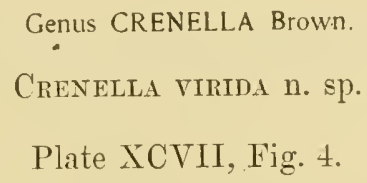

Description.-Shell very small, thin, delicate, of pearly gray luster, elongated ovate in shape, elevated; beak projecting and sharply rounded; margins gracefully curved; radial scupture of fine, close-set, narrow, rounded, raised lines, their number increasing by dichotomy and by intercalation between older lines.

As compared with $C$. dupliniana this species is more elongated, less elevated, less robust, has coarser sulcations and these sulcations are more branching than in C. dupliniana.

Length, $1.65 \mathrm{~mm}$.; width, $1.25 \mathrm{~mm}$.

Occurrence.-Сhoptank Formation. Greensboro.

Collection.-Maryland Geological Survey.

\section{Crenella gubernatoria n. $\mathrm{sp}$. \\ Plate XCVII, Fig. 5.}

Description.-Shell small, stout, rounded ovate, anteriorly broadened; shell depressed; beak rounded and projecting very slightly; radial sculpture prominent and coarse, ridges flattened and with narrow interspaces, some being dichotomous, other added ribs are intercalated between previously existing ones.

This is a less elevated, more rounded, more coarsely sculptured and stouter species than C. virida.

Length, $1.72 \mathrm{~mm}$.; width, $1.5 \mathrm{~mm}$.

Occurrence.-Сhoptank Formation. Governor Run.

Collection.-Maryland Geological Survey. 
Genus MODIOLUS Lamarck.

Modiolus ducatelis Conrad.

Plate XCVII, Figs. 6, \%.

Modiola Duatellii Conrad, $1 \times 40$, Fossils of the Medial Tertiary, p. 53, pl. xxviii, fig. :.

Peinu Duentellii Conrad, 1863 , Proc. Acad. Nat. Sci. Phila., rol. xir, p. 5\%9.

Volsella Ducutelli Heek, 1s64, Miocene Check List, Smith. Misc. Coll. (183), 1) 7.

Modiolus Ducetelii Dall, 1898, Traus. Wagner Free Inst. Sci., vol. iij, 1)t. iv, v. 793.

Description.- "Shell profoundly elongated, ventricose, ralves contracted obliquely from the apex to the middle of the basal margin; lines of growth coarse and prominent; extremity of hinge line salient and rounded; posterior extremity regularly rounded; anterior extremity rather prominent and pointed." Conrad, $18 \pm 0$.

This shell is rarely found entire. But its identification should give no difficulty, especially if the beak is present.

Length, $133 \mathrm{~mm}$; width, $55 \mathrm{~mm}$. ; djameter, $21 \mathrm{~mm}$.

Occurrence.-St. Mary's Forifation. Cove Point. Choptank Formation. Governor Run, a miles south of Governor Run, Jones Wharf, Tumer, Dover Bridge, Cordova. Canvert Formation. Chesapeake Beach, 3 miles south of Chesapeake Beach, Plum Point, Reed's.

Collections.-Maryland Geological Survey, Johns Hopkins University, Maryland Academy of Science, U. S. National Minseum.

\section{Section GREGARIELLA Monterosato.}

Modiolus virginicus (Conrad).

Plate XCVII, Figs. Sa, Sb.

Wolioluitu virginien Conrad, 186\%, Amer. Jour. Conch., vol ii, p. 26\%, pl. xxii, fig. 3.

Modiolarib virginicu Dall, 1s9s, Trans. Wagner Free Inst. Sci, vol. ii, pt. iv, p. s06.

Description.- "Oblong, subarcuate, rentricose anterior side without radiating lines; umbonal slope raised, rounded with close, crenulated, radiating lines, extending to the posterior margin and disposed to bifurcate towards the base; beaks nearly terminal." Comrad, $186 \%$.

In front of the smooth area extending from the umbonal area to the ventral margin there is a small area near the beak with radiating crenulated lines; edge of valve finely headed; dorsal margin not angular but curved. 
There seem to be no good generic grounds for separating $M$. virginicus, $M$. dalli and $M$. ionensis from each other, and hence, largely from the pronounced Gregariella features of $M$. ionensis, it has seemed best to place the three species under that section of Modiolus rather than to consider them under Modiolaria.

Length, $7.5 \mathrm{~mm}$.; width, $4 \mathrm{~mm}$.; diameter, $2.3 \mathrm{~mm}$.

Occurrence.-St. Mary's Formation. St. Mary's River.

Collection.-Maryland Geological Survey.

\section{Modiolus dalli n. sp.}

Plate XCTII, Figs. 9, 10.

Description.-Shell small, thin, delicate, somewhat perlaceous, vaulted, elongated; posterior dorsal margin subangulated at end, rest of margin rounded, posterior margin and posterior portion of basal margin strongly crenulated, anterior and dorsal margins partly faintly crenulated, midbasal margin smooth; ligament groove narrow, straight; interior of shell smooth; posterior and anterior areas of outer surface of shell sculptured with fine rounded radial threads reticulated or granulated by concentric lines, near posterior basal margin additional fine radial lines produced by branching or by intercalation between longer lines; posterior slope rudely undulose, especially in its superior portion; slope from beak to posterior basal margin distinctly elevated and ridged, anterior to which the surface is depressed or almost grooved at junction of sculptured and smooth areas; smooth area crossed by irregular concentric growth striæ; anterior radial sculpturing faint.

This species is much more produced, is thinner and more finely and delicately sculptured than $M$. virginicus, which is a compact, stout and somewhat coarsely sculptured species. It is named in honor of Dr. W H. Dall.

Length, $8.9 \mathrm{~mm}$.; height, $4.5 \mathrm{~mm}$.; diameter, $2 \mathrm{~mm}$.

Occurrence.-Choptank Fonination. Pawpaw Point.

Collection.-Maryland Geological Survey. 


\section{Modiolus IONENsis n. sp. \\ Plate XCVII, Figs. 11, 12.}

Description.-Shell small, exceedingly thin and fragile, highly perlaceous, translucent to nearly transparent, elongated, narrowed and curved, moderately inflated; beak depressed, not prominent; posterior portion of shell made oblique by strong arching of dorsal margin and incurving of basal margin; marginal crenulations entire except on a part of the basal margin ; those just anterior to the beak especially strong and almost like teeth: ligament groove very narrow, shallow and inconspicuous; interior of shell showing exterior radiating sculpture; exterior with broad area extending from beak to emarginate base and smooth except for faint concentric growth lines, this smooth area separating anterior and posterior radially sculptured areas; radial sculptured lines crossed by irregular concentric lines producing irregular granulation; umbonal slope back to posterior basal margin higinly elevated; medial smooth area flattened.

This species is more produced, much more delicate and fragile, and has a much more strongly incurved basal margin than $M$. dalli.

Length, 7 mm.; height, $3 \mathrm{~mm}$; depth, $1 \mathrm{~mm}$.

Occurrence.-Сhoptank Formation. Jones Wharf.

Collection.-Maryland Geological Survey.

Genus MODIOLARIA Beck.

Modiolaria curta n. sp.

Plate XCVII, Fig. 13.

Description.-Shell small, thin, fragile, pearly, short and compactly rounded, highly vaulted; radial sculpturing on dorsal and posterior portions very distinct, ridges broader than interspaces and flattened somewhat on top; sculpturing just beneath beak distinct; from beak to midbasal margin a broad area without radial sculpturing, but with concentric growth lines visible; beak high and slightly projecting; interior showing external radial ridging very distinctly.

Length, $3.8 \mathrm{~mm}$; height, $2.9 \mathrm{~mm}$.

Occurrence.-Calvert Formation. Plum Point.

Collection.-Cornell University. 


\section{Superfamily ANOMIACEA. \\ Family ANOMIIDE.}

Genus ANOMIA (Linné) Muiller.

ANomid smiplex d'Orbigny.

Plate XCVIII, Fig. 1.

Anomia simplex d'Orbigny (1845, Spanish ed.), 1853, Moll. Cubana, vol. ii, p. 367, pl. xxxviii, figs. 31-33.

Anomia ephippium var. Conrad, 1845, Fossils of the Medial Tertiary, p. 75 , pl. xliii, fig. 4 .

Anomie Conradi d'Orbigny, 1852, Prod. Pal. Strat., vol. iii, p. 134, pl. xxv, fig. 30.

Anomit ephippium Tuomey and IIolmes, 1855, Pleiocene Fossils of South Carolina, p. 18 , pl. v, fig. 4 .

Anomia ephippium Holmes, 1858, Post-Pleiocene Fossils of South Carolina, p. 11, pl. ii, fig. 11.

Anomice eplippizm Emmons, 1858, Rept. N. Car. Geol. Survey, p. 277.

Anomie Couradi Conrad, 1863, Proc. Acad. Nat. Sci. Phila., vol. xiv, p. 582.

Anomia Conradi Meek, 1864, Miocene Check List, Smith. Misc. Coll. (183), p. 4.

Anomit simplex Dall, 1889, Bull. xxxvii, U. S. Nat. Mus., p. 32, pl. liii, figs. 1, 2.

Anomic simplex Dall, 1898, Trans. Wagner Free Inst. Sci., rol. iii, pt. iv, p. 784.

Description.-Shell thin, translucent, irregularly circular in outline; superior valve strongly convex or inflated; exterior surface with very faint irregular concentric growth striations or, more commonly, smooth; within, byssal scars distinct, subequal, close; lower valve irregularly flat, with irregular concentric growth strix.

Length, $15 \mathrm{~mm}$.; width, $15 \mathrm{~mm}$; diameter, $6 \mathrm{~mm}$. (small upper valve).

Occurrence.-St. Mary's Formation. St. Mary's River.

Collection.-Maryland Geological Survey.

Axomia aculeata Gmelin.

Plate ICVIII, Figs. 2, 3, 4, 5 .

Anomia aculeata Gmelin, 1792, Syst. Nat., t. vi, p. 3346.

Anomia aculeata Gould, 1841, Invert. Mass., p. 139, tig. 90.

Anomia aculeata Gould (Binney's), 1570, Invert. Mass., p. 204, fig. 498.

Anomia aculeata Verrill, 1873, Rept. U. S. Fish Com. for 1871-2, p. 697, pl, xxxii, figs. 239-240a.

Anomit aculeata Dall, 1589, Bull, xxxvii, U. S. Nat. Mus., p. 32, pl. liii, figs. 5-8. Anomiu aculeuta Dall, 1898, Trans. Wagner Free Inst. Sci., vol, iii, pt. iv, p. 784. 
Description.-Shell irregularly rounded; upper valve irregularly and moderately convex, beak but slightly prominent and very near the margin, the external surface ornamented near the beak with fine, radiating, undulated lines of minute scales which become rounded pustules nearer the margins; within almost smooth: lower valve flat, smooth except for slight, irregular, concentric growth lines.

The shape varies according to the position occupied during growth but is usually irregular. A magnificent specimen of an upper valve from Plum Point, with beak broken, is very thick, symmetrical and profoundly and regularly elevated, being in height 45 , width 46 , and diameter $13 \mathrm{~mm}$. At several localities young specimens have been found that in some cases show the ornamentation of $A$. aculeata and have been referred to it, while in others no ornamentation has developed and they are considered as indeterminate, though most probably they are also the young of $A$. aculeata.

Height, usually about $37 \mathrm{~mm}$; width, $35 \mathrm{~mm}$., but see preceding description.

Occurrence.-S't. Mary's Formation. St. Mary's River, Cove Point (?). Сhoptank Formation. Jones Wharf, Trappe Landing (?). Calvert Formation. Plum Point, 3 miles south of Chesapeake Beach (?).

Collections.-Maryland Geological Survey, Johns Hopkins University, U. S. National Museum.

\section{Superfamily PECTINACEA.}

Family LIMID $Æ$.

Genus LIMA (Bruguière) Cuvier.

Lima Paprria Conrad.

Plate XCVIII, Fig. 6.

Lima papyria Conrad, 1841, Proc. Acad. Nat. Sci. Phila., vol. i, p. 30.

Lima papyria Conrad, 1845, Fossils of the Medial Tertiary, p. 76 , pl. xliii, fig. 7 .

Lima papyria Conrad, 1863, Proc. Acad. Nat. Sci. Phila., vol. xiv, p. 582.

Lima papyria Meek, 1864, Miocene Check List, Smith. Mise. Coll. (15:3), p. f. 
Description. - Obliquely obovate, thin and fragile, inflated; with prominent radiating lines, distant towards the anterior margin; anterior margin angulated at base of the ear, truncated or slightly concave below, and abruptly rounded where it joins the basal margin; ears small. . . Conrad, 1841.

This species has very rarely been collected. It seems confined to a thin band found here and there at an elevation of three or four fcet above tice in the cliff just south of Plum Point. It is very fragile and difficult to obtain entire.

Height, $25 \mathrm{~mm}$.; width, $21 \mathrm{~mm}$.; diameter, $7 \mathrm{~mm}$.

Occurrence.-Calvert Foraration. Plum Point.

Collection.-Maryland Geological Survey.

Family SPONDYLIDÆ.

Genus PLICATULA Lamarck.

Plicatula densata Conrad.

Plate XCVIII, Figs. \%, 8, 9.

Plicatula densata Conrad, 1843, Proc. Acad. Nat. Sci. Phila., vol. i, p. 311.

Plicututu densata Conrad, 1845, Fossils of the Medial Tertiary, p. 75, pl. xliii, fig. 6. Plicatula densata Conrad, 1863, Proc. Acad. Nat. Sci. Phila., vol. xiv, p. 582.

Plicutulu densuta Meek, 1864, Miocene Check List, Smith. Misc. Coll. (183), p. 4.

Plicatule densatu Whittield, 1894, Mon. xxiv, U. S. Geol. Survey, p. 35, pl. v, figs. $3-8$.

Plicutula densutu Dall, 1898, Trans. Waqner Free Inst. Sci., vol. iii, pt. iv, p. 763.

Description._" Ovate, thick, profoundly and irregularly plicated; inferior valve ventricose; ribs acute, with arched spiniform scales; cardinal teeth large, curved, laterally striated, crenulated on the margins; larger cardinal tooth in each valve slightly bifid, broad; muscular impression prominent. . . The valves have about ten folds, and the lower valve closely resembles a variety of Ostrea Virginiana." Conrad, 1843.

This species is distinguished from the P. marginata Say, by its broader, rounder, flatter form, more irregular and less prominent as well as finer plications and greater tendency to lateral curvature of the beaks.

Length, $3 \% \mathrm{~mm}$; width, $31 \mathrm{~mm}$.; diameter, $6 \mathrm{~mm}$.

Occurrence.-Calvert Formation. Church Hill.

Collections.-Maryland Geological Survey, Johns Hopkins University. 


\section{Family PECTINID代.}

Genus PECTEN Müller.

Subgenus PECTEN ss.

\section{Pecter (Pecten) humpiremsil Conrad.}

Plate XCVIII, Figs. 10, 11, 12.

I'ceten Ilnmphreysii Conrad, 1842, Proc. Nat. Inst., Bull. ii, 1. 194, pl. ii, fig. 2.

Vola Humphreysii Conrad, 1863 , Proc. Acad. Nat. Sci. Phila, vol. xiv, p. 582.

Pecten Humplreysii Meek, 1864, Miocene Check List, Smith. Misc. Coll. (183), 1. 4.

Iolt IIm) tereysii Whitfield, 1894, Mon. xxiv, U. S. Geol. Survey, pp. 32-34, pl. iv, figs. 6-!).

Perten (Pecten) Humphreysii Dall, 1898, Trans. Wagner Free Inst. Sci., vol. iii, pt. iv, pl. 720,721 .

Description._- Suborbicular, inferior valve convex; superior flat, and with about seven remote, narrow, convex ribs, and concentrically wrinkled; towards the apex is a concave depression; ears equal, sides direct and straight; inferior valve with the ribs wide, approximate, plano-conver and longitudinally striated; one of the ears emarginate at the base." Conrad, 1842.

The inferior valve has nsually seven or eight broad elevated ribs, one with eleven ribs, however, was much less convex, showing probably that the requisite strength having been obtained by an increase in the ribbing, the marked convexity characteristic of the seven ribbed valves was no longer necessary. Fine concentric striæ are very characteristic of the upper valve and are simulated by the concentric growth lincs of the lower one.

Length, $110 \mathrm{~mm}$; width, $125 \mathrm{~mm}$.

Occurrence.-Caliert Fonalition. Fair Haven, Lyon's Creek, Chesapeake Beach, Plum Point, 'Truman's Wharf, White's Landing, Reed's, Centerville, Burch (Dall), (not abundant).

Collections.-Maryland Geological Survey, Johns Hopkins University, U. S. National Museum.

Subgenus AMUSIUM Bolten.

Pecten (Amusium) arortoni Ravenel.

Plate ICIX, Fig. 1.

Pecten Wortoni Ravenel, 1844, Proc. Acad. Nat. Sci. Phila., vol. ii, p. 96.

Pecten Hortoni Tuomey and Holmes, 185.5, Pleiocene Fossils of South Carolina, p. 27, pl. x, figs. 1,2 . 
Peeten Wortoni Emmons, 1858, Rept. N. Car. Geol. Survey, ]. 2\$1.

Amusium Mortoni Conrad, 1863, Proc. Acad. Nat. Sci. Phila,, vol, xiv, p. 58:. Ammsirm Lortoni Meek, 1864, Miocene Check List, Smith. Misc Coll. (183), 1. 4. Pecten (Amusium) Mortoni Dall, 189s, Trans. Wagner Free Inst. Sci., vol. iii, pt. iv, p. $\tau 5 \%$.

Description._-" Orbicular, thin, both valves moderately convex, one more so than the other-outside, with numerous concentric obsolete striæ; inside, - with from eighteen to twenty-four radiating double ribs, slightly elevated; ears large, subequal, striated externally." Ravenel, 1844 .

This large, thin, flattened species is rarely obtained entire. It is quite rare in Maryland, the Survey having no specimens. A few broken preces in the National Museum are labelled "Fairhaven and Cove Point." These specimens are probably from Cove Point and the reference to Fairharen a mistake, since the two localities are separated geographically by about thirty miles and stratigraphically by about almost the entire Maryland Miocene column, rendering it unlikely that through accidental admixture part of the material came from one place and part from the other. The character of the shell substance in the specimens is sound and not unlike that found at Cove Point; while in the Fairhaven cliffs all the shells have entirely lost their shell substance through decay and cxist only as casts, except Ustrea percrassu, in which the shell substance is still present but very badly decayed, and Discinisca lugubris which is here as everywhere else still fresh and polished.

Length, - the fragments indicate a length of about $160 \mathrm{~mm}$.

Occurrence.-Str. Mary's Formation. Cove Point.

Collection.-U. S. National Museum.

Subgenus PSEUDAMUSIUM H. and A. Adams.

Pecten (Pseudanusium) cerinus Comrad.

Plate XCIX, Fig. 2.

Pecten cerinus Conrad, 1869, Amer. Jour. Conch., vol. v, p. 39, pl. ii, fig. 2.

Pecten (Pseulumesium) cerimes Dall, 1898, Trans. Wagner Free Inst. Sc1., vol. iii, pt. 1v, p. $75: 3$.

Description.- "Subovate, extremely thin, compressed; ears equal; right valve radiately ribbed; ribs very slightly raised and rounded; surface ornamented by minute, close divaricating lines, left valve without ribs." Conrad, 1869. 
"Shell small, thin, polished, compressed; left valve more convex, with about twenty faint, flat, rather irregular obsolete ribs, separated by narrower, shallow sulci, the whole surface with minute Camptonectes striation; right valve with concentric incremental lines and a few faint threads near the beaks and anterior submargin; ears small, subequal; ctenolium present; cardinal and auricular crura developed; interior of left valve faintly fluted, but without liræ. . . .

"In some of the specimens there are a few feeble concentric undulations near the beak of the left valve." Dall, 1898.

Length, $19 \mathrm{~mm}$; width, $18 \mathrm{~mm}$.

Occurrence.-Choptank Formation. Jones Wharf. Calvert Foriration. Plum Point, Charles county near the Patuxent river (fide Cope). (Very rare and quite small.)

Collections.-Maryland Geological Survey, U.S. National Museum, Philadelphia Academy of Natural Sciences.

\author{
Subgenus CHLAMYS Bolten. \\ Section CHLAMYS ss. \\ Pecten (Chlamis) coccramelus Dall. \\ Plate XCIX, Fig. 3. \\ Pecten (Chlemys) cocymelus Dall, 189s, Trans. Wagner Free Inst., vol, iii., pt. iv,
} 1. $7+1$, pl. xxxiv, fig. 1.

Description._ " Shell small, ovate, inflated, strongly sculptured, with unequal ears; disk with eightecn narrow, high compressed ribs, with wider interspaces, which near the basal margin carry one or two very small radial threads; the backs of the ribs support numerous high, evenly spaced, distally guttered, small spines; in the interspaces only transverse sculpture of wary incremental lines; submargins small, narrow, with fine, beaded radial threads, which in the left valve also extend over the ears; hinge line short, the cardinal crura developed, sharply crossstriated; auricular crura present; interior of the disk fluted in harmony with the external ribs. ...

"A single left valve of this elegant species was obtained. From the young of $P$. Madisonius, which sometimes approach it, it is easily distinguished by its more oval and inflated form, nearly smooth interspaces, and compressed ribs." Dall, 1898. 
Gradient forms show a close genetic relationship with $P$. madisonius as found in the Calvert formation.

Length, $30 \mathrm{~mm}$; width, $25 \mathrm{~mm}$; diameter, $5 \mathrm{~mm}$.

Occurrence.-Calvert Formation. Plum Point, Chesapeake Beach, 3 miles south of Chesapeake Beach.

Collections.-Maryland Geological Survey, Johns Hopkins University, U. S. National Museum.

Section NODIPECTEN Dall.

Pecten (Chlamys) rogersi Conrad.

Plate XCIX, Fig. 4.

Pecten Rogersii Conrad, 1834, Jour. Acad. Nat. Sci. Phila., vol. vii, 1st ser., p. 151. Peeten Rogersii Conrad, 1840, Fossils of the Medial Tertiary, p. 45, pl, xxi, fig. 9. Pecten Rogersi Conrad, 1863, Proc. Acad. Nat. Sci. Pbila., vol. xiv, p. 581.

Pecten Rogersi Meek, 1864, Miocene Check List, Smith. Misc. Coll. (183), p. 4.

Pecten (Nodipecten) Rogersi Dall, 1898, Trans. Wagner Free Inst. Sci., vol. iii, pt. iv, p. 730 .

Description.- "Shell ovate, compressed; with four very large and broad convex ribs and numerous radiating lines; ears small. Length and height, one inch and one-eighth." Conrad, 1834.

"Shell with four large and two smaller lateral simple ribs; internally lirate; submargins narrow, minutely scabrous, not radiated; the rest of the disk entirely covered with fine, squared, elevated, minutely scaly radial threads; ears subequal, finely radiated; sinus well-marked; ctenolium and cardinal crura developed." Dall, 1898.

Length, about $13 \mathrm{~mm}$., specimen broken and young.

Occurrence.-Choptank Formation(?). Near Skipton.

Collection.-U.S. National Museum.

Section PLACOPECTEN Verrill.

Pecten (Chlamys) clintonius Say.

Plate XCIX, Fig. 5.

Pecten Clintonius Say, 1824, Jour. Acad. Nat. Sci. Phila., vol. iv, 1st ser., 1. 135, pl, ix, fig. 2.

Pecten Clintonius Conrad, 1840, Fossils of the Medial Tertiary, p. 47, pl, xxiii, fig. 1. Pecten Clintonius Conrad, 1863, Proc. Acad. Nat. Sci. Phila,, vol. xiv, p. 581.

Pecten Clintonensis Meek, 1864, Miocene Check List, Smith. Misc. Coll. (183), p. 5.

Pecten (Plucopeeten) Clintonius Dall, 1898, Trans. Wagner Free Inst. Sci., vol. iii, pt. iv, p. 725 . 
Description._- Auricles equal; surface with from one hundred and forty to one hundred and eigluty elevated longitudinal lines.

"Shell suborbicular, compressed, with very numerous, regular, elevated striæ, which are muricated with minute scales formed by transverse wrinkles, that are sparse in the middle of the length, and crowded each side of the shell; the intervening spaces are regularly coneave, and in parts very distinctly wrinkled: auricles equal, striated like the general surface: within simple, margin striated." Say, 1824.

This flattened, thin, finely striated shell is very rare in Maryland. It is given on the authority of Dr. Foreman who gave no locality, however. No other one has reported it from the State.

Length, about $100 \mathrm{~mm}$. ; width, rather more (Say).

\section{Pecten (Chlamis) marylandicus Wagner.}

\section{Plate XCIX, Fig. 6.}

Pecten Hurylumdicus Wagner, 1839, Jour. Acad. Nat. Sci. Phila., vol. viii, 1st ser., p. 51, pl. [2], fig. 2. (Possibly printed pricately in 183\$.)

Pecten temis H. C. Lca, 1845, Trans. Amer. Philos. Soc., vol. ix, p. 246, pl. xxxv, fig. 33.

Perten Wurylundices Conrad, 1863, Proc. Acad. Nat. Sci. Phila., vol. xiv, p. 581.

Pecten tenuis Conrad, 1863, Proc. Acad. Nat. Sci. Phila., rol. xiv, 1) 581.

Peeten marylandires Meek 1864 , Miocene Check List, Smith. Misc. Coll. (183), p. 4. Perten tenuis Meek, 1864, Miscene Check List, Smith. Misc. Coll. (183), p. 4.

Perten (Placopecten?) murylandiens Dall, 1898, Trans. Wagner Free Inst. Sci., vol. iii, pt. iv, P. ז28.

Description._-"Shell ovate, compressed; ribs numerous, consisting of nar'row, nearly smooth strix, disposed in pairs; interstitial spaces each with a carinated line; ears unequal; inferior valve very slightly convex; ribs similar to those of the opposite valve; inner margin of the valve with profoundly elevated lines.

"T'his Pecten is allied to Pecten Madisonius Say, but can readily be distinguished by its want of broad, elevated ribs, and a surface destitute of scales...." Wagner, 1839 .

A comparison of numerous specimens shows that the lower valve is more convex than Wagner's description would indicate. The upper valve is but slightly convex, and its ear has the byssal notch well marked. "The interior of each valve is gently fluted in harmony with the external ribs. 
Length, 69 mm.; width, $6 \% \mathrm{~mm}$; diameter, $11 \mathrm{~mm}$.

Occurrence.-СhoptanK Formation. Governor Run, 2 miles sonth of Governor Rum, Flag Pond, St. Leonard Creek, Jones Wharf, Dover Bridge. Calnert Formation. White's Landing; near Friendship in railway cutting.

Collections.-Maryland Geological Survey, Johns Hopkins University, Philadelphia Academy of Natural Sciences.

\section{Section LYROPECTEN Conrad.}

\section{Pecten (Chlaniss) madisonits Say.}

\section{Plate C, Fig. 1.}

Pecten Marlisonins Say, 18:4, Jour. Acad. Nat. Sci. Phila., vol. iv, 1st ser., 1) 134.

Peten Madisonius Conrad, 1840, Fossils of the Medial Tertiary, p. 48, pl. xxiv, fig. 1.

Pecten Wudisonius Emmons, 1858, Rept. N. Car. Geol. Survey, 1. '282, fig. 200.

Pecten Matismius Conrad, 1863, Proc. Acad. Nat. Sci. Phila., vol. xiv, p. 581.

Pecten Mulisonius Meek, 1864, Miocene Check List, Smith. Mise. Coll. (183), P. 4.

Perten Mudisonius Whitfield, 1894, Mon. xxiv, U. S. Geol. Survey, p. 30, pl. ir, figs. $1-5$; pl. ii, tig. 8.

Pecten (Lympecten) Matixonirs Dall, 1898, Trans. Wagner Free Inst. Sci., vol. iii, pt. iv, p. 724 .

Description._" Much compressed, with about sixteen striated ribs.

"Shell rounded, much compressed; the whole surface covered with scaly striæ: ribs elevated, rounded, with about three striæ on the back of each; intervening grooves raiher profound: ears equal, sinus of the ear of the superior valve profound, extending at least one-third of the length of the ear." Say, 1824.

The ribs are usually about sixteen or seventeen, but occasionally as few as twelve; lower valve convex, upper one nearly flat. The young from the Calvert formation often have but one prominent elevated spinose line on the back of each rib, with a faintly marked one on either side especially near the margin of the shell. A series of intermediate specimens from here shows a close relationship with $P$. coccymelus found at the same horizon. Another series of intermediate forms from the Choptank formation suggests a relationship to the $P$. marylandicus found at that horizon. From $P$. madisonius is probably descended $P$. jeffersonius, the ofishoot oceurring in the St. Mary's formation probably, so that the transitional forms found here render the discrimination of the two 
species difficult at this horizon. For criteria for this discrimination see remarks under $P$. jeffersonius.

Length, $160 \mathrm{~mm}$; width, $200 \mathrm{~mm}$; diameter, $40 \mathrm{~mm}$.

Occurrence.-St. Marr's Formation. Cove Point, St. Mary's River, Iangley's Bluff (Dall). Choptank Formation. Governor Run, 2 miles south of Governor Run, Flag Pond, Jones Wharf, Cuckold Creek, St. Leonard Creek, Turner, Pawpaw Point, Sand Hill, Dover Bridge, Trappe Landing, Peach Blossom Creek, Cordova, Greensboro (Md. Geol. Sur.) ; near Skipton (Dall). Calvert Formation. Fairhaven, Chesapeake Beach, 3 miles south of Chesapeake Beach, Plum Point, Truman's Wharf, Church Hill, 3 miles west of Centerville, Reed's, White's Landing, Wye Mills, Lyon's Creek, Magruder's Ferry.

Collections.-Maryland Geological Survey, Johns Hopkins University, U. S. National Museum, Philadelphia Academy of Natural Sciences.

\section{Pecten (Chlamis) Jeffersonids Say. \\ Plate C, Fig. 2.}

Pecten Jeffersonius Say, 1824, Jour. Acad. Nat. Sci. Ph1la., vol. iv, 1st ser., p. 133, pl. ix, fig. 1.

Perten Jeffersonius Conrad, 1840 , Fossils of the Medial Tertiary, p. 46, pl. xxii, fig. 1. Pecten Jefforsonius Emmons, 1858, Rept. X. Car. Geol. Survey, p. :88, fig. 199. Terten Jeffersonius Conrad, 1863, Proc. Acad. Nat. Sci. Phila., vol. xiv, p. 581. Perten Jeffersonius Meek, 1s64, Miocene Check List, Smith. Misc. Coll. (183), 1. 4. Peten (Lyropecten) Jeffersonius Dall, 1s98, Trais. Wagner Free Inst. Sci., rol. iil, pt. ir, 1. 722.

Description._-"Subequivalve, with from nine to eleven striated ribs.

"Shell rounded, convex, not quite equivalved, one of the valves being a little more convex than the other; the whole surface covered with approximate sealy striæ: ribs elevated, rounded, with six or seven striæ on the back of each; intervening grooves profound: ears equal; sinus of the ear of the superior valve, not profound, being barely one-eighth part of the length of the ear: within with broad rounded flattened ribs." Say, 1824.

This species is very probably a descendant of $P$. madisonius and is at times hard to distinguish from it. In general, jeffersonius is the more convex, the upper and lower valves being nearly equi-convex; while in madisonius the upner valve is flatter than the lower. The ribs of jeffer- 
sonius are broader and the radial threads finer and more numerous. The best criterion, however, for their separation is found in the character of the byssal ear. "In Jeffersonius it is sculptured with fine, uniform, numerous threads, and the notch is shallow and leaves an inconspicuous fasciole. In Madisonius the upper part of the ear is provided with comparatively few and coarse threads, and the notch is wide and deep with a broad and well marked fasciole." Dall, loc. cit.

Length, $130 \mathrm{~mm}$.; width, $140 \mathrm{~mm}$.; diameter, $25 \mathrm{~mm}$., though often found considerably larger.

Occurrence.-St. Mari's Formatiox. St. Mary's River.

Collertions.-Maryland Geological Survey, Johns Hopkins University.

Pecten Jeffersonius var. edgecombensis (Conrad).

Plate C, Fig. 3.

Peeten Edgecomensis Conrad, 156:2, Proc. Acad. Nat. Sci. Phila., vol. xiv, p. 291.

Peeten edgecomensis Courad, 1863, Proc. Acad. Nat. Sci. Phila., vol. xiv, p. 581.

Pecten Jeffersonius mar. edgecomensis Dall, 1898, Trans. Wagner Free Inst. Sci., vol. iii, pt. is, p. ร22.

Description.- "Suborbicular; height not quite equal to the length; lower valve-ribs 16 to $1 \%$, prominent, but not elerated, square or conrexdepressed, not quite as wide as the intervening spaces, radiately lined with finely squamose striæ, most conspicuous towards the margins, interstices of ribs carinated, in the middle squamose and finely striated; ears with fine close unequal squamose radiating lines, the larger ones prominent on the posterior side; margins of ligament pit carinated." Dall, 1898.

The number of ribs in this variety varies from twelve to seventeen or occasionally more. In the middle of the spaces between the ribs the fine radial stria become somewhat larger.

Length, $170 \mathrm{~mm}$; width. $195 \mathrm{~mm}$; diameter, $30 \mathrm{~mm}$.

Occurrence.-St. Mary's Formation. St. Mary's River, Langley's Bluff.

Collections.-Maryland Geological Survey, U. S. National Museum.

Pecten Jeffersonius var. septenarius Say.

Plate C, Fig. 4.

Pecten septenarius Say, 1824, Jour. Acad. Nat. Sci. Phila., vol. iv, 1st ser., p. 136, pl. ix, fig. iii. 
Pecten septemeurius Conrad, 1840, Fossils of the Medial Tertiary, p. 47, pl. xxii, fig. '2.

Pecten septenurius Tnomey and Holmes, 1856, Pleiocene Fossils of South Carolna, p. 31, pl. xiii, figs, 1-4.

Perten septenurius Conrad, 1863, Proc. Acad. Nat. Sei. Phila., vol. xiv, 1. 5\$1.

Pecten septenurius Meek, 1 s64, Miocene Check List, Smith. Mise. Coll. (183), 1). 4.

Pecten Jeffersonius eur. septemarius Dall, 1898, Trans. Wagner Free Inst. Sci., vol. iii, pt. iv, 1. 722.

Description.- "Shell convex, suborbicular: auricles subequal: surface with numerous slightly scaly striæ, and about seven remote ribs, of which the three intermediate ones are much elevated, rounded or slightly flattened on the top.

"The striæ are equally distinct on the ribs, and in the intermediate spaces. The scales are rather thick, very small, and not confined to the striæ, but are also observahle in the spaces between the striæ." Say, 1824.

In the young the ribs are flat-topped, transversely angular, and as broad across the top as at the base or even broader. In the old the ribs beeme more rounded transversely. Number of ribs seven or eight.

Height, $90 \mathrm{~mm}$. ; width, $93 \mathrm{~mm}$. ; diameter, $21 \mathrm{~mm}$.

Occurrence.-St. Mary's Formation(?). St. Mary's River(?).

Collections.-Maryland Geological Survey, U. S. National MInsemm.

\section{Superfamily OSTRACEA.}

\section{Family OSTREIDÆ.}

Genus OSTREA Lamarck.

Ostrea sellaforitis var. thomasit (Comrad).

Plate C, Figs. 5a, 5b.

Ostrea thomasit Conrad, 1stit, Proc. Acad. Nat. Sci. Phila., vol. xix, p. 139 (listed only).

Description.-Shell small, thin to moderately thick, fan-shaped to pear-shaped in ontline; beaks laterally curved; ligament groore excavated; ribs on lower valve fifteen to twenty, of thin imbricated scales somewhat elevated; each margin in the lower valve just backward from the hinge line marked by a short punctate impressed line; upper valve thin, slightly convex, surface concentrically marked by the edges of the 
thin flat lamellæ; margins near the beak transversely denticulated or striated.

This is one of the species named by Conrad and published by Cope (loc. cit.) that has never been described. The original specimens from Charles county are in the Academy of Natural Sciences in Philadelphia.

This shell is closely allied to the upper Oligocene varieties of $O$. sellaformis and may be considered an early Miocene variety of the same species.

Length, $58 \mathrm{~mm}$; width. $43 \mathrm{~mm}$. ; diameter, $15 \mathrm{~mm}$.

Occurience.-Calvert Formation. Charles county near the Patuxent river (Cope); Plum Point, Truman's Wharf, Chesapeake Beach, 3 miles south of Chesapeake Beach.

Collections.-Maryland Geological Survey, Johns Hopkins University, U. S. National Musenm, Philadelphia Academy of Natural Sciences.

\section{Ostrea trigonilis Conrad.}

Plate CI, Figs. 1a, 1b.

Ostrea trigonalis Con rad, 1854, Wailes' Rept. Agric. and Geol. Miss., p. 289, pl. xiv, fig. 10 (name and figure only).

Ostren trigonalis Conrad, 1855, Proc. Acad. Nat. Sci. Phila., vol. vii, p. 259.

Ostrea trigonalis Dall, 1s98, Trans. Wagner Free Inst. Sci., vol. ii, pt. iv, p. 681.

Description._"Triangular, flat, surface irregular, with some indistinct radiating lines; muscular impression obliquely suboval, sitnated nearer the summit than the base; margin somewhat ascending, submargin carinated." Conrad, 1855 .

"The species is wide spread and recognized by its flat upper valve, few-ribbed lower valve, straight hinge line, flat hinge area, with excavated central channel and the peculiar vermicular sculpture of the submargin on each side near the hinge line." Dall, 1895.

Length, $90 \mathrm{~mm}$.; width, $70 \mathrm{~mm}$.

Occurrence.-СHортаNк Formation. Jones Wharf, Greensboro (rare in Maryland).

Collections.-Maryland Geological Survey, U. S. National Musemm.

\section{Ostrea carolinensis Conrad.}

Plate CI, Figs. 2, 3, 4.

Ostrea Curolinensis Conrad, 1832, Fossil Shells of the Tertiary, p. 27, pl. xiv, fig. 1. Ostrea rombensis Dall, 1898, Trans. Wagner Free Inst. Sci., vol. iii, pt. ir, p. 686. 
Description._" Obovate, oblique, thick, compressed; superior valve flat; inferior valve conrex, with concentric imbricated lamellæ which are transversely plicated; beaks broad and prominent; fosset large and defined by broad prominent lateral ridges." Conrad, 1832.

'T'he Maryland specimens are smaller and usually thinner than the original Carolina ones. The ribs are fine and regular on some, on others irregular. The submargin of the upper valve near the beaks is transversely striated. This species is often very abundant.

Length, $100 \mathrm{~mm}$.; width, $75 \mathrm{~mm}$; diameter, $25 \mathrm{~mm}$.

Occurrence.-St. Marr's Formation. St. Mary's River(?). ChopTank Formation. Governor Run, 2 miles south of Governor Run, Flag Pond, Jones Wharf, Turner, Cuckold Creek, St. Leonard Creek, Peach Blossom Creek, Dover Bridge.

Collections.-Maryland Geological Survey, Jolons Hoplins Tniversity, U. S. National Museum.

\section{Ostrea percrassa Conrad. \\ Plate CII, Figs. 1, 2.}

Ostree pererasse Conrad, 1840, Fossils of the Medial Tertiary, p. 50, pl. xxv, fig. 1. Osteet pereresse Con rad, 1s68, Proc. Aead. Nat. Sci. Phila., vol. xiv, p. 5s:.

Ostren pereresse Meek, 1S64, Miocene Check List, Smith. Misc. Coll. (183), p. 3.

Ostren percorsse. Heilprin, 1s8t, th Ann. Rept. U. S. Geol. Survey, 1). 313, pl. lxvii, fig. 3 .

Ostice pererusse Whitfield, 1894 , Mon. xxiv, U. S. Geol. Survey, 1. 29, pl. iii, figs. $1-4$.

Ostrea peverasse Dall, 1s9s, Trans. Wagner Free Inst. Sci., vol, iii, 1,t. iv, p. 6s:3.

Description.- "Shell extremely thick and ponderous; hinge very broad; cartilage fosset wide and shallow; muscular impression exhibiting a rery profound cavity." Conrad, 1840 .

Lower valve convex exteriorly, deeply concave within; upper valve more nearly flat; shell substance of innumerable fine lamellæ, often the home of boring forms.

Length, $110 \mathrm{~mm}$.; width, $95 \mathrm{~mm}$.; diameter, $40 \mathrm{~mm}$.

Occurrence.-Calvert Formation. Chesapeake Beach, 3 miles south of Chesapeake Beach, Plum Point, Hollin Cliff, Magruder Ferry, White's Landing, Reed's, Fairhaven, near Friendship. Milltown Landing.

Collections.-Maryland Geological Survey. Johns Hopkins University, Cornell UTniversity. 
Ostrea sp.

In addition to the above described species of Ostrea some indeterminate valves were obtained at Church Hill, Skipton, and three miles west of Centerville.

\section{Superfamily PTERIACEA. \\ Family MELINID Æ. \\ Genus MELINA Retzius.}

Melina maxiliata (Deshayes).

Plate CII, Fig. 3 ; Plate CIII, Fig. 1.

Perna maxillata Lamarck, 1819, An. sans Vert., vi, i, p. 142, (syn. excl.): ed. Deshayes, 1836, vii, p. 78 (fide Dall).

Perna torta Say, 1820, Amer. Jour. Sci., vol. ii, p. 38.

Perna maxilluta Conrad, 1840, Fossils of the Medial Tertiany, p. 52, pl. xxvii, fig. 1.

Isognomon torta Conrad, 1863, Proc. Acarl. Nat. Sci. Phila., vol. xiv, p. 579.

Melina torta Meek, 1864, Miocene Check List, Smith. Misc. Coll. (183), p. 6.

Perna torta Whitfield, 1894, Mon. xxiv, U. S. Geol. Survey, p. 36, pl. v, figs. 12, 13.

Melina maxillata Dall, 1898, Trans. Wagner Free Inst. Sci., vol. iii, pt. ir, p. 667.

Description.-Shell angularly pointed and slightly curved anteriorly, posteriorly ovate, surface moderately convex, with irregular shallow concentric undulations marking growth lines; ventral edge thickened and somewhat inrolled; ligament area broad with fifteen to twenty shallow transverse grooves; exterior covered by a thin prismatic layer, interior layer pearly, thick, composed of many thin shelly laminæ, interior surface nacreous.

This shell is very rarely obtained entire. The prismatic layer is almost always gone entirely, and of the shelly, pearly portion, only the heavy anterior part is usually preserved. The shell is very often bored by Martesia ovalis and other burrowing forms. Perfect valves are very rare but may be obtained at Plum Point. Jones Wharf or Pawpaw Point at water level.

Length, $165 \mathrm{~mm}$.; width, $90 \mathrm{~mm}$; diameter, $17 \mathrm{~mm}$., though fragments of larger individuals are often found.

Occurrence.-St. Mary's Formation (?). Cove Point (?). Choptank Formation. Governor Run, Jones Wharf, Pawpaw Point, Dover Bridge, Greensboro, Cordova, Skipton, St. Leonard Creek. CaLvert 
Formation. Church Hill, 3 miles west of Centerville, Chesapeake Beach, Plum Point, Hollin Cliff, Reerl's. White's Landing.

Collections.-Marrland Geological Survey, Johns Hopkins University, U. S. National Musemm. Philadelphia Academy of Natural Sciences.

\section{Family PINNID/瓜. \\ Genus ATRINA Gray. \\ Atrina harrisit Dall. \\ Plate CIII, Figs, 2, 3.}

Atrima Horrisii Dall, 1S95, Trans. Wagner Free Inst. Sci., vol. iii, pt. jv, p. 663, pl. xxix, tig. 11.

Description._- Shell rather thick (the fibrous layer lost in the specimens), ovately rounded behind, moderately conver; hinge line straight, ventral margin slightly incurved; the surface of the pearly layer shows the dorsal region with numerous fine longitudinal elevated lines, below which the shell is at first nearly smooth, then the rentral region is sculptured with numérous close-set concentric riblets. Length of portion preserved about 150, max. width 60, diam. 32 mm." Dall, 1898.

More perfect specimens show the hinge line to be slightly convex; the fine lines dorsally become obsolete toward the posterior end, the prismatic layer there showing only faint irregular concentric growth riblets that become stronger on the rentral slope; prismatic layer thin; ventral margin thickened and angularly ineurved.

Length, about $170 \mathrm{~mm}$. ; width, $85 \mathrm{~mm}$.; diameter, $28 \mathrm{~mm}$.

Occurrence.-Снортахк Formation. Pawpaw Point, Jones Wharf. Caliert Formatiox. Plum Point, Truman's Wharf, Chesapeake Beach, White's Landing.

Collections.-Maryland Geological Survey, Johns Hopkins University, U. S. National Ifuseum, Philadelphia Academy of Natural Sciences.

\section{Atrina pischtoria n. sp.}

Plate CIT, Fig. 1.

Description.-Pearly layer of shell thin, prismatic layer thick; moderately conver, rounded posteriorly; hinge line nearly straight; rentral margin incurved; rentral and dorsal margins forming an angle of about 
45 degrees with each other; dorsal region smooth; rentral region sculptured by rather distant irregularly spaced concentric riblets.

This is much larger and broader and less acute anteriorly than A. harrisii, and is withont the fine parallel lines characteristic of the dorsal region in that species. The specimen had been flattened so that the diameter given below is less than the true diameter.

Length, about $200 \mathrm{~mm}$.; maximum width. about 120 $\mathrm{mm}$.; diameter, $25+\mathrm{mm}$.

Occurrence.-Calvert Forantion. Chesapeake Beach.

Collection.-Maryland Geological Survey.

\section{Superfamily ARCACEA.}

\section{Family ARCIDAE.}

\section{Subfamily ARCIN/E.}

Genus ARCA (Linné) Lamarck.

Subgenus SCAPHARCA (Gray) Dall.

Section ANADARA Gray.

Arca (Scapharca) subrostrata Conrad.

Plate CIT, Figs. 2, 3a, 3b.

Area subrostrutu Conrad, 18+1, Proc. Acad. Nat. Sci. Phila., vol. i, p. 30.

Area subrostrate Conrad, 1842, Jour. Acad. Nat. Sci. Phila., vol. viii, 1st ser., p. 185. Area subrostruta Conrad, 1845, Fossils of the Medial Tertiary, p. 58, pl. xxx, fig. 7. Scapharca subrostrata Conrad, 1863, Proc. Acad. Nat. Sci. Phila., vol. xiv, 1. 580. Scapharca subrostrata .Meek, 1864, Miocene Check List, Smith. Misc. Coll. (183), p. 6. Scapharea tenuicerdo Conrad, 1869, Amer. Jour. Conch., vol. v, p. 39, pl, ii, tig. 4. Scapharca subrostrata Whitfield, 1894, Mon. xxir, U. S. Geol. Survey, p. 45, pl. vi, figs. 11-13.

Scupharea (Anudara) subrostrata Dall, 1898, Trans. Wagner Free Inst. Sci, vol. iii, pt. iv, P. 655 .

Description._" Ovate; profoundly ventricose; ribs about 30, little prominent, flat, longitudinally sulcated; posterior side produced, cuneiform; rounded at the extremity; hinge linear in the middle, teeth obsolete, except towards the extremities; within slightly sulcated; crenulations of the margin sulcated in the middle." Conrad, $18+1$.

Cardinal area grooved with numerous somewhat irregular, though nearly parallel grooves; posterior umbonal slope angulated near the 
umbo, rounded near the base; ribs sulcated by a strong median groove, supplemented usually by a finer groove on either side of the median one; posterior side flattened, ribs there but slightly prominent.

Length, $53 \mathrm{~mm}$; height, $34 \mathrm{~mm}$. ; diameter, $15 \mathrm{~mm}$.

Occurrence.-Calvert Formation. Chesapeake Beach, 3 miles south of Chesapeake Beach, Plum Point, Truman's Wharf, White's Landing, Church Hill, 3 miles west of Centerville, Reed's, Wye Mills, near Skipton.

Collections.-Maryland Geological Survey, Johns Hopkins University, U. S. National Museum.

\section{Arca (Scapharca) Elnia n. sp.}

Plate CIV, Figs. 4a; $4 \mathrm{~b}$.

Description.-Shell large, moderately thick, but slightly elongated, not inflated, with prominent prosocœlous beak; cardinal area wide, with numerous irregular, zigzag, longitudinal grooves, bounded by a single deep curved groove from the beak to the ends of the hinge line; hinge line narrow; teeth small, obsolete medially, tending to become irregnlar at both ends of the series: right valve with about thirty-one low ribs hardly as wide on anterior dorsal slope as intervening spaces, broader and more elevated on posterior dorsal slope; each rib mesially sulcated by a groove with one or more subordinate grooves on either side; growth lines distinct; margin a continuous curve from anterior end of hinge line to posterior end of base, there sharply curved; posterior margin oblique to hinge line; interior margin crenulated; dorsal and posterior slopes meet in an angle that becomes rounded near the basal margin.

This species seems to be intermediate between $A$. staminea and A. subrostrata, being perhaps more nearly related to the latter.

Length, $60 \mathrm{~mm}$; height, $48 \mathrm{~mm}$; diameter, $22 \mathrm{~mm}$.

Occurrence.-СHoptank Formation. Jones Wharf, lower bed at Governor Run, 2 miles south of Governor Run.

Collection.-Maryland Geological Survey.

Arca (Scapharca) clisea Dall. Plate CV, Fig. 1.

Scapharca (Anadara) clisea Dall, 1898, Trans. Wagner Free Inst. Sci., vol. iii, pt. iv, p. 657, pl. xxxiii, fig. 25. 
Description._-"Shell large, heavy, inflated, short, with small, high, somewhat prosoccelous bealks, the two halves of the wide cardinal area inclined to one another in the adult at an angle of about forty-five degrees; left valve with about thirty strong, flattened subequal radial ribs with narrower interspaces; in the young the ribs are furnished with small transverse nodulations, which gradually become obscure in the adult; the only transverse sculpture is of the ordinary incremental lines; the ribs in the adult are flat-topped and rarely show any tendency to mesial sulcation, and when present it appears only on a few of the anterior ribs near the margin: the anterior end is obliquely rounded to the base, the posterior end a little produced basally; the cardinal area is exceptionally wide, with a single impressed line joining the beaks and six or seven concentric lozenges defined by sharp grooves; a deep groove also bounds the area; hinge line straight with numerous small vertical teeth, becoming much larger distally and tending to break up into granules at both ends of the series in the senile shell. ..." Dall, 1898.

This shell seems more closely related to $A$. idonea than to any other.

Length, $51 \mathrm{~mm}$; height, $53 \mathrm{~mm}$.; diameter, $53 \mathrm{~mm}$.

Occurrence.-St. Mary's Fonmation. St. Mary's River, Crisfield well at depth of 140 feet (U. S. National Museum).

Collections.-Maryland Geological Survey, U. S. National Museum.

Section SCAPHARCA SS.

Arca (Scapharca) staminea Say.

Plate CV, Figs. 2, 3, 4, 5, 6.

Arce staminea Say, 1\$32, Amer. Conch., pl. xxxvi, fig. 2.

Ared elevata Conrad, 1840, Fossils of the Medial Tertiary, No. 1, 2a p. o1 cover. Area callipleura Conrad, 1840, Fossils of the Medial Tertiary, p. 54, pl. xxix, fig. 2. Area triquetre Conrad, 1843, Proc. Acad. Nat. Sci. Phila., vol. i, p. 305.

Area triquetru Conrad, 1845, Fossils of the Medial Tertiary, p. 59, pl. xxxi, fig. 2. Scapharet cullipleura Conrad, 1863, Proc. Acad. Nat. Sci. Phila., vol. xiv, p. 5 r9. Scapharee triquetra Conrad, 1863, Proc. Acad. Nat. Sci. Phila., vol. xiv, p. 580. Scapharca callipleura Meek, 1864, Miocene Check List, Smith. Misc. Coll. (183), p. 6. Scapharca triquetra Meek, 1864, Miocene Check List, Smith. Misc. Coll. (183), p. 6. Area (Scaplarca) callipleura Whitfield, 1894, Mon. xxiv, U. S. Geol. Survey, p. 43, pl. vi, figs. 8, 9 .

Scapharca (Scapharea) staminea Dall, 1898, Trans. Wagner Free Inst. Sci., rol, iii, pt. iv, p. 642. 
Description._ "Shell thick prominently convex; with ahout twentyeight ribs which are rounded and narrower than the intervening spaces. excepting on the anterior side. where ther are broader, and simply wrinkled, those of the anterior part of the disk have one or two longitudinal impressed lines; they are crossed by numerous transverse, elevated lines, which are hardly more distant from each other than their own width; intervening spaces wrinkled: Joaks distant, curved a little backward, and the tip a little behind the hinge margin: area flattened, a little curved, rather spacions, with obvious impressed, oblique lines: hinge margin rectilinear. with small, numerons teeth: posterior margin regularly arcuated: base subrectilinear, very deeply crenated: anterior margin oblique, rectilinear: anterior side abruptly compressed." Say, 1832 .

Shell very elevated and rentricose; umbonal and posterior slopes forming almost a right angle, near which the ribs are striated instead of granulated : basal margin regularly curved or in the more elongated specimens slightly incurved posteriorly.

A careful comparison of what are doubtless the type specimens of A. callipleura shows that it is hut a short, elevated, thickened and well sculptured form of 1 . staminea.

Length, $44 \mathrm{~mm}$; height. $38 \mathrm{~mm}$; diameter, $21 \mathrm{~mm}$.

Occurrence.-Choptank Formatios. Gorernor Run, 2 miles sonth of Governor Run, Flag Pond. Jones Wharf. Cuckold Creck. Turner. Dover Bridge, Peach Blossom Creek, Greensboro.

Collections.--Maryland Geologieal Survey, Johns Hopkins T'nirersity. U. S. National Mrsemm, Philadelphia Acarlemy of Tatural Siciences.

\section{Arca (Scapharca) arata Say.}

Plate CT. Figs. \%a, \%b.

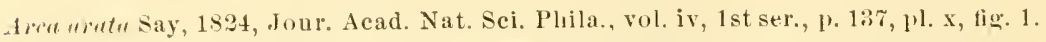
Ara aruta Courad, 1sti, Fossils of the Medial Tertiary, p. 58, pl. xxx, tig. f.

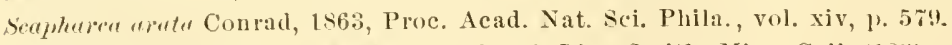
Sraphara "rofu Meek, 1864, Miocene Check List, Smith. Misc. Coll. (183), P. 6. Scupharea (Scepherea) worta Dall, 1898, Trans. Waguer Free Inst. Sci., rol. iii, pt. iv, 1. $6+$ s.

Description. - "Shell transversely oblong, subrhomboidal, with about twenty-six longitudinal ribs; basal edge nearly parallel to the hinge margin, which latter terminates anteriorly in an angle. 
"Ribs somewhat flattened, as wide or rather wider than the intervening spaces; the whole surface concentrically wrinkled: umbones not remarkably prominent: apices remote, the intervening space rhomboidal, with continned indented lines, arenated under the apices: hinge margin perfectly rectilinear, angulated at the extremities, the anterior one a little projecting: teeth with a contimned, minterrupted line, parallel, excepting at the two extremities of the line, which deeline a little, and the teeth are there decidedly longer and oblique with respect to the others of the range: posterior end obliquely rounded to the base: base nearly rectilinear and parallel to the hinge margin, and deeply crenated on the inner margin: anterior end produced below the middle, and rounded, and a little contracted near the superior angle." Say, 1824.

Length, $5.5 \mathrm{~mm}$.; height, $34 \mathrm{~mm}$. : diameter, $16 \mathrm{~mm}$.

Occurrence.-St. MarY's Forulation. St. Mary's River (quite rare).

Collections.-Maryland Geological Survey, U. S. National Museum.

Arca (Scapharca) idonea Conrad.

Plate CVI, Figs. 1, 2.

Area idmen Conrad, 1832, Fossil Shells of the Tertiary, 1. 16, jl. i, fig. 5.

A'a stillicidum Conrad, 1s32, Fossil Shells of the Tertiary, p. 15, pl. j, fig. 3 (young).

Lrece idomer Conrad, 1840, Fossils of the Media] Tertiary, p. 55, pl. xxix, tig. 3.

Arca stillicilum Conrad, 1840, Fossils of the Medial Tertiary, 1. 55.

Area idnuca Emmons, 185S, Rept. N. Car. Geol. Survey, 1. 285.

Lutiare illonea Con rad, 1\$62, Proc. Acad. Nat. Sci. Phila., vol, xiv, p. 28!.

Srrpherea idoner Conrad, 1863, Proc. Acad. Nat. Sei. Phila., vol. xiv, p. 579.

Sirrpheren idoner Meek, 186t, Miocene Check List, Smith. Misc. Coll. (183), p. 6.

Arere (Latierea?) irlonea? Whitfield, 1894, Mon. xxiv, U. S. Geol. Survey, p. 47, pl. vii, tig. 1.

Seaphacea (Scaphurea) idonea Dall, 1s9s, Trans. Wagner Free Inst. Sci., vol. iii, pt. iv, p. 639 .

Description.- " ${ }_{6}$ Cordate, inequivalve, rentricose, and slightly sinuous; ribs about 25 , narrow and erenulated; the crenulations most distinet on the larger valve; beaks very prominent and distant; area with undulated grooves; hinge with the series of teeth contracted in the center, and a little decurved at the ends." Conrad, 1832.

The shell is thick and large with a more or less sharply angular slope from the beak to the posterior extremity of the base. Near this angulation the ribs of both valves are finely striated. The more angular 
rariety resembles $A$. staminea, its probable progenitor. The ribs vary from twenty-five to thirty-one, twenty-eight or twenty-nine being quite common. The teeth are fine. narrow, close set and tend to become irregular at the anterior and posterior ends of the dental area.

Length, $68 \mathrm{~mm}$; height, $55 \mathrm{~mm}$.; diameter, $28 \mathrm{~mm}$.

Occurrence.-St. Mari's Formation. Cove Point, Langley's Bluff, St. Mary's River.

Collections.-Maryland Geological Survey, Johns Hopkins University, U. S. National Musem.

\author{
Subgenus NOËTIA Gray. \\ Arca (Nö̈tia) INCILE Say \\ Plate CVI, Figs. 3, 4 .
}

Area incile Say, 1824, Jour. Acad. Nat. Sei. Phila., vol. ir, 1 st ser., 1). 13!, pl, x, fig. 3. Area imile Contad, 1s32, Fossil shells of the Tertiary, 1. 16, pl. ii, tig. 1.

Arcu incile Courad, 1840 , Fussils of the Medial Tertiary, 11. 56, 11. xxix, tig. 5.

Aren incile Tuomey and Holmes, 1856, Pleiocene Fossils of Sonth Caroliua, 1. 35, pl. xiv, tigs, 6, 7, 18 .

Arcu incite Emmons, 1858, Rept. N. Car. Geol. Survey, 1. 2st.

Anomalorardia incile Conrad, 1863, Proc. Acad. Nat. Sci. Phila, rol. xir, 1). 5so.

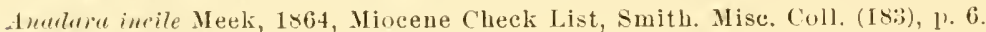

Noëtia protext, Comrad, 1875, Rept. N. Car. Geol. Survey, vol. i, apl). A, 1) 19, pl. iii, tig. 5 (fide Dall).

Arece (Noëtin) incile Dall, 189s, Trans. Wagner Free Inst. Sci, vol, iii, pt. ir, 1. ti3:.

Description.—." Shell transversely rhomboidal, with about twentyseven ribs; anterior hinge margin compressed and angulated.

"Dish: prominent from the beaks to the anterior part of the base: ribs with transverse granules; those anterior to the middle alternating with very slender and but little prominent lines, and with a groove on each: anterior margin longer to the base than the posterior end, and contracted in the middle: series of teeth nearly rectilinear, entire; interval between the teeth and the apices with a few transverse lines or wrinkles; a single oblique groove from the apex to a little before the middle, and six or seven narrow ones from the teeth outwards behind the apices: bealis placed rery far backward: inner margin crenated: muscular impressions a little elevated, posterior one short: basal margin not parallel with the hinge margin." Say, 18\%t. 
In Say's description above the two ends have been transposed, so that for anterior, posterior, before, behind, etc., read the opposite term. The very anterior position of the beak, the longer line of finer, narrower teeth and smaller size of the shell distinguish it from A. limula.

Length, $40 \mathrm{~mm}$.; height, $22 \mathrm{~mm}$.; diameter, $11 \mathrm{~mm}$.

Occurrence.-Choptank Formation. Jones Wharf, Dover Bridge (rare and small).

Collection.-U. S. National Mruseum.

Subgenus BARBATIA (Gray) Adams.

Section STRIARCA Conrad.

Arca (Barbatia) centenaria Say.

Plate CVI, Figs. 5, 6.

Arca centenaria Say, 1824, Jour. Acad. Nat. Sci. Phila., vol. iv, 1st ser., p. 138, pl. $x$, fig. 2.

Arca centenaria Conrad, 1832, Fossil shells of the Tertiary, p. 16, pl. i, fig. 4 .

Arca centenaria Conrad, 1840, Fossils of the Medial Tertiary, p. 55, pl. xxix, fig. 4. Arca centenaria Tuomey and Holmes, 1856. Pleiocene Fossils of South Carolina, p. $3 \pi$, pl. xiv, figs. 11,12 .

Area centenuria Emmons, 1858, Rept. N. Car. Geol. Survey, 1. 285, fig. 205.

Striurea centenuria Conrad, 1863, Proc. Acad. Nat. Sci. Plila., vol. xiv, p. 580.

Striarca centenuria Meek, 1\$64, Miocene Check List, Smith. Misc. Coll. (183), p. 6.

Area (Striarea) ecntenariu Whitfield, 1894, Mon. xxiv, U. S. Geol. Survey, p. 42, pl. vi, figs. 5- 5 .

Barbatic (Striarea) centenaria Dall, 1898, Trans. Wagner Free Inst. Sci., vol. iii, pt. iv, p. 62S.

Description.- "Shell transversely-oval, subrhomboidal, obtusely contracted at base, with numerous alternate longitudinal striæ.

"Striæ from one hundred to one hundred and eighty and more in number; disappearing on the hinge margin; with hardly obvious transverse minute wrinkles, and larger, remote, irregular ones of increment; beaks but little prominent, not remote; base widely but not deeply contracted, nearly parallel with the hinge margin; anterior and posterior margins obtusely rounded; series of teeth rectilinear, uninterrupted, decurved at the tips; space between the beaks with numerous grooves proceeding from the teeth; inner margin not very distinctly crenated; muscular impressions elevated, and forming a broad line each side, from the cavity of the beak to the margin." Say, 1824. 
Length, $20 \mathrm{~mm}$; height, $12 \mathrm{~mm}$; diameter, $6 \mathrm{~mm}$.

The Tirginia specimens are often twice these dimensions or larger.

Occurence.-Сhoptank Formation. Jones Wharf. Rare and small. Calvert Fordatiox. Chmeh Hill, Fairhaven.

Collection.-Maryland Geological Survey.

Section CALLOARCA Gray.

Arca (Barbatia) marylandica Conrad.

Plate CVI, Fig. \%.

Byssoure marylumien Conrad, 1840, Fossils of the Medial Tertiary, p. 54, pl. xxix, fig. 1.

Barbatir Marylamdirn Conrad, 1863, Proc. Acad. Nat. Sci. Phila., vol. xiv, p. 580.

Burbatir marylumdiru Meek, 1864, Miocene Check List, Smith. Misc. Coll. (183), 1. 6.

Berbutiu Murylandice Whitfield, 1894, Mon. Xxiv, U. S. Geol. Survey, 1. 48, pl. vii, tigs. 2-4.

Burbatia (Callourea) marylundien Dall, 1898, Trans. Wagner Free Inst. Sci., rol. iii, pt. iv, p. 623 .

Description.- "Shell oblong, compressed, thin, with very numerous radiating granulated striæ: beaks not prominent; base much contracted or emarginate anterior to the middle; posterior side dilated, the superior margin very oblique and emarginate; extremity angulated, and situated nearer to the line of the hinge than to that of the base; cardinal teeth minute, except toward the extremities of the cardinal line where they are comparatively very large and oblique; imner margin entire." Conrad, $18+0$.

It may be readily identified by its gencral shape, or when found in fragments, as is usually the case, by the granulations of the strix.

Length, $30 \mathrm{~mm}$; height, $2 \% \mathrm{~mm}$.

Occurrence.-Calvert Foratation. "Cliffs of Calvert" (Conrad), 3 miles west of Centerville. Plum Point, Centerville.

Collections.-Maryland Geological Survey, U. S. National Museum.

Section GRANOARCA Conrad.

Arca (Bafbatia) virginia Wagner.

Plate CVI, Fig. S.

Arer virginice Wagner, 1839 ?-See Dall, below.

Area rirginice Bronn, 1848, Hand. Gesch. Nat., Index Pal., pt. i, p. 99.

Area virginit. Bronn, 1849, Hand. Gesch. Nat., Index Pal., pt. ii, p. 283. 
Arca virginice Dall, 1898, Trans. Wagner Free Inst. Sci., vol. v, pt. ii, p. 9, pl. i, fig. 3.

Berbatia (Granource) virginice Dall, 1898, Trans. Wagner Free Inst. Sci., vol. iii, p. 62i, pl. xxxii, fig. 23.

Description.-." Arca virginia is a large, solid, elongated shell, equivalve but very inequilateral, the beaks being situated near the anterior fifth of the length, low and prosogrrate, distant and separated by a wide cardinal area with numerous (nine) slightly angular longitudinal concentric grooves; sculpture of about twenty-five strong radial ribs, smaller on the yosterior dorsal area, somewhat flattened, and on the posterior part with a shallow, wide mesial furrow, hinge line $\frac{11}{17}$ as long as the shell; tecth vertical, in two series, begiming mesially very small, distally larger, and with a tendeney to break up or become irregular; musular impressions deep; margin fluted in harmony with the ends of the ribs. ..." Dall, op. cit., vol. iii, p. 628 .

Two imperfect and mmeh worn shells from the St. Mary's River, ts and $34 \mathrm{~mm}$. in length, respectively, probably helong to this species.

Length, $83 \mathrm{~mm}$. height, $52 \mathrm{~mm}$; diameter, $42 \mathrm{~mm}$.

Occurrence.-St. Marr's Formation. St. Mary's River.

Collections.-Maryland Geological Survey, Wagner Free Institute of Science.

\section{Subfamily PECTUNCULIN $Æ$. Genus GLYCYMERIS Da Costis. \\ Glicymeris parilis (Conrad).}

Plate CVII, Figs. 1, 2.

Pectunculus lentiformis Conrad, 184\%, Proc. Nat. Inst., Bull, ii, pp. 181, 183 (listed only).

Not Pectunculus lentiformis Conrad, 1837, Fossil Shells of the Tertiary, 3nd. Edit., p. 36.

Pectunculus purilis Con rad, 1843, Proc. Acad. Nat. Sci. Phila., vol. i, 1. 306.

Pectunculus purilis Conrad, 1845, Fossils of the Medial Tertiary, p. 64, pl. xxxvi, fig. 2.

Pectuneulus perilis Conrad, 1868, Proc. Acad. Nat. Sci. Phila., vol. xiv, p. 580.

Pectunculıs purilis Meek, 1864, Miocene Check List, Smith. Misc. Coll. (183), p. 5.

Glycymeris parilis Dall, 1898, Trans. Wagner Free Inst. Sci., vol. iii, pt. iv, p. 609.

Description._- Orbieular, slightly oblicue; height and length equal; posterior superior margin obliquely subtruncated; ribs defined by slightly 
impressed narrow radii; radiating striæ minute and obsolete; marginal teeth prominent." Conrad, 1843.

This is the common species of the Calvert formation. Conrad has caused some confusion by listing in 1842, as P. lentiformis, some specimens from the Calvert formation at Hance's and Wilkinson's, that must have been the then undiscriminated $P$. parilis. I know of no true $P$. lentiformis specimens that have been found in Maryland.

Height, $90 \mathrm{~mm}$.; width, $88 \mathrm{~mm}$; diameter, $23 \mathrm{~mm}$.

Occurrence.-St. Mary's Formation. St. Mary's River (Dall). CaLvert Formation. Chesapeake Beach, 3 miles south of Chesapeake Beach, Plum Point, Truman's Wharf, Church Hill, Wye Mills, Reed's, 'Tilghman's Station, Skipton (Dall).

The St. Mary's River reference is probably a mistake. No one else has listed it from there. Careful search has failed to find it there, and no specimens from St. Mary's River could be found in the National Museum.

Collections.-Maryland Geological Survey. Johns Hopkins University, Philadelphia Academy of Natural Sciences, U. S. National Mruseum, Comell University.

\section{Glicyimeris subovata (Say).}

Plate CVII, Figs. 3, 4.

Pectuneulus xubmutus Say, 1824, Jour. Acad. Nat. Sci. Phila., vol. iv, 1st ser., p. 140, 1.I. x, tig. 4.

Pectuneulus suboutus Conrad, 183:, Fossil shells of the Tertiary, p. $1 \%$, pl. x, fig. 3.

Pectunculus suboratns Conrad, 1845, Fossils of the Medial Tertiary, 1. 62, pl. xxxiv, tig. 1.

P'ectmeculus. suboutues Emmons, 185s, Rept. x. Car. Geol. Surrey, p. 286, tig. 207.

Pectuneturs sethemetus Conrad, 1A63, Proe. Aead. Nat. Sci. Plila., vol. xir, p. 581.

Pectunemlus subovetus Meek, 1S65, Mineene Check List, Smith. Mise. Coll. (1s3), p. 5.

Glycimeris smbovete Dall, Is!s, Trans. Wagner Free Inst. Sei., vol. iii, pt. iv, p. 611.

Description.-." Longitudinally short ovate, with about thirty longitudinal impressed acute lines, the intervals a little convex.

"Shell increasing in width by a slightly curved line from the apex to beyond the middle: lateral curvatures equal: apices separate, small, central; intervening space with but little obliquity to the plane of the shell, with obsolete angulated lines: teeth forming a regularly and much 
arcuated series, which is rectilinearly truncated above so as to leave in that part a mere edentulous elevated line: within destitute of striæ: margin with elevated angular lines: exterior surface with about thirty longitudinal, impressed, acute lines, the intervals a little convex." Say, 1824.

The specimens in the Philadelphia Acadeny of Natural Sciences labelled "Md." are similar in color to ones from the Yorktown, Va., region and have material between the teeth and in some holes in the shell very suggestive of the same locality. I very much doubt their having come from Maryland.

Height, $33 \mathrm{~mm}$. : width, $36 \mathrm{~mm}$. ; diameter, $11 \mathrm{~mm}$. This is less than usual size as found in Virginia and elsewhere.

Occurrence.-Choptank Formation. Greensboro, Davis's Mill on Choptank, near Skipton.

Collections.-Maryland Geological Survey, U. S. National Museum.

\section{Superfamily NUCULACEA. \\ Family LEDID $Æ$.}

Genus LEDA Schumacher.

LEDA LICIATA (Conrad).

Plate CVII, Figs. 5, 6, \%, 8.

Vuenlu liciutu Conrad, 1843, Proc. Acad. Nat. Sei. Pbila., vol. i, 1) 305.

Sumla liciutu Conrad, 1845, Fossils of the Medial Tertiary, p. 64, pl. xxxvi, fig. 3.

Nucule liciete Conrad, 1863, Proc. Acad. Nat. Sci. Phila., vol. xiv, p. 581.

Nucula liriutu Meek, 1864 , Miocene Check List, Smith Misc. Coll. (183), 1'. 5.

Lede. acrybie Dall, 1s98, Trans. Wagner Free Inst. Sci., vol. ii, pt. iv, p. 590.

Ledu phalacra Dall, 1898, Traus. Wagner Free Inst. Sci., vol, iii, pt. iv, p. 592.

Description.- "Ovate-acute, rentricose, with about fifteen concentric lamelliform strix; posterior side much shorter than the anterior; anterior side slightly recurved, with an oblique slight submarginal furrow, causing a slight emargination of the base near the extremity." Conrad, 1843.

The above is Conrad's original description. His specimens are in the Philadelphia Academy of Natural Sciences. A study of abundant material shows that the concentric strix vary from fifteen, or fewer, to wellnigh thirty, becoming at the same time finer and more indistinct over 
the umboual slope and partially or entirely obsolete near the margin. In other specimens a larger and larger portion of the surface in this way becomes smooth, until they finally grade over into perfectly smooth polished forms. One having but a few valves belonging to different portions of the series would naturally consider them distinct species.

Leda acrybia is a typical L. Ticiata and stands at one end of the series. L. phatacra is one of the intermediate forms with the strix partially obsolete, while $L$. amydra is the smooth, polished variety forming the other end member of the series. It has not been practicable to separate the intermediate forms from the liciata. They are accordingly grouped together, while the smooth polished end member, L. amydra, has been retained as a variety.

Length, 10.) mm.; height, $6.1 \mathrm{~mm}$. : diameter, 2.5 $\mathrm{mm}$.

Occurrence.-Choptank Formation. Greensboro. Calvent Formation. Chesapeake Beach, 3 miles south of Chesapeake Beach, Plmm Point, 'Truman's Wharf.

Collections.-Maryland Geological Survey, Johns Hopkins University, U. S. National Museum, Philadelphia Academy of Natural Sciences.

\section{LEDA LICTATA VAR. AMYDRA Dall.}

Plate C'TII, Figs. 9, 10.

Lede amydra Dall, 1898, Trans. Wagner Free Inst. Sci., vol, ii, ft. iv, 11, 591, 592.

Description._."Shell sinall, smooth, polished, subequilateral, moderately convex, with an evenly areuate base, no lumule, and the escuteheon small, narrow, excavated, bounded outside by a raised line beyond which is a second furrow extending nearly to the end of the rostrum; the chondrophore is small and deep-seated with about a dozen small teeth on each side of it: the rostrmm is short, rounder, and without any internal partition... .

"This shell is remarkably like a small Leda from the Claiborne sands which I have without a name, but is more rounded behind. More material is needed to establish its exact relations." Dall, 1898.

Dr. Dall's description was from a single valve found at Plum Point. It is but a variety of $L$. liciata and distinguished from the other members of the series of which it is an end member, by its smooth. polished surface. 
Length, $11.5 \mathrm{~mm}$; height, $6 \mathrm{~mm}$. ; diameter, $2.3 \mathrm{~mm}$.

Occurrence.-Calvert Formation. Plum Point.

Collections.-Maryland Geological Survey, Johns Hopkins University, U. S. National Musenm.

\section{LedA CONCENTRica (Say).}

Plate CVIII, Figs. 1, 2.

Tucule rourentricu Say, 1824, Jour. Acad. Nat. Phila., vol. iv, 1st ser., p. 141.

Nucula roncentriar Saly, 1831, Amer. Conch., pl. xii.

Nurela conecutrira Conrad, 1845, Fossils of the Medial Tertiary, 1. 57, pl. xxx, fig. 3. Sucula eborea Conrad, 1846, Proc. Acad. Nat. Sci. Pliliı, vol. iii, 1. 24, pl. i, fig. 4.

Not Foldia eboren Conrad, 1860, Jour. Acad. Nat. Sci. Phila,, and ser., vol. ir, p. 295, pl. xlvii, tig. 26; nor Conrad, 1863, Proc. Acad. Nat. Sci. Phila, vol. xiv, 1. 5s1; nor Meek, 1864, Miocene Cleck List, Smith. Mise. Coll. (183), p. 5. Tueule ronentrier Conrad, 1s6:, Proc. Acad. Nat. Sci. Phila., vol. xiv, p. 581.

Nucula momertrica Meek, 1864, Miocene Clseck List, Smitl. Misc. Coll. (1 83), 1) 5.

Ledu concentrica Dall, 1898, Trans. Wagner Free Inst. Sci, vol. ii, pt. iv, p. 588.

Description._-"Transversely elongate-subovate, rostrated, concentrically striated.

"Shell convex; rostrum considerably narrowed towards the tip: surface concentrically striated with numerous, regular, equidistant, rounded lines: bealis rather behind the midtle: ligament margin a little concave: series of teeth angulated at the beaks...

"The regularly striated surface gives this shell a very pretty appearance. In outline it has some resemblance to the rostrata." Say, $18 \% t$. Length, $6 \mathrm{~mm}$; height, $4 \mathrm{~mm}$; diameter, $1.1 \mathrm{~mm}$.

Occurrence.-ST. Mary's Formatiox. St. Mary's County (Say); Pocomoke City at a depth of 53 to $\% 5$ feet in a well boring where it may be later than Miocene.

Collections.-Maryland Geological Survey, Johns Hopkins University. Wagner Free Institute of Science.

Genus YOLDIA Moller.

Yoldia Levis (Say).

Plate CVIII, Figs. 3, 4.

Necule levis Say, 1824, Jour. Acad. Nat. Sci. Phila., vol. iv, 1st ser., p. 141, pl. x, tig. 5.

Necule levis Say, 1831, Amer. Conch., pl. xii. 
Nucula limatula Conrad, 1845, Fossils of the Medial Tertiary, pp. 57, 55, pl. xxx, fig. 4 .

Nucula timatula Tuomey and Holmes, 1856. Pleiocene Fossils of South Caroliua, p. 52, pl. xvii, figs. 13-15 (not of say).

Foldia levis Conrad, 1863, Proc. Acad. Nat. Sci. Phila., vol. xiv, p. 581.

Yoldir lavis Meek, 1864, Miocene Check List, Smith. Mise. Coll. (183), p. 5.

Soldia levis Dall, 1898, Trans. Wagner Free Inst. Sci., vol. ii, pt. iv, p. 596.

Description.- "Transversely elongate-subovate, rostrated, nearly smooth.

"Shell compressed, thin, fragile, polished, smooth, slightly wrinkled toward the base; beaks nearly central, hardly prominent beyoud the hinge margin, rounded, approximate; series of teeth subrectilinear, a little arcuated behind; teeth prominent; hinge margin exteriorly both before and behind the beaks rather abruptly compressed; posterior margin rounded; anterior margin somewhat rostrated, the anterior hinge margin rectilinear, very little reflected at tip ; inner margin simple." Say, 1824.

This species has often been confused with the Pleistocene and Recent $Y$. limatula, of which it is doubtless the ancestor. "It differs from the latter by its proportionally larger chondrophores, smaller and more numerous teeth, somewhat more pointed posterior end and less compressed escutcheon." Dall.

Casts from three miles north of Plum Point reach a very large size, being $5 \mathrm{~cm}$. in length and $2 \mathrm{~cm}$. in height. Specimens from other places are a half to a third these dimensions.

Occurrence.-St. Mary's Formation. Cove Point, St. Mary's River, Langley's Bluff. Choptaxk Formatiox. Jones Wharf, Sand Hill. Calvert Formation. Church Hill. Fairhaven, Parker Creek, 3 miles north of Plum Point, Lyon's Creek, White's Landing.

Collections.-Maryland Geological Survey, Johns Hopkins University, U. S. National Museum.

\author{
Family NUCULIDÆ. \\ Genus NUCULA Lamarck. \\ Nucula proxima Say. \\ Plate CVIII, Figs. 5, 6.
}

Nucula obliqua Say, 18:0, Amer. Jour. Sci., vol. ii, p. 40; not of Lamarck, 1819. Nucula proxime Sily, 182:, Jour. Acad. Nat. Sci. Phila, vol. ii, 1st ser., p. 2ro 
Nucula proxima Tuomey and Holmes, 1856, Pleiocene Fossils of South Carolina, p. 53, pl. xvii, figs. 7-9.

Nucula proxima Emmons, 185s, Rept. N. Car. Geol. Survey, p. 287, fig. $208 \mathrm{~B}$.

Nucula proxama Dall, 1889, Bull. xxxvii, C. S. Nat. Mus., p. 42, pl. lvi, fig. 4.

Nucula proxima Whitfield, 1894, Mon. xxiv, U. S. Geol. Survey, p. 50, pl. vii, figs. i-10.

Nucula proxima Dall, 1898, Trans. Wagner Free Inst. Sci., vol. iii, pt. iv, p. 574.

Description.- "Shell subtriangular, oblique, concentrically wrinkled, and longitudinally marked with numerous, hardly perceptible striæ; posterior margin very short and very obtusely rounded, a submarginal impressed line; anterior margin very oblique and but slightly arcuated; umbo placed far back; within perlaceous, polished, edge strongly crenated; teeth of the hinge robust, the posterior series very distinct and regular.

"Very much resembles $N$. nucleus, but is proportionally wider, and the posterior series of teeth is more regular and distinct. It may possibly prove to be only a variety, when numerous specimens are carefully examined and compared." Say, 1822.

Those from Church Hill are much larger than those from the other localities given below, the measurements being: length, $12 \mathrm{~mm}$; height, $10.5 \mathrm{~mm}$.; diameter, $4 \mathrm{~mm}$.; and length, $6.5 \mathrm{~mm}$.; height, $5.3 \mathrm{~mm}$.; diameter, $2.1 \mathrm{~mm}$., respectively.

Occurrence.-Сhoptank Formation. Dover Bridge, Cordova. CaLvert Formation. Church Hill, 3 miles west of Centerville, Fairhaven, 3 miles south of Chesapeake Beach, Plum Point, Truman's Wharf.

Collections.-Maryland Geological Survey, Johns Hopkins University, U. S. National Nuseum.

\section{Nucula sinaria Dall.}

Plate CVIII, Figs. $\%, 8$.

Vucula sinaria Dall, 1898, Trans. Wagner Free Inst. Sci., vol. iii, pt. iv, p. 575, pl. xxxii, fig. $\%$.

Description.- "Shell small, solid, trigonal, polished, with fine, radial striæ, more distinct near the basal margins, and faint, concentric, rather irregular furrows, obsolete over most of the valve, but tending to be stronger near the anterior and posterior slopes; here and there one crosses the whole shell like the indication of a resting stage; dorsal slopes nearly straight, base arcuate, ends rounded; lunule absent, escutch- 
eons impressed; striated, the margins not pouting in the middle; beaks prominent, obtuse; interior brilliantly pearly, muscular impressions deep; the basal margins finely crenulate; hinge strong, wide; the chondrophore oblique, heary: anterior teeth wide, strong, about seventeen, posterior about seven....

"This species differs from the preceding [ $N$. chipolana] by its more trigonal, heary, and pearly shell, its wider and proportionately heavier hinge, and its impressed instead of merely flattened escutcheon. The Maryland specimens are usually larger and more worn than the types from West Florida; both retain a purplish tint in their nacre." Dall, 1898 .

Length, $4.75 \mathrm{~mm}$; height, $4 \mathrm{~mm}$; diameter, $2.5 \mathrm{~mm}$. (Dall).

Occurrence.-St. Mary's Formation. Cove Point, Langley's Bluff, St. Mary's River. Choptink Formation. Jones Wharf.

Collections.-Maryland Geological Survey, Johns Hopkins University, U. S. National Museum.

Nécla tapiria Dall.

Plate CVIII, Figs. 9, 10, 11.

Nucule tuphria Dahl, 1898, Trans. Wagner Free Inst. Sci., vol. iii, pt. iv, p. 576, pl. xxxii, tig. 14.

Description._ "Shell small, very solid, rounded cmeiform, with few strong, distant concentric groores, like marks of resting stages, which extend clear over the shell, otherwise snooth; beaks prominent, turgid; lunule absent; escutcheon faintly indicated; posterior end subtruncate, anterior produced and rounded, base moderately arcuate; interior hardly nacreous, muscular impressions large and distinct; basal margins entire; hinge strong and heary; chondrophore widle. distinct, a little oblique: anterior teeth thirteen, posterior six or seven. . .

"This interesting species is related to the recent $N$. delphinodonta Mighels, which is a more rounded and less oblique shell, withont the strong concentric grooves of $N$. taphria." Dall, 1898.

Length, $2.9 \mathrm{~mm}$; ; height, $2.25 \mathrm{~mm}$. ; diameter, $1.5 \mathrm{~mm}$. (Dall).

Occurrence.-St. Mari's Formation. St. Mary's River. Choptaxk Formation. Tones Wharf.

Collections.-Maryland Geological Survey, Johns Hopkins Tniversity, U. S. National Mruseum. 
Nugula prunicola Dall.

\section{Plate CVIII, Figs. 12, 13, 14.}

Nucula prunicola Dall, 1898, Trans. Wagner Free Inst. Sci., vol. iii, pt. iv, p. 5r6, pl. xxxii fig. 9.

Description.-." Shell small, inflated, polished, very inequilateral; surface with obsolete, obscure radial striæ, strong where they cross between the concentric ridges and near the ventral margin; beaks, dorsal slopes, escutcheon, and the posterior two-thirds of the sides of the shell smooth or nearly so; on the anterior third sculpture of moderately elevated concentric lamellæ separated by wider radially grooved interspaces; these lamellæ break off abruptly anteriorly, and posteriorly become gradually obsolete in front of the middle of the shell; they are strongest in front and near the margin; lunular area lanceolate, large, not impressed, marked by the cessation of the lamellæ; escutcheon roundly cordate, impressed; the margins pouting in the middle; there is no circumscribing line; beaks turgid, recurved; interior brilliantly pearly, the basal margin strongly crenulate, the muscular impressions feeble; base arcuate, ends rounded; chondrophore narrow, not prominent, anteriorly directed; the anterior line of teeth long, slightly arched, the posterior meeting it at nearly a right angle, short, straight; anterior teeth about twenty; posterior six or seven. ..." Dall, 1898.

This species may be readily distinguished by the concentric ridges or raised lamellæ on the anterior third of the shell.

Length, $6 \mathrm{~mm}$.; height, $4.5 \mathrm{~mm}$. ; diameter, $3.8 \mathrm{~mm}$.

Occurrence.-Calvert Formatios. Chesapeake Beach, 3 miles south of Chesapeake Beach, Plum Point.

Collections.-Maryland Geological Survey. Johns Hopkins University, U. S. National Museum. 
. 


\section{LIFE}

Leonidas Chalmers Glemn was born at Crowder's Creek, Torth Carolina, september 9, 18:1, and received his early training and preparation for college in the public and private schools of the county. Ifter spending a portion of a rear each in Clinton College, South Carolina, and Rutherford College, North Carolina, he entered the University of Sonth Carolina in 1888, where he received the degree of A. P. in 1891. The next fire years were spent in teaching. the summer of 189.5 being spent in physiographic work under Professor II. M. Davis at Harvard Iniversity. In the fall of 1896 he entered Johns Hopkins Tniversity. The summer of 189 r was spent in the eastern Kentucky coal fields on the United States Geological Survey, and the summer of 1898 and part of that of 1899 working on the Miocene areas of Maryland for the Maryland Geological surver, while other spare time was deroted to work for the North Carolina Geological survey. During the first year at Johns Hopkins he held an ordinary, and dnring the second an honorary scholarship from North Carolina. while rluring the third rear he was Fellow in Geology. 


\section{PLATE LXV.}

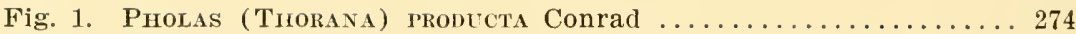

1. Exterior of left valve. South Carolina. (After Tuomey and Holmes.)

Figs. 2, 3. Bariea (Scobina) arcuata (Conrad)

2. Exterior of right valve. St. Mary's River.

3. Exterior of right valve. Same locality.

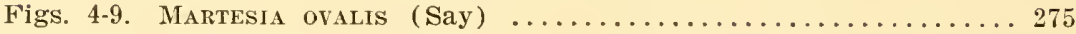

4. Exterior of right valve and broken protoplax. Drum Point. U. S. National Museum. (After Dall.)

5. Exterior of left valve and protoplax. Jones Wharf.

6. Exterior of right valve. Same locality.

7. Interior of left valve. Same locality.

8. Dorsal view showing gaping anterior and umbonal region projecting from enveloping tube.

9. Interior view of protoplax. Same locality.

Fig. 10. Panopea whitfieldi Dall

10. Exterior of right valve. Plum Point. 

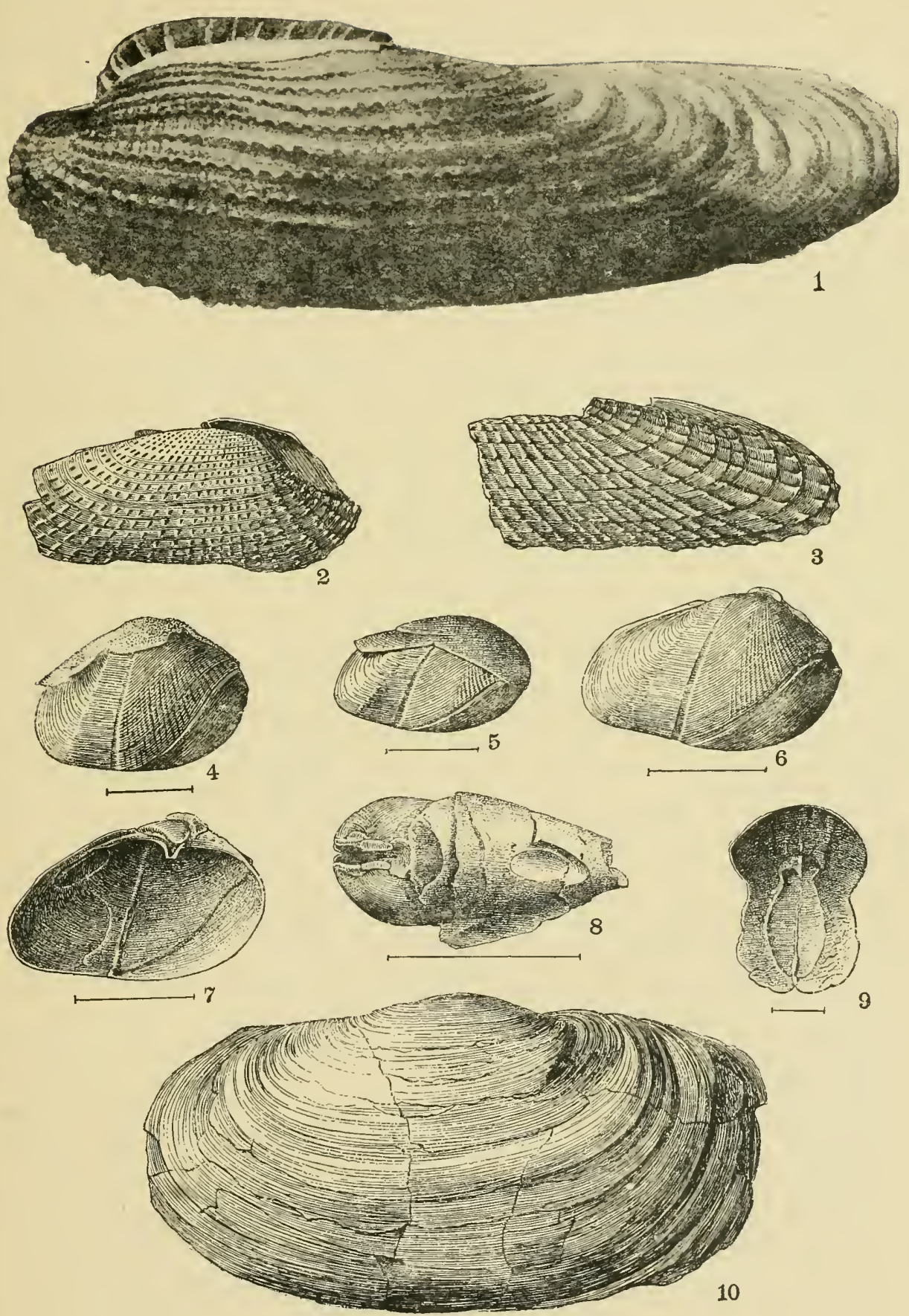


\section{PLATE LXVI.}

Fig. 1. Panopea goldfussir Wagner....................... 277

1. Exterior of right valve. Plum Point.

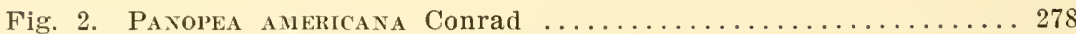

2. Exterior of left valve. Plum Point.

Figs. $3-6$. Saxicava arctica (Linné) $\ldots \ldots \ldots \ldots \ldots \ldots \ldots \ldots \ldots \ldots \ldots \ldots \ldots$

3. Exterior of left valve. Plum Point.

4. Exterior of right valve. Jones Wharf.

5. Interior of left valve. Jones Wharf.

6. Exterior of right valve of one of numerous distorted forms. Chesapeake Beach. 

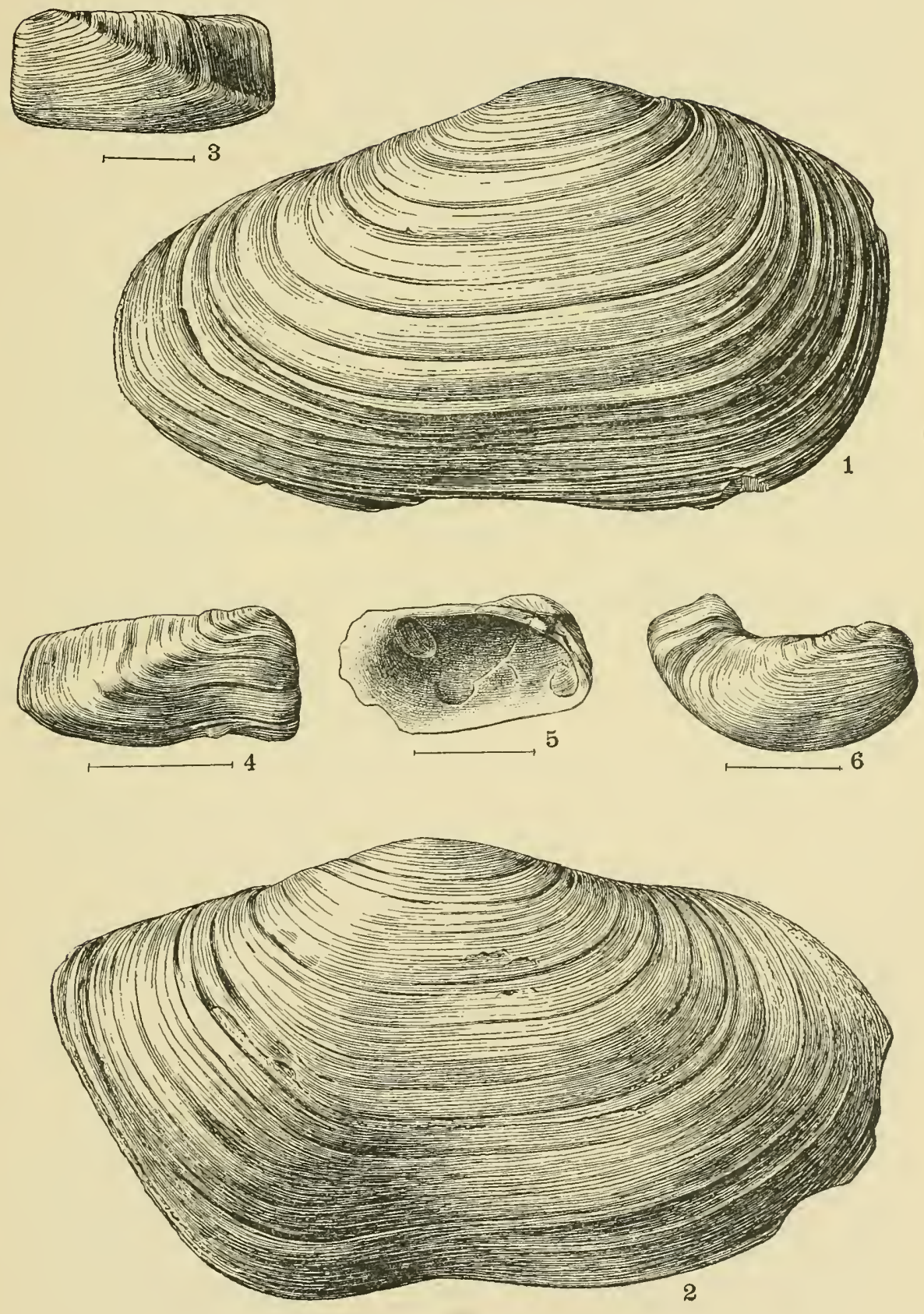

MOLLUSCA - PELECYPODA. 
PLATE LXVII.

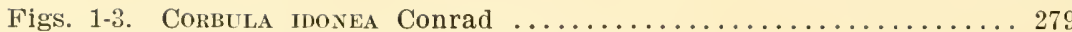

1. Exterior of right valve. Jones Wharf.

2. Interior of right valve of another specimen. Same locality.

3. Interior of left valve. Same locality.

Figs. 4-5. Corbula elevata Conrad

4. Interior of right valve. Plum Point.

5. Exterior of right valve. Same locality.

Figs. 6-14. Conbula in.equalis Say

6. Exterior of right valve. Church Hill.

7. Interior of right valve. Plum Point.

8. Exterior of right valve of large variety. St. Mary's River.

9. Exterior of valve. Jones Wharf.

10. Exterior of left valve. Church Hill.

11. Interior of left valve of coarsely sculptured variety. Plum Point.

12. Exterior of right valve of same individual as shown in Fig. 11.

13. Exterior of left valve. Jones Wharf.

14. Exterior of right valve. Oligocene of Oak Grove, Fla. Type specimen of $C$. whitfieldi Dall. (After Dall.)

Figs. 15-19. Corbula cuneata Say

15. Interior of left valve. Jones Wharf.

16. Exterior of left valve. Same locality.

17. Exterior of right valve. Same locality.

18. Exterior of right valve. Same locality.

19. Interior of right valve. Same locality. 


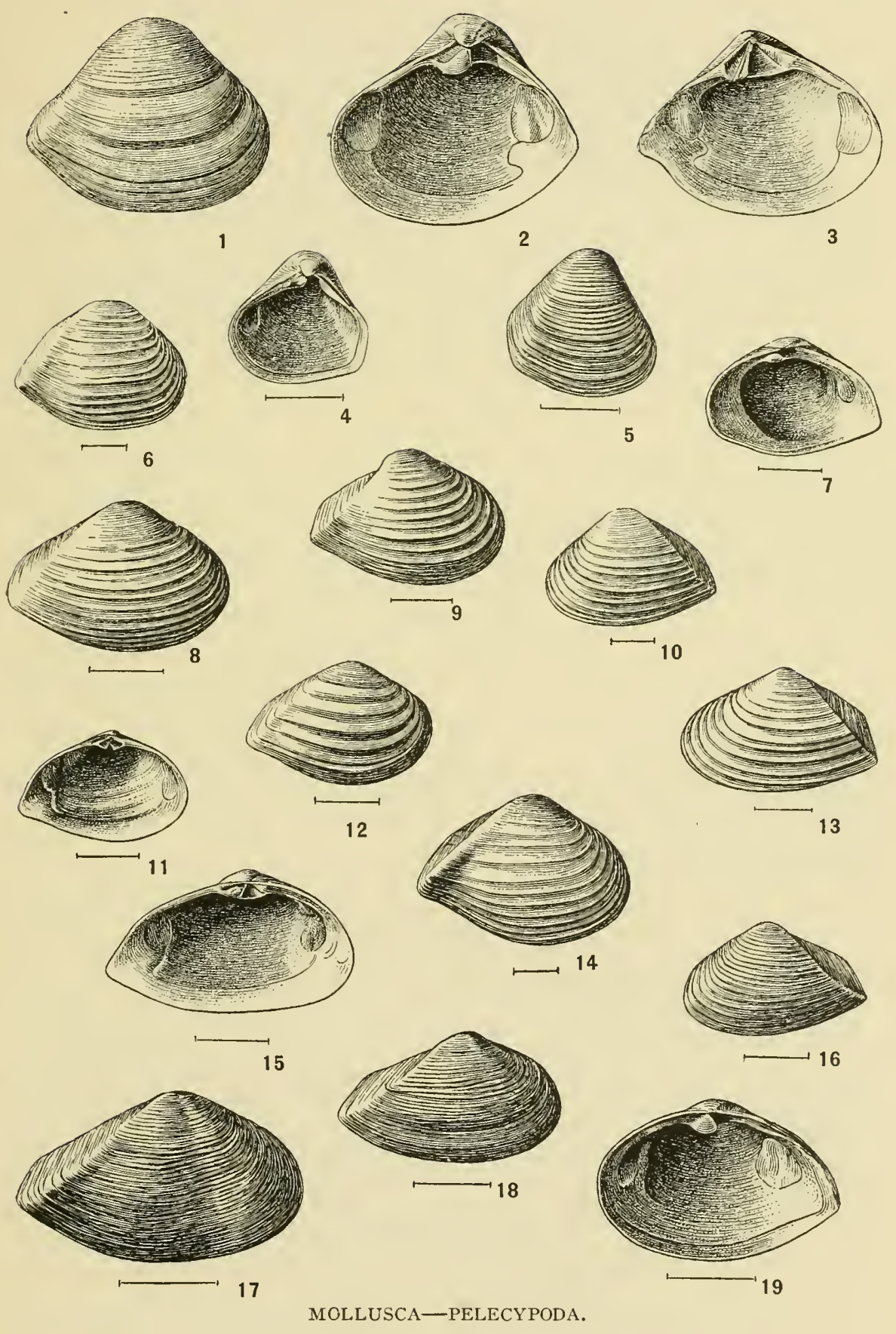




\section{PLATE LXVIII.}

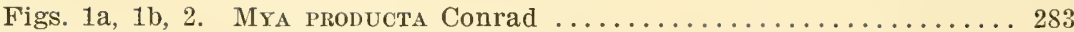

1a. Interior of left valve. Jones Wharf.

1b. Exterior of same valve.

2. Profile of hinge area of same valve.

Figs. 3-6. Sphenia dubia (H. C. Lea) .

3. Exterior of left valve. Jones Wharf.

4. Exterior of right valve. Jones Wharf.

5. Interior of left valve, large specimen. Jones Wharf.

6. Exterior of right valve, same individual as Fig. 5 .

Figs. 7, 8. Paramya subovata Conrad

7. Interior of left valve. Two miles south of Governor Run.

8. Exterior broken valve. Jones Wharf. 

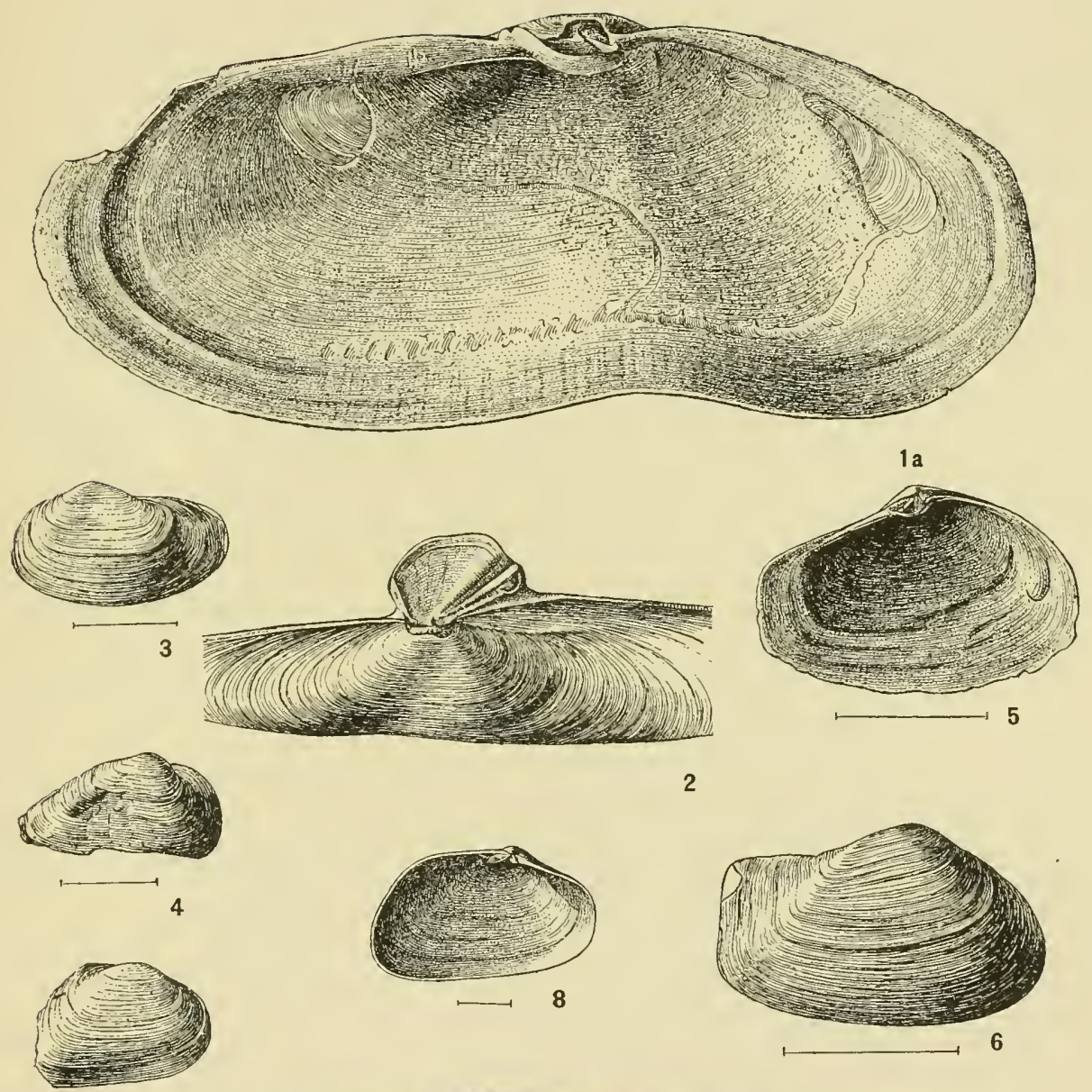

2

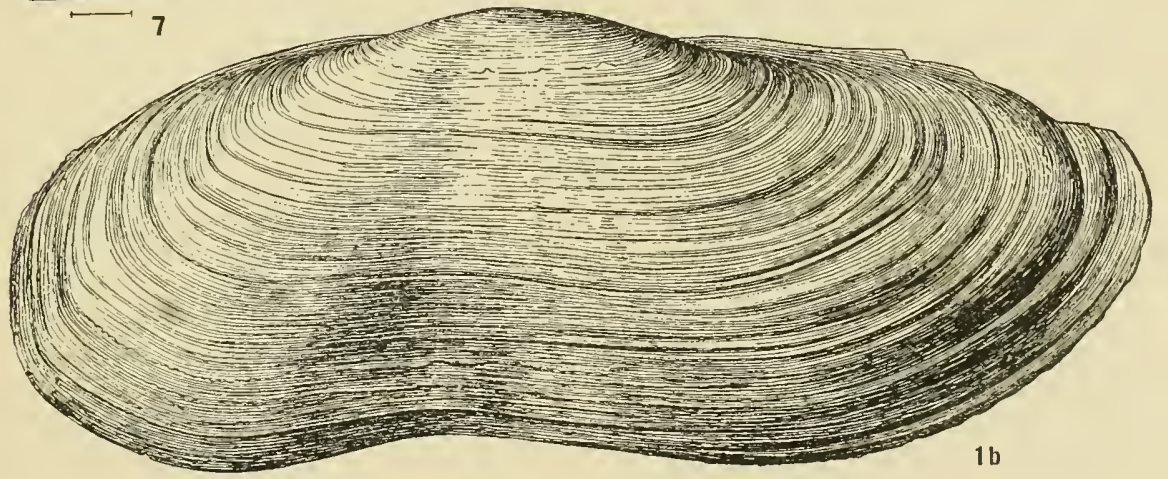

MOLLUSCA-PELECYPODA. 


\section{PLATE LXIX.}

Figs. 1-3. Mesodesma mariana n. sp

1. Exterior of right valve. Cove Point.

2. Interior of right valve. Same locality.

3. Interior of left valve. Same locality.

Figs. 4-6. Ervilia planata Dall

4. Interior of left valve. Church Hill.

5. Interior of right valve. Same locality.

6. Exterior of left valve. Same locality.

Figs. 7-9. Mactra clathrodon Lea 286

7. Interior of left valve. Cove Point.

8. Exterior of left valve. Same locality.

9. Interior of right valve. Same locality.

Fig. 10. Spisula (Hemmactra) delumis (Conrad) .............. 286

10. Interior of right valve. Suffolk, Va. $96 \mathrm{~mm}$. (After Dall.) $\times 5 / 6$

Fig. 11. Spisula (Hemimactra) marylandica Dall

11. Interior of right valve. $92 \mathrm{~mm}$. (After Dall.) $\times 3 / 4$

Figs. 12, 13. Spisula (Hemimactra) curtidens Dall............. 288

12. Outline of young shell traced from incremental lines on broken larger valve. $35 \mathrm{~mm}$. (After Dall.) $\times 5 / 6$

13. Hinge-plate of right valve: $a$, dorsal and $e$, ventral anterior laminae; $b$, anterior arm of cardinal tooth; $c$, ligament scar, without septum below it; $d$ and $f$, posterior laminae. $44 \mathrm{~mm}$. (After Dall.) 

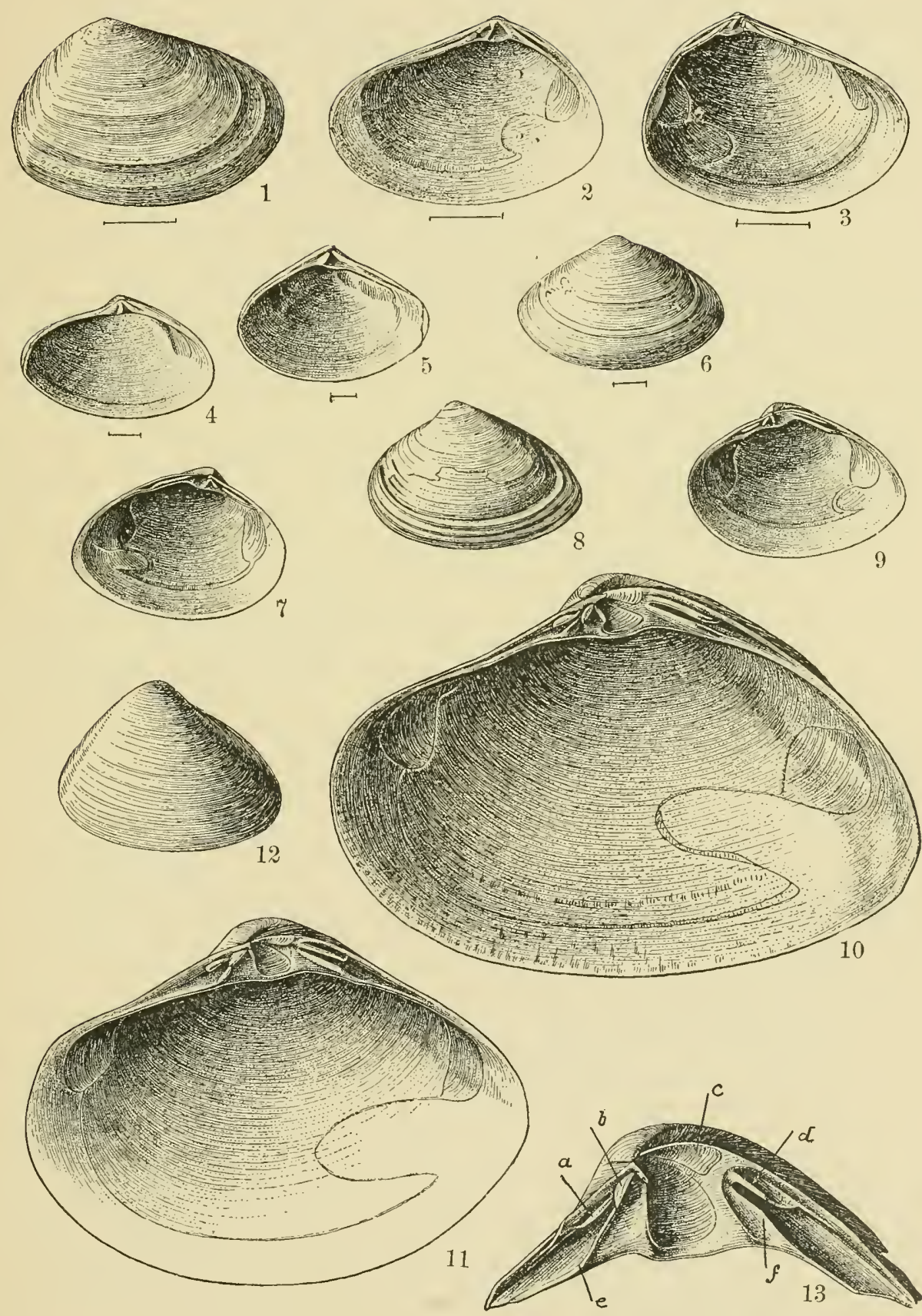


\section{PLATE LXX.}

Figs. 1-4. Spisula (Hemimactra) subronderosa (d'Orbigny)........ 288

1. Profile of hinge from above, left valve: $a$, anterior lateral; $b$, cardinal tooth; $c$, accessory lamella; $d$, spur with part of the cavity for the sagittal ligament below it; $e$, scar of attachment of ligament; $f$, posterior lateral lamina. $70 \mathrm{~mm}$. (After Dall.)

2. Exterior of right valve. St. Mary's River. $\quad \times 2 / 3$

3. Interior of left valve. St. Mary's River. $\quad \times 2 / 3$

4. Hinge-plate of left valve: $a$, dorsal and $e$, ventral posterior laminae; $b$, ligamentary scar not separated from the pit below by a septum; $c$, spur; $f$, accessory lamella; $i$, petaloid cardinal tooth; $d$, anterior lamina with $s$, absorption scar, from central lamina of opposite valve. $70 \mathrm{~mm}$. (After Dall.)

Figs. 5a, 5b. Sirisula (Heminactra) confraga (Conrad) ............ 289

5a. Exterior of left valve of type specimen. Patuxent River. Acad. Nat. Sci., Phila.

5 b. Interior of the same valve.

Figs. 6a, 6b. Spisula (Hemimactra) subparilis (Conrad)........... 289

6a. Interior of right valve. Plum Point. U. S. National Museum.

6b. Exterior of the same specimen. 



\section{PLATE LXXI.}

Fig. 1. Spisula (Heminactra?) chesapeakexisis n. sp. .......... 290

1. Exterior of right valve. 3 miles north of Plum Point. $\times 2 / 3$

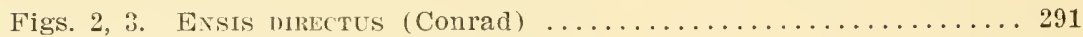

2. Interior of left valve. Yorktown, Va.

3. Exterior of right valve. Same locality.

Figs. 4-6. Exsis Exsifonuis Conrad..................... 292

4. Posterior portion of broken valve. St. Mary's River.

5. Posterior portion of broken valve. Same locality.

6. Interior of left valve. York River, Va.

Figs. 7a, 7b. Psam mobia gubernatoria n. sp.................. 292

7a. Interior of left valve. Jones Wharf.

7b. Exterior of same valve.

Figs. 8, 9. Asaphis centenalia (Conrad) 293

8. Interior of left valve. Jones Wharf.

9. Exterior of left valve. Same locality. 

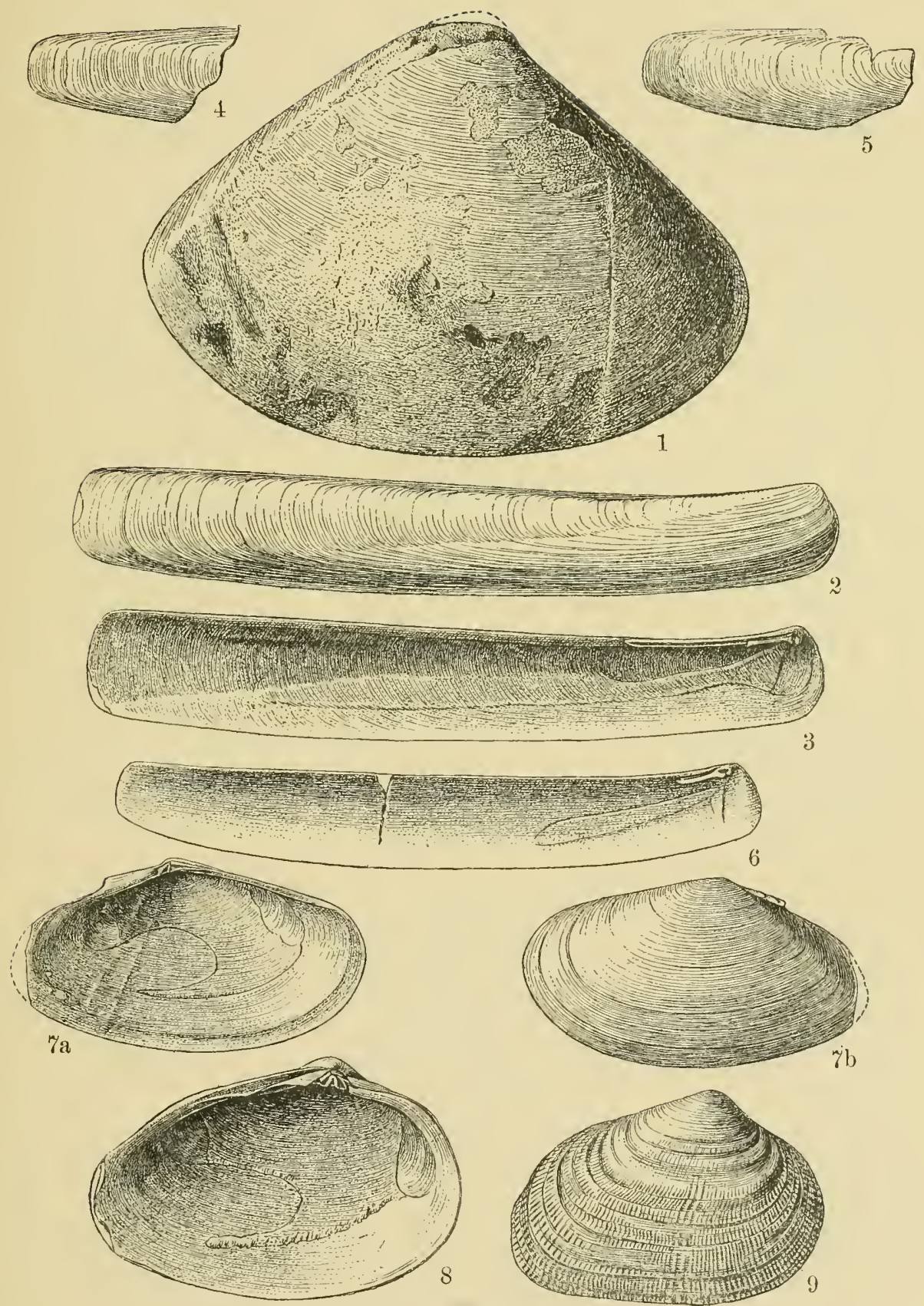
PLATE LXXII.

PAGE

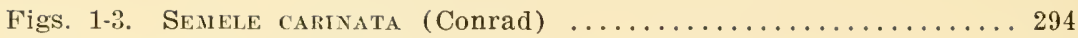

1. Exterior of right valve. St. Mary's River.

2. Interior of right valve. Same locality.

3. Exterior of left valve. Same locality.

Figs. 4, 5a, 5b. Semele carinata var. compacta Dall.............. 294

4. Exterior of right valve. St. Mary's River.

5a. Interior of right valve. Oligocene of Oak Grove, Fla. $16.5 \mathrm{~mm}$. (After Dall.)

5b. Exterior of valve of Fig. 5a. (After Dall.)

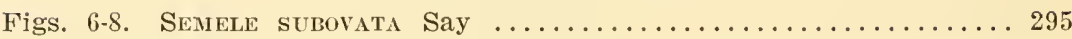

6. Exterior of right valve. Jones Wharf.

7. Interior of right valve. Same locality.

8. Exterior of left valve. Same locality.

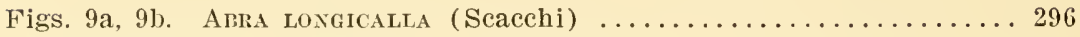

9a. Exterior of right valve. Jones Wharf.

$9 \mathrm{~b}$. Interior of same valve.

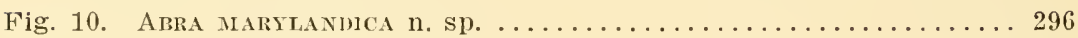

10. Interior of left valve. Plum Point.

Figs. 11, 12. Cumingia medialis Conrad................... 297

11. Exterior of left valve. Jones Wharf. (?)

12. Interior of left valve. Same locality.

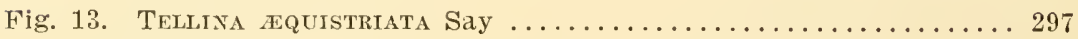

13. Exterior of left valve. Jones Wharf. (?)

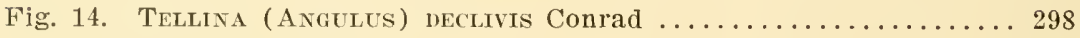

14. Exterior of left valve. Plum Point.

Figs. 15, 16. Tellina (Angulus) producta Conrad................ 299

15. Exterior of left valve. Plum Point.

16. Exterior of left valve. Cove Point. 

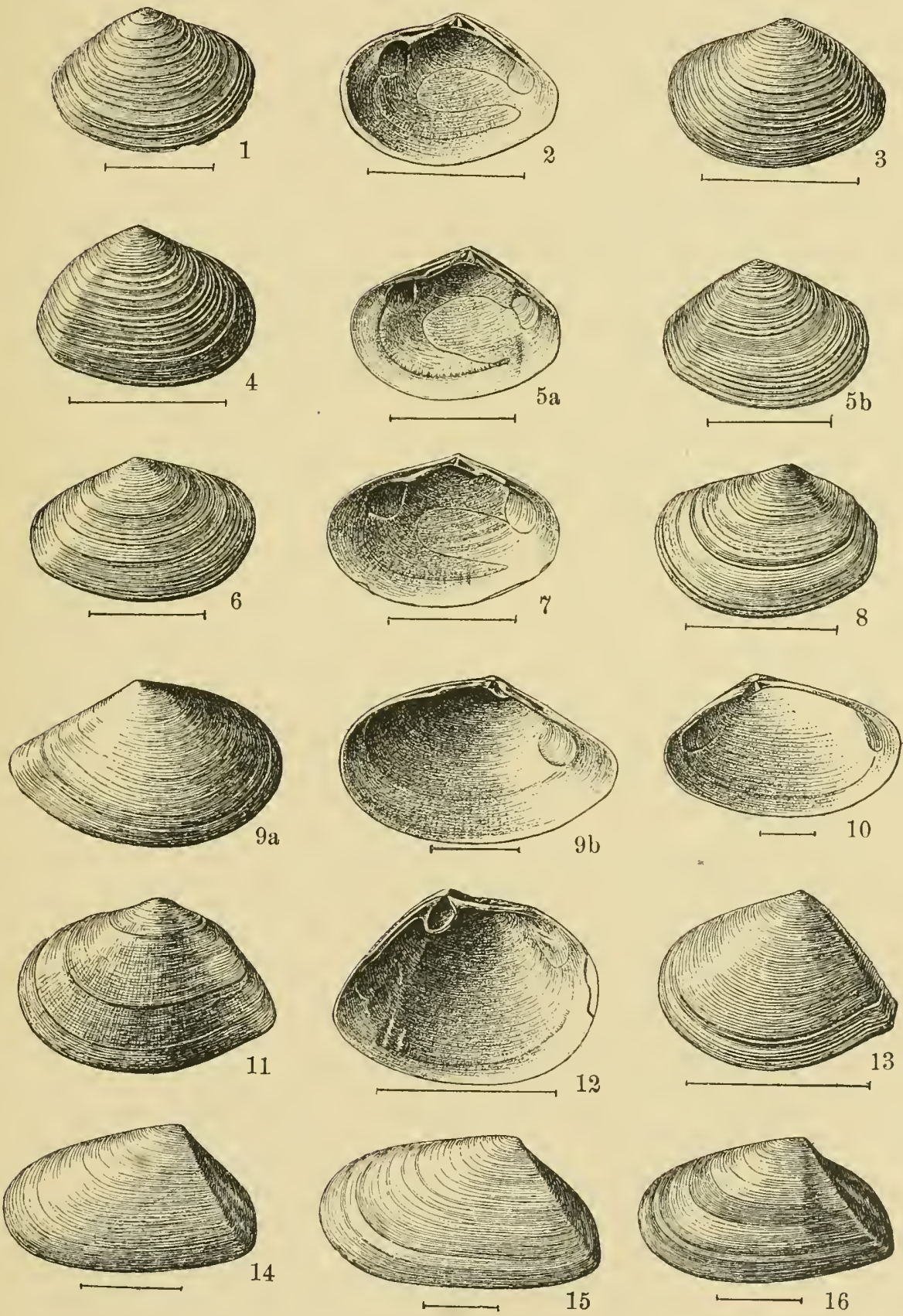

MOLLUSCA-PELECYPODA. 


\section{PLATE LXXIII.}

Fig. 1. Tellixa (Axgulus) depliniaxa Dall

1. Exterior of left valve. Duplin Co., N. C.; length $12.5 \mathrm{~mm}$. (After Dall.)

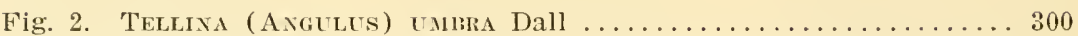

2. Exterior of left valve. Duplin Co., N. C.; length $12.5 \mathrm{~mm}$. (After Dall.)

Figs. 3, 4. Macoma Lenis (Conrad)

3. Interior of right valve. Jones Wharf.

4. Exterior of left valve. Same locality.

Figs. 5, 6. Metis biplicata Conrad

5. Interior of left valve. Jones Wharf.

6. Exterior of right valve. Same locality.

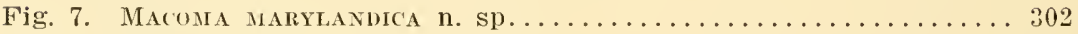

7. Interior of right valve.

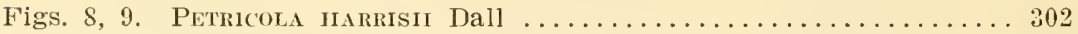

8. Exterior of right valve. Jones Wharf.

9. Interior of left valve. Same locality.

Figs. 10-12. Petricola (Petricolaria) caliertensis Dall............ 303

10. Exterior of right valve. Miocene of Maryland: length $17.5 \mathrm{~mm}$. (After Dall.)

11. Distorted right valve. Jones Wharf.

12. Left valve. Same locality.

Figs. 13, 14. Callocalida (Agriopona) sayana (Conrad) .......... 313

13. Exterior of right valve. Jones Wharf.

14. Interior of right valve. Same locality. 


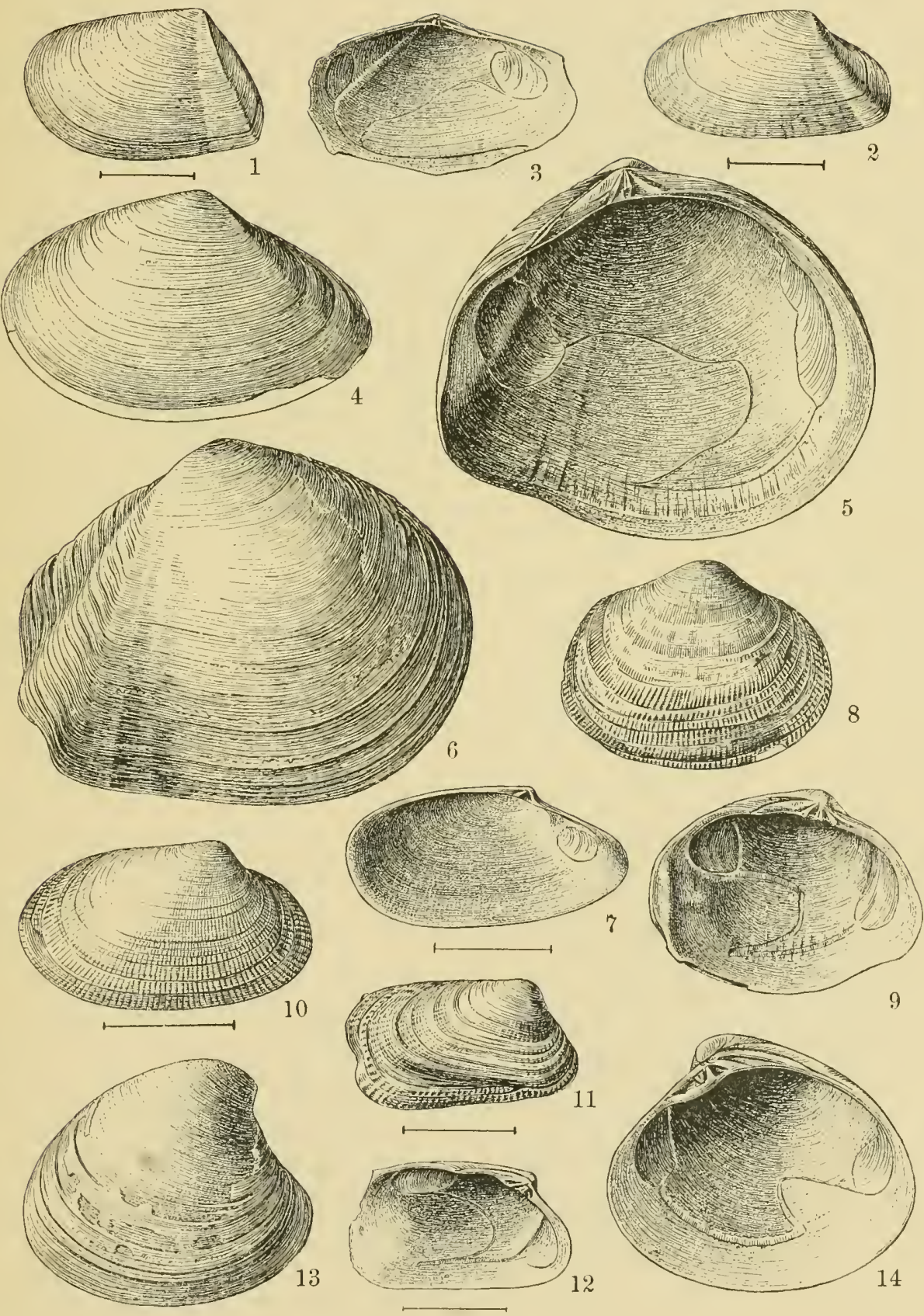


PLATE LXXIV.

Figs. 1, 2. Macrocallista alarylandica (Conrad) ............. 311

1. Interior of left valve. Jones Wharf.

2. Exterior of right valve. Same locality. 

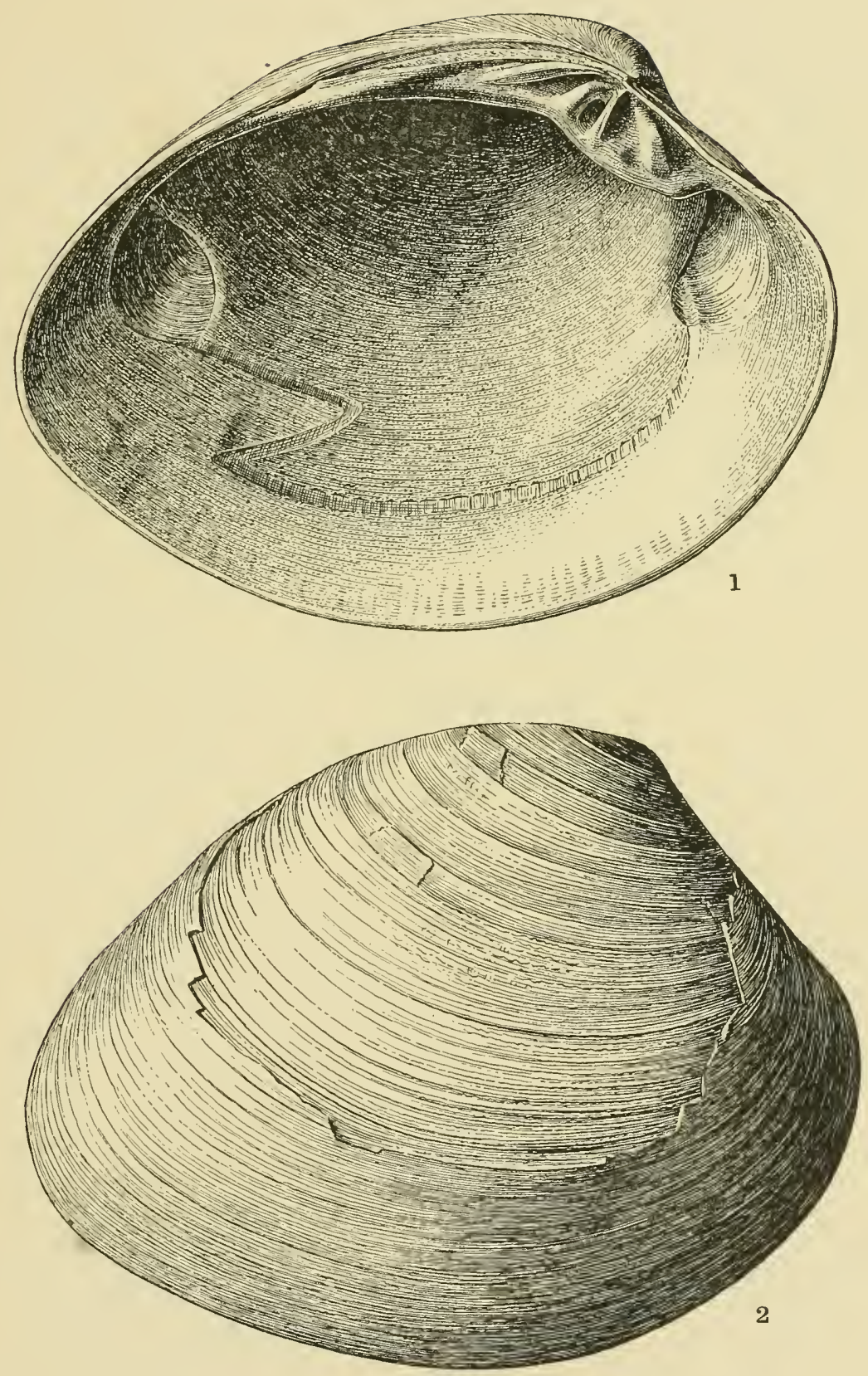

MOLLUSCA-PELECYPODA. 


\section{PLATE LXXV.}

PAGE

Figs. 1-3. Callocardia (Agriopoma) subrasuta (Comrad)........... 312

1. Exterior of right valve. St. Mary's River.

2. Interior of right valve. Same locality.

3. Exterior of right valve. Same locality.

Figs. 4-6. Callocardia (Agriopona) prunensis n. sp. ........... 313

4. Interior of right valve. Plum Point.

5. Exterior of left valve. Same locality.

6. Exterior of right valve. Same locality.

Figs. 7, 8. Venus ducatelr Conrad ...................... 304

7. Interior of left valve. Church Hill.

8. Exterior of right valve. Same locality. 

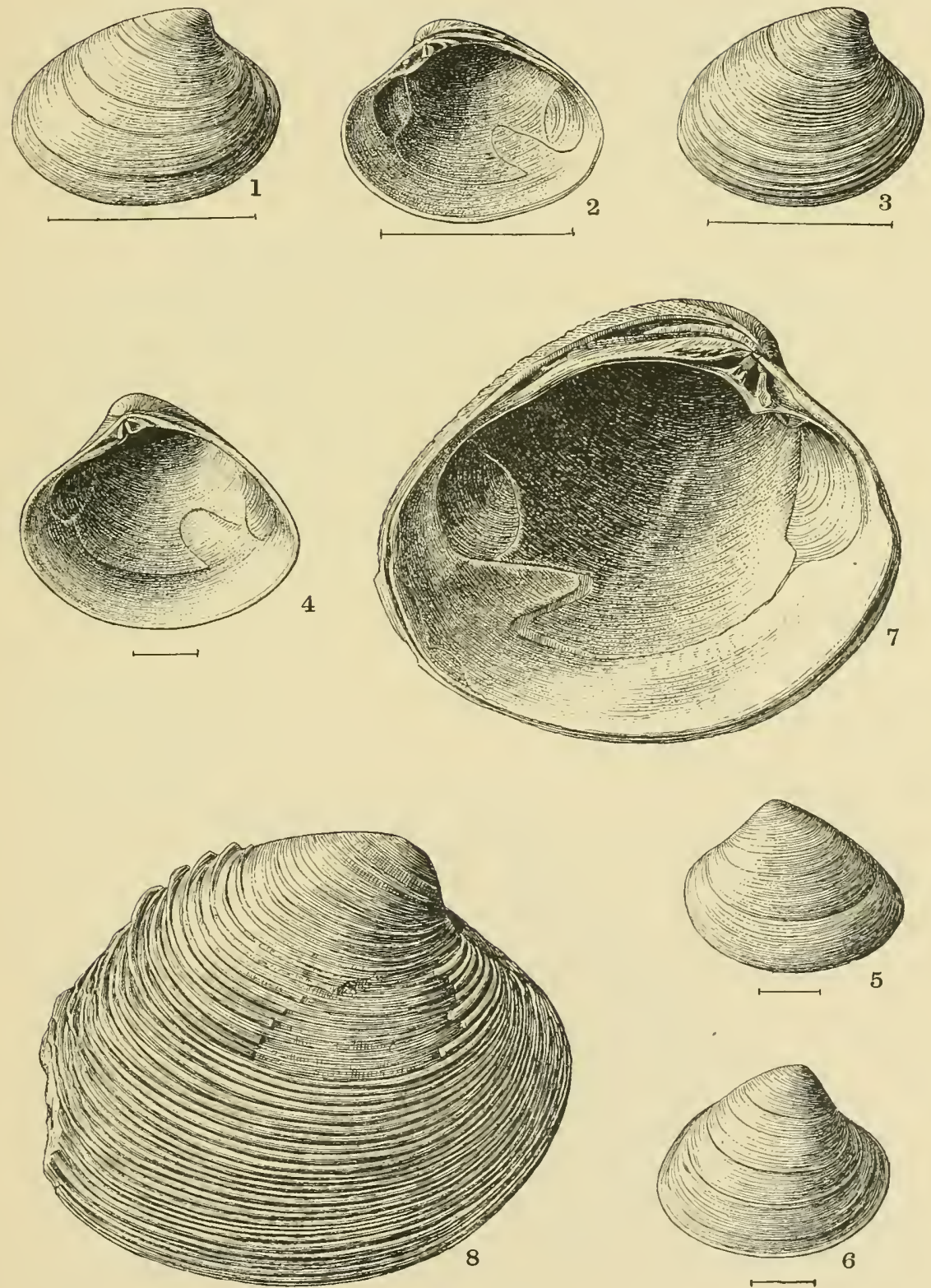

MOLLUSCA - PELECYPODA.

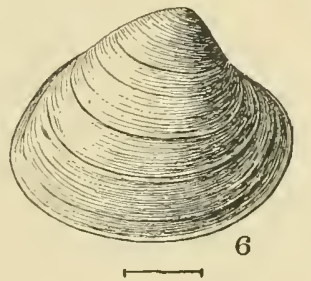

MOLIUSCA-TELECYTODA. 


\section{PLATE LXXVI.}

Figs. 1-3. Chione alveata (Conrad) ............................. 310

1. Interior of right valve. St. Mary's River.

2. Exterior of right valve. Same locality.

3. Exterior of right valve. Same locality.

Figs. 4, 5. Venus RILEYi Conrad...

4. Interior of left valve. Plum Point.

5. Exterior of right valve. Same locality.

Figs. 6-8. Crtherea (Antigoxa) staminea Conrad

6. Interior of right valve. Plum Point.

7. Exterior of left valve. Same locality.

8. Exterior of right valve. Same locality.

Figs. 9-11. Chione parkeria n. sp. 310

9. Exterior of right valve. Two miles south of Parlier's Creek.

10. Interior of right valve. Same locality.

11. Exterior of left valve. Same locality. 

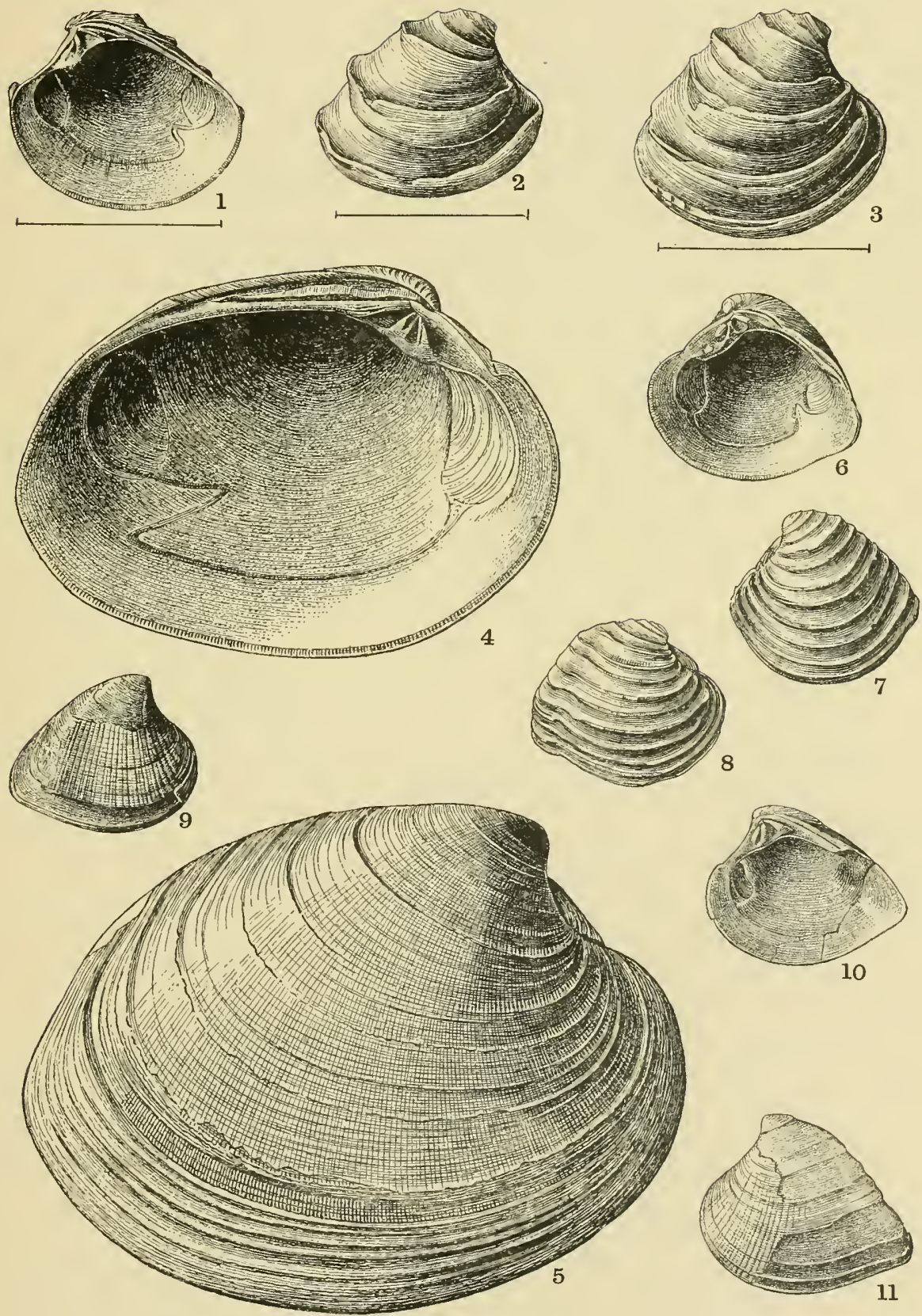

MOLLUSCA-PELECYPODA. 


\section{PLATE LXXVII.}

Figs. 1, 2. Venus CAMPechiensis var. Mortoni (Conrad) ........... 307

1. Exterior of right valve. Cove Point.

2. Interior of left valve. Same locality.

Figs. 3-6. Chione latilirata (Conrad) ..................... 309

3. Exterior of right valve. Plum Point.

4. Exterior of right valve. Same locality.

5. Dorsal view. The Pliocene of the Waccamaw beds, S. C., length $34 \mathrm{~mm}$. (After Dall.)

6. Interior view of right valve. Plum Point. 


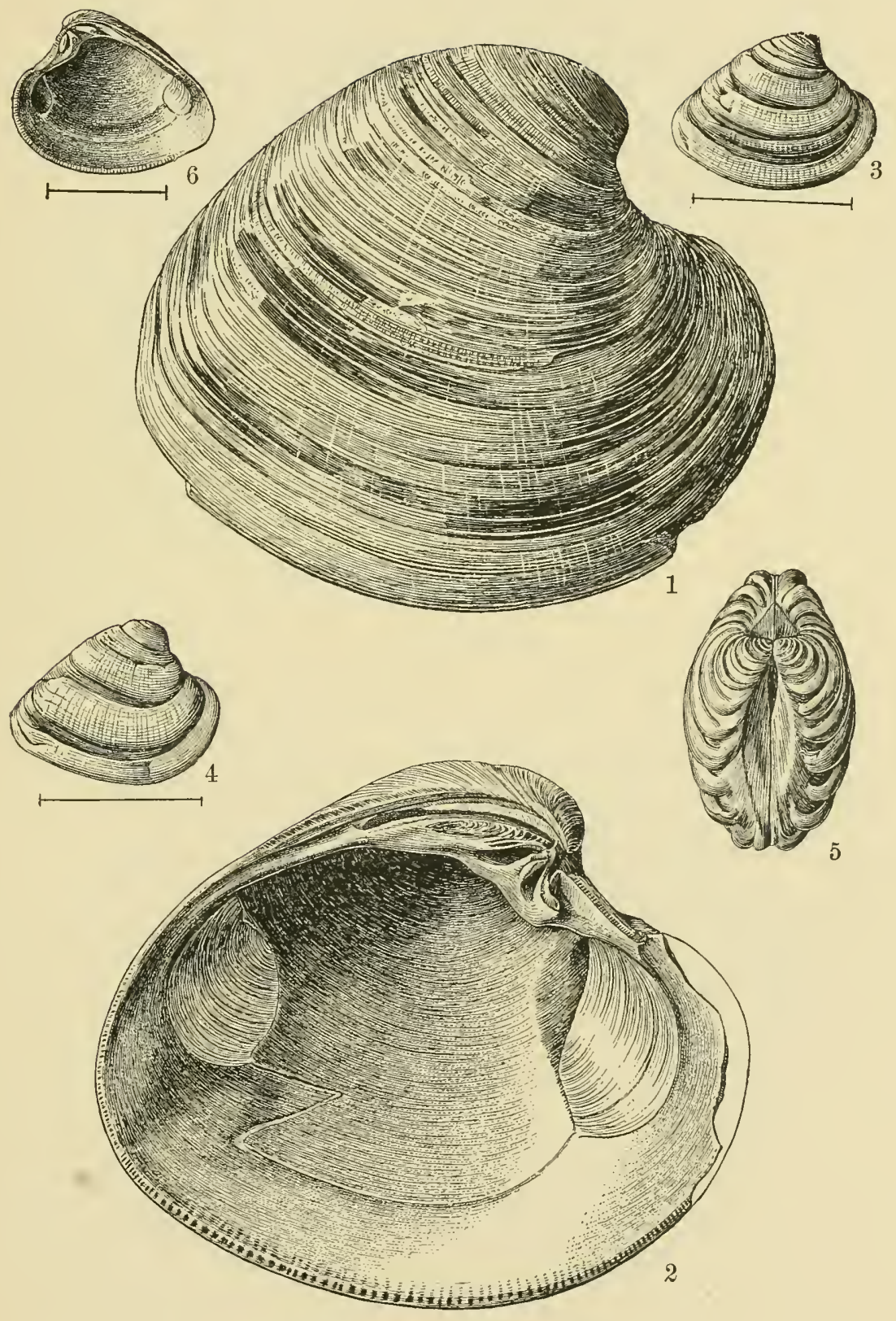

MOLLUSCA - PELECY PODA. 
PLATE LXXVIII.

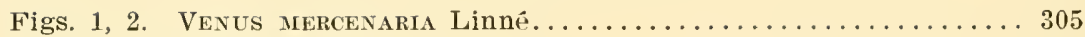

1. Interior of left valve. Plum Point.

2. Exterior of right valve. Same locality. 

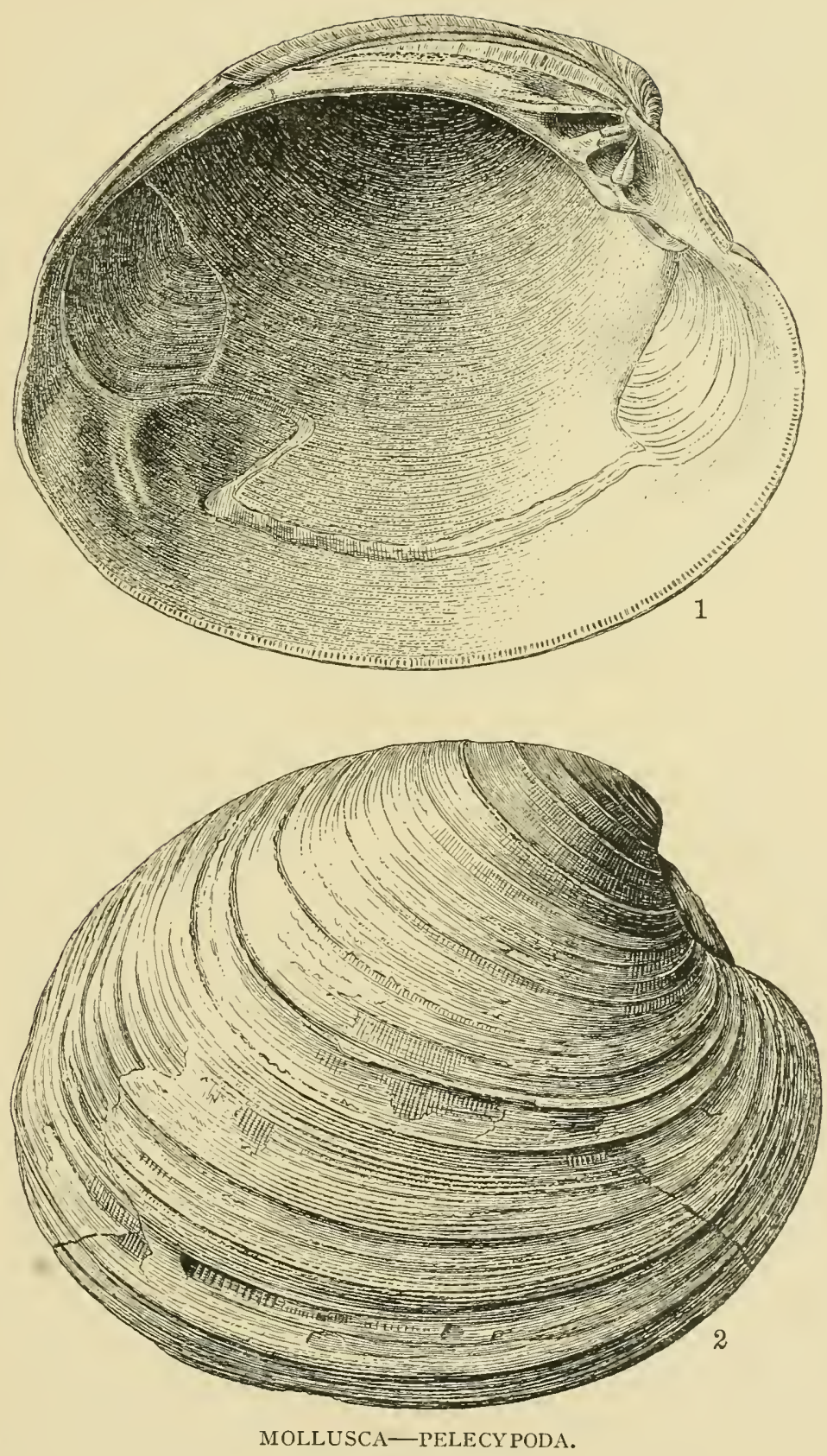


\section{PLATE LXXIX.}

PAGE

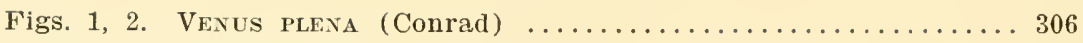
1. Interior of left valve. Governor's Run.

2. Exterior of right valve. Same locality. 

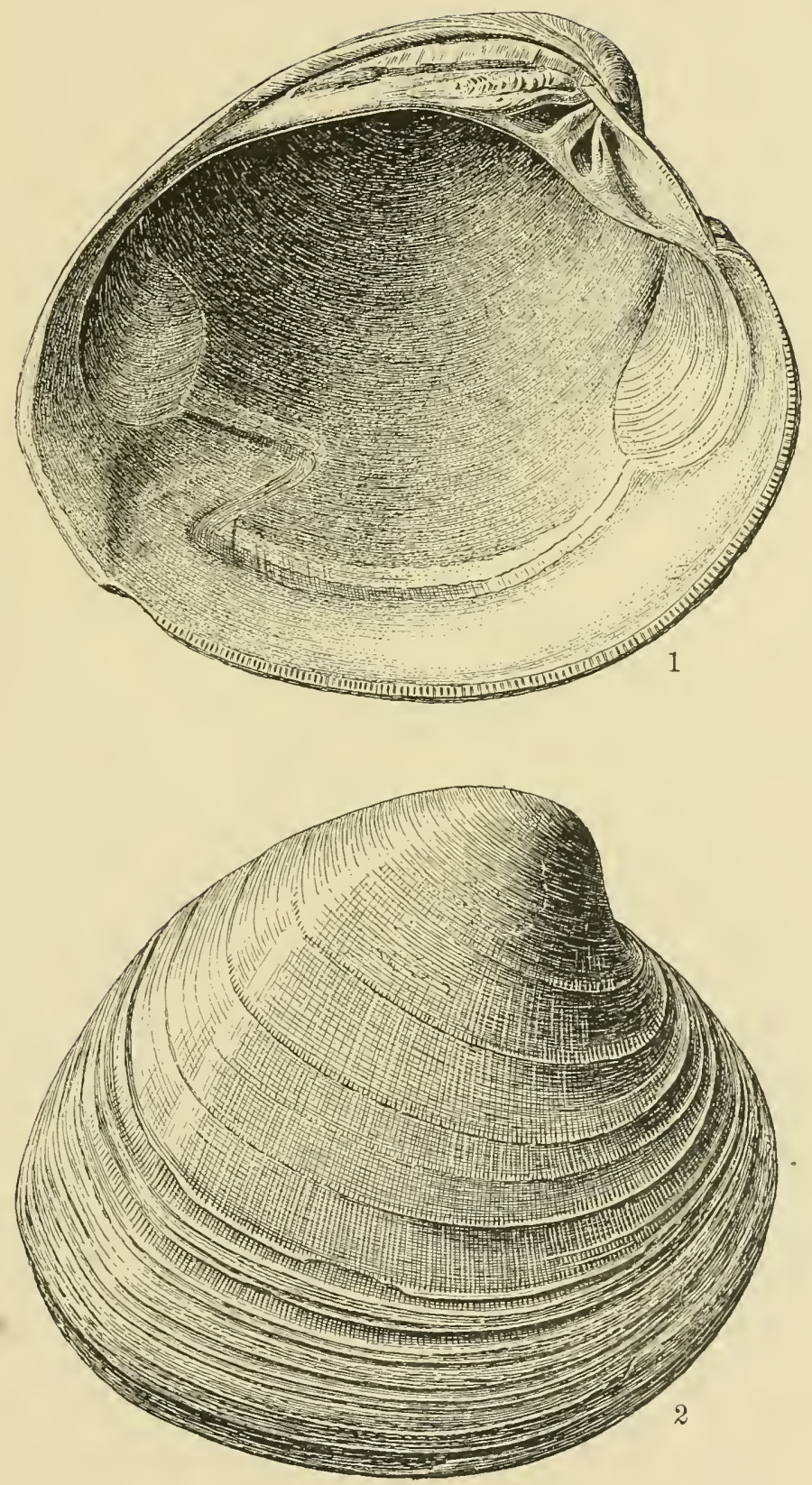

MOLLUSCA-PELECYPODA. 


\section{PLATE LXXX.}

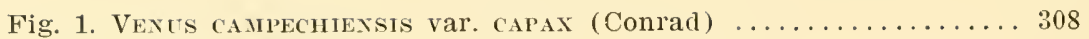
1. Exterior of right valve. Cordova.

Fig. 2. Vent's campecinensis var. Tetrica (Conrad) ............. 307 2. Exterior of right valve. St. Mary's River. 

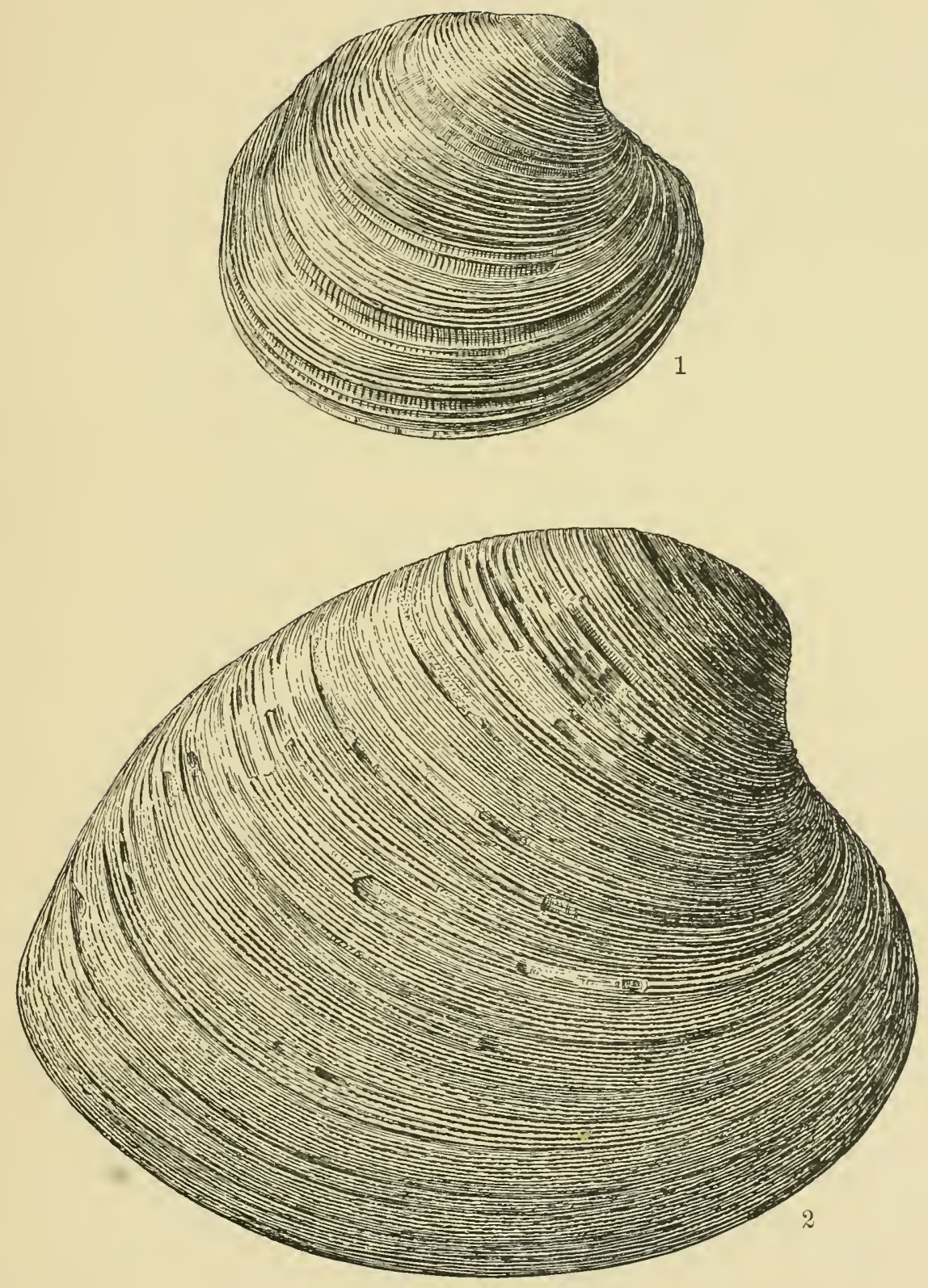

MOLLUSCA-PELECY PODA. 
PLATE LXXXI.

Fig. 1. Venus campecinensis var. Capax (Conrad) ............. 308 1. Interior of left valve. Cordova.

Fig. 2. Venus campechiensis var. tetrica (Conrad) .......... 307 2. Interior of left valve. St. Mary's River. 

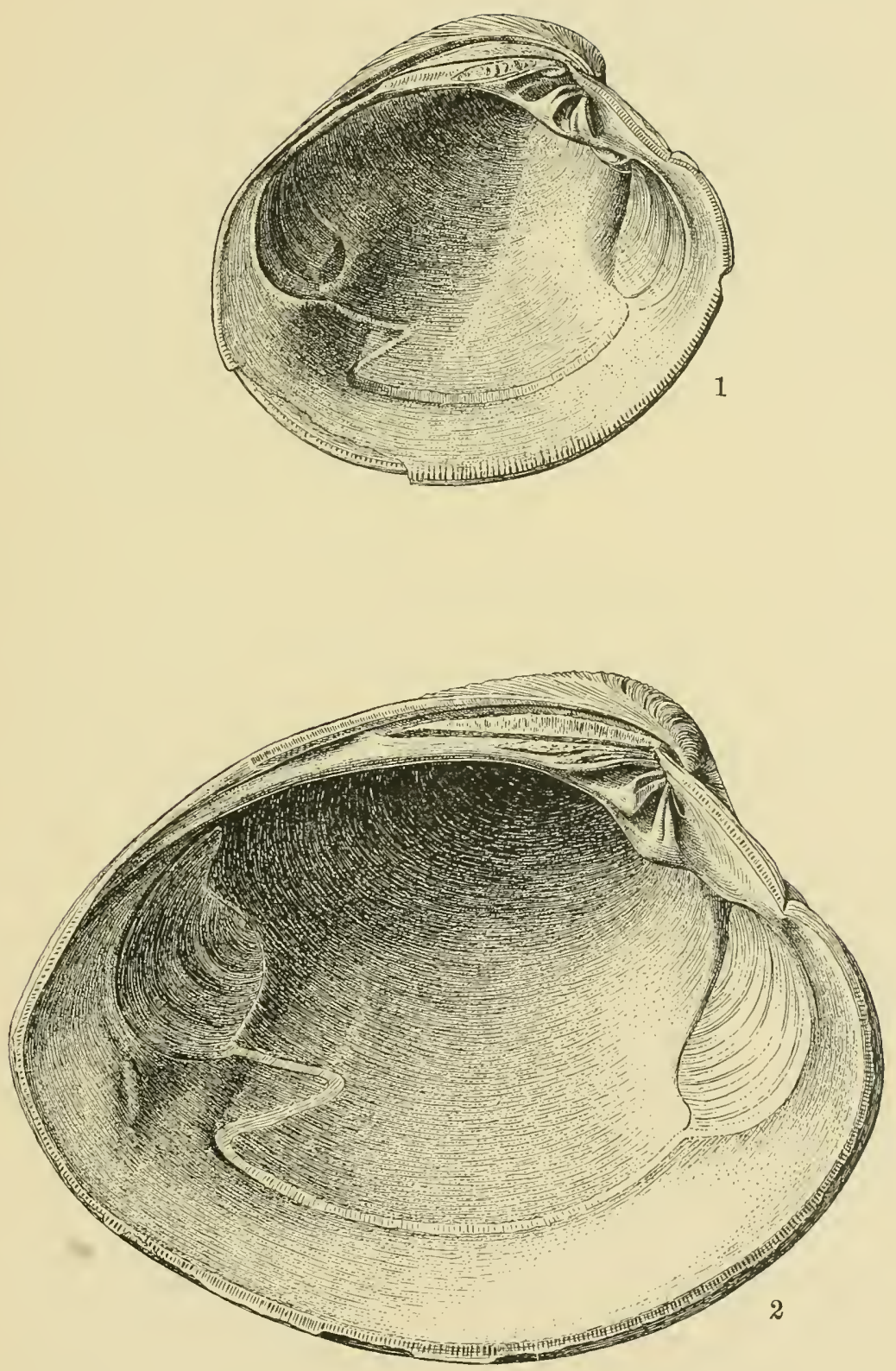

MOLLUSCA-PELECYPODA. 
PLATE LXXXII.

Figs. 1, 2. Clementia INoCeriformis (Wagner)

1. Exterior of left valve. Cove Point.

2. Interior of broken right valve. Same locality.

Fig. 3. Venus CAMPEChiensis var. Cuneata (Conrad)

3. Interior of left valve. Jones Wharf. 

PLATE LXXXIII.

Fig. 1. Dosinia acetabulum Conrad ............................... 315

1. Exterior of right valve. St. Mary's River.

Fig. 2. Venus campechiensis var. cuneata (Conrad) $\ldots \ldots \ldots \ldots \ldots . . \ldots 8$

2. Exterior of right valve. Jones Wharf. 

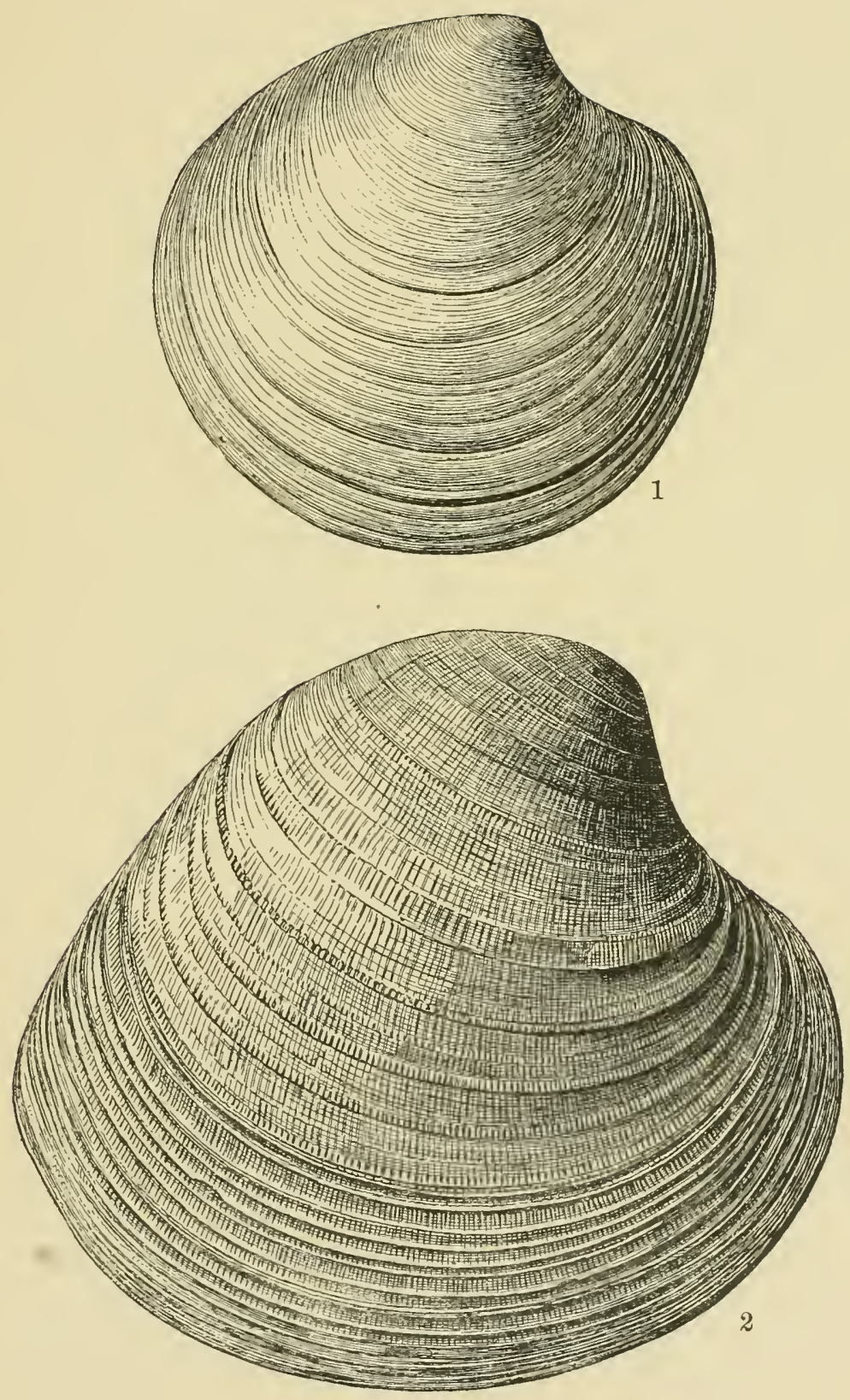

MOLLUSCA-PELECYPODA. 
PLATE LXXXIV.

Fig. 1. Dosinia acetabulum Conrad

1. Interior of left valve. St. Mary's River.

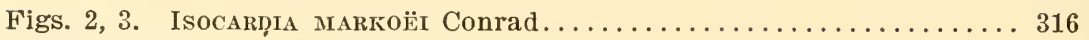

2. Exterior of right valve. Plum Point.

3. Interior of left valve. Same locality.

Figs. 4, 5. Isocardia mazlea n. sp.

4. Exterior of right valve. Plum Point.

5. Interior of left valve. Same locality. 

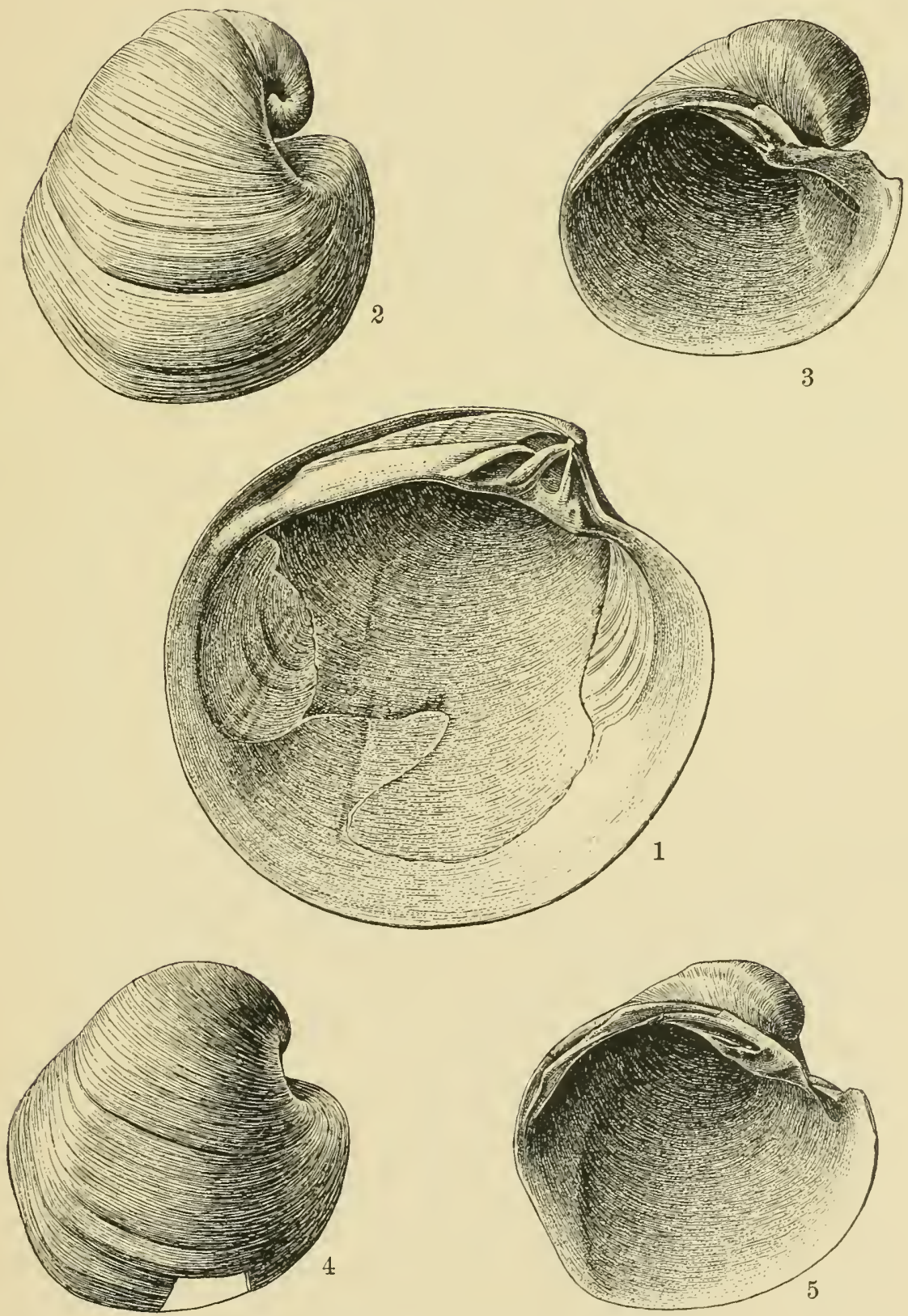

MOLLUSCA-PELECY PODA. 
PLATE LXXXV.

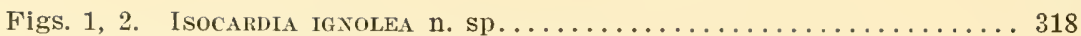

1. Exterior of right valve. Cove Point?

2. Interior of left valve of same individual.

Figs. 3, 4. Isocardia fraterna Say $\ldots \ldots \ldots \ldots \ldots \ldots \ldots \ldots \ldots \ldots \ldots \ldots \ldots \ldots \ldots \ldots$

3. Exterior of right valve. Jones Wharf.

4. Interior of left valve. Same locality. 


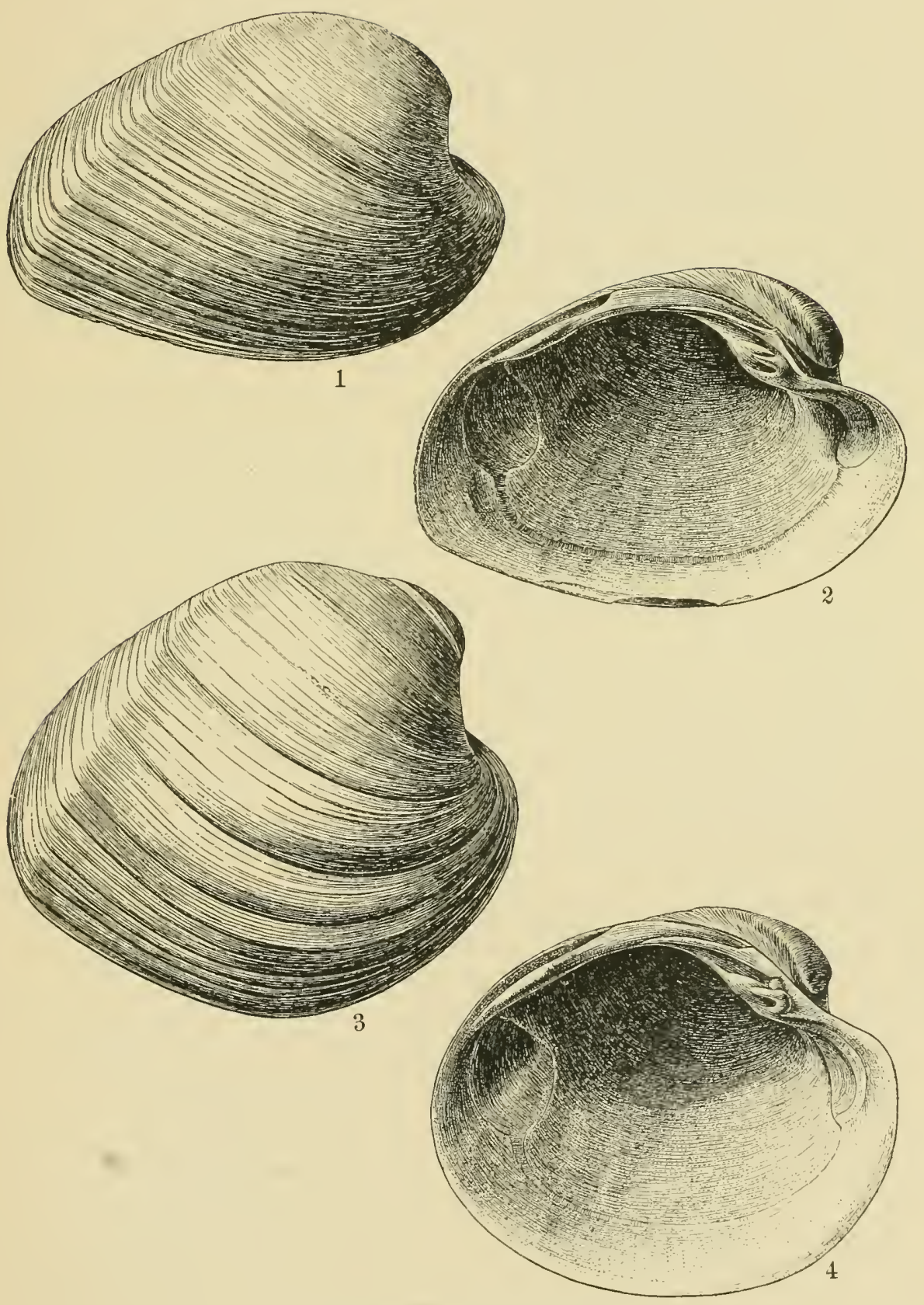

MOLLUSCA-PELECYPODA. 
PLATE LXXXVI.

Fig. 1. Cardium (Cerastoderma) laqueatum Conrad .............. 319

1. Exterior of left valve. Jones Wharf. $\times 2 / 3$

Fig. 2. Cardium (Cerastoderma) leptopleurum Conrad ........... 320

2. Exterior of right valve. Plum Point.

Fig. 3. Cardium (Cerastoderata) craticulolde Conrad ............ 320

3. Exterior of left valve. Plum Point.

Fig. 4. Cardium (Cerastoderma) calvertensium n. sp............ 321

4. Exterior of right valve. Governor's Run (lower bed).

Fig. 5. Cardium (Cerastoderma) patuxentium n. sp. ........... 322

5. Exterior of right valve. White's Landing.

Figs. 6a, 6b. Cardium (Fragum) medium Linné................ 322

6a. Interior of right valve. St. Mary's River. U. S. National Museum.

6 b. Exterior of the same valve.

Figs. 7a, 7b. Cardium (Leticardium) mortoni Conrad............ 323

7a. Exterior of right valve. Jones Wharf. U. S. National Museum.

$7 \mathrm{~b}$. Interior of the same valve. 

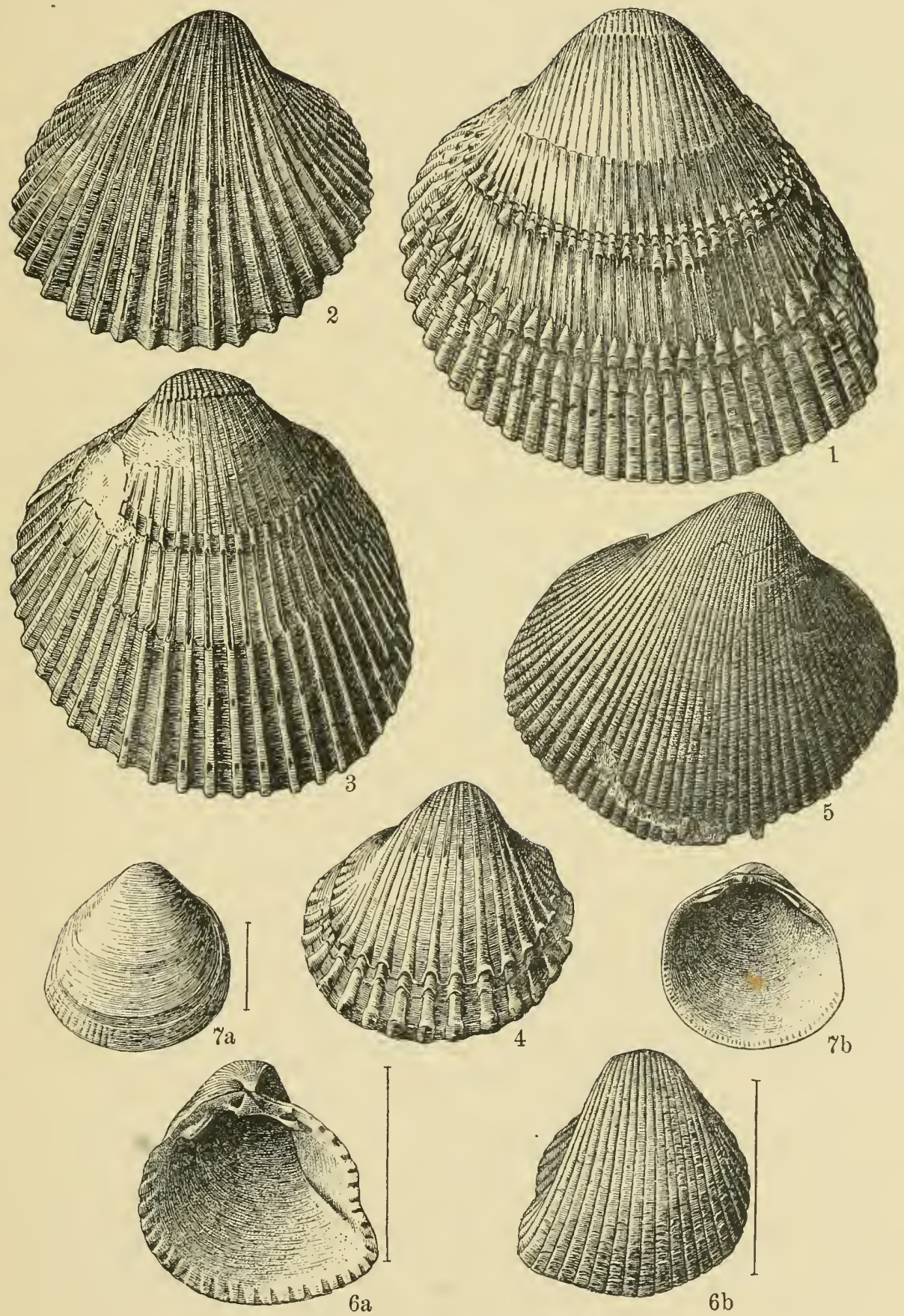

MOLLUSCA-PELECY PODA. 


\section{PLATE LXXXVII.}

Figs. 1-4. Solecarda (Spaniorinus) cossmanni Dall

1. Interior of right valve. Miocene of Virginia. U. S. National Museum. (After Dall.)

1a. Hinge of left valve. Same locality and collection. (After Dall.)

2. Interior of right valve. Cove Point.

3. Interior of left valve. Same locality.

4. Exterior of right valve. Same locality.

Figs. 5a, 5b. Spor'tella whitfield Dall

5a. Interior of right valve. Plum Point.

5 b. Exterior of same valve.

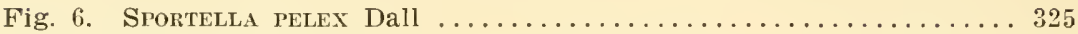

6. Interior of right valve. Miocene of Virginia. U. S. National Museum. (After Dall.)

Fig. 7. Sportella petropolitana Dall

7. Interior of right valve. Petersburg, Virginia. U. S. National Museum. (After Dall.)

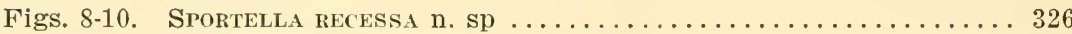

8. Interior of left valve. Cove Point.

9. Exterior of left valve. Same locality.

10 Interior of right valve. Same locality. U. S. National Museum.

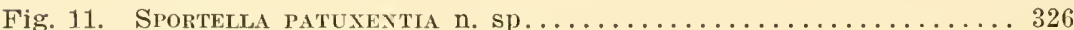

11. Interior of right valve. Cove Point.

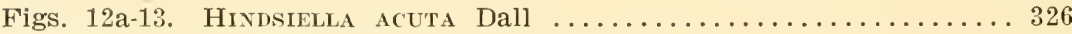

12a. Interior of left valve. St. Mary's River.

12b. Exterior of same specimen.

13. Interior of left valve. Miocene of North Carolina. U. S. National Museum.

Figs. 14, 15. Erycina (Pseudopythina?) americana Dall........... 329

14. Exterior of right valve. Calvert Cliffs. U. S. National Museum. (After Dall.)

15. Interior of left valve. Same locality and collection. (After Dall.)

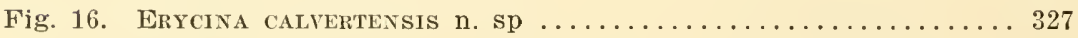

16. Interior of right valve. Plum Point.

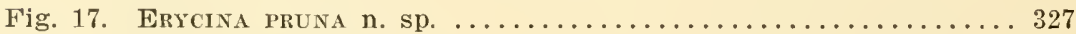

17. Interior of right valve. Plum Point. 

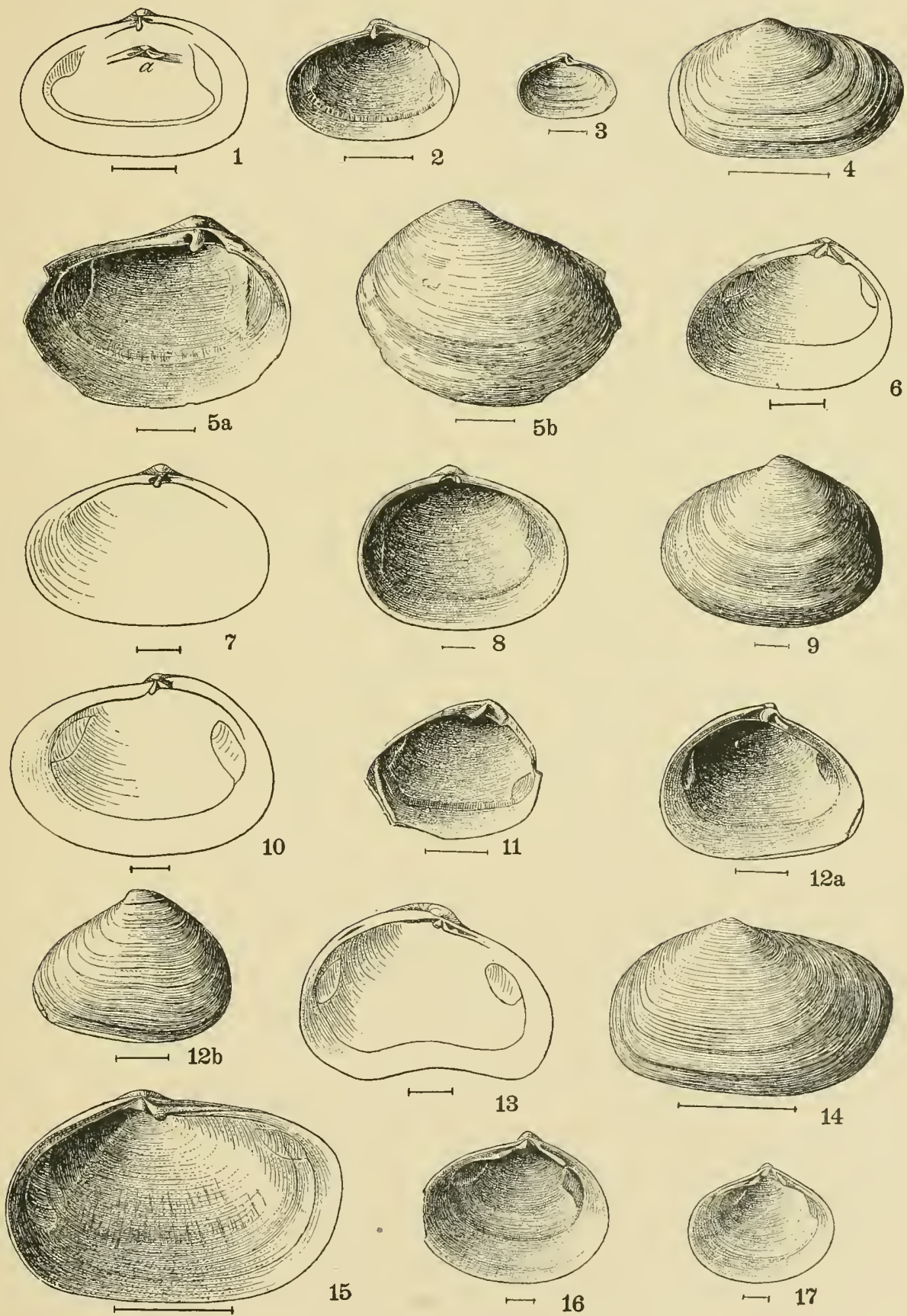

MOLLUSCA-PELECY PODA. 


\section{PLATE LXXXVIII.}

Figs. 1-3. ERycina marylandica n. sp.

1. Exterior of left valve. Three miles south of Chesapeake Beach.

2. Interior of right valve. Same locality.

3. Interior of right valve. Plum Point. U. S. National Museum. (After Dall.)

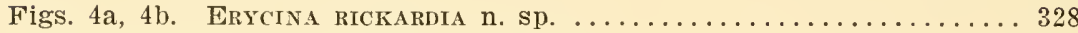

4a. Interior of right valve. Plum Point.

4b. Exterior of same valve.

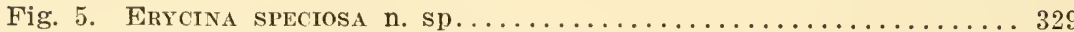

5. Interior of right valve. Plum Point.

Figs. 6-8. Bornia MaCtroides (Conrad) .................. 330

6. Interior of left valve. Dover Bridge.

7. Exterior of right valve. Same locality.

8. Interior of right valve. Same locality.

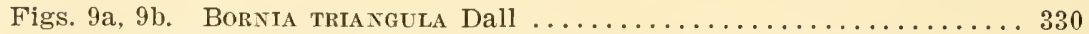

9a. Interior of right valve. Three miles west of Centerville.

$9 \mathrm{~b}$. Exterior of same valve.

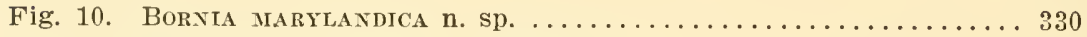

10. Interior of right valve. Greensboro.

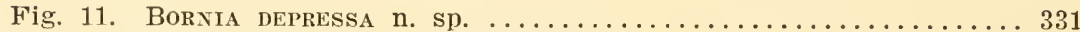

11. Interior of right valve. Plum Point.

Figs. 12, 13. Kellia rotundula n. sp.

12. Interior of right valve. Governor's Run.

13. Interior of left valve. Same locality.

Figs. 14-18. Thecodonta (Dicranodesian) Calvertensis n. sp. ...... 332

14. Interior of right valve. Plum Point.

15. Interior of left valve. Same locality.

16. Exterior of left valve. Same locality.

17. Interior of left valve. Plum Point. U. S. National Museum. (After Dall.)

18. Interior of right valve. Plum Point. U. S. National Museum. (After Dall.)

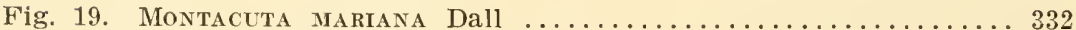

19. Interior of right valve. St. Mary's River or Plum Point. U. S. National Museum. (After Dall.)

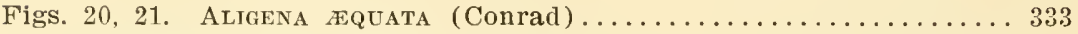

20. Exterior of left valve. Jones Wharf.

21. Exterior of right valve. Same locality. 

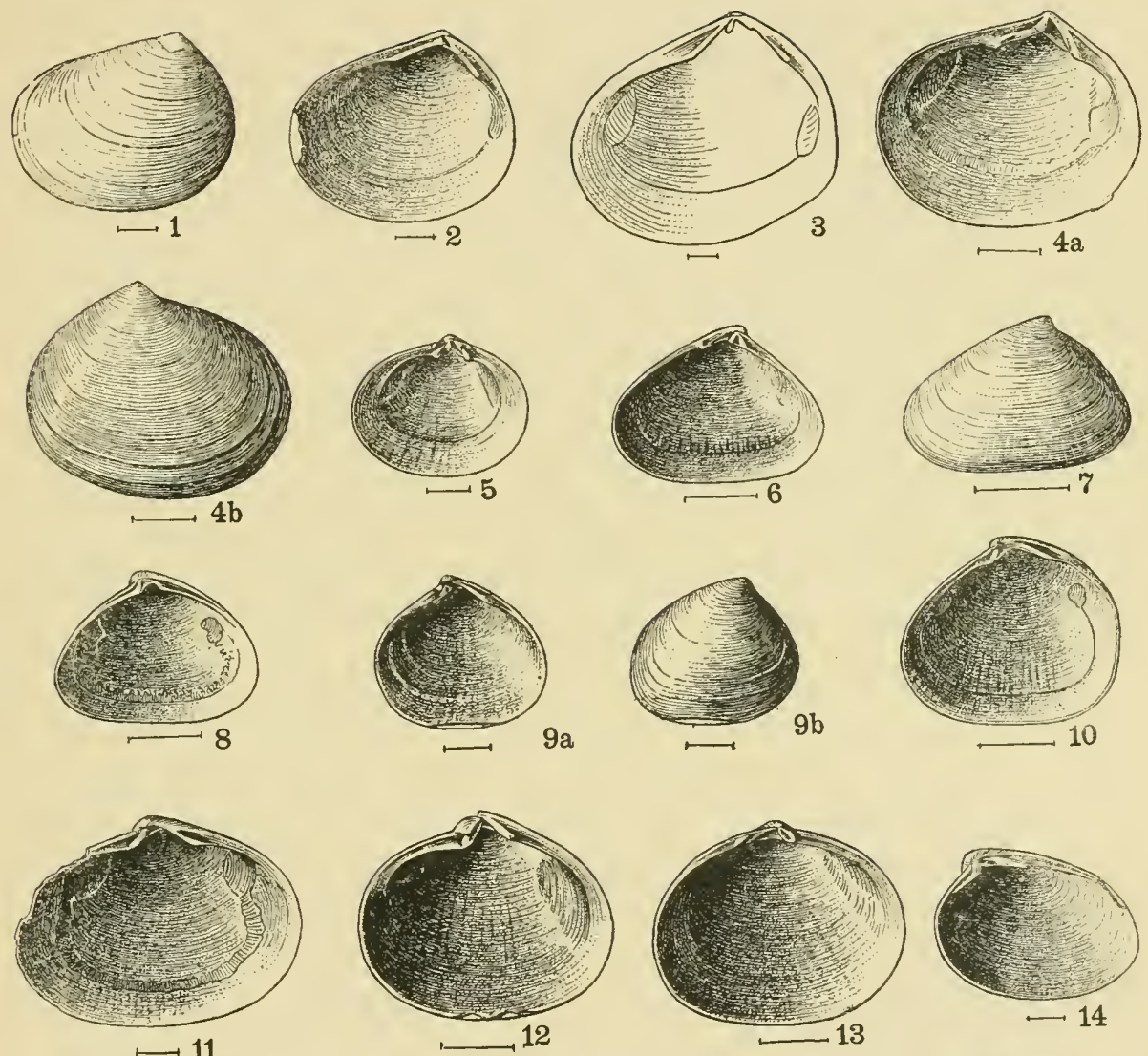

$\longmapsto 11$
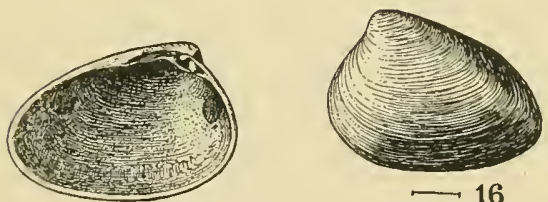

$\longrightarrow 16$
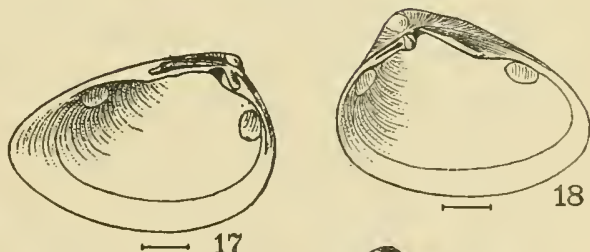

15
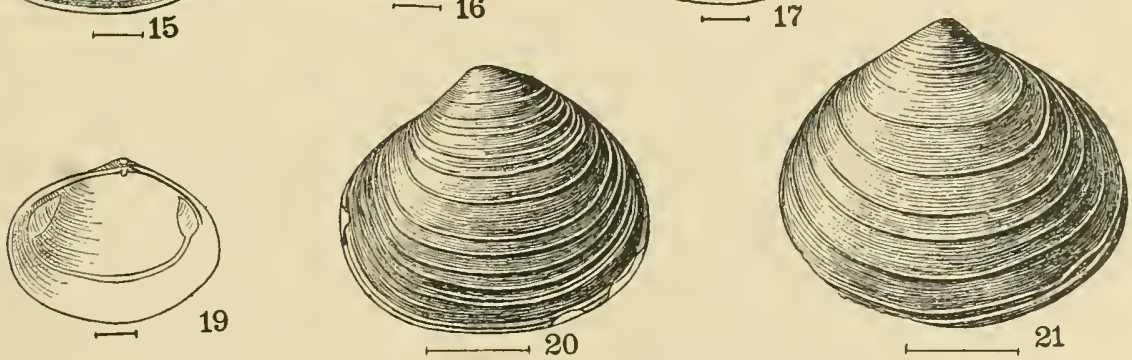

MOLLUSCA-PELECYPODA. 


\section{PLATE LXXXIX.}

Figs. 1-3. Aligena ÆQUata (Conrad).

1. Interior of left valve. Jones Wharf.

2a. Interior of left valve. Miocene of Virginia. U. S. National Museum. (After Dall.)

2b. Exterior of the same valve. (After Dall.)

3. Interior of right valve. Miocene of Virginia. U. S. National Museum. (After Dall.)

Fig. 4. Aligena equata var. NUdA Dall.

4. Exterior of right valve. Plum Point.

Figs. 5a, 5b. Aligena pustulosa Dall ............................... 334

5a. Interiol of left valve. Oligocene of Oak Grove, Florida. U. S.

National Museum. (After Dall.)

5b. Exterior of same specimen. (After Dall.)

Figs. 6a, 6b. Diplononta Acclinis Conrad ........................ 334

6a. Interior of right valve. Caloosahatchie beds. U. S. National Museum. (After Dall.)

6b. Exterior of same valve. (After Dall.)

Figs. 7, 8. Diplodonta shilohensis Dall

7. Exterior of left valve. Jones Wharf.

8. Interior of right valve. Same locality.

Figs. 9, 10. Diplodonta subvexa (Conrad)

9. Interior of right valve. Flag Pond.

10. Exterior of left valve. Same locality. 

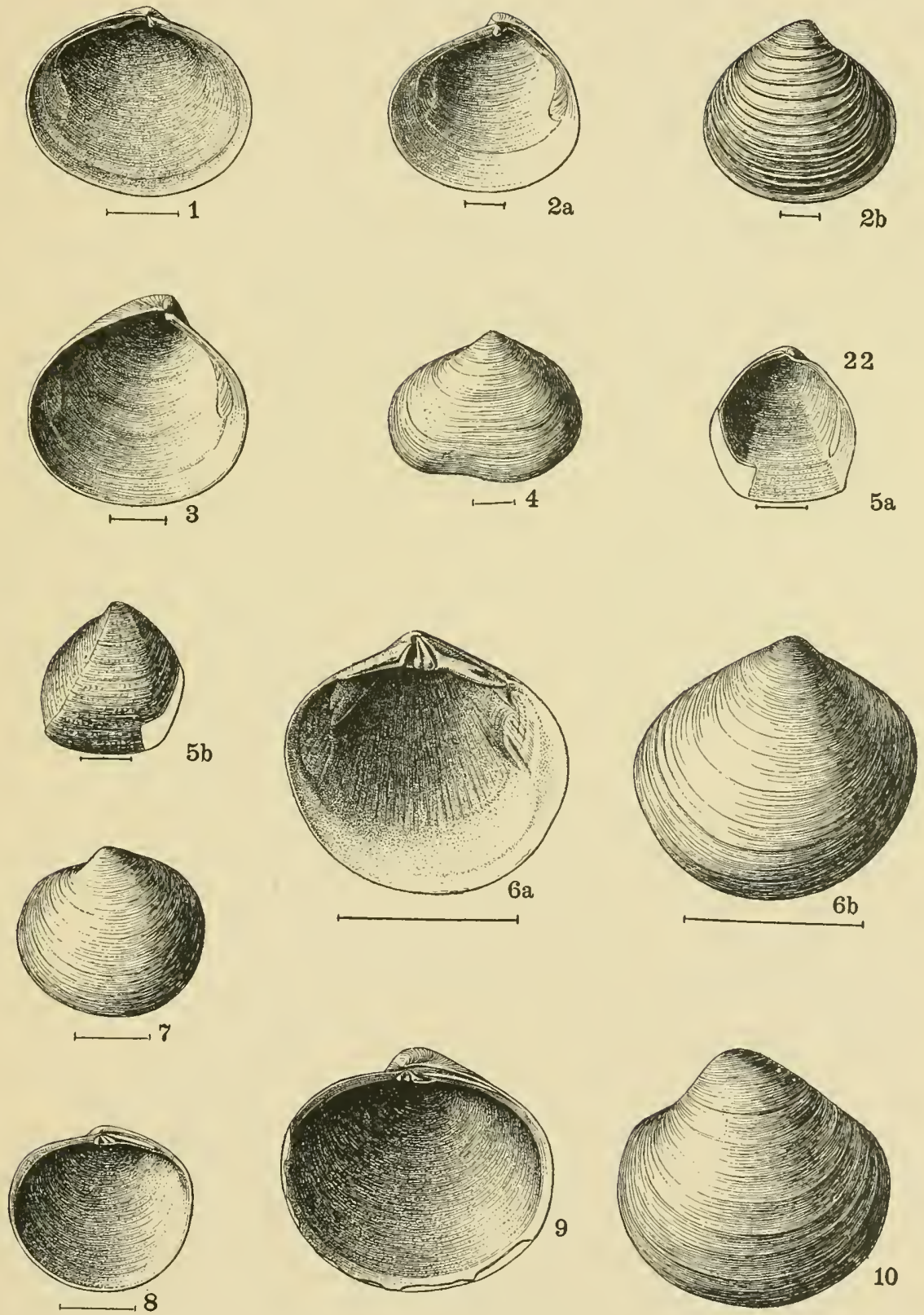

MOLLUSCA-PELECYPODA. 
PLATE XC.

PAGE

Figs. 1, 2. Phacoides (Pseunomiltha) Fonemani (Conrad) ........ 336

1. Interior of left valve. Plum Point.

2. Exterior of right valve. Same locality.

Figs. 3, 4. Pilacoides (Pseudomiltila) anodonta (Say)............ 337

3. Interior of left valve. Jones Wharf.

4. Exterior of right valve. Same locality.

Figs. 5, 6. Phacoides (Lucinoma) contractus (Say) . . . . . . . . . . 339

5. Interior of left valve. Pawpaw Point.

6. Exterior of right valve. Same locality.

Figs. 7-9. Phacomes (Here) trisulcatus (Conrad).............. 337

7. Interior of left valve. Plum Point.

8. Exterior of right valve. Same locality.

9. Interior of right valve. Same locality.

Figs. 10-12. Pilacoides (Parvilucina) crenulatus (Conrad)......... 340

10. Interior of left valve. Cove Point.

11. Exterior of right valve. Same locality.

12. Interior of right valve. Same locality.

Fig. 13. Phacoides (Parvilucina) prunus Dall ....................... 340

13. Exterior of left valve. Plum Point. U. S. National Museum. (After Dall.) $\times 3$. 


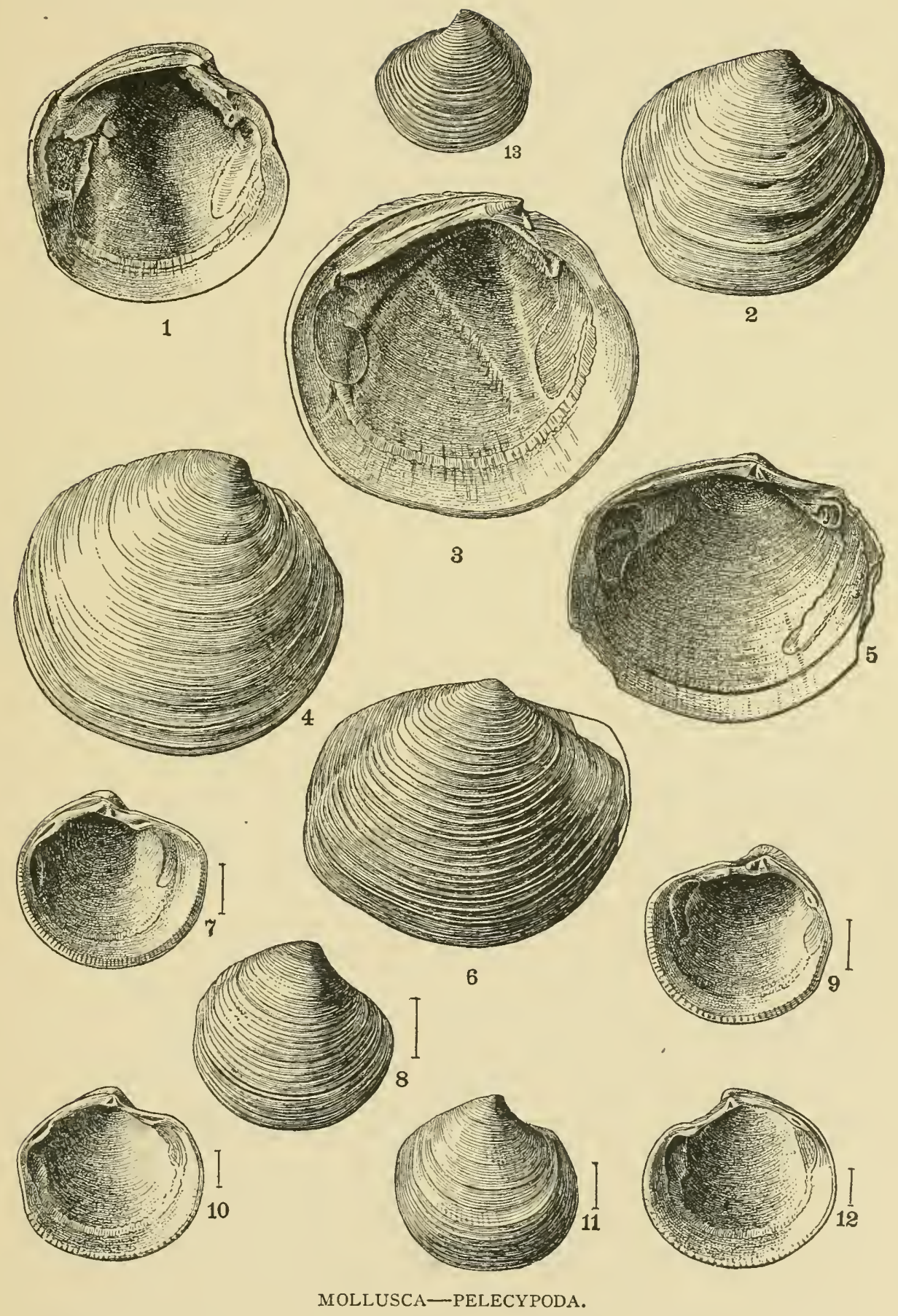


PLATE XCI.

Figs. 1-3. Chama congregata Conrad

1. Interior of left valve. Church Hill.

2. Exterior of right valve. Same locality.

3. Exterior of right valve. Same locality.

Figs. 4-6. Cardita protracta (Conrad)

4. Exterior of right valve. Governor Run.

5. Exterior of right valve. Same locality.

6. Interior of left valve. Same locality.

Figs. $7-10$. Venericardia granulata Say ...................... 344

7. Exterior of right valve, large variety. St. Mary's River.

8. Interior of left valve. Same locality.

9. Interior of left valve, smaller variety. Plum Point.

10. Exterior of right valve, smaller variety. Same locality.

Figs. 11, 12. Venericardia castrana n. sp 345

11. Exterior of right valve. Church Hill.

12. Interior of left valve. Same locality. 

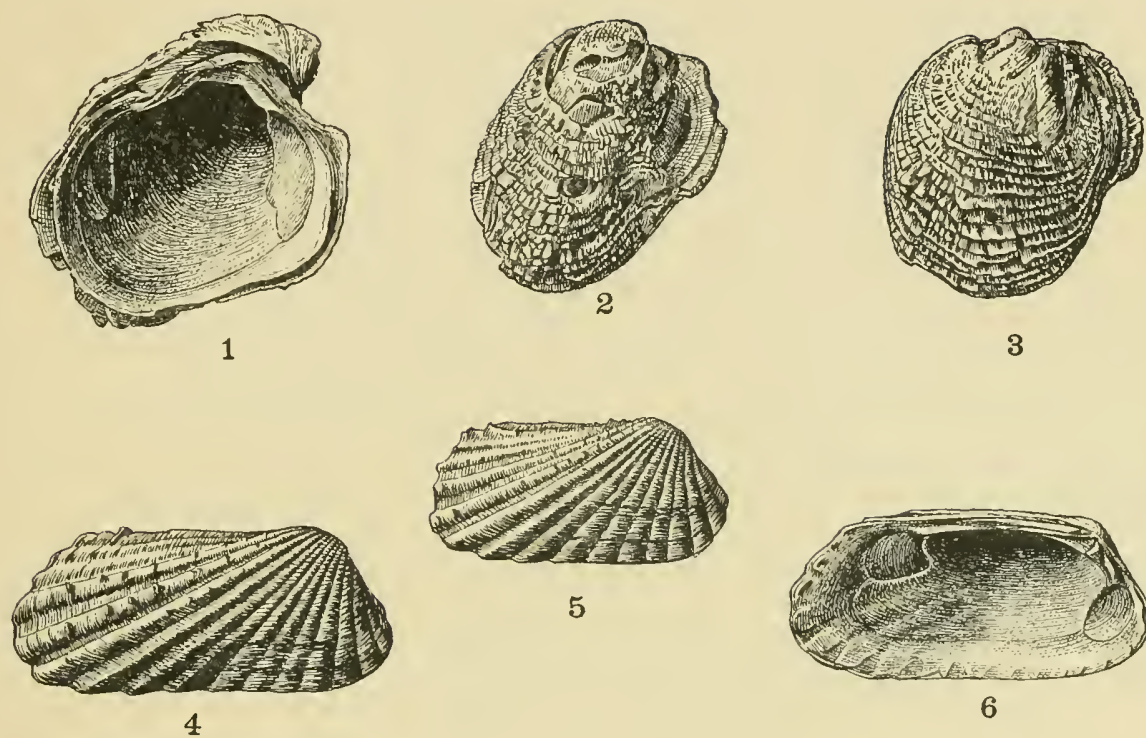

5
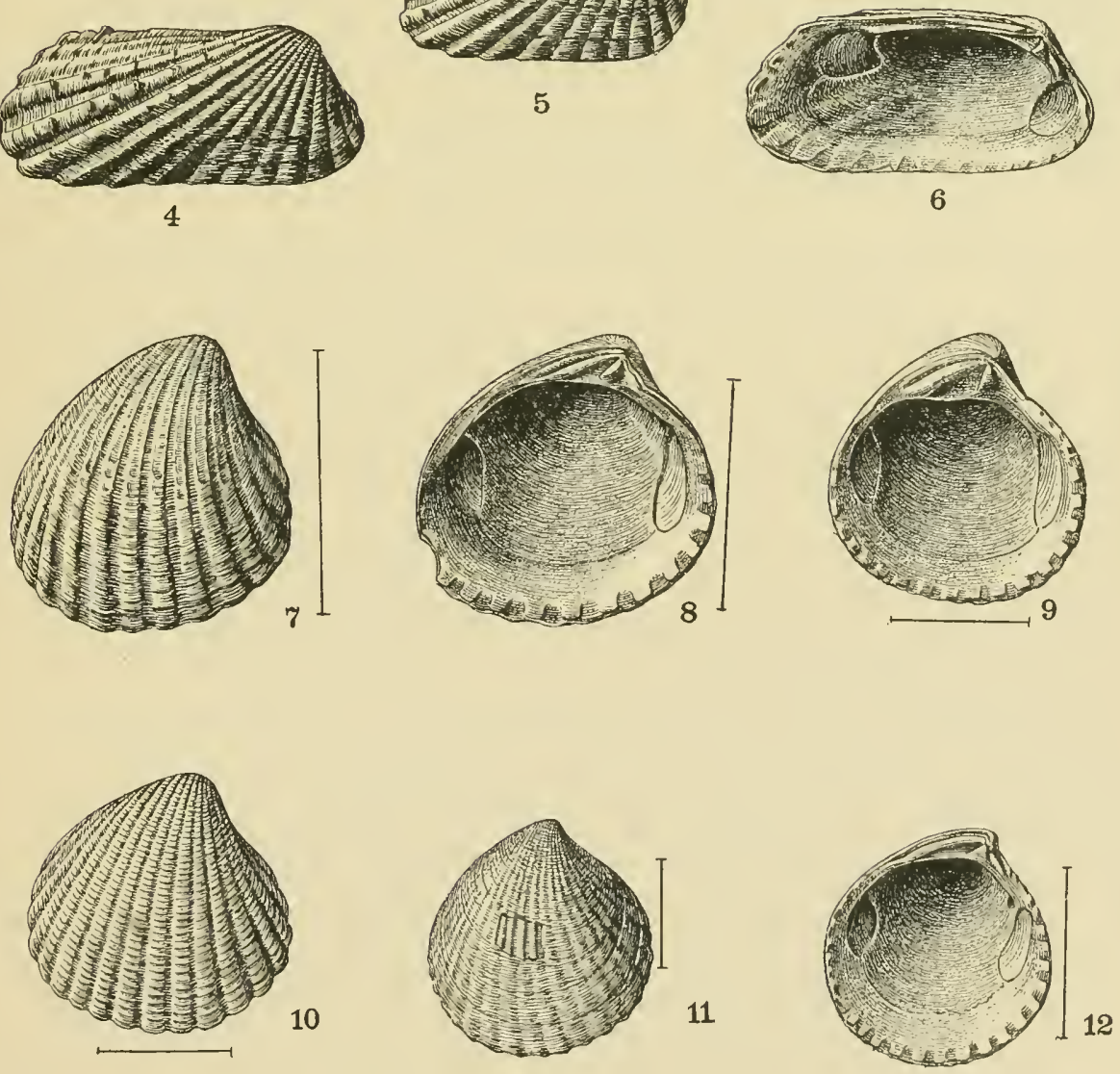

MOLLUSCA-PELECYPODA. 
PLATE XCII.

Figs. 1, 2. Crassatellites melinus (Conrad)

1. Exterior of left valve. Plum Point.

2. Interior of left valve. Same locality. $\quad \times 8 / 9$

Figs. 3-5. Crassatellites turgidulus (Conrad)

3. Exterior of left valve. Jones Wharf.

4. Exterior of left valve of young. Same locality.

5. Interior of left valve. Same locality. 


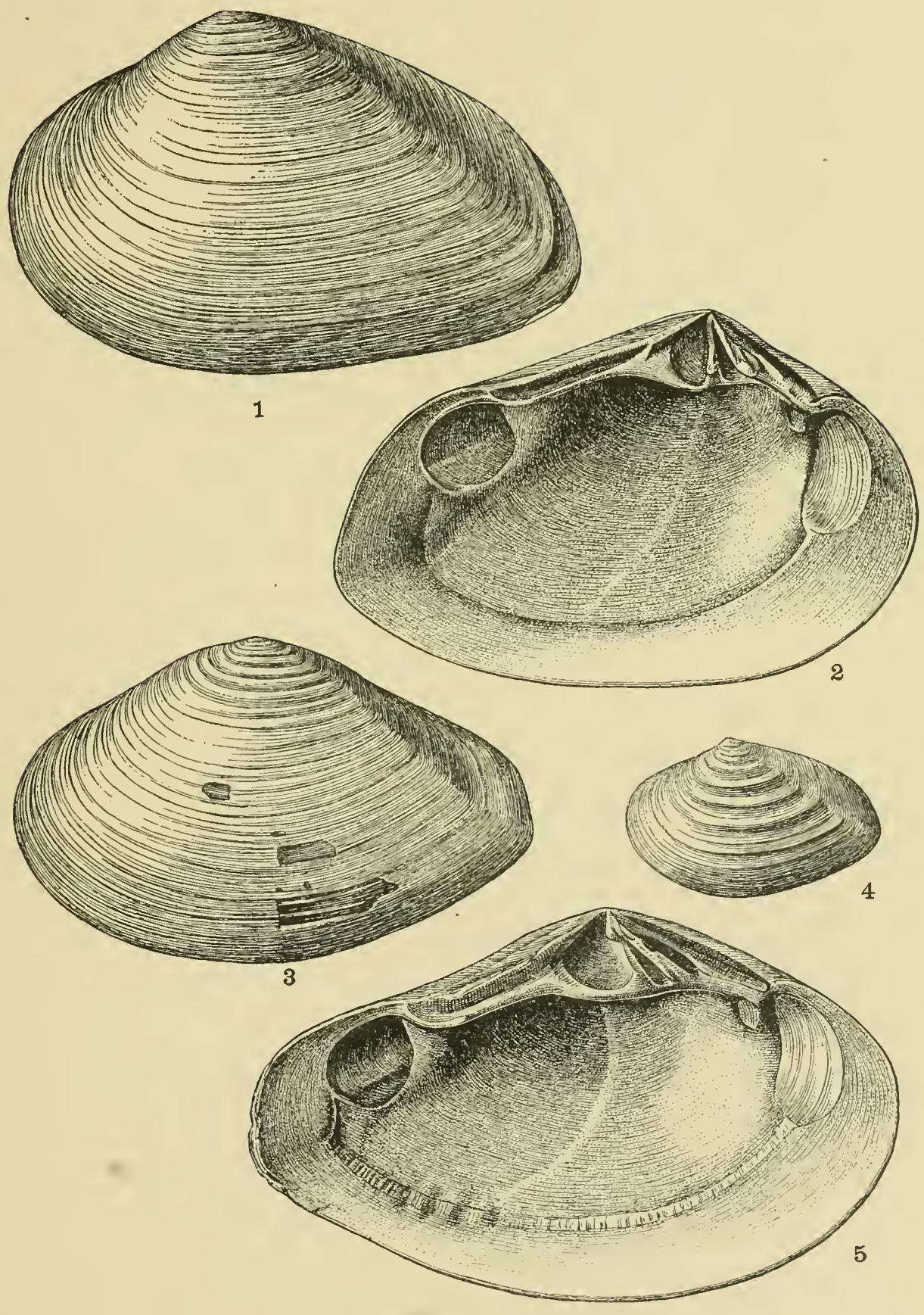




\section{PLATE XCIII.}

PAGE

Figs. 1-3. Crassatellites marylandicus (Conrad) .............. 347

1. Exterior of left valve. Dover Bridge.

2. Exterior of left valve of young individual.

3. Interior of left valve. Same locality.

Figs. 4-6. Astarte cuneiformis Conrad

4. Exterior of right valve. Plum Point.

5. Exterior of right valve. Same locality.

6. Interior of left valve. Same locality.

Figs. 7-9. Astarte castrana n. sp.

7. Interior of right valve. Reed's.

S. Exterior of right valve. Same locality.

9. Exterior of left valve. Same locality.

Figs. 10, 11. Astarte vicina Say

10. Exterior of right valve. Plum Point.

11. Interior of left valve. Same locality. 

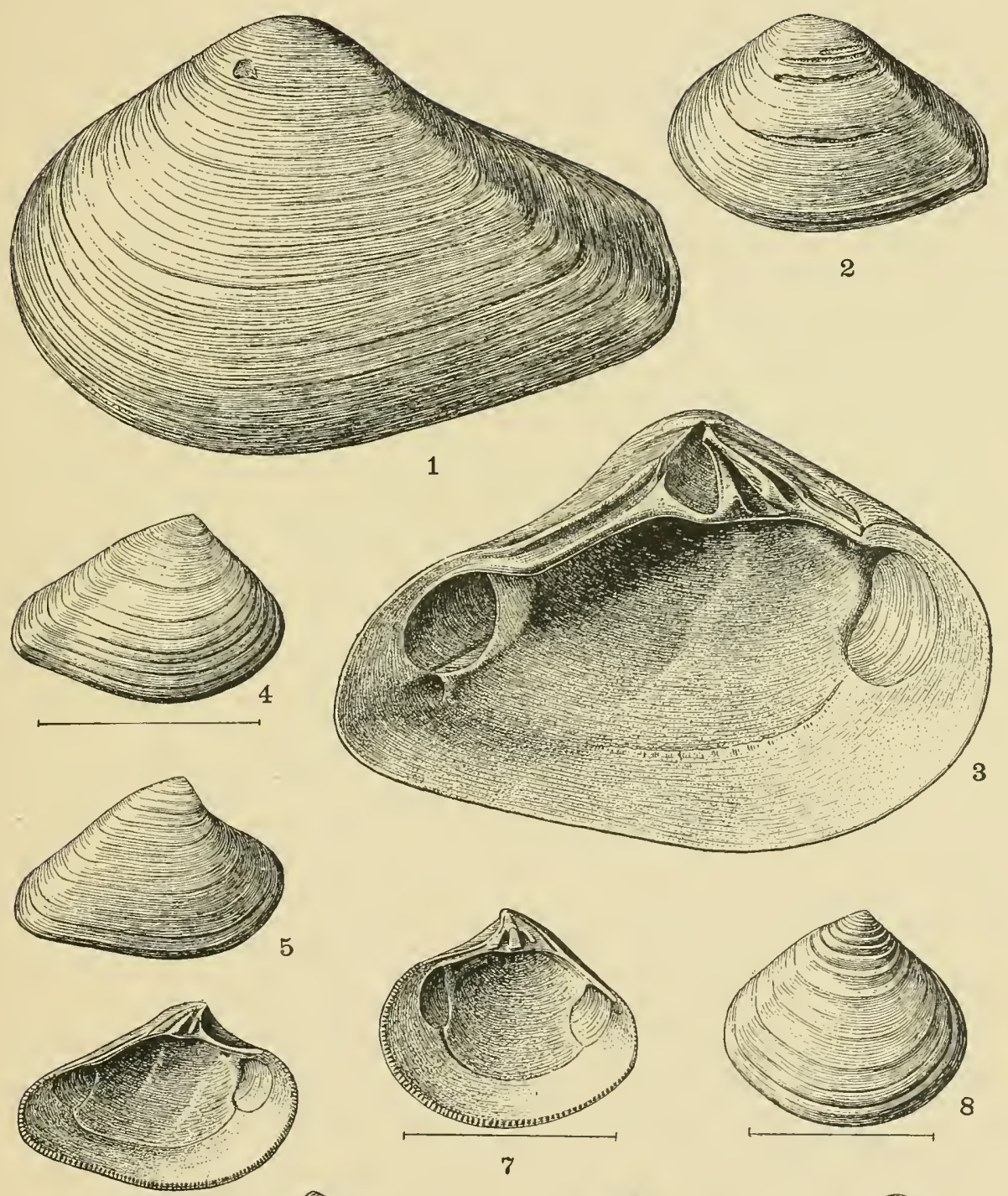

7

6
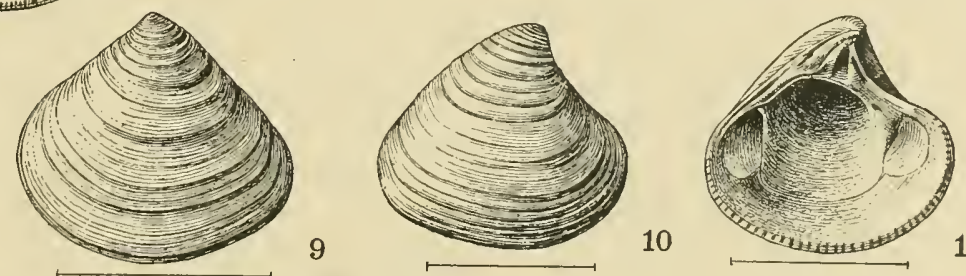

MOLLUSCA-PELECYPODA. 


\section{PLATE XCIV}

Figs. 1, 2. Astarte thomasil Conrad

1. Exterior of right valve. Plum Point.

2. Interior of left valve. Same locality.

Figs. 3, 4. Astarte calvertensis n. sp. .................. 352

3. Exterior of left valve. Plum Point.

4. Interior of right valve. Same locality.

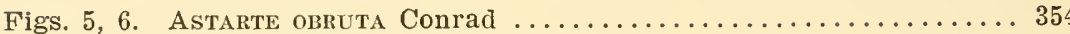

5. Interior of left valve. Dover Bridge.

6. Exterior of left valve. Same locality.

Figs. 7-9, Astarte thispinlla n. sp.

7. Interior of right valve. Jones Wharf.

8. Exterior of right valve. Same locality.

9. Exterior of left valve-the most characteristic drawing. Same locality.

Figs. 10, 11. Astarte Perplana Conrad ............................. 356

10. Interior of left valve. St. Mary's River.

11. Exterior of right valve. Same locality.

Fig. 12. Crassatellites (Crassinella) duplinianus Dall .......... 349

12. Exterior of right valve of type specimen. Duplin county, North Carolina. U. S. National Museum.

Figs. 13, 14. Crassatellites (Crassinella) galvestonensis (Harris) .. 350

13. Exterior of right valve. St. Mary's River.

14. Interior of left valve. Same locality.

Fig. 15. Astarte parma Dall

15. Exterior of left valve. (After Dall.) $\times 4 / 5$ 
000

0.0

0.0.

0.0 
PLATE XCV.

Figs, 1, 2. Pandora (Clidiophora) Crassidens Conrad

1. Exterior of left valve. St. Mary's River.

2. Interior of right valve. Same locality.

Fig. 3. Periploma peralta Conrad

3. Interior of broken valve. Cove Point.

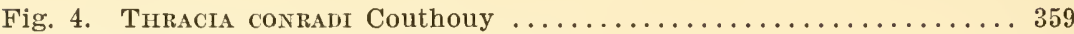

4. Exterior of left valve. Plum Point.

Figs. 5, 6. Margaritaria abrupta (Conrad)................... 361

5. Exterior of right valve. Yorktown, Virginia.

6. Interior of left valve. Same locality.

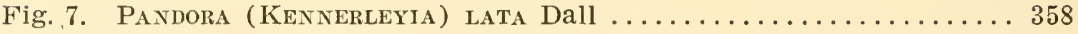

7. Exterior of left valve. St. Mary's River (?). U. S. National Museum. (After Dall.)

Fig. 8. Divaricella quadrisulcata (d'Orbigny)

8. Exterior. Petersburg, Va. U. S. National Museum. (After Dall.) $\times 1 \frac{1}{2}$ 


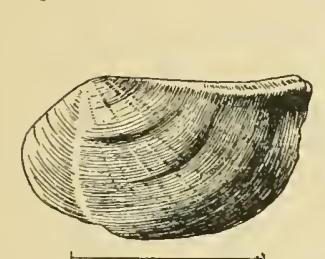

1

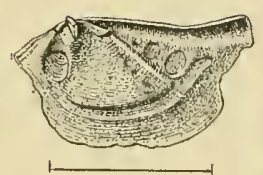

2
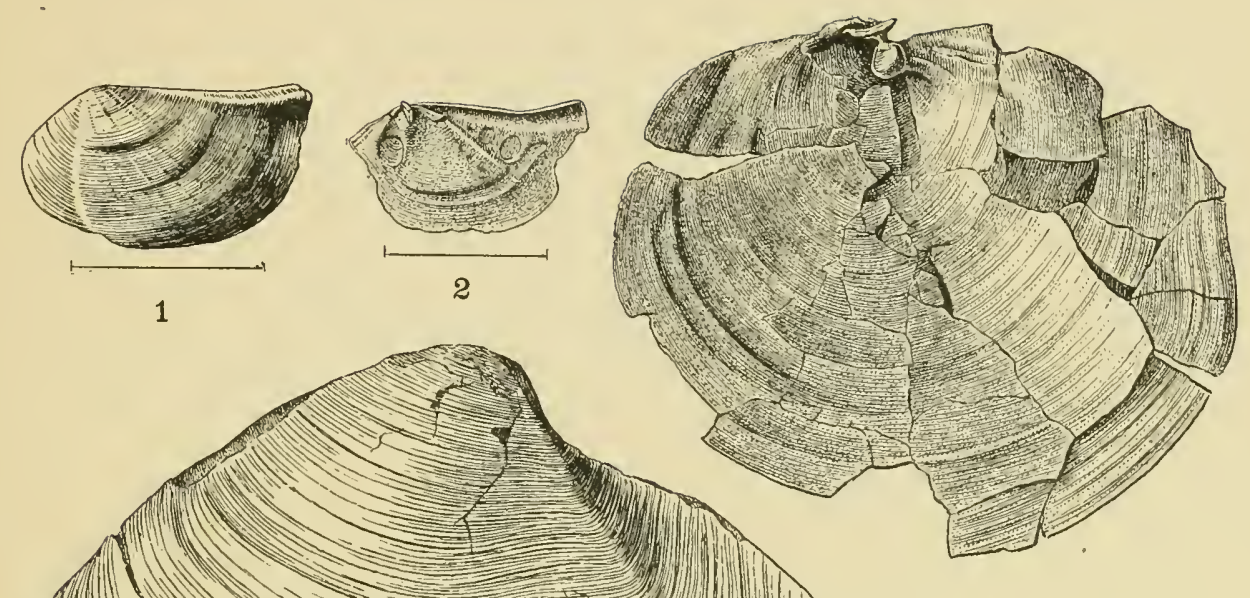

3
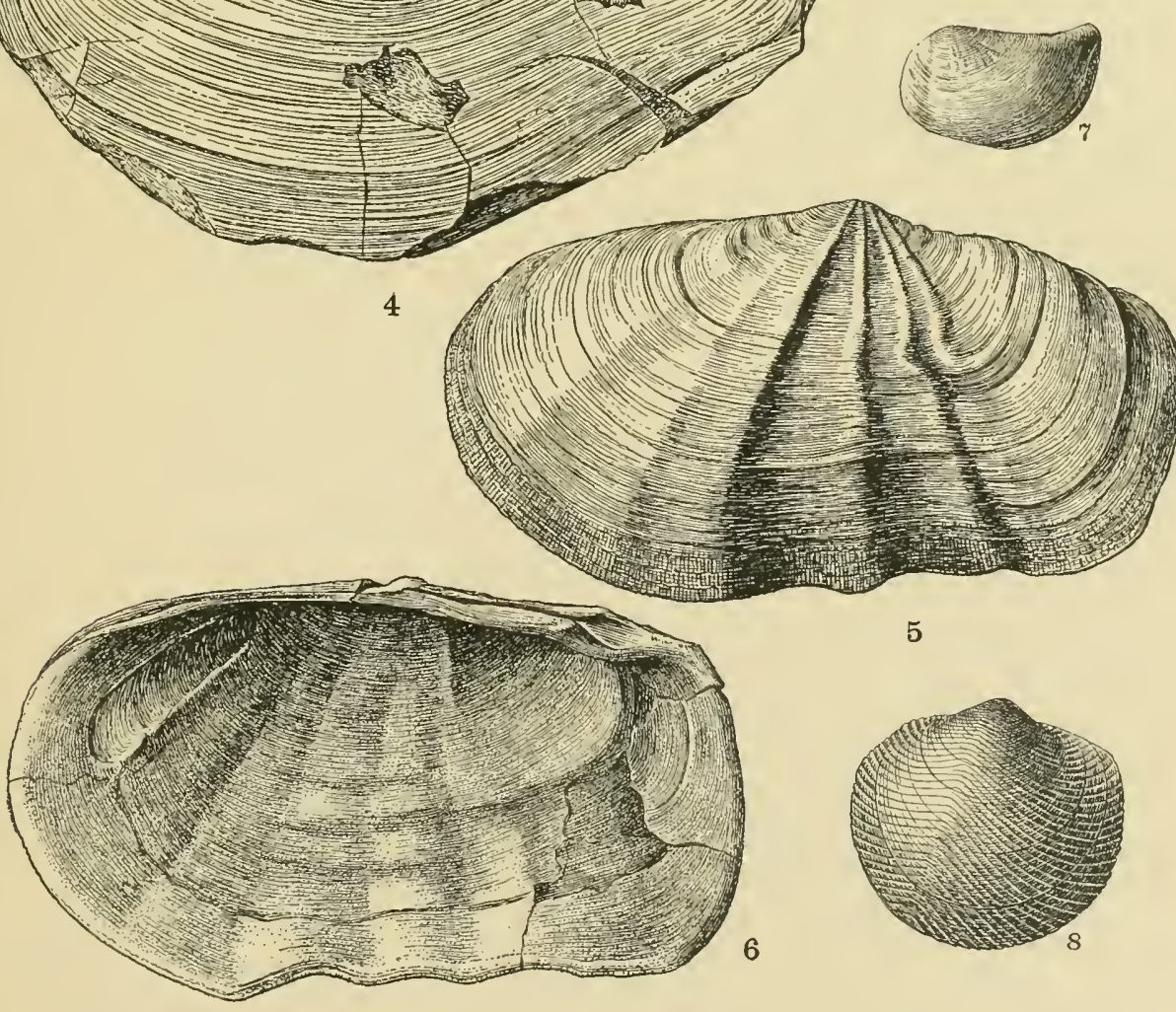

4

5

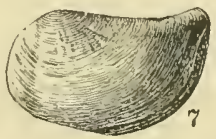

\section{5}

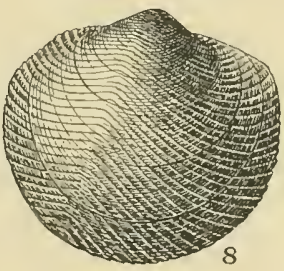




\section{PLATE XCVI.}

Figs. 1a, 1b. Mytilus conradinus d'Orbigny ........................ 362

1a. Exterior of right valve. Plum Point. $\times 1 / 2$.

1b. Interior of same valve.

Figs. 2-4. Mrtilus (Mrtiloconchi) incunvus Conrad............. 363

2. Exterior of right valve with part of beak of left valve showing beneath. Greensboro. $\times 2 / 3$

3. Interior of right beak. Same locality.

4. Interior of left beak. Same locality. 


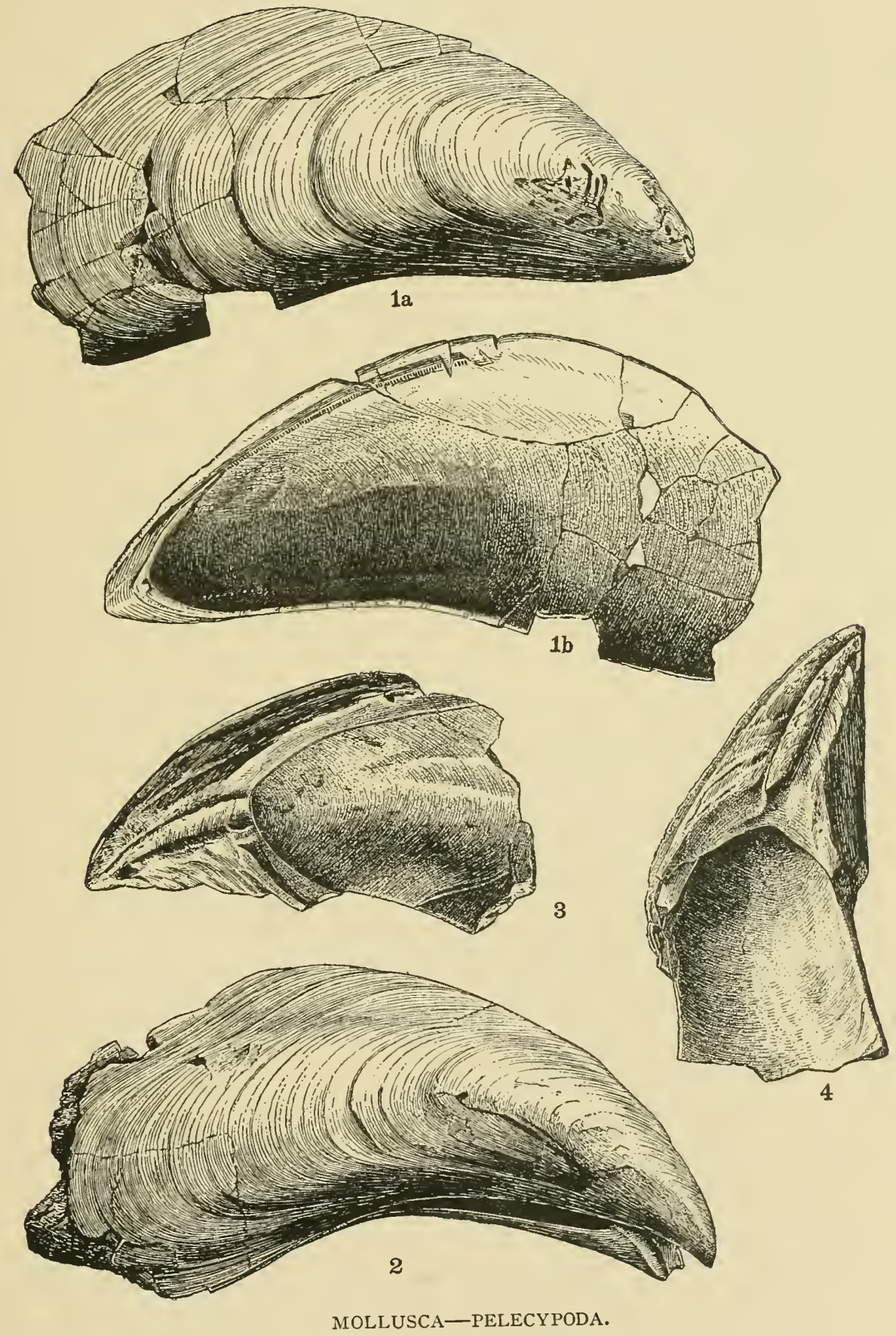




\section{PLATE XCVII.}

Fig. 1. Lithophaga subalveata Conrad

1. Exterior of right valve. Shiloh, New Jersey. Acad. Nat. Sci., Phila. (After Conrad. Amer. Jour. Conch., vol. II, pl. IV, fig. IV.)

Fig. 2, 3. Lithophaga ionensis n. sp.

2. Exterior of right valve. Jones Wharf.

3. Exterior of right valve. Same locality.

Fig. 4. Crenella virida n. sp. 365

4. Specimen from Greensboro.

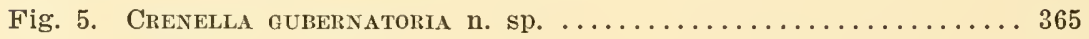
5. Specimen from Governor Run.

Figs. 6, 7. Modolus ducatellii Conrad . . 366

6. Exterior of right valve. Dover Bridge.

7. Interior of beak portion of left valve. Cove Point.

Figs. 8a, 8b. Modiolus virginicus (Conrad) $\ldots \ldots \ldots \ldots \ldots \ldots \ldots \ldots$

8a. Exterior of left valve. St. Mary's River.

$8 \mathrm{~b}$. Interior of same specimen.

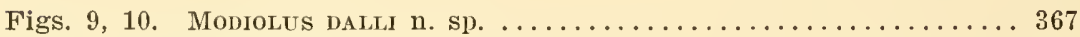

9. Interior of right valve. Pawpaw Point.

10. Exterior of left valve of same individual.

Figs. 11, 12. Modiolus IONENSIS n. sp.

11. Exterior of right valve. Jones Wharf.

12. Interior of left valve of same individual.

Fig. 13. Modolaria curta n. sp.

13. Exterior of right valve. Plum Point. Cornell University. 

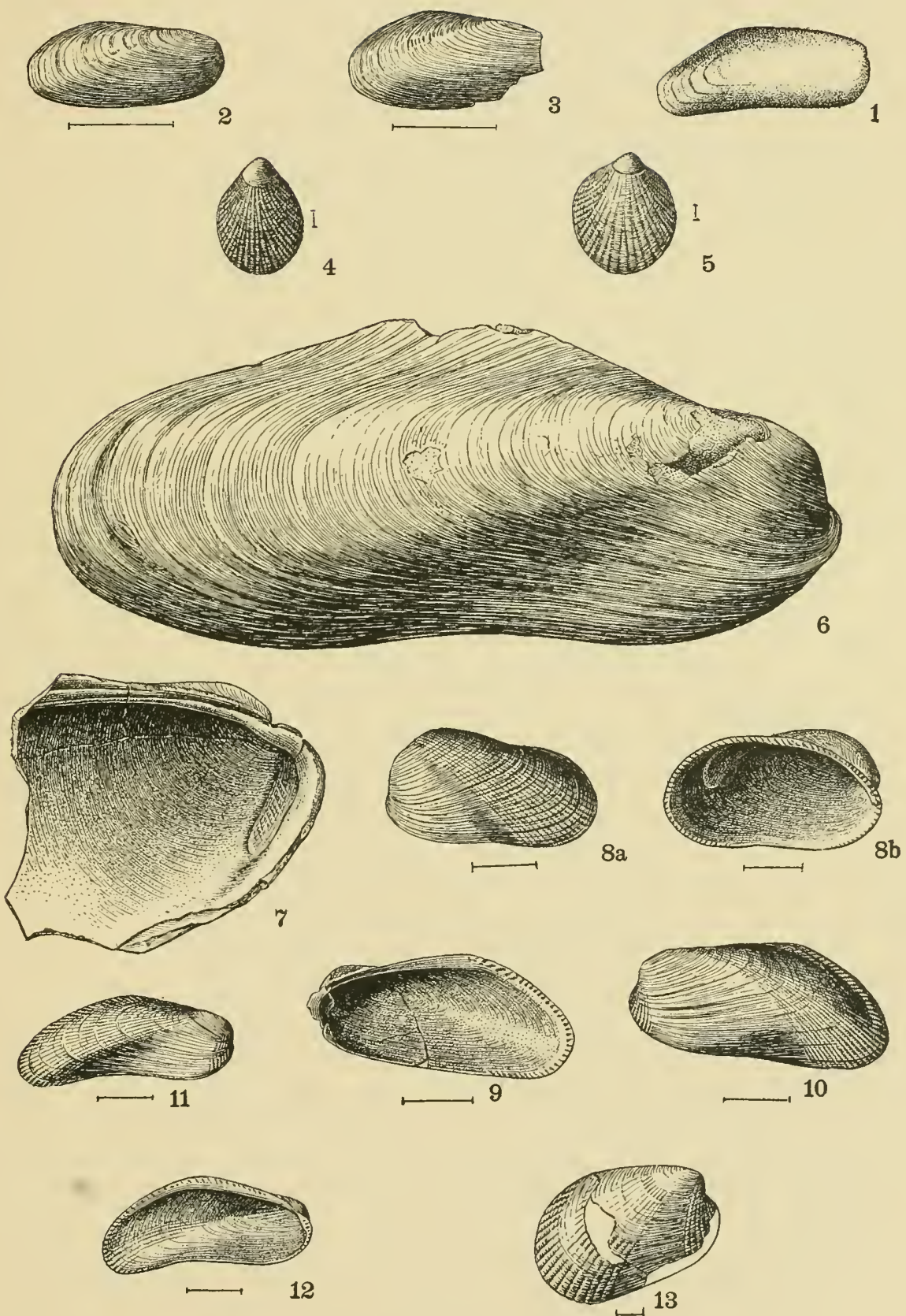

MOLLUSCA-PELECYPODA. 
PLATE XCVIII.

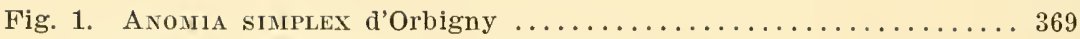

1. Exterior of upper valve. St. Mary's River.

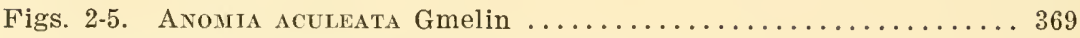

2. Exterior of broken upper valve. Plum Point.

3. Exterior of lower valve. Jones Wharf.

4. Interior of lower valve. Same locality.

5. Exterior of lower valve. Same locality.

Fig. 6. LIMA PAPYria Conrad ........................... 370

6. Exterior of right valve. Plum Point.

Figs. 7-9. Plicatula densata Conrad ..................... 371

7. Interior of lower valve. Evans farm near Church Hill.

8. Exterior of upper valve. Same locality.

9. Exterior of upper valve. Same locality.

Figs. 10-12. Pecten (Pecten) humpinexsir Conrad ............. 372

10. Exterior of lower valve. Plum Point. $\times 1 / 2$.

11. Exterior of another lower valve. Same locality.

12. Exterior of an upper valve. Same locality. 


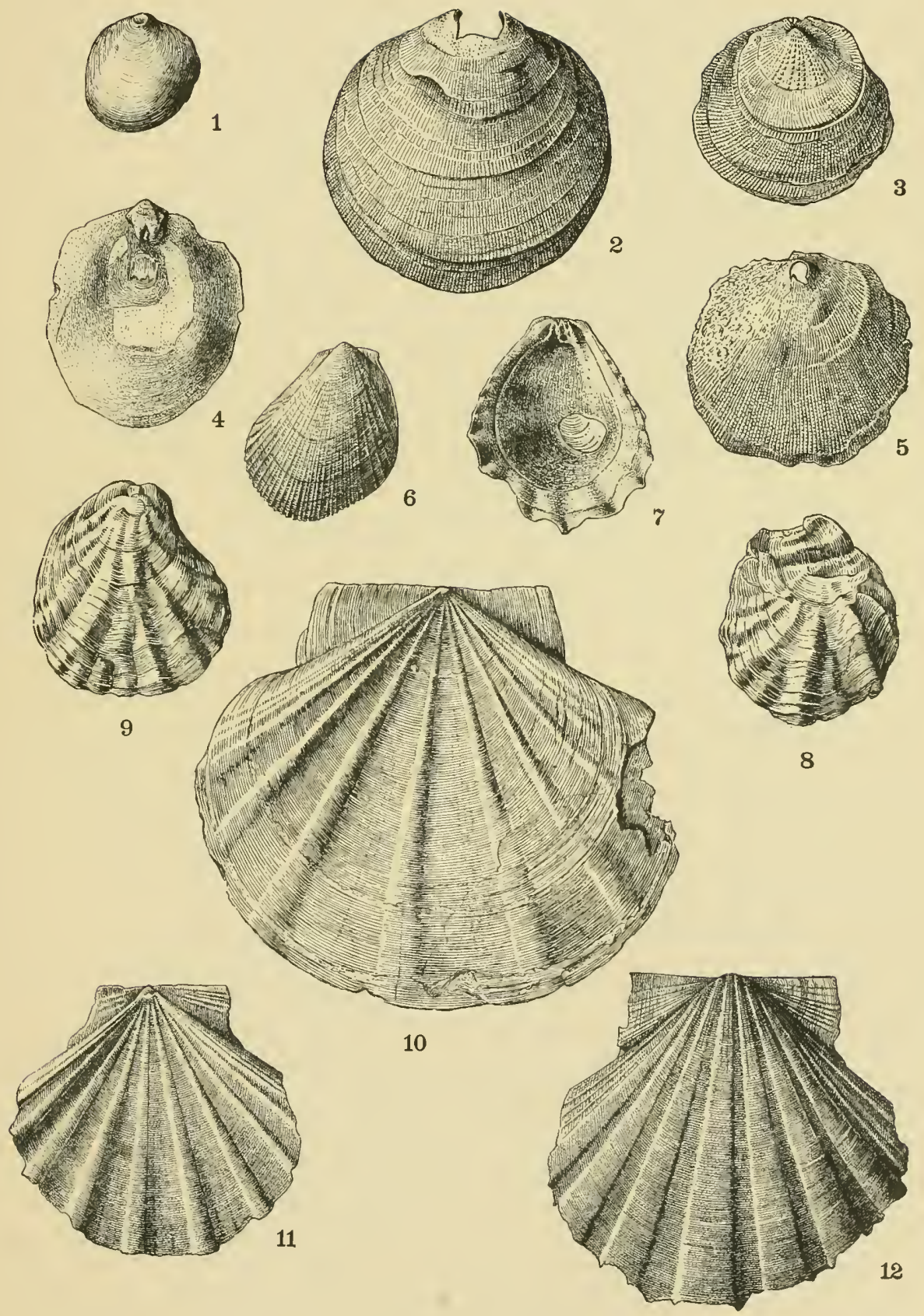




\section{PLATE XCIX.}

PAGE

Fig. 1. Pecten (Amusiuni) mortoni Ravenel ................. 372

1. Exterior of right valve. Fort Thompson, Florida. U. S. National Museum. $\times 1 / 2$

Fig. 2. Pecten (Pseudanusium ) cerixus Conrad ................. 373

2. Exterior of right valve. Plum Point.

Fig. 3. Pecten (Chllaiys) coccymelus Dall ................. 374

3. Exterior of left valve. Plum Point. (After Dall.)

Fig. 4. Pecten (Chlanys) rogersi Conrad . ................... 375

4. Exterior of right valve. Near Skipton. U. S. National Museum.

Fig. 5. Pecten (Chlamys) clintonius Say .................. 375

5. Exterior of right valve. James River, Virginia. $\times 1 / 2$

Fig. 6. Pecten (Chlairys) marylanuicus Wagner............. 376

6. Exterior of left valve. Jones Wharf. 

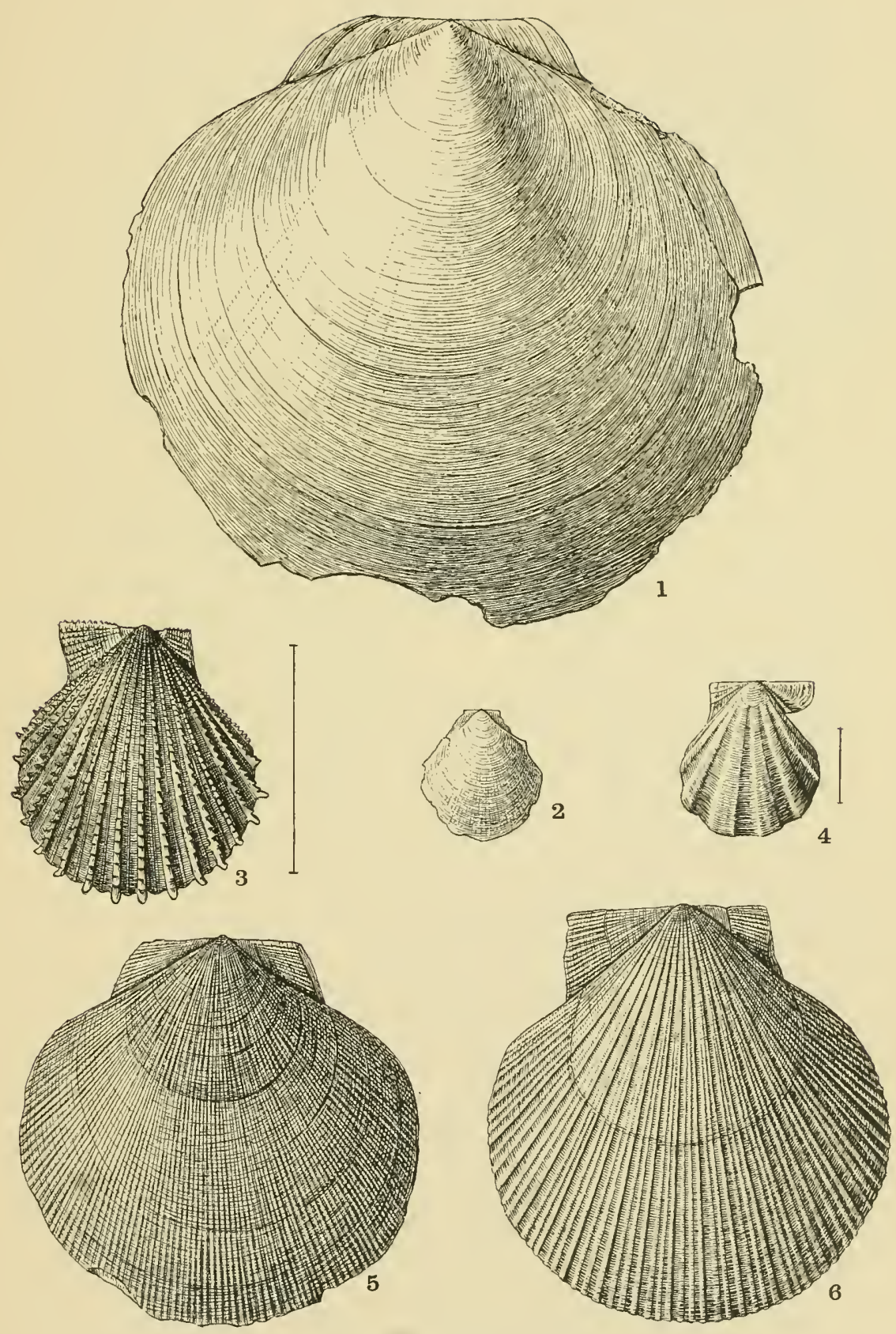

MOLLUSCA-PELECY PODA. 
PLATE C.

Fig. 1. Pecten (Chlamys) madisonius Say .................... 377

1. Exterior of left valve. Flag Pond. $\quad \times 1 / 2$

Fig. 2. Pecten (Chlamys) Jeffersonius Say ................ 378

2. Exterior of right valve. St. Mary's River. $\quad \times 1 / 2$

Fig. 3. Pecten Jeffersonius var. edgecombensis Dall .............. 379

3. Exterior of left valve. St. Mary's River. U. S. National Museum. $\quad \times 1 / 2$

Fig. 4. Pecten Jeffersonius var. Septenarius Say .............. 379

4. Exterior of right valve. Petersburg, Virginia. U. S. National Museum. $\times 1 / 2$

Figs. 5a, 5b. Ostrea sell mFormis var. Thomasil (Conrad) ......... 380

5a. Exterior of type specimen. Charles county near the Patuxent river. Acad. Nat. Sci., Phila.

5b. Interior of the same specimen. 

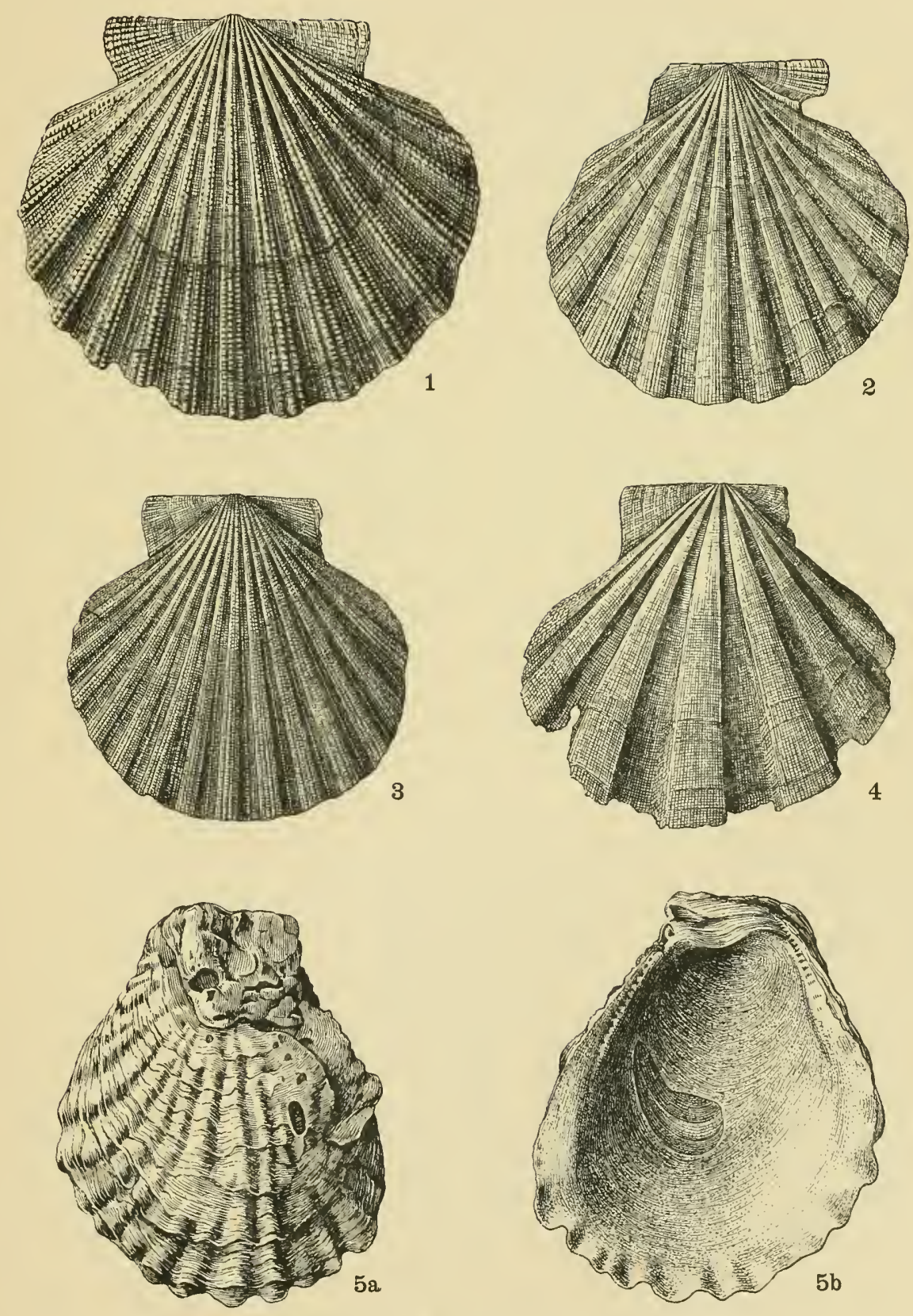


\section{PLATE CI}

Figs. 1a, 1b. Ostrea trigoxalis Conrad ...................... 381

1a. Exterior of lower valve. Greensboro. $\times 2 / 3$

1b. Interior of the same valve. $\quad \times 2 / 3$

Figs. 2-4. Ostrea CARolinensis Conrad

2. Interior of lower valve. Governor Run. $\times 2 / 3$

3. Interior of upper valve. Same locality. $\quad \times 2 / 3$

4. Exterior of lower valve. Same locality. $\quad \times 2 / 3$ 


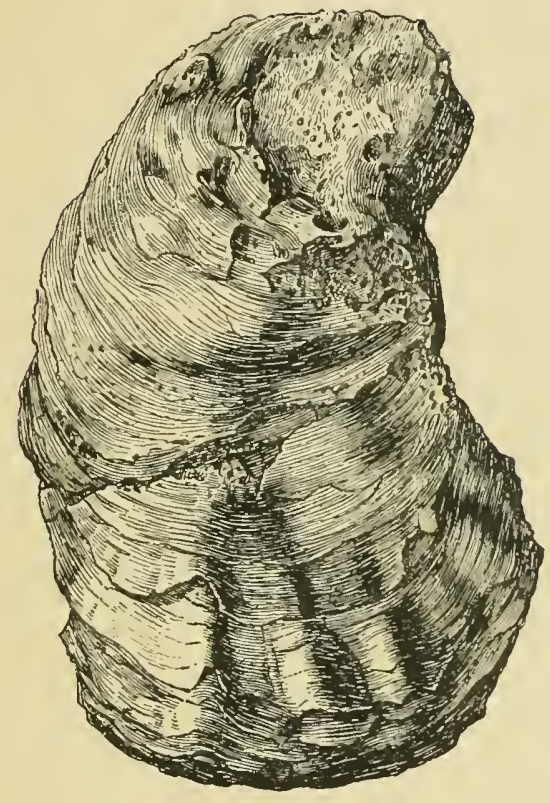

1a

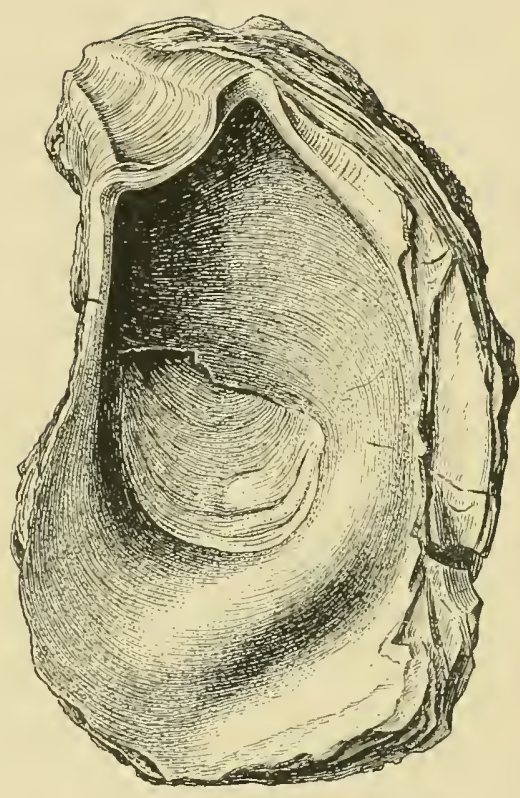

$1 \mathrm{~b}$

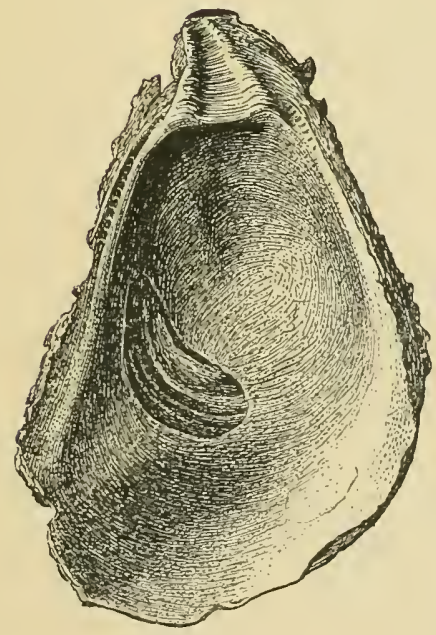

2

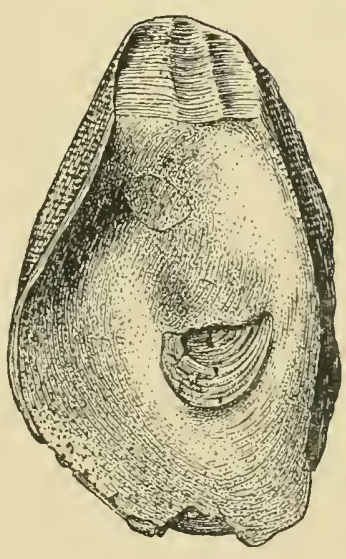

3

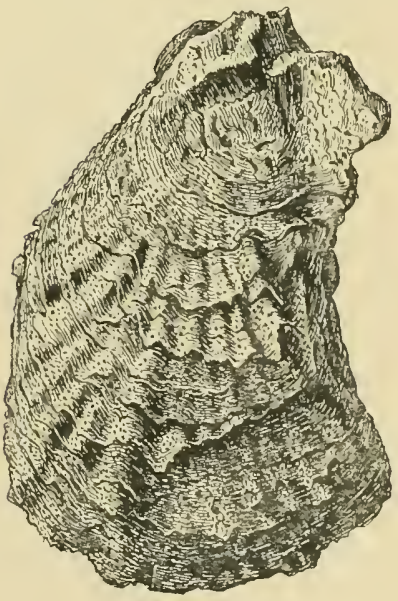

4

MOLLUSCA-PELECY PODA. 


\section{PLATE CII.}

Figs. 1, 2. Ostrea percrassa Conrad .................... 382

1. Exterior of upper valve. Magruder Ferry. $\quad \times 1 / 2$

2. Interior of lower valve. Same locality. $\quad \times 1 / 2$

Fig. 3. Melina maxillata (Deshayes) ................... 383

3. Exterior of right valve. Plum Point. $\quad \times 2 / 3$ 


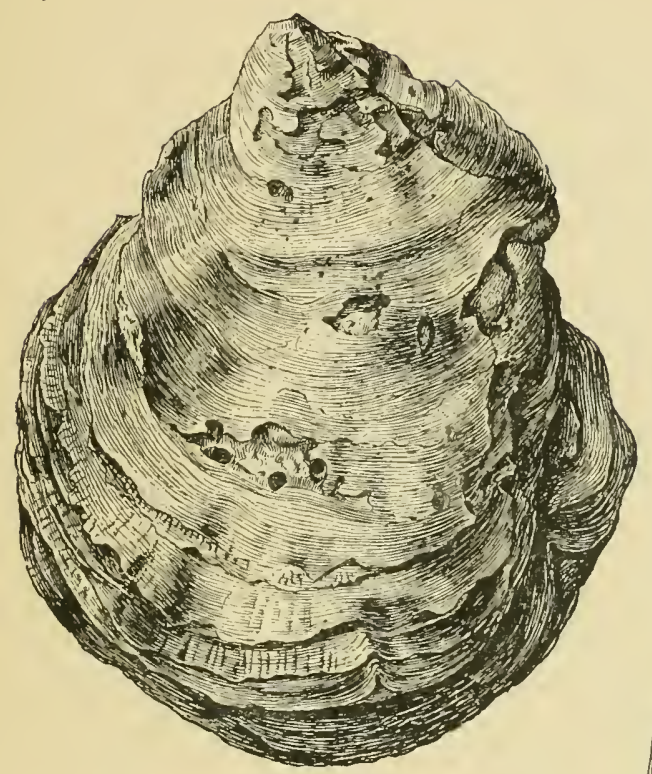

1
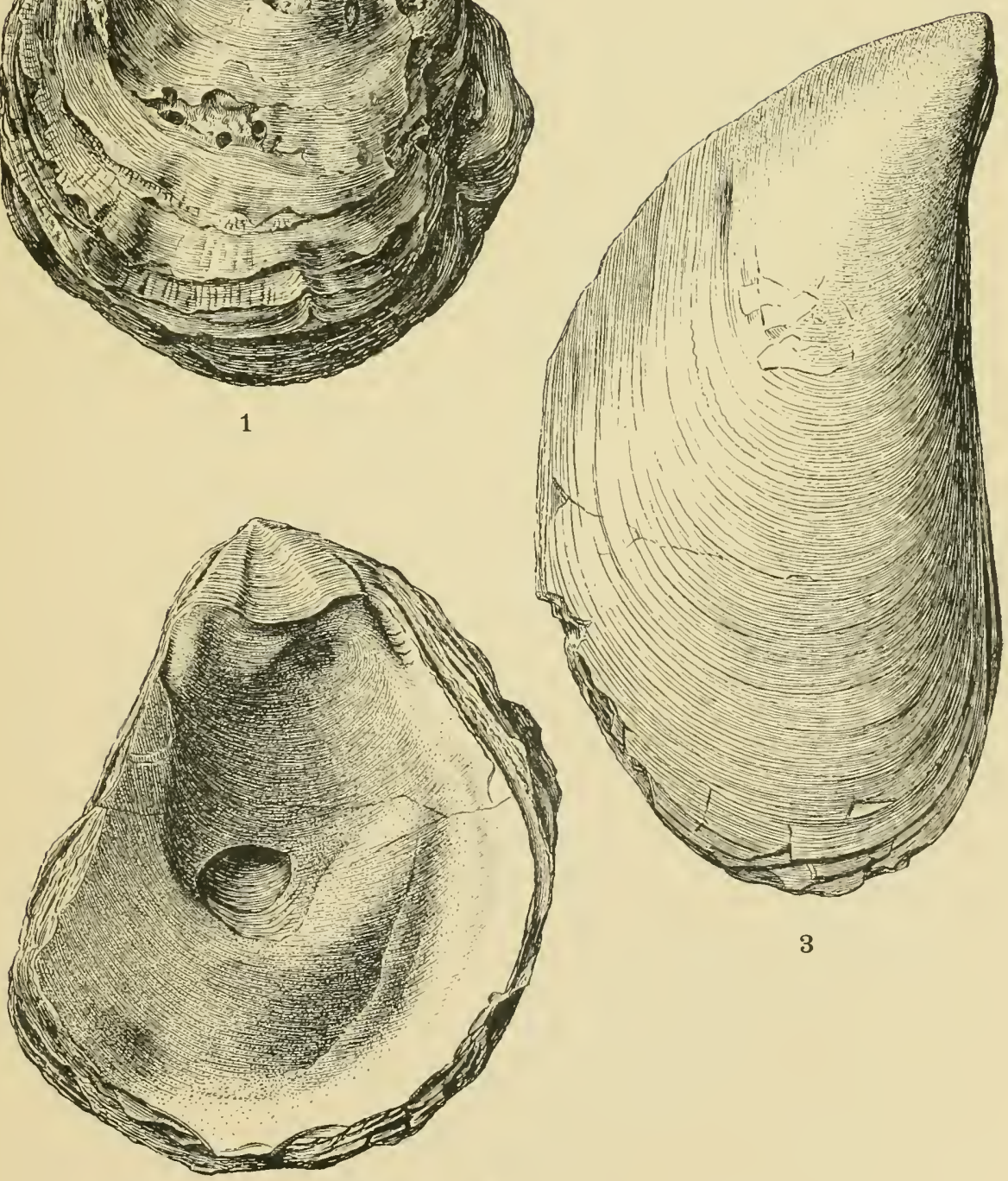


\section{PLATE CIII.}

Fig. 1. Melina maxillata (Deshayes) $\ldots \ldots \ldots \ldots \ldots \ldots \ldots \ldots \ldots \ldots \ldots \ldots \ldots \ldots \ldots \ldots$

1. Interior of broken valve showing hinge and ligament grooves. Jones Wharf. $\times 2 / 3$

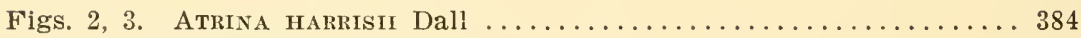

2. Exterior of right valve. Pawpaw Point. $\quad \times 2 / 3$

3. Exterior of decorticated right valve. Jones Wharf. U. S. National Museum. (After Dall.) $\times 2 / 3$ 


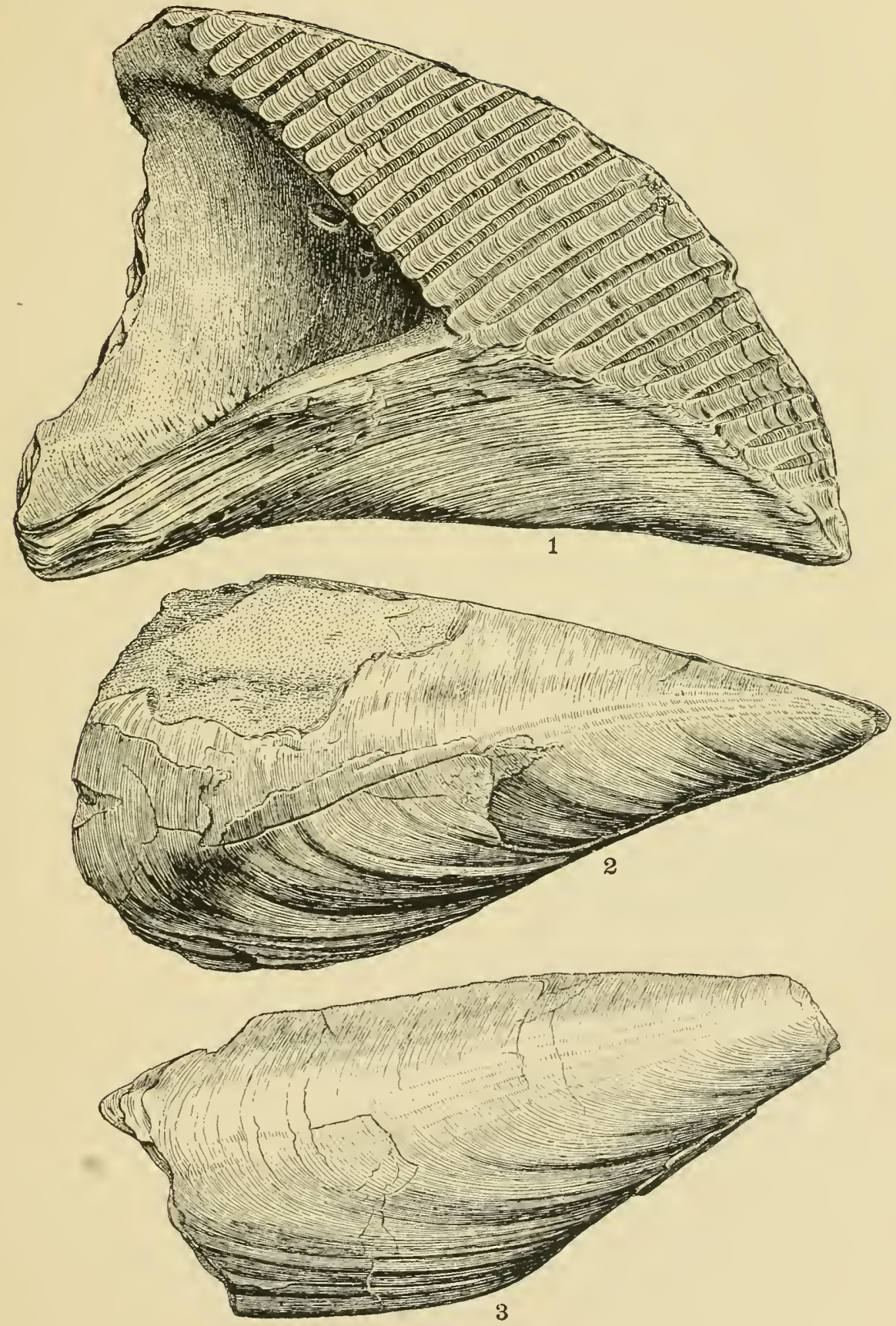




\section{PLATE CIV.}

Fig. 1. Atrina piscatoria n. sp

1. Exterior of right valve. Fishing Creek. $\times 2 / 3$

Figs. 2-3b. Arca (Scapharca) subrostrata Conrad

2. Interior of right valve. Plum Point,

3a. Exterior of right valve. Same locality.

3b. Exterior of right valve. Same locality.

Figs. 4a, 4b. Arca (ScapiIARCA) Elvid n. sp. 386

4a. Exterior of right valve. Jones Wharf.

4b. Interior of right valve. Same locality. 

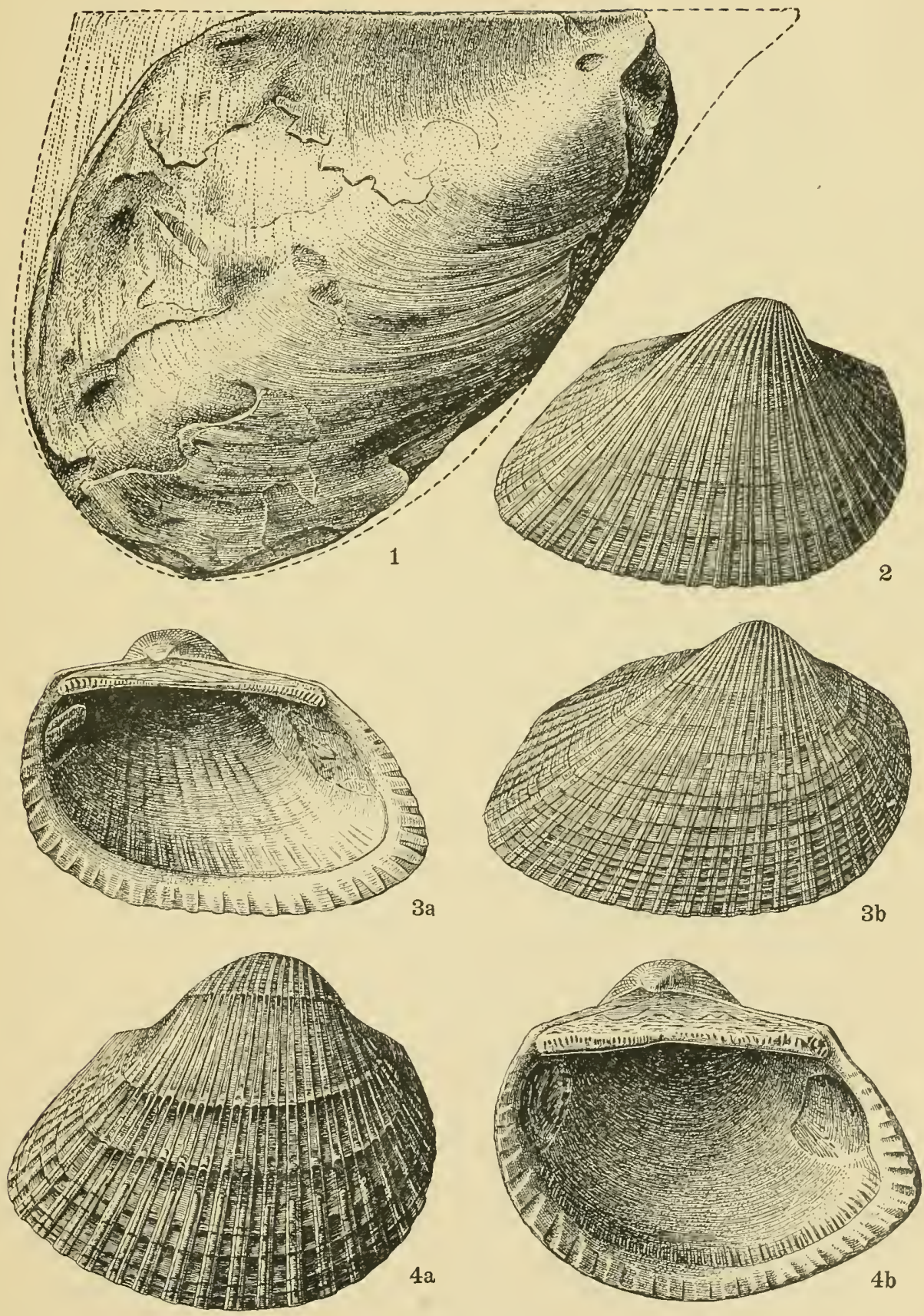


\section{PLATE CV.}

Fig. 1. Arca (Scapilarca) clisia Dall

1. Interior of left valve. Nomini Cliffs, Virginia. U. S. National Museum. $56 \mathrm{~mm}$. (After Dall.)

Figs. 2-6. Arca (Scarifarca) staminea Say .

2. Interior of left valve. Flag Pond.

3. Interior of left valve of short variety. Same locality.

4. Exterior of right valve. Same locality.

5. Exterior of right valve. Dover Bridge.

6. Interior of left valve. Peach Blossom Creek.

Figs. 7a, 7b. Arca (Scapharca) arata Say.

7a. Interior of right valve. St. Mary's River.

$7 \mathrm{~b}$. Exterior of left valve. Same locality. 

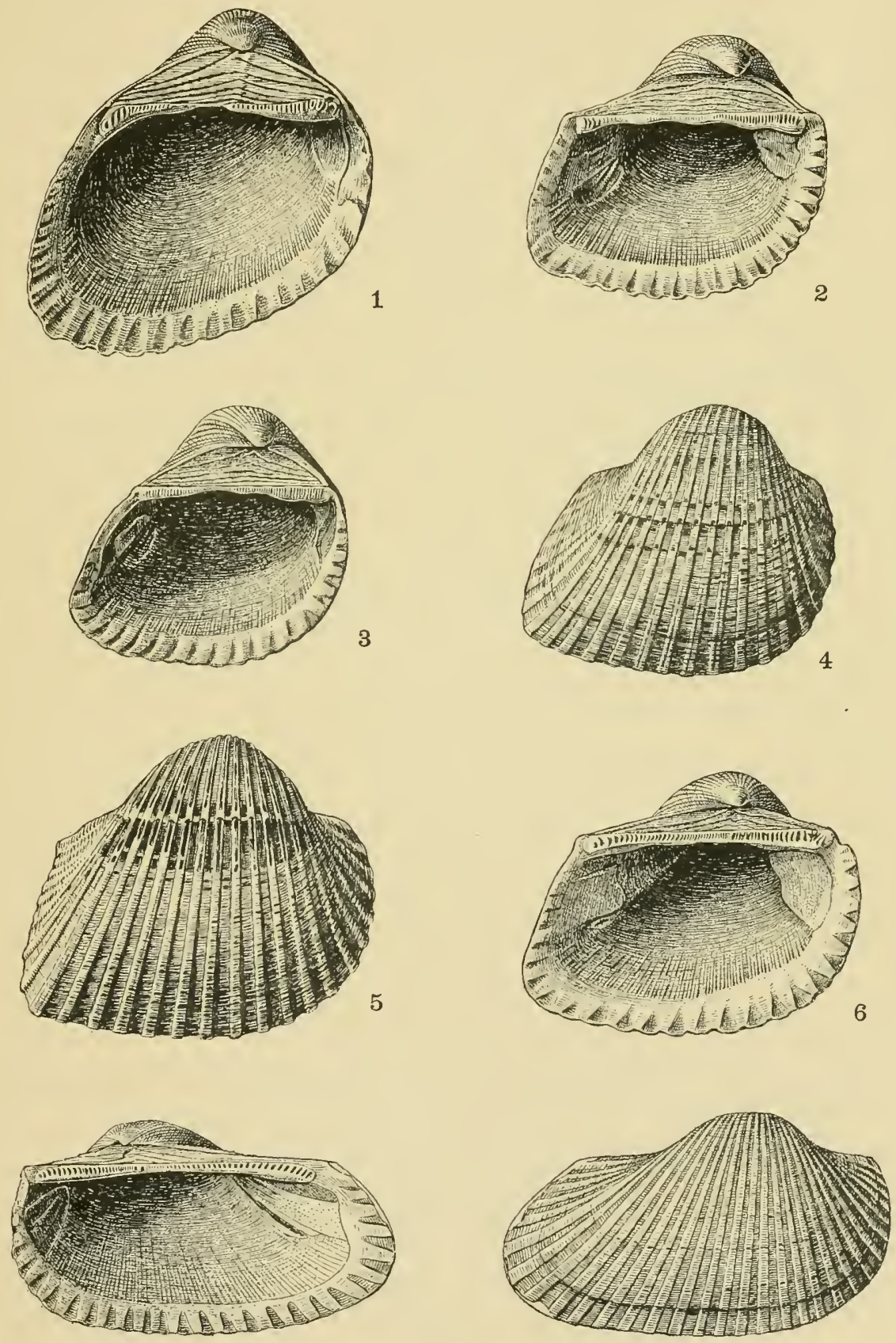

$7 \mathrm{a}$ 


\section{PLATE CVI.}

Figs. 1, 2. Arca (Scapharca) idonea Conrad

1. Interior of left valve. St. Mary's River.

2. Exterior of right valve. Same locality.

Figs. 3, 4. Arca (Nö̈tia) incile Say ....................... 390

3. Exterior of right valve. Darlington, South Carolina. Johns Hopkins University.

4. Interior of left valve. Same locality.

Figs. 5, 6. Arca (Barbatia) centenaria Say.

5. Interior of right valve. Jones Wharf.

6. Exterior of left valve. Same locality.

Fig. 7. Arca (Barbatia) maryla dica Conrad ........................ 392

7. Exterior of right valve. Plum Point. U. S. National Museum.

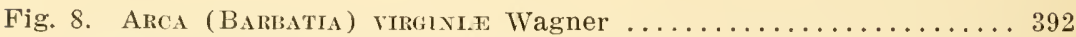

8. Exterior of left valve of type specimen. Miocene of Virginia (Nansemond River?) $84 \mathrm{~mm}$. Wagner Free Inst. Sci. (After Dall.) 

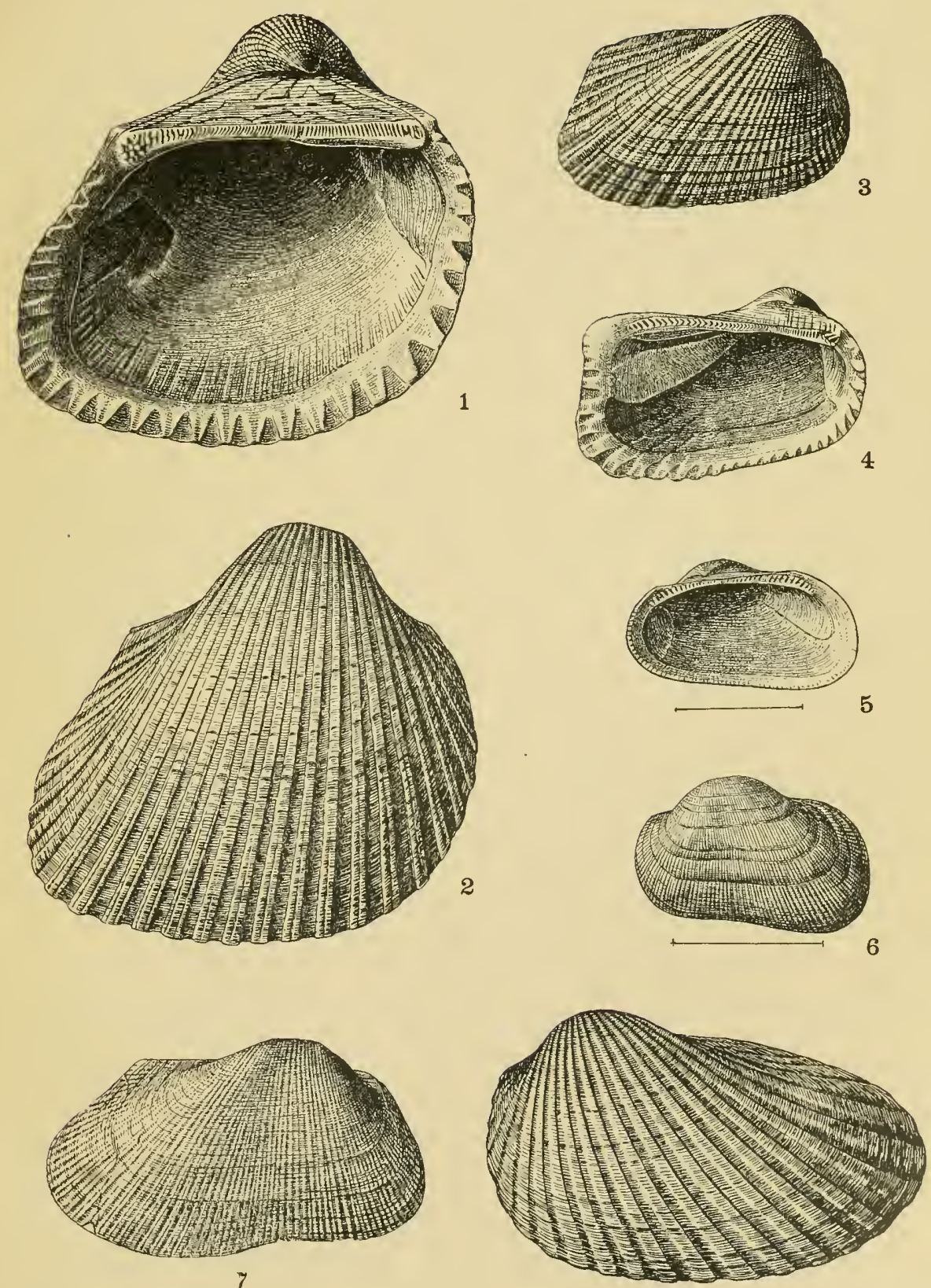


\section{PLATE CVII.}

Figs. 1, 2. GlycyMeris Parilis (Conrad)

1. Interior. 3 miles south of Fishing Creek. $\times 5 / 6$

2. Exterior of opposite valve. Same locality. $\quad \times 5 / 6$

Figs. 3, 4. Glycymeris subovata (Say) .

3. Interior. Greensboro.

4. Exterior. Same locality.

Figs. 5-8. LedA liciata (Conrad).

5. Exterior of left valve with coarse sculpture. Plum Point.

6 . Interior of left valve. Same locality.

7. Exterior of left valve with very fine close-set concentric sculpture. Same locality.

8. Exterior of left valve with very coarse sculpture. Same locality.

Figs. 9, 10. Leda liciata var. Amydra Dall 396

9. Interior of left valve. Plum Point.

10. Exterior of left valve. Same locality. 


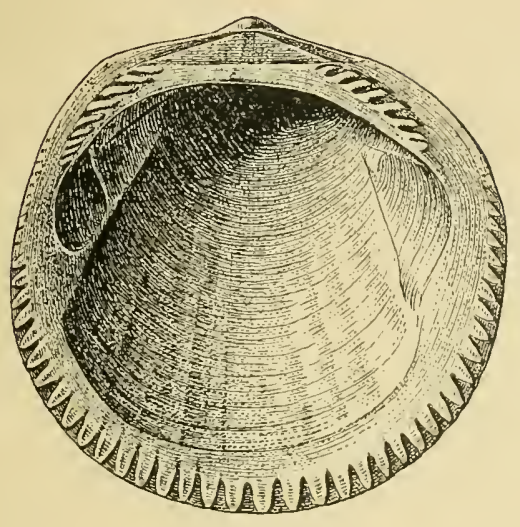

1
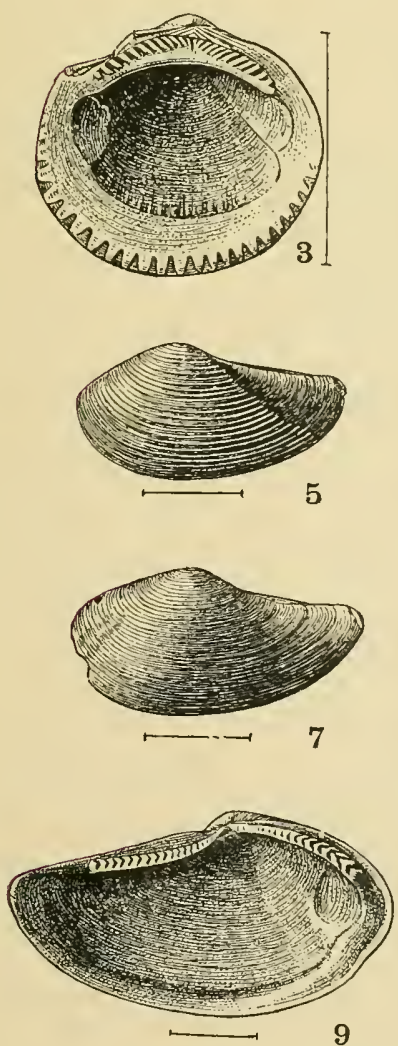

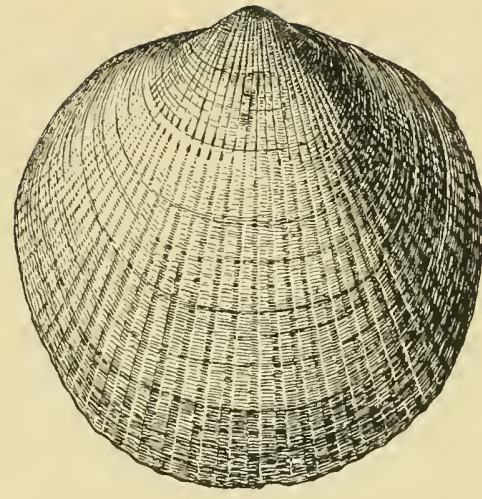

2
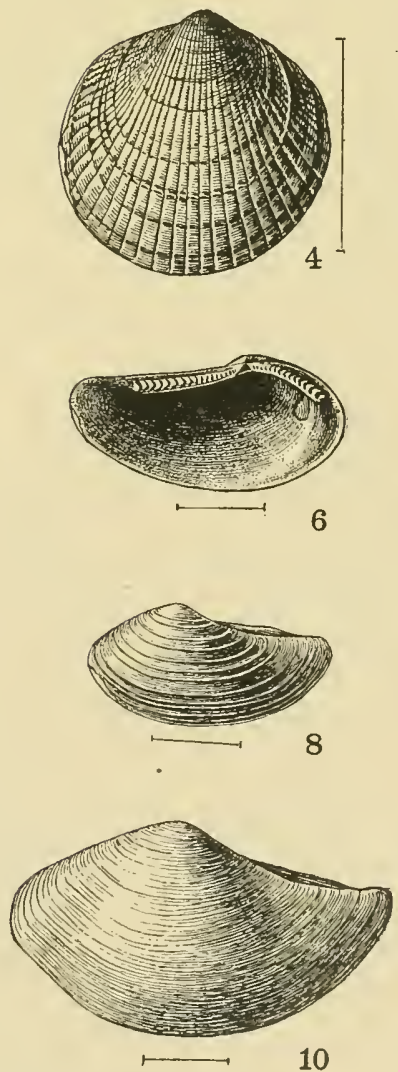

10

MOLLUSCA-PELECYPODA. 


\section{PLATE CVIII.}

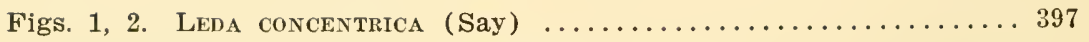

1. Interior of right valve. Pocomoke City Well, 53 to 75 feet from surface.

2. Exterior of right valve. Same locality.

Figs. 3, 4. Yoldia levis (Say) $\ldots \ldots \ldots \ldots \ldots \ldots \ldots \ldots \ldots \ldots \ldots \ldots \ldots \ldots \ldots \ldots \ldots \ldots \ldots$

3. Interior of right valve. Jones Wharf.

4. Exterior of left valve. Same locality.

Figs. 5, 6. Nucula proxima Say .................................. 398

5. Exterior of right valve. Dover Bridge.

6. Interior of left valve. Same locality.

Figs. 7, 8. Nucula sinaria Dall ............................ 399

7. Interior of left valve. Cove Point.

8. Exterior of right valve. Same locality.

Figs. 9-11. Nucula tapiria Dall .................... 400

9. Interior of right valve. St. Mary's River.

10. Exterior of right valve from Natural Well, North Carolina. U. S. National Museum. (After Dall.)

11. Exterior of right valve. St. Mary's River.

Figs. 12-14. Nucula prunicola Dall .................... 401

12. Exterior of right valve. Plum Point.

13. Exterior of right valve. Same locality. U. S. National Museum. (After Dall.)

14. Interior of right valve. Same locality. 

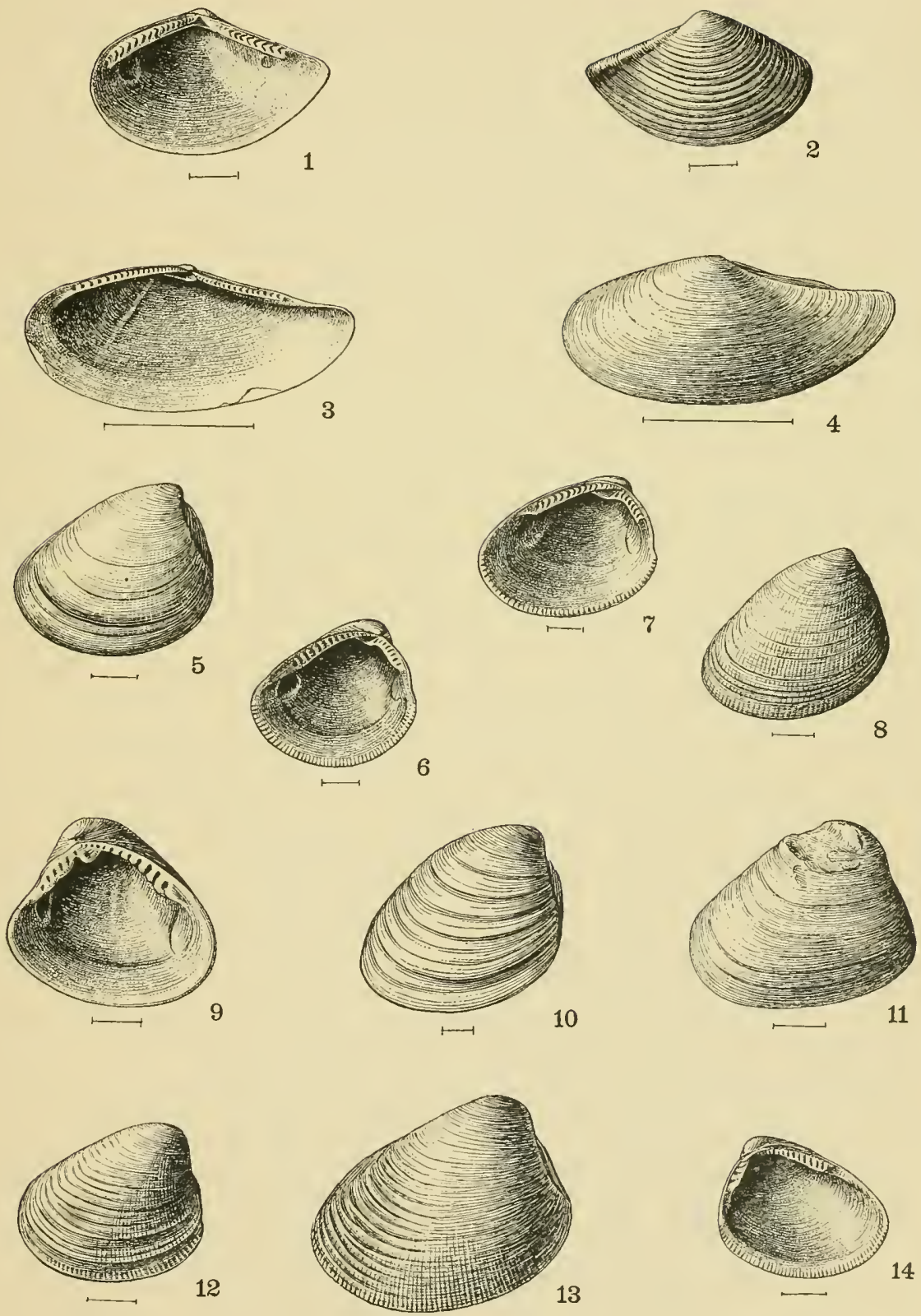

10 
